Prepared in cooperation with the Wyoming Department of Environmental Quality

\title{
Groundwater-Quality Characteristics for the Wyoming Groundwater-Quality Monitoring Network, November 2009 through September 2012
}

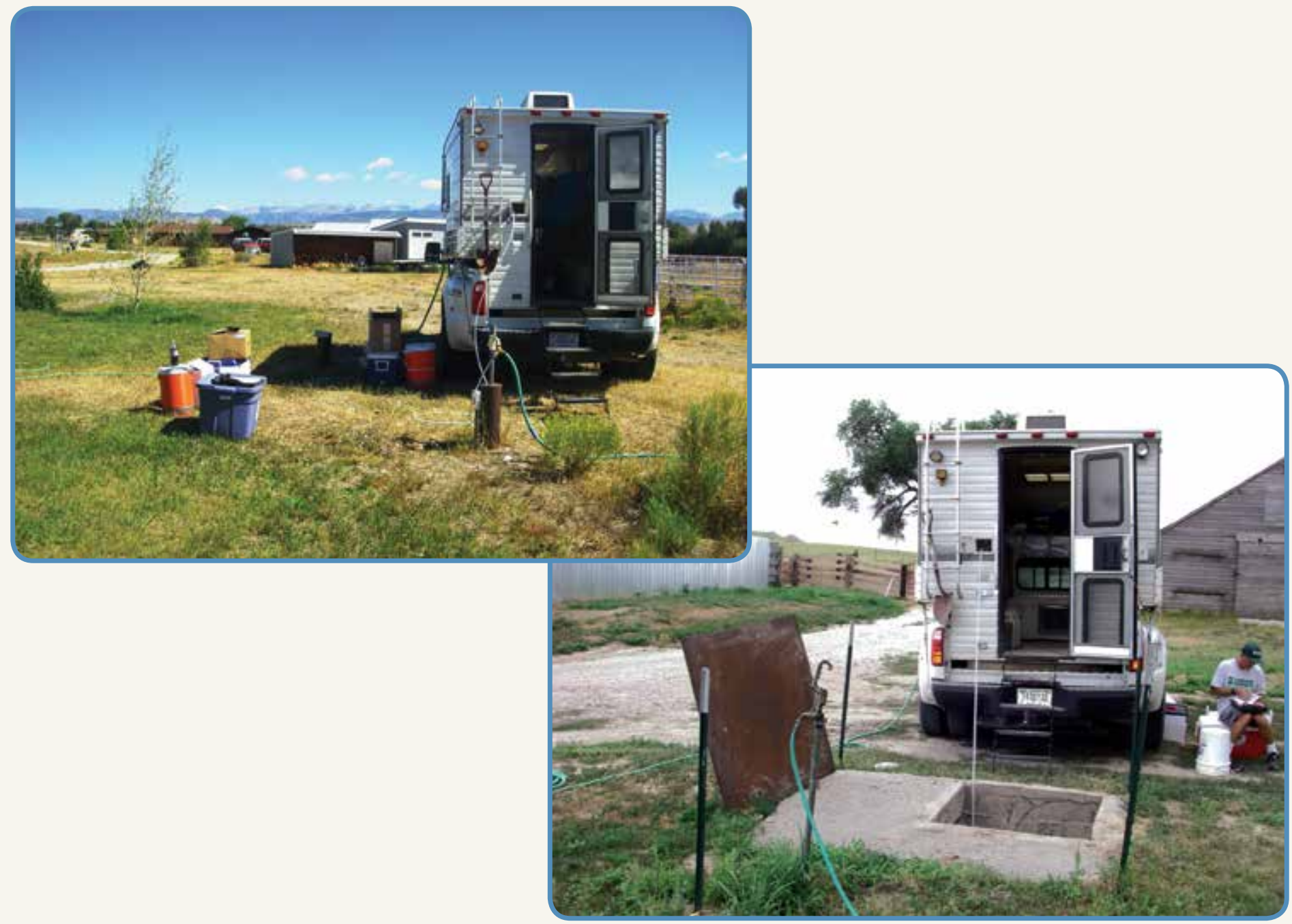

Scientific Investigations Report 2014-5130

Version 1.1, October 2014 


\section{Cover:}

Top, Collecting a groundwater sample from a domestic well in Sublette County, Wyoming, August 17, 2010, taken by Gregory K. Boughton, U.S. Geological Survey.

Bottom, Collecting a groundwater sample from a domestic/stock well in Goshen County, Wyoming, July 26, 2011, taken by Roland Peterson, Wyoming Department of Environmental Quality. 


\section{Groundwater-Quality Characteristics for the Wyoming Groundwater-Quality Monitoring Network, November 2009 through September 2012}

By Gregory K. Boughton

Prepared in cooperation with the Wyoming Department of Environmental Quality

Scientific Investigations Report 2014-5130

Version 1.1, October 2014 


\title{
U.S. Department of the Interior \\ SALLY JEWELL, Secretary
}

\section{U.S. Geological Survey \\ Suzette M. Kimball, Acting Director}

\author{
U.S. Geological Survey, Reston, Virginia: 2014 \\ First release: 2014, online \\ Revised: October 2014 (ver. 1.1)
}

\begin{abstract}
For more information on the USGS - the Federal source for science about the Earth, its natural and living resources, natural hazards, and the environment, visit http://www.usgs.gov or call 1-888-ASK-USGS.

For an overview of USGS information products, including maps, imagery, and publications, visit http://www.usgs.gov/pubprod

To order this and other USGS information products, visit http://store.usgs.gov
\end{abstract}

Any use of trade, firm, or product names is for descriptive purposes only and does not imply endorsement by the U.S. Government.

Although this information product, for the most part, is in the public domain, it also may contain copyrighted materials as noted in the text. Permission to reproduce copyrighted items must be secured from the copyright owner.

Suggested citation:

Boughton, G.K., 2014, Groundwater-quality characteristics for the Wyoming Groundwater-Quality Monitoring Network, November 2009 through September 2012 (ver. 1.1, October 2014): U.S. Geological Survey Scientific Investigations Report 2014-5130, 80 p., appendix, http://dx.doi.org/10.3133/5130.

ISSN 2328-031X (print)

ISSN 2328-0328 (online) 


\section{Acknowledgments}

The author gratefully acknowledges the assistance of landowners who provided access to their property and allowed their wells to be sampled for this study. Also acknowledged for their efforts in supporting this project are Todd Parfitt, John Wagoner, Kevin Frederick, Jane Francis, Adrienne Nunn, Roland Peterson, and Cathy Norris of the Wyoming Department of Environmental Quality; Mike Wireman of the U.S. Environmental Protection Agency; Phil Ogle of the Wyoming Water Development Office; Jim Stafford of the Wyoming State Geological Survey; and Jeremy Manley of the Wyoming State Engineer's Office. The staff at the U.S. Environmental Protection Agency Region VIII laboratory, the U.S. Geological Survey National Water Quality Laboratory, and U.S Geological Survey contract laboratories are acknowledged for analyzing the groundwater samples. 



\section{Contents}

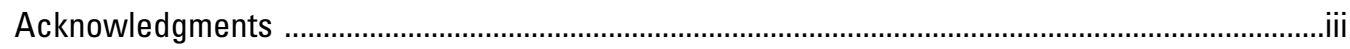

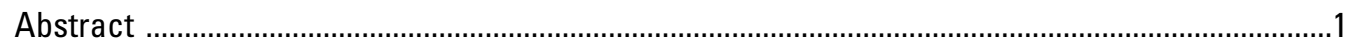

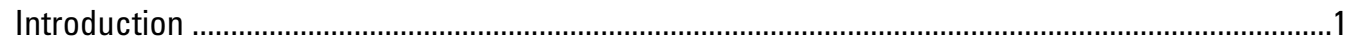

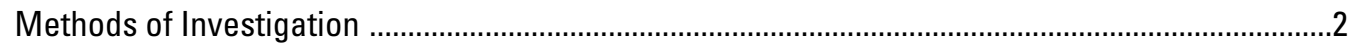

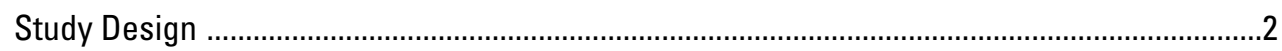

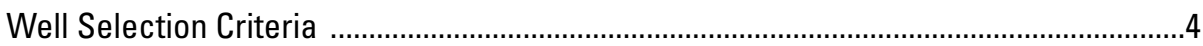

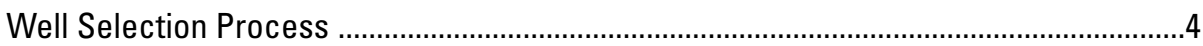

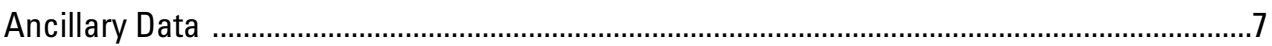

Sample Collection .................................................................................................................

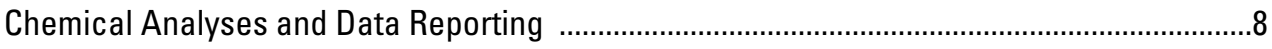

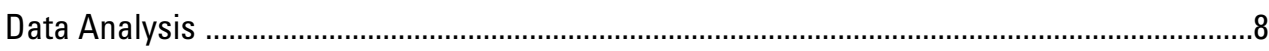

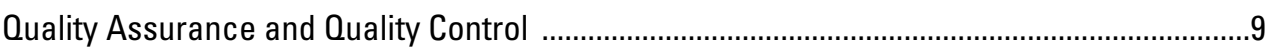

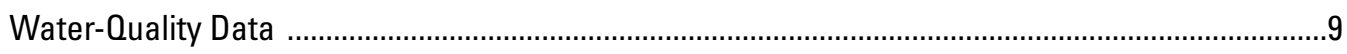

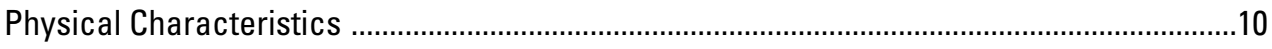

Major lons and Dissolved Solids ....................................................................................13

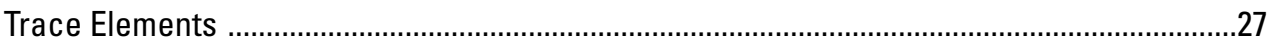

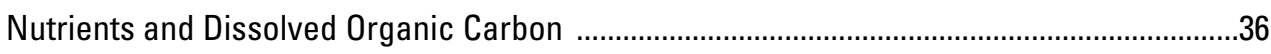

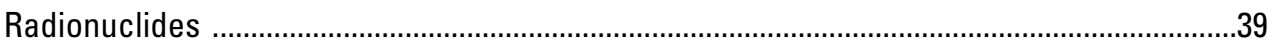

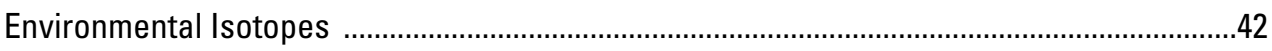

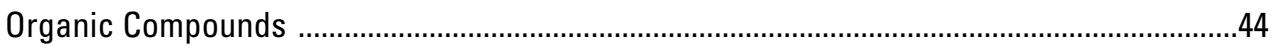

Volatile Organic Compounds .................................................................................4

Gasoline Range and Diesel Range Organics ...........................................................4

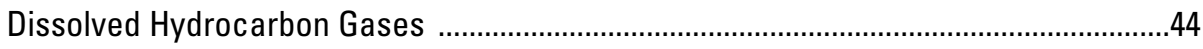

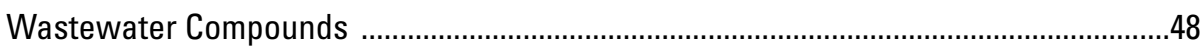

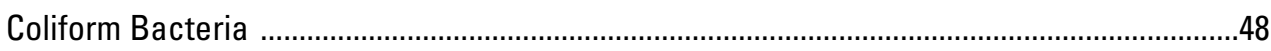

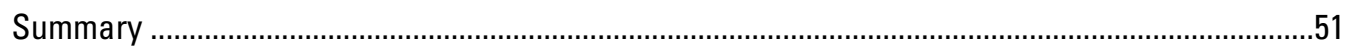

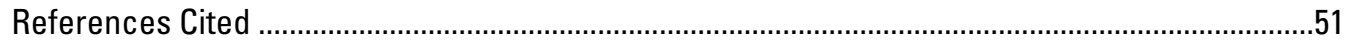

Appendix (available online at http://pubs.usgs.gov/sir/2014/5130/)

\section{Figures}

1. Map showing priority areas of the Wyoming groundwater-quality monitoring

2. Map showing distribution of wells sampled by hydrogeologic unit for the Wyoming groundwater-quality monitoring network, November 2009 through September 2012

3. Map showing values of $\mathrm{pH}$ in groundwater from wells sampled for the Wyoming Groundwater-Quality Monitoring Network, November 2009 through September 2012

4. Map showing values of turbidity in groundwater from wells sampled for the Wyoming Groundwater-Quality Monitoring Network, November 2009 through September 2012 
5. Map showing concentrations of dissolved chloride in groundwater from wells sampled for the Wyoming groundwater-quality monitoring network, November 2009 through September 2012

6. Map showing concentrations of dissolved sulfate in groundwater from wells sampled for the Wyoming groundwater-quality monitoring network, November 2009 through September 2012

7. Map showing concentrations of dissolved fluoride in groundwater from wells sampled for the Wyoming groundwater-quality monitoring network, November 2009 through September 2012

8. Map showing concentrations of dissolved solids in groundwater from wells sampled for the Wyoming groundwater-quality monitoring network, November 2009 through September 2012

9. Trilinear diagram characterizing major-ion chemistry and dissolved solids concentrations for groundwater samples collected from Quaternary unconsolidated-deposit aquifers, Wyoming, November 2009 through September 2012

10. Trilinear diagram characterizing major-ion chemistry and dissolved solids concentrations for groundwater samples collected from wells completed in the Ogallala aquifer in Wyoming, November 2009 through September 2012

11. Trilinear diagram characterizing major-ion chemistry and dissolved solids concentrations for groundwater samples collected from wells completed in the Arikaree aquifer in Wyoming, November 2009 through September 2012

12. Trilinear diagram characterizing major-ion chemistry and dissolved solids concentrations for groundwater samples collected from wells completed in the White River Group (White River, Brule, and Chadron aquifers) in Wyoming, November 2009 through September 2012

13. Trilinear diagram characterizing major-ion chemistry and dissolved solids concentrations for groundwater samples collected from wells completed in the Bridger and Farson Sandstone-Alkali Creek aquifers in Wyoming, November 2009 through September 2012

14. Trilinear diagram characterizing major-ion chemistry and dissolved solids concentrations for groundwater samples collected from wells completed in the Wasatch aquifer in Wyoming, November 2009 through September 2012

15. Trilinear diagram characterizing major-ion chemistry and dissolved solids concentrations for groundwater samples collected from wells completed in the Mesozoic hydrogeologic units (Lance, Sundance, and Nugget aquifers) in Wyoming, November 2009 through September 2012

16. Trilinear diagram characterizing major-ion chemistry and dissolved solids concentrations for groundwater samples collected from wells completed in the Paleozoic hydrogeologic units (Casper and Hartville aquifers) in Wyoming, November 2009 through September 2012

17. Trilinear diagram characterizing major-ion chemistry and dissolved solids concentrations for groundwater samples collected from wells completed in the Precambrian aquifer in Wyoming, November 2009 through September 2012.

18. Map showing concentrations of total aluminum in groundwater from wells sampled for the Wyoming Groundwater-Quality Monitoring Network, November 2009 through September 2012

19. Map showing concentrations of total iron in groundwater from wells sampled for the Wyoming Groundwater-Quality Monitoring Network, November 2009 through September 2012 
20. Map showing concentrations of total manganese in groundwater from wells sampled for the Wyoming Groundwater-Quality Monitoring Network, November 2009 through September 2012

21. Map showing concentrations of total molybdenum in groundwater from wells sampled for the Wyoming Groundwater-Quality Monitoring Network, November 2009 through September 2012

22. Map showing concentrations of total arsenic in groundwater from wells sampled for the Wyoming Groundwater-Quality Monitoring Network, November 2009 through September 2012

23. Map showing concentrations of total boron in groundwater from wells sampled for the Wyoming Groundwater-Quality Monitoring Network, November 2009 through September 2012

24. Map showing concentrations of total selenium in groundwater from wells sampled for the Wyoming Groundwater-Quality Monitoring Network, November 2009 through September 2012

25. Map showing concentrations of dissolved nitrite in groundwater from wells sampled for the Wyoming Groundwater-Quality Monitoring Network, November 2009 through September 2012

26. Map showing concentrations of dissolved nitrate in groundwater from wells sampled for the Wyoming Groundwater-Quality Monitoring Network, November 2009 through September 2012

27. Map showing concentrations of radon in groundwater from wells sampled for the Wyoming Groundwater-Quality Monitoring Network, November 2009 through September 2012

28. Map showing concentrations of total uranium in groundwater from wells sampled for the Wyoming Groundwater-Quality Monitoring Network, November 2009 through September 2012

29. Graph showing relation between oxygen and hydrogen isotopic ratios in groundwater from wells completed in the High Plains aquifer system sampled for the Wyoming Groundwater-Quality Monitoring Network, November 2009 through September 2012

30. Graph showing relation between oxygen and hydrogen isotopic ratios in groundwater from wells not completed in the High Plains aquifer system sampled for the Wyoming Groundwater-Quality Monitoring Network, November 2009 through September 2012

31. Map showing concentrations of gasoline range organics in groundwater from wells sampled for the Wyoming Groundwater-Quality Monitoring Network, November 2009 through September 2012

32. Map showing concentrations of diesel range organics in groundwater from wells sampled for the Wyoming Groundwater-Quality Monitoring Network, November 2009 through September 2012

33. Map showing concentrations of methane in groundwater from wells sampled for the Wyoming Groundwater-Quality Monitoring Network, November 2009 through September 2012

34. Map showing presence of total coliforms in groundwater from wells sampled for the Wyoming Groundwater-Quality Monitoring Network, November 2009 through September 2012

35. Map showing presence of Escherichia coli in groundwater from wells sampled for the Wyoming Groundwater-Quality Monitoring Network, November 2009 through September 2012 


\section{Tables}

1. Priority areas of the Wyoming Groundwater-Quality Monitoring Network

2. Relation of Tertiary, Mesozoic, Paleozoic, and Precambrian lithostratigraphic units to hydrogeologic units, and location and number of groundwater samples collected for the Wyoming Groundwater-Quality Monitoring Network, November 2009 through September 2012

3. Well construction and ancillary data for wells sampled for the Wyoming Groundwater-Quality Monitoring Network, November 2009 through September 2012

4. Wyoming Groundwater-Quality Monitoring Network constituent list, analytical laboratory, analysis method, and method reference

5. Statistical summaries of groundwater-quality characteristics and constituents related to U.S. Environmental Protection Agency and Wyoming Department of Environmental Quality standards for samples from wells in the Wyoming Groundwater-Quality Monitoring Network, November 2009 through September 2012

6. Dissolved-solids concentrations in waters from hydrogeologic units compared to U.S. Geological Survey salinity classification (Heath, 1983) for samples from wells sampled for the Wyoming Groundwater-Quality Monitoring Network, November 2009 through September 2012 


\section{Conversion Factors and Datums}

Inch/Pound to SI

\begin{tabular}{|c|c|c|}
\hline Multiply & By & To obtain \\
\hline \multicolumn{3}{|c|}{ Length } \\
\hline inch (in.) & 2.54 & centimeter (cm) \\
\hline inch (in.) & 25.4 & millimeter (mm) \\
\hline foot (ft) & 0.3048 & meter (m) \\
\hline mile (mi) & 1.609 & kilometer (km) \\
\hline \multicolumn{3}{|c|}{ Area } \\
\hline acre & 0.4047 & hectare (ha) \\
\hline \multicolumn{3}{|c|}{ Flow rate } \\
\hline gallon per minute (gal/min) & 0.06309 & liter per second (L/s) \\
\hline \multicolumn{3}{|c|}{ Radioactivity } \\
\hline picocurie per liter (pCi/L) & 0.037 & becquerel per liter $(\mathrm{Bq} / \mathrm{L})$ \\
\hline
\end{tabular}

SI to Inch/Pound (used for analytical methods)

\begin{tabular}{lcl}
\hline \multicolumn{1}{c}{ Multiply } & \multicolumn{1}{c}{ By } & \multicolumn{1}{c}{ To obtain } \\
\hline micrometer $(\mu \mathrm{m})$ & Length & \\
\hline & 0.00003937 & inch (in.) \\
\hline liter $(\mathrm{L})$ & Volume & \\
milliliter $(\mathrm{mL})$ & 0.2642 & gallon (gal) \\
\hline & 0.03382 & ounce, fluid (fl. oz) \\
\hline milligram per liter $(\mathrm{mg} / \mathrm{L})$ & Concentration & \\
microgram per liter $(\mu \mathrm{g} / \mathrm{L})$ & 1.0 & part per million $(\mathrm{ppm})$ \\
\hline
\end{tabular}

Temperature in degrees Celsius $\left({ }^{\circ} \mathrm{C}\right)$ may be converted to degrees Fahrenheit $\left({ }^{\circ} \mathrm{F}\right)$ as follows:

${ }^{\circ} \mathrm{F}=\left(1.8 x^{\circ} \mathrm{C}\right)+32$

Vertical coordinate information is referenced to the North American Vertical Datum of 1988 (NAVD 88).

Horizontal coordinate information is referenced to the North American Datum of 1983 (NAD 83).

Altitude, as used in this report, refers to distance above the vertical datum.

Specific conductance is given in microsiemens per centimeter at 25 degrees Celsius $(\mu \mathrm{S} / \mathrm{cm}$ at $\left.25^{\circ} \mathrm{C}\right)$

Concentrations of chemical constituents in water are given in milligrams per liter (mg/L) or micrograms per liter $(\mu \mathrm{g} / \mathrm{L})$.

Concentrations of radionuclides in water are given in picocuries per liter ( $\mathrm{pCi} / \mathrm{L})$. 


\title{
Abbreviated Water-Quality Units
}

\author{
colonies/100 mL colonies per 100 milliliters \\ $\delta^{2} \mathrm{H}$ deuterium/protium isotopic ratio \\ $\delta^{18} \mathrm{O} \quad$ oxygen-18/oxygen-16 isotopic ratio \\ $\mathrm{mg} / \mathrm{L} \quad$ milligrams per liter \\ $\mathrm{mV} \quad$ millivolts \\ $\mu \mathrm{g} / \mathrm{L} \quad$ micrograms per liter \\ NTRU nephelometric turbidity ratio units \\ $\mathrm{pCi} / \mathrm{L} \quad$ picocuries per liter
}

\section{Symbols and Abbreviations}

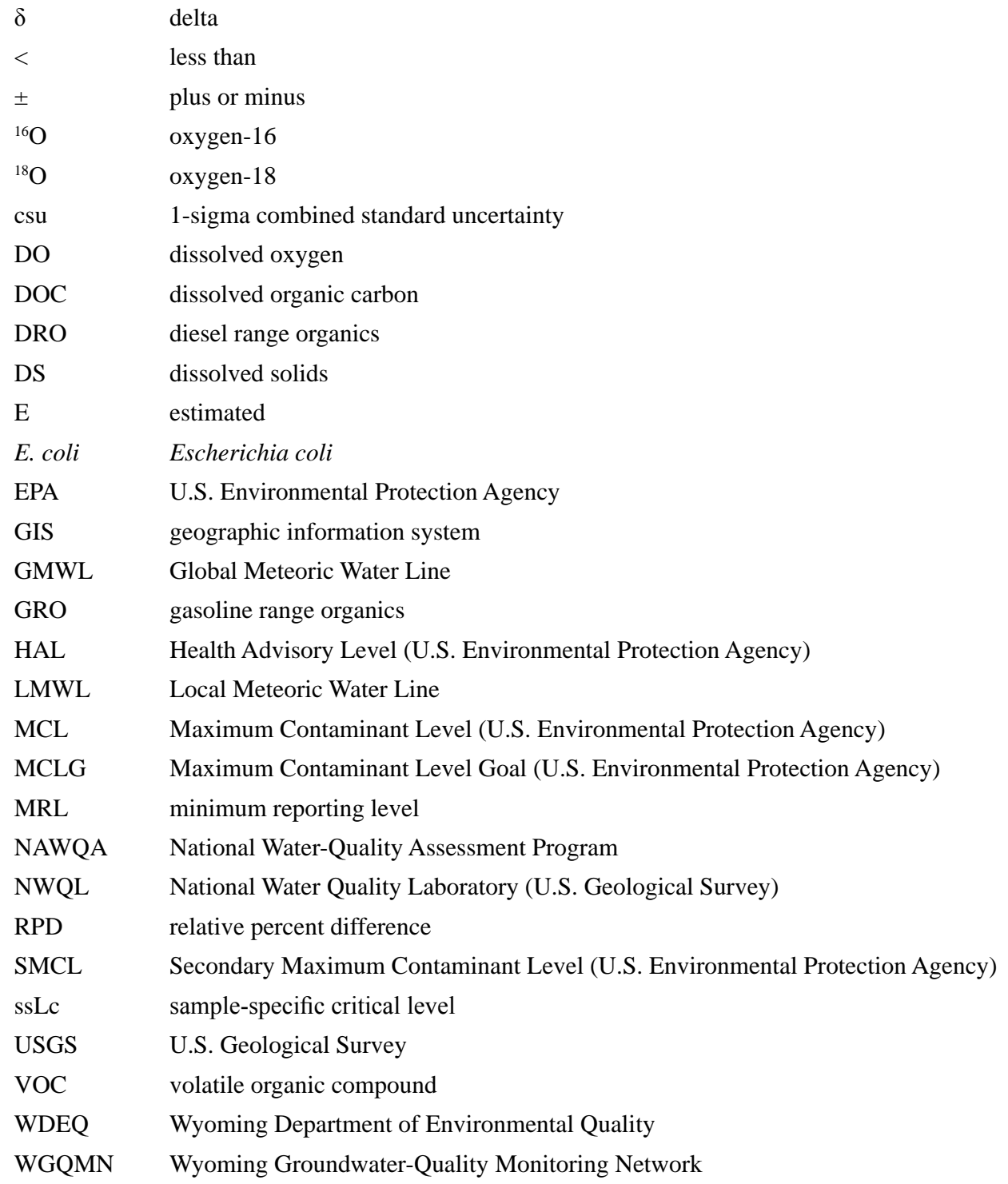




\title{
Groundwater-Quality Characteristics for the Wyoming Groundwater-Quality Monitoring Network, November 2009 through September 2012
}

\author{
By Gregory K. Boughton
}

\section{Abstract}

Groundwater samples were collected from 146 shallow (less than or equal to 500 feet deep) wells for the Wyoming Groundwater-Quality Monitoring Network, from November 2009 through September 2012. Groundwater samples were analyzed for physical characteristics, major ions and dissolved solids, trace elements, nutrients and dissolved organic carbon, uranium, stable isotopes of hydrogen and oxygen, volatile organic compounds, and coliform bacteria. Selected samples also were analyzed for gross alpha radioactivity, gross beta radioactivity, radon, tritium, gasoline range organics, diesel range organics, dissolved hydrocarbon gases (methane, ethene, and ethane), and wastewater compounds.

Water-quality measurements and concentrations in some samples exceeded numerous U.S. Environmental Protection Agency (EPA) drinking water standards. Physical characteristics and constituents that exceeded EPA Maximum Contaminant Levels (MCLs) in some samples were arsenic, selenium, nitrite, nitrate, gross alpha activity, and uranium. Total coliforms and Escherichia coli in some samples exceeded EPA Maximum Contaminant Level Goals. Measurements of $\mathrm{pH}$ and turbidity and concentrations of chloride, sulfate, fluoride, dissolved solids, aluminum, iron, and manganese exceeded EPA Secondary Maximum Contaminant Levels in some samples. Radon concentrations in some samples exceeded the alternative MCL proposed by the EPA. Molybdenum and boron concentrations in some samples exceeded EPA Health Advisory Levels.

Water-quality measurements and concentrations also exceeded numerous Wyoming Department of Environmental Quality (WDEQ) groundwater standards. Physical characteristics and constituents that exceeded WDEQ Class I domestic groundwater standards in some samples were measurements of $\mathrm{pH}$ and concentrations of chloride, sulfate, dissolved solids, iron, manganese, boron, selenium, nitrite, and nitrate. Measurements of $\mathrm{pH}$ and concentrations of chloride, sulfate, dissolved solids, aluminum, iron, manganese, boron, and selenium exceeded WDEQ Class II agriculture groundwater standards in some samples. Measurements of
$\mathrm{pH}$ and concentrations of sulfate, dissolved solids, aluminum, boron, and selenium exceeded WDEQ Class III livestock groundwater standards in some samples. The concentrations of dissolved solids in two samples exceeded the WDEQ Class IV industry groundwater standard. Measurements of $\mathrm{pH}$ and concentrations of dissolved solids, aluminum, iron, manganese, and selenium exceeded WDEQ Class special (A) fish and aquatic life groundwater standards in some samples.

Stable isotopes of hydrogen and oxygen measured in water samples were compared to the Global Meteoric Water Line and Local Meteoric Water Lines. Results indicated that recharge to all of the wells was derived from precipitation and that the water has undergone some fractionation, possibly because of evaporation.

Concentrations of organic compounds did not exceed any State or Federal water-quality standards. Few volatile organic compounds were detected in samples, whereas gasoline range organics, diesel range organics, and methane were detected most frequently.

Concentrations of wastewater compounds did not exceed any State or Federal water-quality standards. The compounds $N, N$-diethyl-meta-toluamide (DEET), benzophenone, and phenanthrene were detected most frequently.

Bacteria samples were collected, processed, incubated, and enumerated in the field or at the U.S. Geological Survey Wyoming-Montana Water Science Center. Total coliforms and Escherichia coli were detected in some samples.

\section{Introduction}

About 80 percent of Wyoming's population depends on groundwater for drinking water, including 17 percent that are self-supplied (Kenny and others, 2009). In many areas, groundwater is the only viable source of water because surface water is not present or is unsuitable for use. Shallow (less than or equal to 500 feet deep) aquifers supply water for most rural households and also commonly are used for stock, irrigation, and industrial use (Kenny and others, 2009). 
Groundwater management in Wyoming is focused on the protection of groundwater, with particular attention to shallow aquifers. These aquifers are the most susceptible to water-quality degradation from human activities (Bedessem and others, 2003). In general, groundwater in Wyoming is of high quality (U.S. Environmental Protection Agency, 2004a); however, increased human activities and changing land-use patterns create the potential for water-quality degradation. Sources of pollution include point sources, which have identifiable discharges, and nonpoint sources, which are more diffuse. Nonpoint sources of contaminants include runoff from agricultural lands, erosion from resource extraction and construction activities, and fallout or deposition from the atmosphere (Rubin and Davidson, 2001).

Groundwater protection remains an objective of the Wyoming Department of Environmental Quality (WDEQ) through their Wyoming Nonpoint Source Program (Wyoming Department of Environmental Quality, 2012). The program emphasizes the importance of statewide groundwater monitoring, which includes expanding the monitoring network into additional areas of the State (Jennifer Zygmunt, Wyoming Department of Environmental Quality, written commun., 2012).

A wide variety of human activities has the potential to contaminate groundwater. In addition, naturally occurring constituents can limit the suitability of groundwater for some uses. Baseline groundwater-quality data can be used to facilitate analysis of water-quality trends over time and to understand effects from human activities. Such information can be a resource used by stakeholders to protect groundwater resources that are critical for drinking water and other uses.

The Wyoming Groundwater-Quality Monitoring Network (WGQMN) is a cooperative program between the U.S. Geological Survey (USGS) and the WDEQ. The WGQMN program was established in 2009 to evaluate current baseline water-quality characteristics of Wyoming's groundwater. Representatives from USGS, WDEQ, the U.S. Environmental Protection Agency (EPA), the Wyoming Water Development Office, the Wyoming State Geological Survey, and the Wyoming State Engineer's Office formed a steering committee that meets periodically to evaluate progress and consider modifications to strengthen program objectives. Given the resources required to complete a baseline assessment of groundwater quality for the State, monitoring will be an ongoing effort for several years. Areas to be sampled are determined by the steering committee based on current and likely future land uses. The purpose of this report is to describe groundwater quality using samples collected as part of the WGQMN from November 2009 through September 2012. The scope includes general statistical summaries for water-quality constituents and comparisons of sampling results to water-quality standards and guidelines.

\section{Methods of Investigation}

This section of the report describes the methods used for the study design, collection of ancillary data, sample collection, chemical analyses and data reporting, data analysis, and quality assurance and quality control.

\section{Study Design}

A group of State agencies evaluated the sensitivity of Wyoming's groundwater aquifers to pesticide contamination based on aquifer and surface characteristics that affect the transport of potential contaminants from the ground surface into an aquifer. Characteristics used for the study included depth to groundwater, aquifer recharge, geohydrologic setting, soils, land-surface slope, and vadose zone setting. Results of this evaluation were used to identify high priority aquifers in the State. High priority aquifers are those aquifers that are drinking water sources and are considered most susceptible to nonpoint and point pollution (Bedessem and others, 2003). A group of State agencies identified and characterized priority areas to focus resources, monitoring, and education for groundwater protection statewide.

The study design is based on moderate-high and high priority areas for groundwater in Wyoming. Priority areas were combined based on similar aquifer type and location. Priority areas less than 10,000 acres were included only if they were near communities with populations greater than 2,000. Based on these criteria, 33 priority areas were identified (fig. 1, table 1) and grouped by major river basin (Bedessem and others, 2003). The statement of work calls for groundwater samples to be collected from 20 to 30 existing wells within each priority area, for a total of between 660 and 990 wells (Boughton, 2011). The study design limited sampling to shallow groundwater, which was defined to include wells less than or equal to 500 feet (ft) deep. Wells selected for sampling were completed in Quaternary-age unconsolidated-deposit aquifers and bedrock aquifers. From November 2009 through September 2012, the program consisted of sampling groundwater wells within moderatehigh and high priority areas in Albany, Carbon, Goshen, Laramie, Platte, Sublette, Sweetwater, and Uinta Counties (fig. 2).

Aquifers in unconsolidated deposits of Quaternary age (alluvium and terrace deposits) are collectively referred to herein as Quaternary unconsolidated-deposit aquifers, and the Tertiary, Mesozoic, Paleozoic, and Precambrian hydrogeologic units are the bedrock aquifers (table 2). 


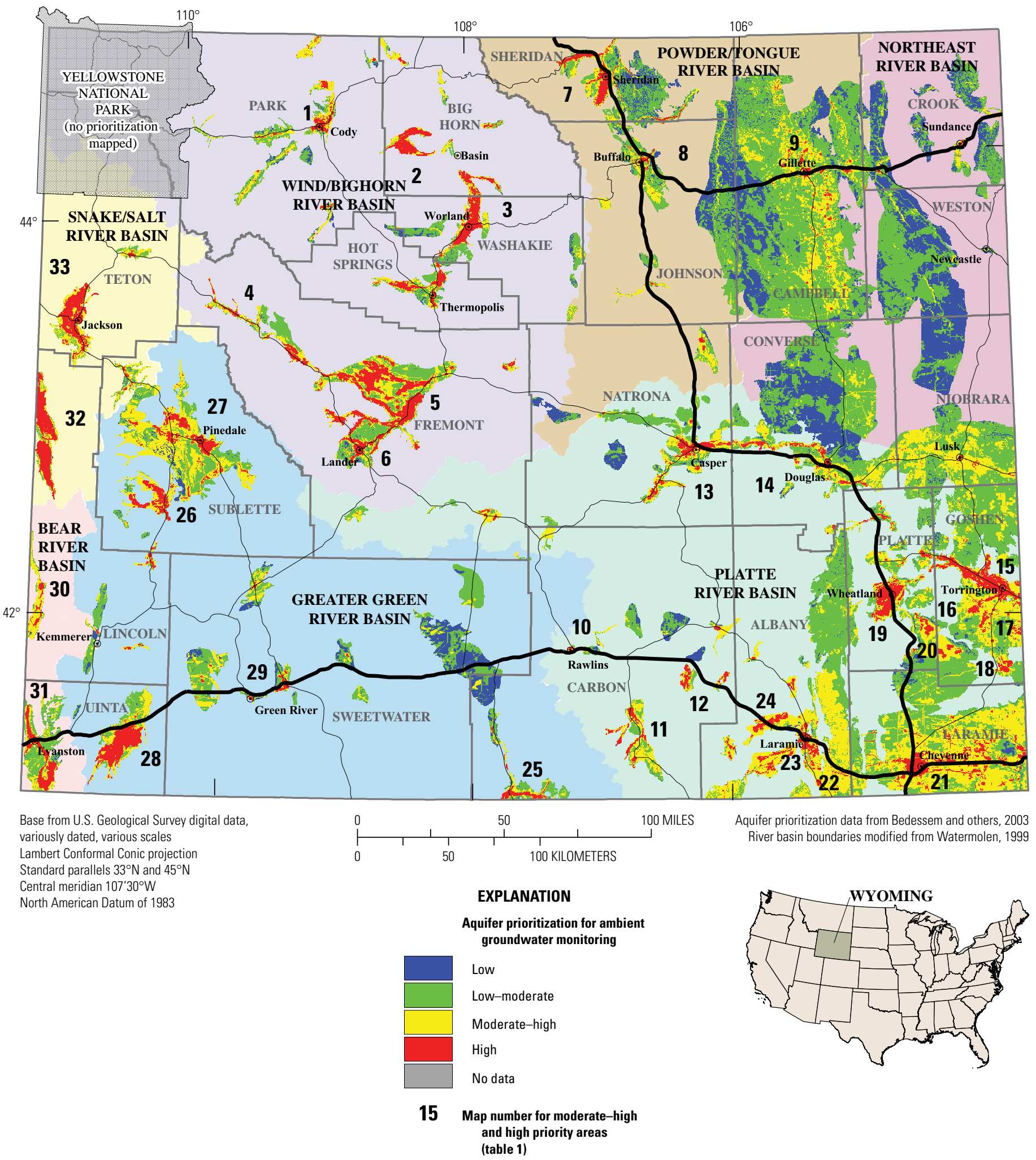

Figure 1. Priority areas of the Wyoming groundwater-quality monitoring network. 
Table 1. Priority areas of the Wyoming Groundwater-Quality Monitoring Network.

\begin{tabular}{|c|c|c|}
\hline $\begin{array}{l}\text { Priority } \\
\text { area } \\
\text { number } \\
\text { shown } \\
\text { on } \\
\text { figure } 1\end{array}$ & $\begin{array}{c}\text { Priority } \\
\text { area }\end{array}$ & $\begin{array}{l}\text { River } \\
\text { basin }\end{array}$ \\
\hline 1 & Cody/Wapiti & Wind/Bighorn \\
\hline 2 & Emblem & Wind/Bighorn \\
\hline 3 & Thermopolis/Big Horn River/Worland & Wind/Bighorn \\
\hline 4 & Dubois/Crowheart & Wind/Bighorn \\
\hline 5 & Riverton/Wind River & Wind/Bighorn \\
\hline 6 & Lander/Hudson & Wind/Bighorn \\
\hline 7 & Sheridan/Dayton & Powder/Tongue \\
\hline 8 & Buffalo & Powder/Tongue \\
\hline 9 & Gillette/Rozet & Powder/Tongue \\
\hline 10 & Rawlins & Platte \\
\hline 11 & Saratoga & Platte \\
\hline 12 & Elk Mountain & Platte \\
\hline 13 & Casper/Evansville/Alcova & Platte \\
\hline 14 & Glenrock/Douglas/Orin & Platte \\
\hline 15 & Torrington & Platte \\
\hline 16 & Yoder/Veteran & Platte \\
\hline 17 & Huntley and by border & Platte \\
\hline 18 & LaGrange/Hawk Springs & Platte \\
\hline 19 & Wheatland & Platte \\
\hline 20 & Slater/Chugwater & Platte \\
\hline 21 & Cheyenne & Platte \\
\hline 22 & Laramie/Tie Siding & Platte \\
\hline 23 & Laramie River & Platte \\
\hline 24 & Little Laramie River & Platte \\
\hline 25 & Baggs & Greater Green \\
\hline 26 & Big Piney/Marbleton & Greater Green \\
\hline 27 & Pinedale/Boulder/Daniel & Greater Green \\
\hline 28 & Mountain View & Greater Green \\
\hline 29 & Rock Springs & Greater Green \\
\hline 30 & Cokeville/Bear River & Bear \\
\hline 31 & Evanston/Bear River & Bear \\
\hline 32 & Star Valley & Bear \\
\hline 33 & Jackson/Teton Village & Snake/Salt \\
\hline
\end{tabular}

\section{Well Selection Criteria}

As many of the following well selection criteria were met as possible:

- The well is accessible to vehicles.

- The well has been assigned a Wyoming State Engineer's Office permit number.

- For wells with existing pumps, only those with submersible pumps are selected.

- The well construction and pumping equipment in the well are known to be of types that are not likely to affect the water-quality constituents of concern. Well-casing material of threaded polyvinyl chloride or stainless steel is preferred. Wells with water-lubricated pumps are selected in preference to wells with oil-lubricated pumps. The well is drilled (rather than dug, bored, or driven). The well is properly sealed at the surface.

- Monitoring and observation wells previously installed to detect a known or suspected contaminant are to be avoided. Monitoring wells upgradient from known contamination are acceptable.

- Wells located immediately next to roads are avoided because of the common use of herbicides and road-salt applications along roadsides. Where this is not possible, knowledge about roadside application of chemicals is documented.

- Access for a water-level measurement is possible.

- The well can be pumped at a rate that is adequate for sampling, typically on the order of at least 1 gallon per minute, for several hours.

- The sampling point should be located before any water treatment, pressure tanks, or holding tanks.

\section{Well Selection Process}

Wells were classified by their relative depths, which vary by priority area. Using a histogram of the depth of all wells in a priority area, shallow, moderately deep, and deep well classes were chosen from natural breaks in the histogram. This provided information on the depths that were considered shallow, moderately deep, and deep, as well as what percentage of the wells were in each category. These well depth distributions were used as a guideline for final well selection. Geographic information system (GIS) shape files were generated for the shallow, moderately deep, and deep wells and overlain on the priority areas. WDEQ personnel selected wells from each shape file to give full coverage of the priority area to be sampled. USGS personnel located Wyoming State Engineer's Office groundwater well permits for selected wells and well owners were contacted to obtain permission to collect a groundwater sample. If a selected well could not be sampled, permission was obtained for a nearby well and selected for sampling. 


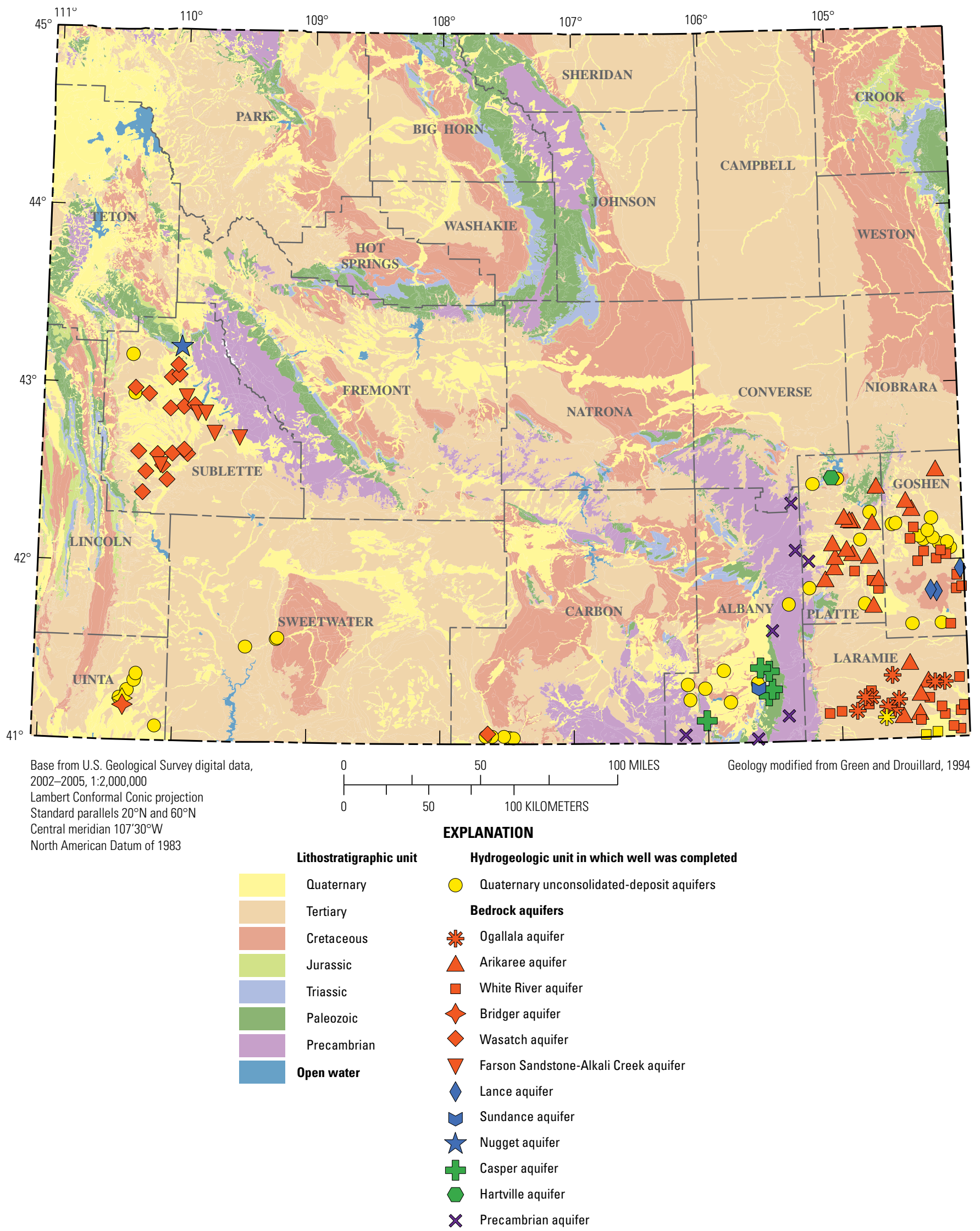

Figure 2. Distribution of wells sampled by hydrogeologic unit for the Wyoming groundwater-quality monitoring network, November 2009 through September 2012. 
Table 2. Relation of Tertiary, Mesozoic, Paleozoic, and Precambrian lithostratigraphic units to hydrogeologic units, and location and number of groundwater samples collected for the Wyoming Groundwater-Quality Monitoring Network, November 2009 through September 2012.

\begin{tabular}{|c|c|c|c|c|}
\hline Lithostratigraphic unit & $\begin{array}{l}\text { Age of } \\
\text { lithostratigraphic unit } \\
\text { (Love and others, 1993) }\end{array}$ & Hydrogeologic unit & $\begin{array}{l}\text { Reference(s) for } \\
\text { hydrogeologic unit definition }\end{array}$ & $\begin{array}{l}\text { Counties where } \\
\text { hydrogeologic unit } \\
\text { was sampled } \\
\text { (number of samples } \\
\text { collected) }\end{array}$ \\
\hline \multicolumn{5}{|c|}{ Tertiary hydrogeologic units } \\
\hline Ogallala Formation & Miocene & $\begin{array}{l}\text { Ogallala aquifer (High } \\
\text { Plains aquifer system) }\end{array}$ & Bartos and Hallberg (2011, fig. 2) & Laramie (10) \\
\hline Arikaree Formation & Miocene and Oligocene & $\begin{array}{l}\text { Arikaree aquifer (High } \\
\text { Plains aquifer system) }\end{array}$ & Bartos and Hallberg (2011, fig. 2) & $\begin{array}{l}\text { Laramie (5); Goshen (3); } \\
\quad \text { Platte (14) }\end{array}$ \\
\hline $\begin{array}{l}\text { White River Group or Formation (includes } \\
\text { Brule and Chadron Formations where "White } \\
\text { River" is elevated to group rank) }\end{array}$ & Oligocene & $\begin{array}{l}\text { White River aquifer (High } \\
\text { Plains aquifer system) }\end{array}$ & Bartos and Hallberg (2011, fig. 2) & $\begin{array}{l}\text { Laramie (15), Goshen } \\
\text { (11), Platte (3) }\end{array}$ \\
\hline Bridger Formation & Eocene & Bridger aquifer & $\begin{array}{l}\text { Martin (1996); Glover and others (1998); } \\
\text { Bartos and Hallberg (2010, figs. 5-1 and } \\
\text { 5-2) }\end{array}$ & Uinta (2) \\
\hline Wasatch Formation & Eocene & $\begin{array}{l}\text { Wasatch zone of the } \\
\text { Wasatch-Fort Union } \\
\text { aquifer (Wasatch aquifer) }\end{array}$ & $\begin{array}{l}\text { Martin (1996); Glover and others (1998); } \\
\text { Bartos and Hallberg (2010, figs. 5-1 and } \\
\text { 5-2) }\end{array}$ & Sublette (17), Carbon (1) \\
\hline Alkali Creek Tongue of the Wasatch Formation & Eocene & $\begin{array}{l}\text { Farson Sandstone-Alkali } \\
\text { Creek aquifer }\end{array}$ & $\begin{array}{l}\text { Martin (1996); Glover and others (1998); } \\
\text { Bartos and Hallberg (2010, figs. 5-1 and } \\
\text { 5-2) }\end{array}$ & Sublette (1) \\
\hline $\begin{array}{l}\text { Farson Sandstone Member of the Green River } \\
\text { Formation }\end{array}$ & Eocene & $\begin{array}{l}\text { Farson Sandstone-Alkali } \\
\text { Creek aquifer }\end{array}$ & $\begin{array}{l}\text { Martin (1996); Glover and others (1998); } \\
\text { Bartos and Hallberg (2010, figs. 5-1 and } \\
\text { 5-2) }\end{array}$ & Sublette (5) \\
\hline \multicolumn{5}{|c|}{ Mesozoic hydrogeologic units } \\
\hline Lance Formation & Late Cretaceous & Lance aquifer & Libra and others (1981, fig. II-5) & Goshen (3) \\
\hline Sundance Formation & Jurassic & Sundance aquifer & Libra and others (1981, fig. II-5) & Albany (1) \\
\hline Nugget Sandstone & Jurassic (?) and Triassic (?) & Nugget aquifer & Bartos and Hallberg (2010, fig. 5-3) & Sublette (1) \\
\hline \multicolumn{5}{|c|}{ Paleozoic and Precambrian hydrogeologic units } \\
\hline "Converse sand" of the Hartville Formation & $\begin{array}{l}\text { Permian, Pennsylvanian, } \\
\text { and Mississippian }\end{array}$ & Hartville aquifer & $\begin{array}{l}\text { Libra and others (1981, fig. II-5 and table } \\
\text { IV-1) }\end{array}$ & Platte (1) \\
\hline Casper and Fountain Formations & $\begin{array}{l}\text { Permian and Pennsylvanian } \\
\text { (Casper Formation); } \\
\text { Pennsylvanian (Fountain } \\
\text { Formation) }\end{array}$ & Casper aquifer & $\begin{array}{l}\text { Lundy (1978); Libra and others (1981, fig. } \\
\text { II-5 and table IV-1) }\end{array}$ & Albany (5) \\
\hline Undifferentiated Precambrian rocks & Precambrian & Precambrian aquifer & Libra and others (1981, fig. II-5) & Albany (6); Platte (1) \\
\hline
\end{tabular}




\section{Ancillary Data}

Ancillary data were collected for all wells and were designed in part to document activities that might affect shallow groundwater quality (table 3 at end of report). Well permits were obtained from the Wyoming State Engineers' Office (http://seoweb.wyo.gov/e-Permit/common/login. aspx?ReturnUrl=/e-Permit/Default.aspx). Landowners were contacted to obtain permission to collect a sample, to verify the location and condition of the well, to acquire current contact information, and to inquire about possible sources of groundwater contamination. Field-grade global-positioning system coordinates, using the North American Datum of 1983 for latitude and longitude, and the North American Vertical Datum of 1988 for altitude, were recorded at the well head. A land-use/land-cover field sheet was used to document land use and land cover within $100 \mathrm{ft}$ and within $1 / 4$ mile of the well. Agricultural practices were documented, including type, extent, and source of irrigation; pesticide and fertilizer application; and crop and animal types. Digital photographs were collected of the wellhead and the sampling location in the four cardinal directions surrounding the well, as well as other features that could affect groundwater quality. A site sketch was drawn of the wellhead and surrounding area.

Water levels were measured whenever possible before water-quality samples were collected from wells. The water level below land surface was measured using a chalked steel tape or an electrical tape, and the measurement was repeated until two consecutive measurements differed by no more than $0.02 \mathrm{ft}$, or until the reason for less precise measurements was determined and documented (Cunningham and Schalk, 2011). In addition, the depth from land surface to the bottom of the well was measured during each site visit whenever possible to verify the integrity of the well construction and to verify the accuracy of well-completion information. For some sites, well caps did not have access points for measuring a water level. In these cases, the water level measured at the time of well construction, if available, is reported in the ancillary data table (table 3).

\section{Sample Collection}

Groundwater samples were collected using standard methods described in the National Field Manual for the Collection of Water-Quality Data (U.S. Geological Survey, variously dated). Water was pumped into a mobile waterquality laboratory and routed through a sampling manifold and flow-through chamber. Physical characteristics (water temperature, $\mathrm{pH}$, specific conductance, dissolved oxygen, and oxidation reduction potential) were monitored in a flow-through chamber during the well purge. Turbidity was measured at the outlet of the flow-through chamber. Physical characteristics, pumping rates, purge volumes, and other pertinent information were recorded on groundwater site forms. After the physical characteristics stabilized and three well-casing volumes were purged, water was diverted to a sampling chamber consisting of a polyvinyl chloride frame enclosed in a plastic bag to minimize the potential of atmospheric contamination. All materials in contact with the water after being pumped out of the wells and before sample collection were either stainless steel or Teflon ${ }^{\circledR}$. All sample bottles were labeled with the site identification number, the date and time of sample collection, bottle type, and the requested laboratory analysis before sample collection.

Different types of samples, analytical methods, and the laboratories that analyzed the samples are listed in table 4 at end of report. Samples to determine alkalinity, dissolved solids (DS), and dissolved organic carbon (DOC) and samples to determine dissolved concentrations of major ions, trace elements, nutrients, gross alpha radioactivity, and gross beta radioactivity were filtered onsite using a 0.45 -micrometer $(\mu \mathrm{m})$ pore-size, disposable disc or capsule filter. Samples to determine total concentrations of major ions, trace elements, nutrients, stable isotopes of hydrogen and oxygen, radon, and tritium were not filtered. Alkalinity, major ions, trace elements, nutrients, stable isotopes of hydrogen and oxygen, and tritium samples were collected in precleaned plastic bottles. The DOC samples were collected in precleaned and baked amber-colored glass bottles. Samples analyzed for trace elements were preserved to a $\mathrm{pH}$ of less than 2 standard units using ultrapure nitric acid. Samples analyzed for nutrients and DOC were preserved to a $\mathrm{pH}$ of less than 2 standard units using 4.5 normal sulfuric acid. Nutrient samples were immediately placed on dry ice to remain frozen until analysis.

Whole-water samples for volatile organic compounds (VOCs) and gasoline range organics (GRO) were collected in three precleaned 40-milliliter $(\mathrm{mL})$ glass vials with septa. The vials were filled with no headspace. Whole-water samples for diesel range organics (DRO) were collected in 1-liter amber glass bottles. The VOC, GRO, and DRO samples were preserved to a $\mathrm{pH}$ of less than 2 standard units using ultrapure hydrochloric acid.

Wastewater compound samples were filtered using a methanol-rinsed stainless-steel filter chamber that contained a baked $0.70-\mu \mathrm{m}$ pore size glass-fiber filter and were collected in precleaned amber-colored glass bottles.

Samples for radon were collected using a glass syringe to withdraw $10 \mathrm{~mL}$ of water from a back pressure valve attached to the sampling manifold. The sample was injected into a glass scintillation vial below a layer of mineral oil and shipped separately to the laboratory by overnight carrier to ensure the 48-hour holding time was met.

Alkalinity was determined in the field by incremental titration of a filtered water sample with sulfuric acid (U.S. Geological Survey, variously dated). Bacteria samples (total coliform and Escherichia coli) were collected, processed onto $\mathrm{m}$-Coliblue ${ }^{\odot}$ bacteria plates, incubated, and enumerated in the field or in the USGS Wyoming-Montana Water Science Center laboratory in Cheyenne, Wyoming. 


\section{Chemical Analyses and Data Reporting}

Samples were shipped overnight by commercial carrier to analytical laboratories in sealed ice-filled coolers. Samples were analyzed by the EPA Region VIII Laboratory, USGS National Water Quality Laboratory (NWQL), and USGS contract laboratories. Since the beginning of this study, the list of constituents has been slightly modified because of changes implemented by the steering committee, changes in laboratories performing specific analyses, or problems that occurred during sample processing or analysis. Groundwater samples typically were analyzed for major ions and DS, trace elements, nutrients and DOC, uranium, stable isotopes of hydrogen and oxygen, VOCs, and coliform bacteria (table 4). Selected samples also were analyzed for gross alpha and gross beta radioactivity, radon, tritium, GRO, DRO, dissolved hydrocarbon gases (methane, ethene, and ethane), and wastewater compounds.

Several laboratories were used to complete the variety of analyses needed for the WGQMN study design. Major ions, trace elements, nutrients, and VOC analyses were performed at either the EPA Region VIII laboratory in Golden, Colorado or the USGS NWQL in Denver, Colo. Samples for trace elements (total and dissolved) were analyzed at the EPA Region VIII laboratory starting in June 2010. Analyses for DS, DOC, radon, and wastewater compounds were performed at USGS NWQL. The USGS Reston Stable Isotope Laboratory in Reston, Virginia, analyzed samples for stable isotopes of hydrogen $\left(\delta^{2} \mathrm{H}\right.$ or deuterium/protium isotopic ratio) and oxygen $\left[\left(\delta^{18} \mathrm{O}\right)\right.$ or oxygen-18/oxygen-16 $\left({ }^{18} \mathrm{O} /{ }^{16} \mathrm{O}\right.$ isotopic ratio)]. Some replicate alkalinity samples were sent to USGS NWQL for comparison to measurements made in the field. The USGS Isotope Tracers Project Laboratory in Menlo Park, California, analyzed samples for tritium. Eberline Services in Richmond, Calif. analyzed samples for gross alpha radioactivity and gross beta radioactivity. The VOC analyses were performed at USGS NWQL from November 2009 through December 2009 and at EPA Region VIII Laboratory from June 2010 through September 2012. Analyses of GRO and DRO were performed at TestAmerica Laboratory in Denver, Colo., from November 2009 through December 2010 and at EPA Region VIII Laboratory from May 2011 through September 2012. TestAmerica Laboratory analyzed dissolved hydrocarbon gases samples. Laboratory analytical results for most constituents were reported relative to minimum reporting levels (MRLs). The MRLs are the minimum concentrations of a constituent that can be reported reliably using a given analytical method (Timme, 1995).

Some analytical results are reported as estimated (E) concentrations. Estimated concentrations typically occur when concentrations are less than laboratory reporting levels, but are greater than method detection levels (Childress and others, 1999). Sample conditions, such as matrix interference, also can result in estimated concentrations. For coliform bacteria, when counts are outside the ideal range for the method, results also are reported as estimated.

\section{Data Analysis}

Data analysis for this report included summary statistics for selected constituents and comparisons to groundwater standards and guidelines. Summary statistics presented are minimum, 25th percentile, 50th percentile (median), 75th percentile, and maximum values. For water-quality constituents that rarely or never occurred with censored values (less than reporting levels), such as physical characteristics and major ions, standard data distributions were used for summary statistics. For other constituents, such as trace elements, concentrations frequently are reported as less than laboratory reporting levels. In some cases, censored values were reported with multiple reporting levels. Rather than assigning the laboratory reporting level or another arbitrary level to the values, a log-probability regression procedure was used to compute summary statistics (Dupré and others, 2013). The log-probability regression procedure computes statistics for the interquartile range (25th percentile, median, and 75th percentile). For some constituents, too many censored values were reported for the log-probability regression procedure to compute an interquartile range. In those cases, only minimum and maximum values are presented.

Groundwater samples collected for the WGQMN were compared to EPA standards and other guidelines to assess magnitudes of concentrations (U.S. Environmental Protection Agency, 2012c) (table 5 at end of report). The EPA Maximum Contaminant Levels (MCLs) are legally enforceable standards for public water systems that provide water for human consumption through at least 15 service connections, or that regularly serve at least 25 individuals. The EPA Maximum Contaminant Level Goals (MCLGs) are non-enforceable guidelines based on best available science to prevent potential health problems. The EPA Secondary Maximum Contaminant Levels (SMCLs) are non-enforceable guidelines based on aesthetic qualities of water including taste, odor, and staining properties. The EPA Health Advisory Levels (HALs) are based on concentrations of chemicals that are expected to cause adverse or carcinogenic effects over a lifetime of exposure, are not legally enforceable Federal standards, and serve as technical guidance to assist Federal, State, and local officials.

Groundwater samples collected for the WGQMN also were compared to State of Wyoming groundwater-quality standards (Wyoming Department of Environmental Quality, 2005) (table 5). Groundwaters of the State are classified by use and by ambient water quality, to apply standards to protect water quality. The State, through rule making by the WDEQ, has established a separate set of legally enforceable quality standards for groundwater based on suitability for specific uses. These include groundwater standards for WDEQ Class I waters (domestic use), WDEQ Class II waters (agricultural use), WDEQ Class III waters (livestock use), WDEQ Class IV waters (industrial use), and WDEQ Class Special (A) waters (fish and aquatic life uses). 
Groundwater samples collected for the WGQMN also were compared to median concentrations measured in groundwater samples collected for the USGS National Water-Quality Assessment Program (NAWQA) program from 1992-2003. The NAWQA Program has collected trace element, nutrient, radionuclide, and VOC samples across the United States (Ayotte and others, 2011) to describe baseline groundwater quality.

\section{Quality Assurance and Quality Control}

Quality-assurance procedures were performed in accordance with USGS methods outlined in the National Field Manual for the Collection of Water-Quality Data (U.S. Geological Survey, variously dated). Field equipment was calibrated before each field trip following procedures outlined by the manufacturer. Parts-per-billion collection protocols were used for equipment cleaning and handling, sample and blank collection, and field-processing procedures to minimize contamination and bias. Quality-control samples were collected as part of a quality-assurance program. Quality-control samples are critical in evaluating the procedures and protocols used during sampling, and provide confirmatory information concerning concentration values for target constituents. Quality-control samples were collected, preserved, and analyzed using the same methods and equipment used for environmental samples. Quality-control samples included blank samples (equipment and field) and replicate samples. Constituents with qualified concentrations are presented in table $1-1$.

The purpose of blank samples is to test for sample contamination during various stages of sample collection, processing, shipping, and analysis. Blank samples are collected by processing laboratory-certified blank water through the sampling equipment using the same techniques as used to collect environmental samples in the field. Inorganic-free and organic-free blank water certified to be free of inorganic and organic constituents was obtained from the USGS NWQL. Equipment blanks were processed at the USGS Wyoming-Montana Water Science Center laboratory in Cheyenne, Wyoming, before equipment was taken to the field to verify that the sampling equipment was clean. Field blanks were collected in the field to determine if cleaning procedures removed constituents from sampling equipment between sites and if sampling and laboratory methods were appropriate to prevent contamination of environmental samples (Mueller and others, 1997). In accordance with EPA guidance (U.S. Environmental Protection Agency, 1989, p. 5-17), a reported concentration in an environmental sample that is less than five times the concentration in a related blank sample should be qualified. Eleven constituents (dissolved chloride, dissolved chromium, dissolved cobalt, total cobalt, dissolved copper, total copper, dissolved nitrate, gasoline range organics, methane, trichloromethane, and phenanthrene) were detected in blank samples resulting in qualification of groundwater-sample results. Data that have been qualified according to EPA guidance because of detections in blank samples are identified with a footnote on the primary environmental sample in tables $1-1,1-3,1-4,1-5,1-7$, and $1-8$.

Replicate samples were collected immediately after environmental samples to measure the variability of field and laboratory procedures. The analytical accuracy between the environmental and replicate samples was computed as the relative percent difference (RPD) of constituent concentrations by using the following equation:

$$
\left.R P D=\left[\left(C_{1}-C_{2}\right) /\left(\left(C_{1}+C_{2}\right) / 2\right)\right] \times 100\right],
$$

where

$C_{1}$ is the greater of the two concentrations, and

$C_{2}$ is the smaller of the two concentrations.

The RPD cannot be calculated if the concentration is censored or estimated in either or both samples. Large RPD values can result from low concentrations reported with few significant figures. For this study, RPD values greater than 20 percent were considered indicative of analytical results that might be affected by high variability. Twenty-two analytes (dissolved calcium, dissolved magnesium, dissolved chloride, dissolved sulfate, dissolved fluoride, total silica, total aluminum, total chromium, total copper, dissolved iron, total iron, dissolved molybdenum, total molybdenum, total thallium, dissolved vanadium, total vanadium, total boron, dissolved selenium, dissolved ammonia, dissolved nitrate, dissolved orthophosphate, and total nitrogen,) were qualified because of high variability. The RPDs greater than 20 percent are identified with a footnote on the primary environmental sample in tables 1-1, 1-3, 1-4, and 1-5.

\section{Water-Quality Data}

Summary statistics for groundwater samples collected from 146 wells for the WGQMN are presented for selected physical characteristics, major ions and DS, trace elements, nutrients and DOC, radionuclides, environmental isotopes, organic compounds (including VOCs, DRO, GRO, dissolved hydrocarbon gases, and wastewater compounds), and coliform bacteria (table 5). Water-quality measurements and concentrations for groundwater samples are compared to national and State drinking water standards (table 5). Results for individual samples are presented in the appendix (tables 1-1 through 1-9). Results also are displayed graphically by hydrogeologic unit in figures 3-35 for constituents with values exceeding water-quality standards or that are of interest to WDEQ. Data are electronically stored in the USGS's National Water Information System and are available to the public using the Web interface (NWISWeb) and the site identification numbers in table 3 (U.S. Geological Survey, 2014). 


\section{Physical Characteristics}

Onsite measurements of physical characteristics of groundwater are presented and summarized for all samples (table 5, table 1-2). Values for $\mathrm{pH}$ and turbidity are compared to applicable EPA and WDEQ standards (table 5). Water temperatures for 146 samples ranged from 5.5 to 18.4 degrees Celsius $\left({ }^{\circ} \mathrm{C}\right)$, with a median of $12.2^{\circ} \mathrm{C}$. Values for $\mathrm{pH}$ for 146 samples ranged from 6.2 to 9.6 , with a median of 7.4. Values for $\mathrm{pH}$ for 18 samples were outside of the acceptable range of 6.5-8.5 determined for the EPA SMCL, WDEQ Class I domestic groundwater-quality standard, and WDEQ Class III livestock groundwater-quality standard (fig. 3). Values for $\mathrm{pH}$ for four samples were outside of the acceptable range of 4.59.0 for the WDEQ Class II agriculture groundwater-quality standard. Values for $\mathrm{pH}$ for 10 samples were outside of the acceptable range of 6.5-9.0 for the WDEQ Class Special (A) fish and aquatic life groundwater-quality standard. Specific conductance, which is a measure of the capacity of water to conduct an electric current (Hem, 1989), in 146 samples ranged from 53.7 to 17,300 microsiemens per centimeter ( $\mu \mathrm{S} / \mathrm{cm}$ ), with a median of $497 \mu \mathrm{S} / \mathrm{cm}$.

Dissolved oxygen (DO) concentrations in 146 samples ranged from 0.05 to 10.3 milligrams per liter (mg/L), with a median of $3.41 \mathrm{mg} / \mathrm{L}$. The $\mathrm{DO}$ concentrations can be used to determine the reduction/oxidation (redox) state of groundwater. The redox state of groundwater affects the concentration, transport, and fate of many human and natural contaminants (Jurgens and others, 2009). Air that becomes entrained in the water column as a result of pumping, particularly in wells with short water columns or with pumps in poor condition, can cause an increase in measured DO concentrations compared to actual groundwater conditions. The oxidation reduction potential in 146 samples ranged from -269 to 374 millivolts (mV), with a median of $104 \mathrm{mV}$.

Alkalinity field values in 146 samples ranged from 14.3 to $1,090 \mathrm{mg} / \mathrm{L}$ as calcium carbonate $\left(\mathrm{mg} / \mathrm{L}\right.$ as $\left.\mathrm{CaCO}_{3}\right)$, with a median of $180 \mathrm{mg} / \mathrm{L}$ as $\mathrm{CaCO}_{3}$. Carbonate ranged from less than $(<) 0.1$ to $34.8 \mathrm{mg} / \mathrm{L}$ as carbonate $\left(\mathrm{CO}_{3}\right)$, with a median of $0.40 \mathrm{mg} / \mathrm{L}$ as $\mathrm{CO}_{3}$. Bicarbonate ranged from 17.3 to $1,310 \mathrm{mg} / \mathrm{L}$ as bicarbonate $\left(\mathrm{HCO}_{3}\right)$, with a median of $214 \mathrm{mg} / \mathrm{L}$ as $\mathrm{HCO}_{3}$.

Turbidity in 146 samples ranged from 0.11 to 346 nephelometric turbidity ratio units (NTRU), with a median of 0.60 NTRU. Values of turbidity in 12 samples exceeded the EPA SMCL of 5.0 NTRU (fig. 4). 


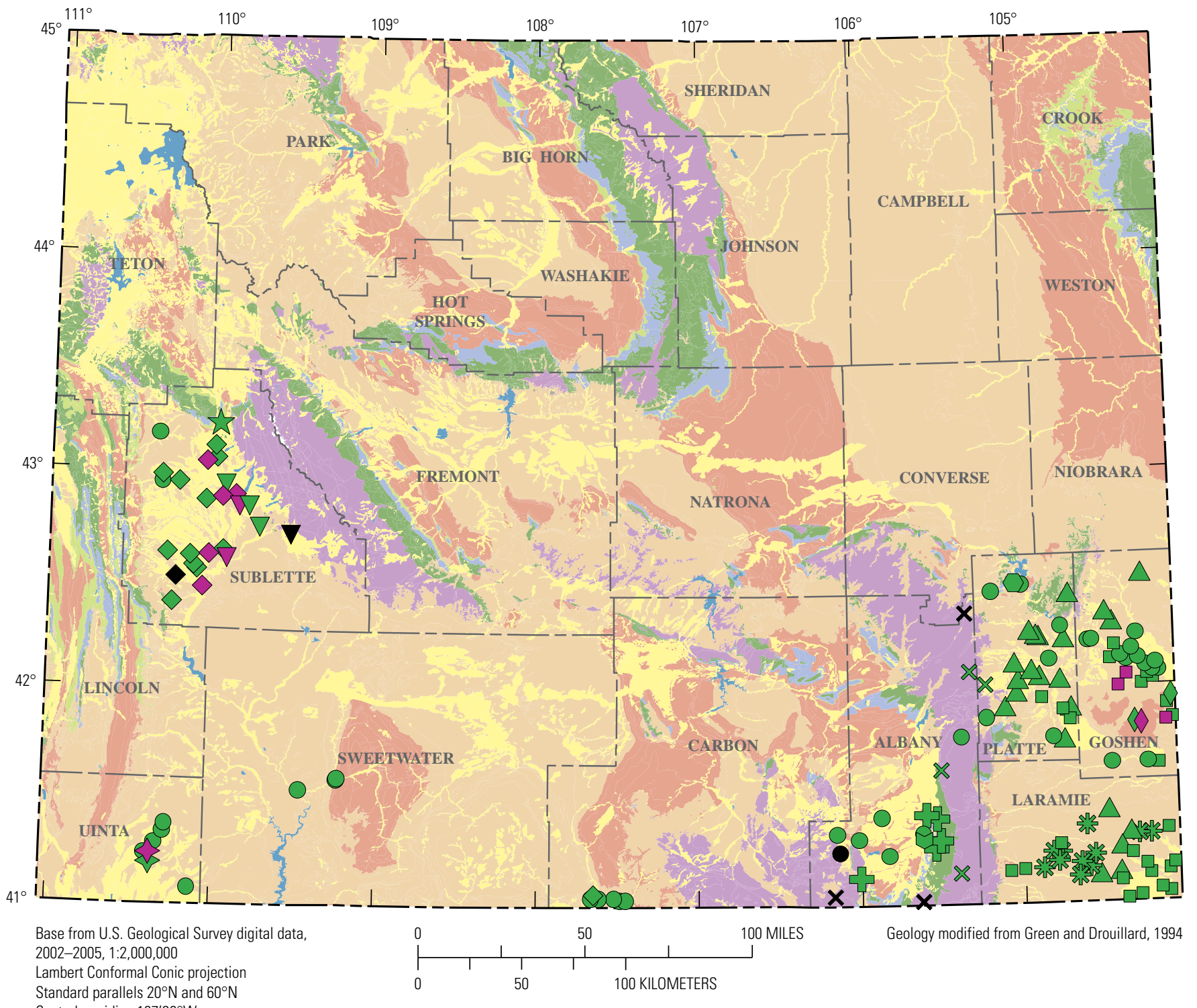

Central meridian $107^{\prime} 30^{\circ} \mathrm{W}$

North American Datum of 1983

\section{EXPLANATION}

Lithostratigraphic unit

Quaternary

Tertiary

Cretaceous

Jurassic

Triassic

Paleozoic

Precambrian

Open water
Hydrogeologic unit in which well was completed-Symbol shape represents unit or aquifer

Quaternary unconsolidateddeposit aquifers

\section{Bedrock aquifers}

Ogallala aquifer

$\triangle$ Arikaree aquifer

$\square \quad$ White River aquifer

$\diamond$ Bridger aquifer

$\diamond$ Wasatch aquifer

$\nabla$ Farson Sandstone-Alkali Creek aquifer

$$
\begin{aligned}
& \triangle \text { Lance aquifer } \\
& \checkmark \text { Sundance aquifer } \\
& \checkmark \text { Nugget aquifer } \\
& \square \text { Casper aquifer } \\
& \bigotimes \text { Hartville aquifer } \\
& \begin{array}{c}
\text { Precambrian } \\
\text { aquifer }
\end{array}
\end{aligned}
$$

pH, in standard units - Symbol color represents concentration. Symbols are arranged by geologic age from youngest to oldest (left to right)

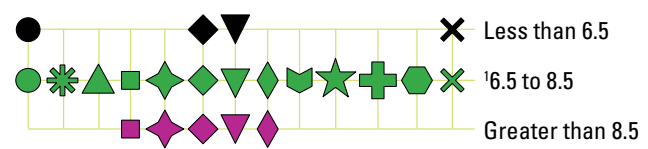

'U.S. Environmental Protection Agency Secondary Maximum Contaminant Level (U.S. Environmental Protection Agency, 2012c) and Wyoming Department of Environmental Quality Class I domestic and Class III livestock groundwater standards (Wyoming Department of Environmental Quality, 2005).

Figure 3. Values of $\mathrm{pH}$ in groundwater from wells sampled for the Wyoming Groundwater-Quality Monitoring Network, November 2009 through September 2012. 


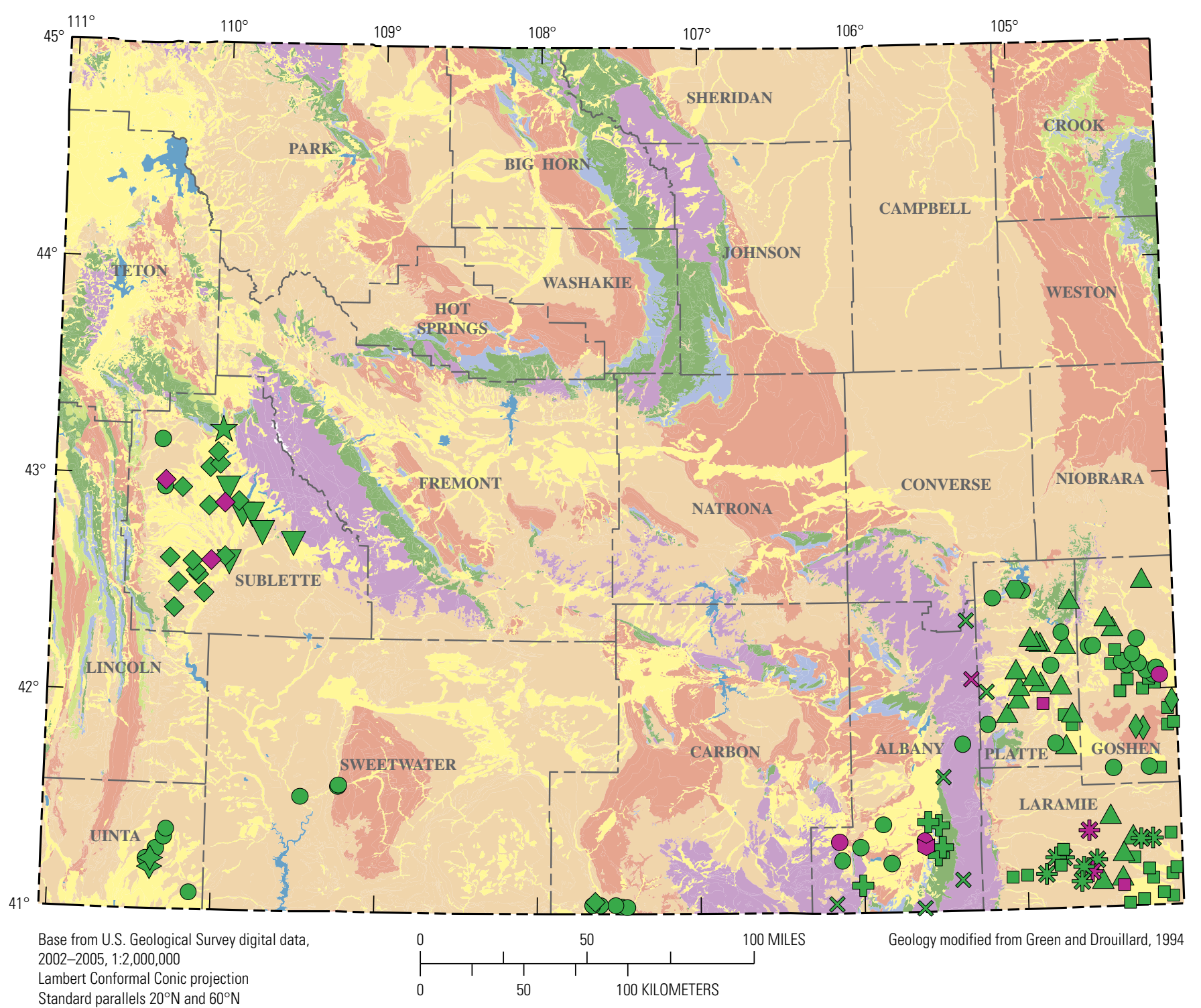

Central meridian $107^{\prime} 30^{\circ} \mathrm{W}$

North American Datum of 1983

\section{EXPLANATION}

Lithostratigraphic unit

\begin{tabular}{|l|}
\hline Quaternary \\
\hline Tertiary \\
\hline Cretaceous \\
\hline Jurassic \\
\hline Triassic \\
\hline Paleozoic \\
\hline Precambrian \\
\hline Open water \\
\hline
\end{tabular}

Hydrogeologic unit in which well was completed-Symbol shape represents unit or aquifer

Quaternary unconsolidateddeposit aquifers

\section{Bedrock aquifers}

致 Ogallala aquifer

$\triangle$ Arikaree aquifer

$\square \quad$ White River aquifer

$\diamond$ Bridger aquifer

$\diamond$ Wasatch aquifer

$\nabla$ Farson Sandstone-Alkali Creek aquifer

$\checkmark$ Sundance aquife

ك Casper aquifer

$\triangle$ Hartville aquifer

\& Precambrian aquifer
Turbidity, in nephelometric turbidity ratio units-Symbol color represents concentration. Symbols are arranged by geologic age from youngest to oldest (left to right)

$\bigcirc \Delta \square \Delta \nabla \begin{array}{r}\text { Greater than or equal } \\ \text { to detection limit }\end{array}$ and less than 5

$\aleph$ Nugget aquifer

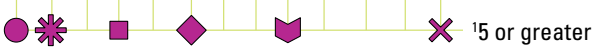

'U.S. Environmental Protection Agency Secondary Maximum Contaminant Level (U.S. Environmental Protection Agency, 2012c).

Figure 4. Values of turbidity in groundwater from wells sampled for the Wyoming Groundwater-Quality Monitoring Network, November 2009 through September 2012. 


\section{Major Ions and Dissolved Solids}

Major ions, which include major cations and anions, comprise most of the dissolved constituents in groundwater and generally occur as a result of recharge and interactions between water and soil or rock (Bartos and others, 2004). Silica also is reported with major ions, although it is an uncharged species for most $\mathrm{pH}$ conditions. Major ions waterquality data collected for the WGQMN are reported in table 5. Results from individual analyses are presented in table 1-3.

Major cations analyzed in samples for the WGQMN included dissolved calcium, dissolved magnesium, dissolved sodium, and dissolved potassium. Dissolved calcium concentrations for 146 samples ranged from 0.86 to $533 \mathrm{mg} / \mathrm{L}$, with a median of $48.6 \mathrm{mg} / \mathrm{L}$. Dissolved magnesium concentrations for 146 samples ranged from $<0.10$ to $1,200 \mathrm{mg} / \mathrm{L}$, with a median (calculated using the log-probability regression procedure) of $11.2 \mathrm{mg} / \mathrm{L}$. Dissolved sodium concentrations for 146 samples ranged from 1.66 to $3,270 \mathrm{mg} / \mathrm{L}$, with a median of $39.3 \mathrm{mg} / \mathrm{L}$. Dissolved potassium concentrations for 146 samples ranged from $<1.00$ to

$53.5 \mathrm{mg} / \mathrm{L}$, with a median (calculated using the log-probability regression procedure) of $4.49 \mathrm{mg} / \mathrm{L}$.

Major anions analyzed in samples for the WGQMN included dissolved chloride, dissolved sulfate, and dissolved fluoride. Dissolved chloride concentrations for 140 samples ranged from $<0.50$ to $1,960 \mathrm{mg} / \mathrm{L}$, with a median (calculated using the log-probability regression procedure) of $8.60 \mathrm{mg} / \mathrm{L}$. The WDEQ Class II agriculture groundwater-quality standard for chloride $(100 \mathrm{mg} / \mathrm{L})$ was exceeded in five samples. The EPA SMCL and WDEQ Class I domestic groundwater-quality standard for chloride $(250 \mathrm{mg} / \mathrm{L})$ were exceeded in three samples (fig. 5).

Dissolved sulfate concentrations for 140 samples ranged from 2.30 to $8,790 \mathrm{mg} / \mathrm{L}$, with a median of $37.3 \mathrm{mg} / \mathrm{L}$. The WDEQ Class II agriculture groundwater-quality standard for sulfate (200 mg/L) was exceeded in 23 samples. The EPA SMCL and WDEQ Class I domestic groundwater-quality standard for sulfate $(250 \mathrm{mg} / \mathrm{L}$ ) were exceeded in 16 samples. The WDEQ Class III livestock groundwater-quality standard for sulfate $(3,000 \mathrm{mg} / \mathrm{L})$ was exceeded in 3 samples (fig. 6).

Dissolved fluoride concentrations for 140 samples ranged from 0.13 to $3.87 \mathrm{mg} / \mathrm{L}$, with a median (calculated using the log-probability regression procedure) of $0.50 \mathrm{mg} / \mathrm{L}$. The EPA SMCL for fluoride $(2.0 \mu \mathrm{g} / \mathrm{L})$ was exceeded in five samples (fig. 7). Dissolved silica concentrations in 146 samples ranged from 4.63 to $69.8 \mathrm{mg} / \mathrm{L}$, with a median of $20.9 \mathrm{mg} / \mathrm{L}$.

Dissolved solids concentrations in 146 samples ranged from 40.8 to $17,600 \mathrm{mg} / \mathrm{L}$, with a median of $340 \mathrm{mg} / \mathrm{L}$. Compared to the USGS salinity classification (Heath, 1983, p. 65, table 2), 136 samples were classified as fresh (DS concentrations less than 1,000 mg/L), 6 samples were classified as slightly saline (DS concentrations ranging from $1,000$ to less than $3,000 \mathrm{mg} / \mathrm{L}), 2$ samples were classified as moderately saline (DS concentrations ranging from 3,000 to less than $10,000 \mathrm{mg} / \mathrm{L}$ ), and 2 samples were classified as very saline (DS concentrations ranging from 10,000 to less than $35,000 \mathrm{mg} / \mathrm{L}$ ) (table 6 at end of report). The EPA SMCL and WDEQ Class I domestic groundwater-quality standard for DS (500 mg/L) was equaled or exceeded in 49 samples. The WDEQ Class II agriculture groundwater-quality standard for DS $(2,000 \mathrm{mg} / \mathrm{L})$ was equaled or exceeded in six samples. The WDEQ Class III livestock groundwater-quality standard for DS $(5,000 \mathrm{mg} / \mathrm{L})$ was exceeded in four samples. The WDEQ Class IV industry groundwater standard for DS $(10,000 \mathrm{mg} / \mathrm{L})$ was exceeded in two samples. The WDEQ Class Special (A) fish and aquatic life groundwater-quality standard ranges from 500 to $2,000 \mathrm{mg} / \mathrm{L}$, depending on the specific use of the water. The WDEQ standard for DS that applies to groundwater used for fish egg hatching $(500 \mathrm{mg} / \mathrm{L})$ was equaled or exceeded in 49 samples (fig. 8). 


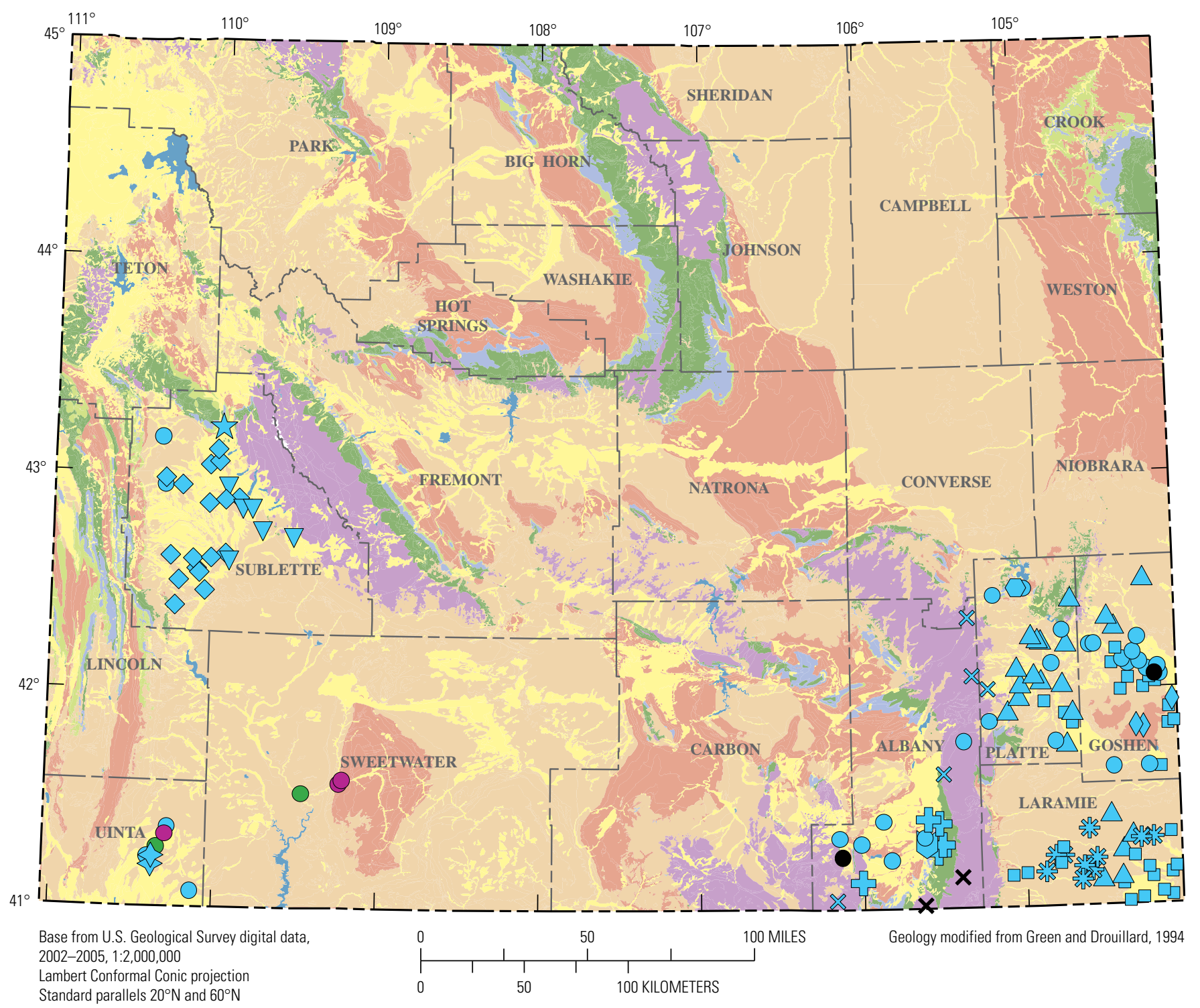

Standard parallels $20^{\circ} \mathrm{N}$ and $60^{\circ} \mathrm{N}$

Central meridian $107^{\prime} 30^{\circ} \mathrm{W}$

North American Datum of 1983

\section{EXPLANATION}

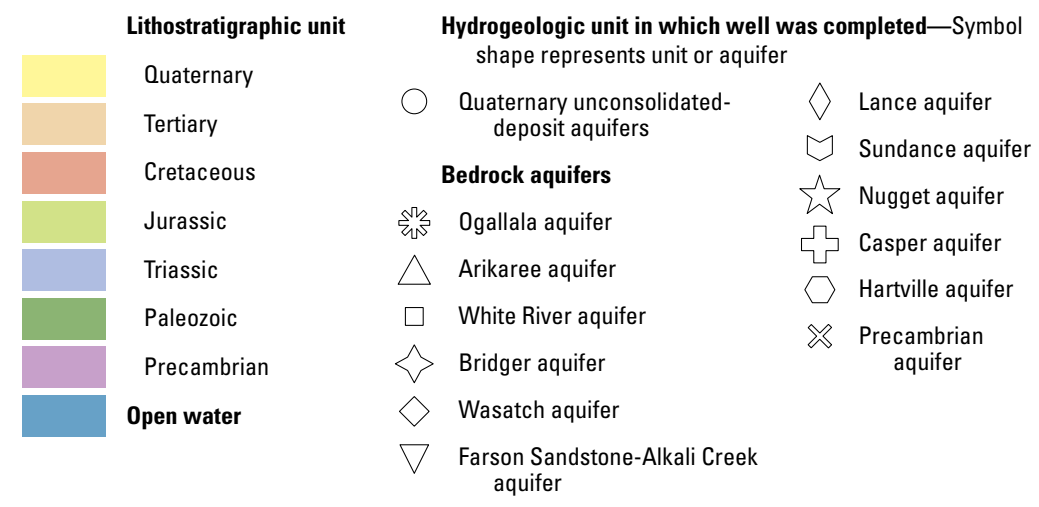

Dissolved chloride, in milligrams per liter-Symbol color represents concentration. Symbols are arranged by geologic age from youngest to oldest (left to right)

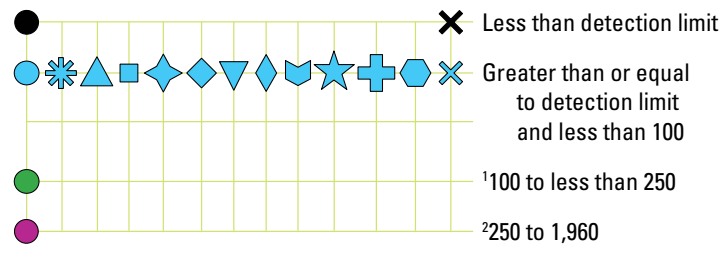

'Wyoming Department of Environmental Quality Class II agriculture groundwater standard (Wyoming Department of Environmental Quality, 2005).

${ }^{2}$ U.S. Environmental Protection Agency Secondary Maximum Contaminant Level (U.S. Environmental Protection Agency, 2012c) and Wyoming Department @f Environmental Quality Class I domestic groundwater standard (Wyoming Department of Environmental Quality, 2005).

Figure 5. Concentrations of dissolved chloride in groundwater from wells sampled for the Wyoming groundwater-quality monitoring network, November 2009 through September 2012. 


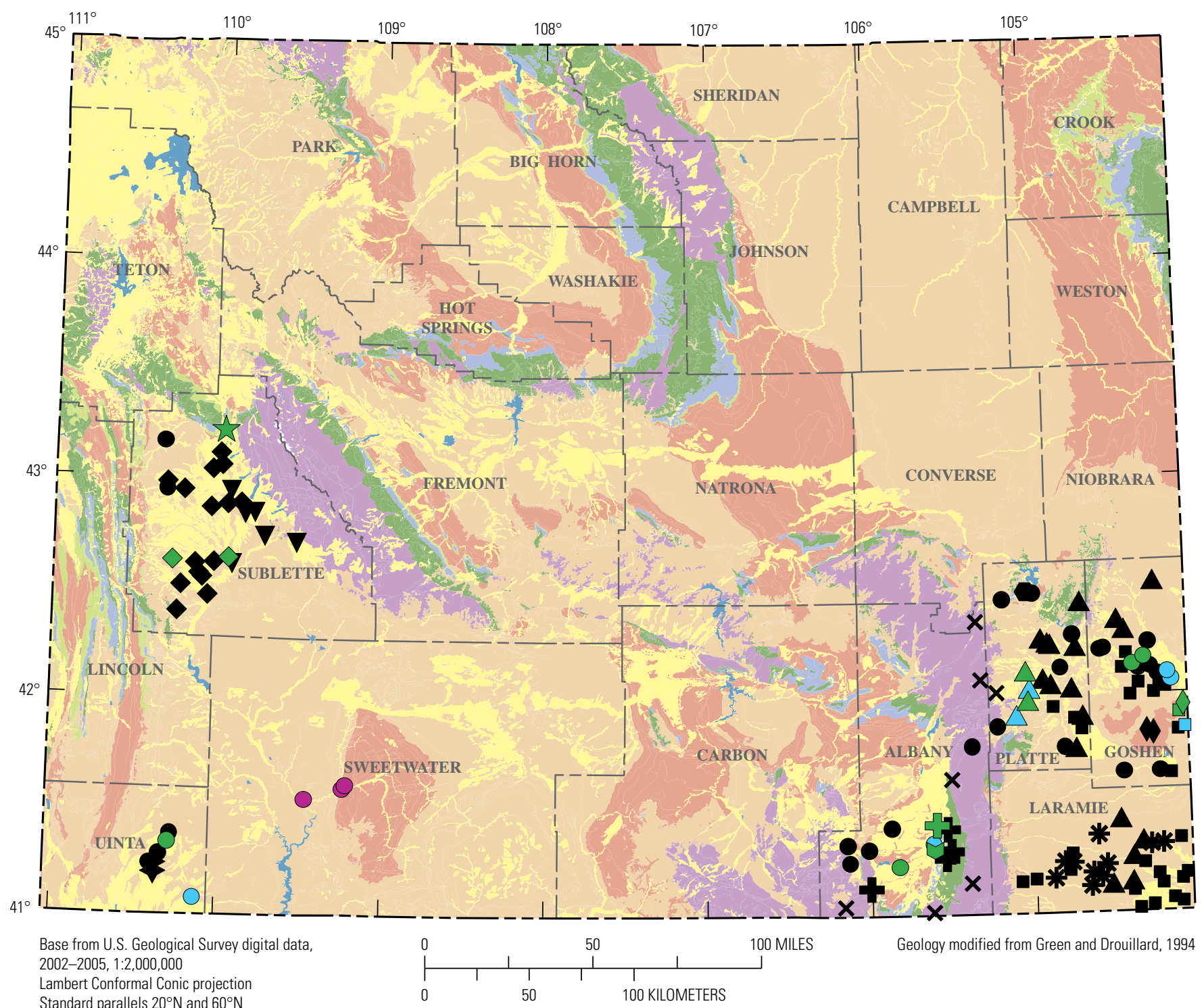

Standard parallels $20^{\circ} \mathrm{N}$ and $60^{\circ} \mathrm{N}$

Central meridian $107^{\prime} 30^{\circ} \mathrm{W}$

North American Datum of 1983

\section{EXPLANATION}

Lithostratigraphic unit

Quaternary

Tertiary

Cretaceous

Jurassic

Triassic

Paleozoic

Precambrian

Open water
Hydrogeologic unit in which well was completed-Symbol shape represents unit or aquifer

Quaternary unconsolidateddeposit aquifers

\section{Bedrock aquifers}

Ogallala aquifer

$\triangle$ Arikaree aquifer

$\square \quad$ White River aquifer

$\Leftrightarrow$ Bridger aquifer

$\diamond$ Wasatch aquifer

$\nabla$ Farson Sandstone-Alkali Creek aquifer $\diamond$ Lance aquifer

$\checkmark$ Sundance aquifer

证 Nugget aquifer

ऽ Casper aquifer

$\bigcirc$ Hartville aquifer

¿ Precambrian aquifer

Dissolved sulfate, in milligrams per liter-Symbol color represents concentration. Symbols are arranged by geologic age from youngest to oldest (left to right)

$\bullet * \Delta \square \triangleleft \diamond \nabla \bullet$

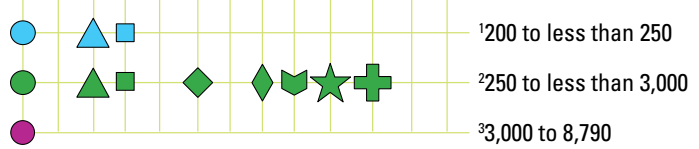

'Wyoming Department of Environmental Quality (WDEO) Class II agriculture groundwater standard (Wyoming Department of Environmental Quality, 2005). ${ }^{2}$ U.S. Environmental Protection Agency Secondary Maximum Contaminant Level and WDEO Class I domestic groundwater standard (U.S. Environmental Protection Agency, 2012c).

${ }^{3}$ WDEO Class III livestock groundwater standard (Wyoming Department of Environmental Quality, 2005).

Figure 6. Concentrations of dissolved sulfate in groundwater from wells sampled for the Wyoming groundwater-quality monitoring network, November 2009 through September 2012. 


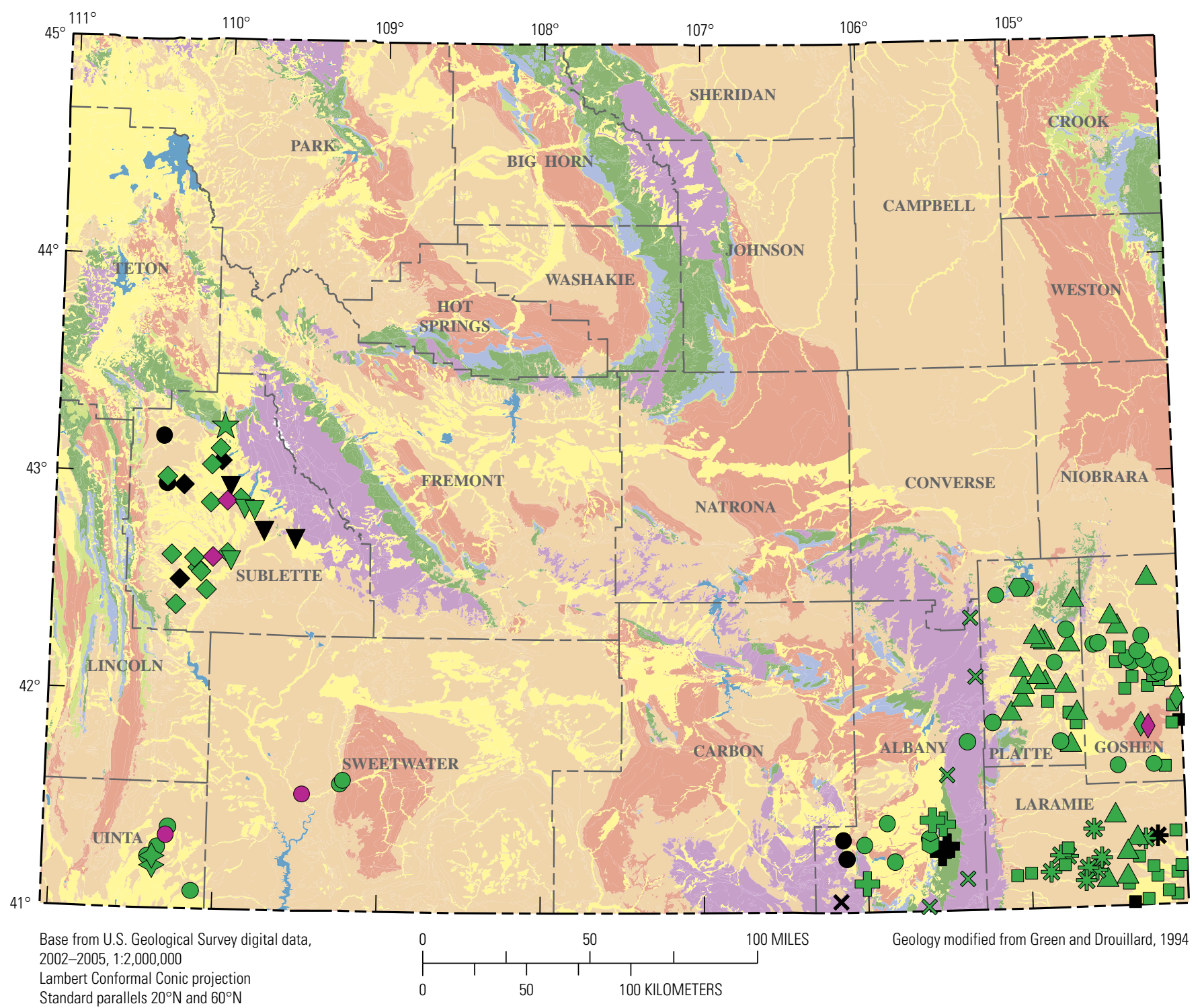

Standard parallels $20^{\circ} \mathrm{N}$ and $60^{\circ} \mathrm{N}$

Central meridian $107^{\prime} 30^{\circ} \mathrm{W}$

North American Datum of 1983

\section{EXPLANATION}

Lithostratigraphic unit

Quaternary

Tertiary

Cretaceous

Jurassic

Triassic

Paleozoic

Precambrian

Open water
Hydrogeologic unit in which well was completed-Symbol shape represents unit or aquifer

Quaternary unconsolidateddeposit aquifers

\section{Bedrock aquifers}

sh Ogallala aquifer

$\triangle$ Arikaree aquifer

$\square \quad$ White River aquifer

$\Leftrightarrow$ Bridger aquifer

$\diamond$ Wasatch aquifer

$\nabla$ Farson Sandstone-Alkali Creek aquifer
Dissolved fluoride, in milligrams per liter-Symbol color represents concentration. Symbols are arranged by geologic age from youngest to oldest (left to right)

$$
\begin{aligned}
& \triangle \text { Lance aquifer } \\
& \checkmark \text { Sundance aquifer } \\
& \checkmark \text { Nugget aquifer } \\
& \square \text { Casper aquifer } \\
& \text { Hartville aquifer } \\
& \begin{array}{c}
\text { Precambrian } \\
\text { aquifer }
\end{array}
\end{aligned}
$$

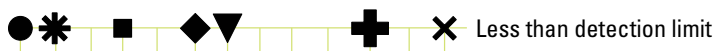
to detection limit
to and less than 2

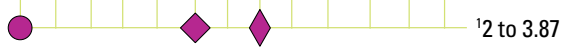

'U.S. Environmental Protection Agency Secondary Maximum Contaminant Level (U.S. Environmental Protection Agency, 2012c).

Figure 7. Concentrations of dissolved fluoride in groundwater from wells sampled for the Wyoming groundwater-quality monitoring network, November 2009 through September 2012. 


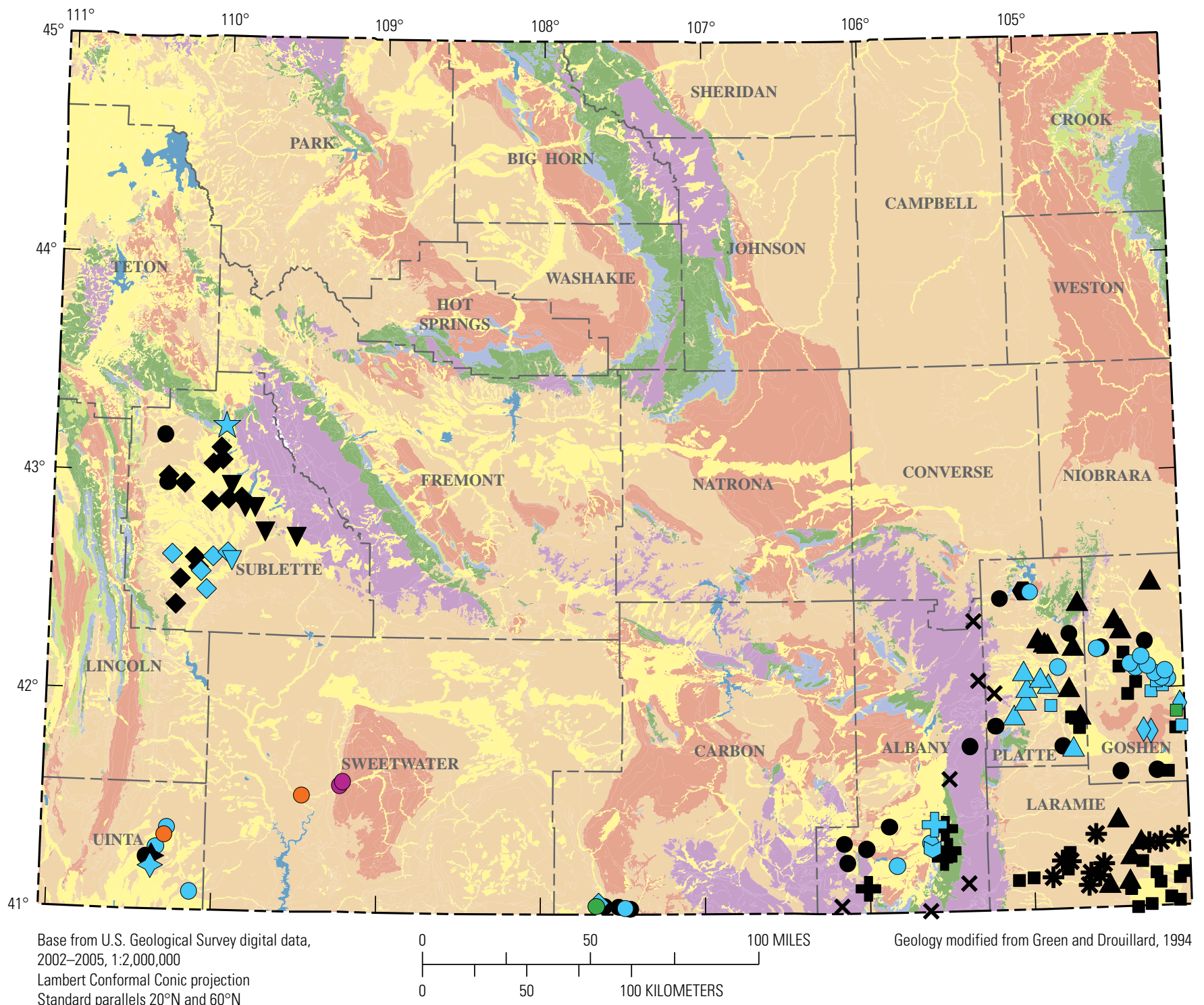

Standard parallels $20 \mathrm{~N}^{\circ}$ and $60 \mathrm{~N}$

Central meridian $107^{\prime} 30^{\circ} \mathrm{W}$

North American Datum of 1983

\section{EXPLANATION}

Lithostratigraphic unit

Hydrogeologic unit in which well was completed-Symbol shape represents unit or aquifer

Quaternary

Tertiary

Cretaceous

Quaternary unconsolidateddeposit aquifers

$\checkmark$ Lance aquifer

Bedrock aquifers

Jurassic Ogallala aquifer

Triassic $\triangle$ Arikaree aquifer

Paleozoic

Precambrian

Open water $\square \quad$ White River aquifer

$\vartheta$ Bridger aquifer

$\diamond$ Wasatch aquifer

$\nabla$ Farson Sandstone-Alkali Creek aquifer
Dissolved solids, in milligrams per liter-Symbol color represents concentration. Symbols are arranged by geologic age from youngest to oldest (left to right)

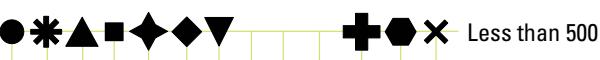

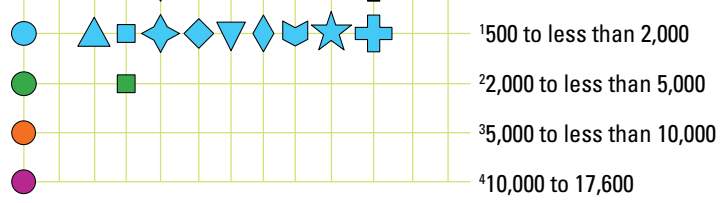

'U.S. Environmental Protection Agency Secondary Maximum Contaminant Level (U.S. Environmental Protection Agency, 2012c) and Wyoming Department of Environmental Quality (WDEO) Class I domestic and Class Special (A) fish and aquatic life groundwater standards (Wyoming Department of Environmental Quality, 2005).

${ }^{2}$ WDEO Class II agriculture groundwater standard (Wyoming Department of Environmental Quality, 2005).

${ }^{3}$ WDEO Class III livestock groundwater standard (Wyoming Department of Environmental Quality, 2005).

${ }^{4}$ WDEO Class IV industry groundwater standard (Wyoming Department of Environmental Quality, 2005).

Figure 8. Concentrations of dissolved solids in groundwater from wells sampled for the Wyoming groundwater-quality monitoring network, November 2009 through September 2012. 
Trilinear diagrams were constructed to characterize major-ion chemistry and DS concentration by hydrogeologic unit (figs. 9-17). Water type was determined using concentrations expressed as milliequivalents to calculate the percentage of total cations for each of the major cations (calcium, magnesium, sodium, and potassium) and the percentage of total anions for each of the major anions (carbonate, bicarbonate, chloride, sulfate, fluoride, and nitrate). The triangles on the bottom left and right show the relative percentages of cations and anions, whereas the quadrangle in the center is a combination of all the ion data (Piper, 1944). Samples from wells completed in Quaternary unconsolidated-deposit aquifers were of many different water types (fig. 9). Chloride, sulfate, fluoride, and nitrate values were not determined for samples from five wells completed in Quaternary unconsolidated-deposit aquifers so those samples are not included on figure 9 . The percentage of sulfate relative to bicarbonate increased with increasing DS concentrations.

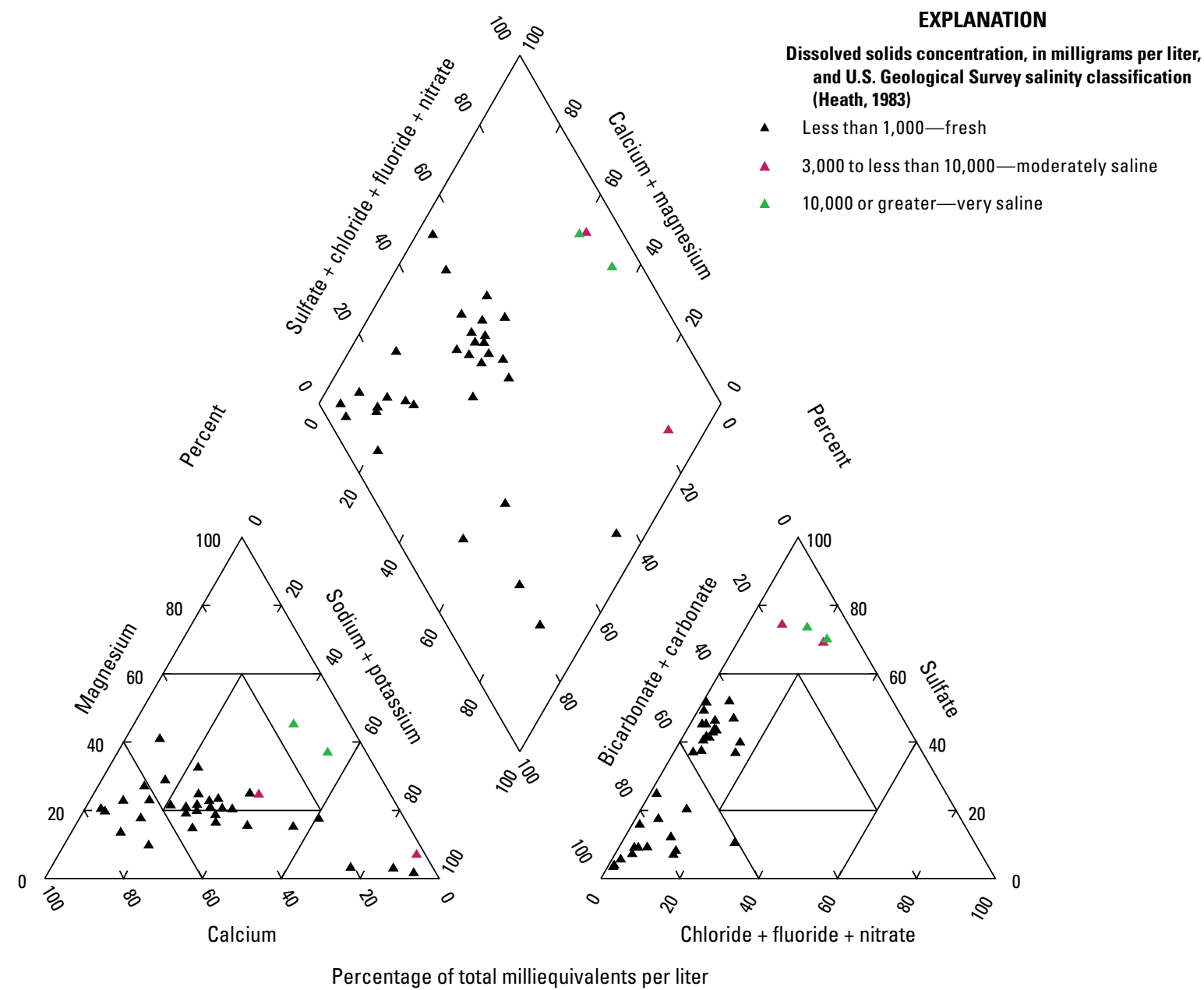

Figure 9. Trilinear diagram characterizing major-ion chemistry and dissolved solids concentrations for groundwater samples collected from Quaternary unconsolidated-deposit aquifers, Wyoming, November 2009 through September 2012. 
Samples from wells completed in the Ogallala aquifer were calcium bicarbonate waters (fig. 10).

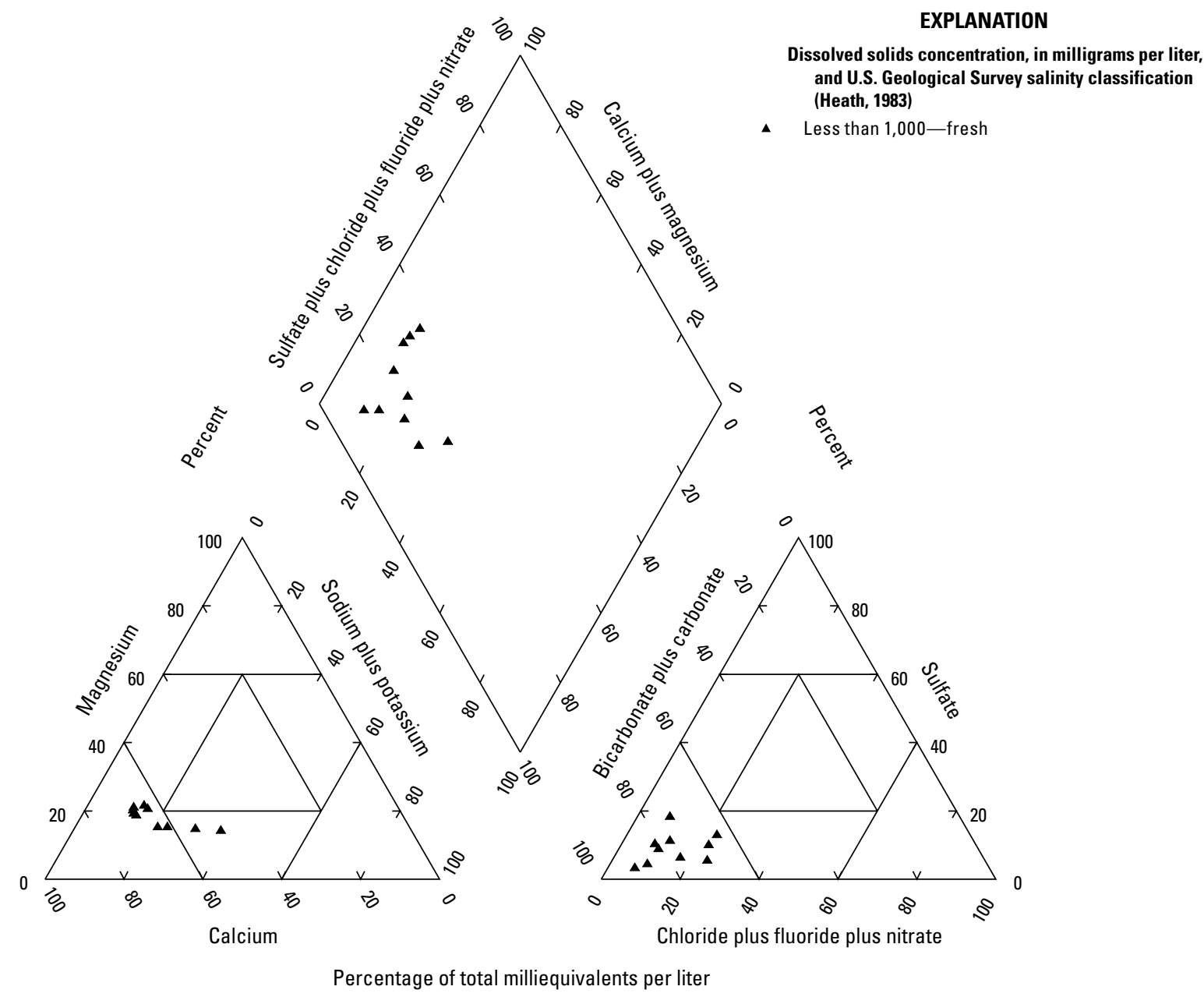

Figure 10. Trilinear diagram characterizing major-ion chemistry and dissolved solids concentrations for groundwater samples collected from wells completed in the Ogallala aquifer in Wyoming, November 2009 through September 2012. 
Samples from wells completed in the Arikaree aquifer were calcium bicarbonate and calcium-sodium bicarbonate waters (fig. 11).

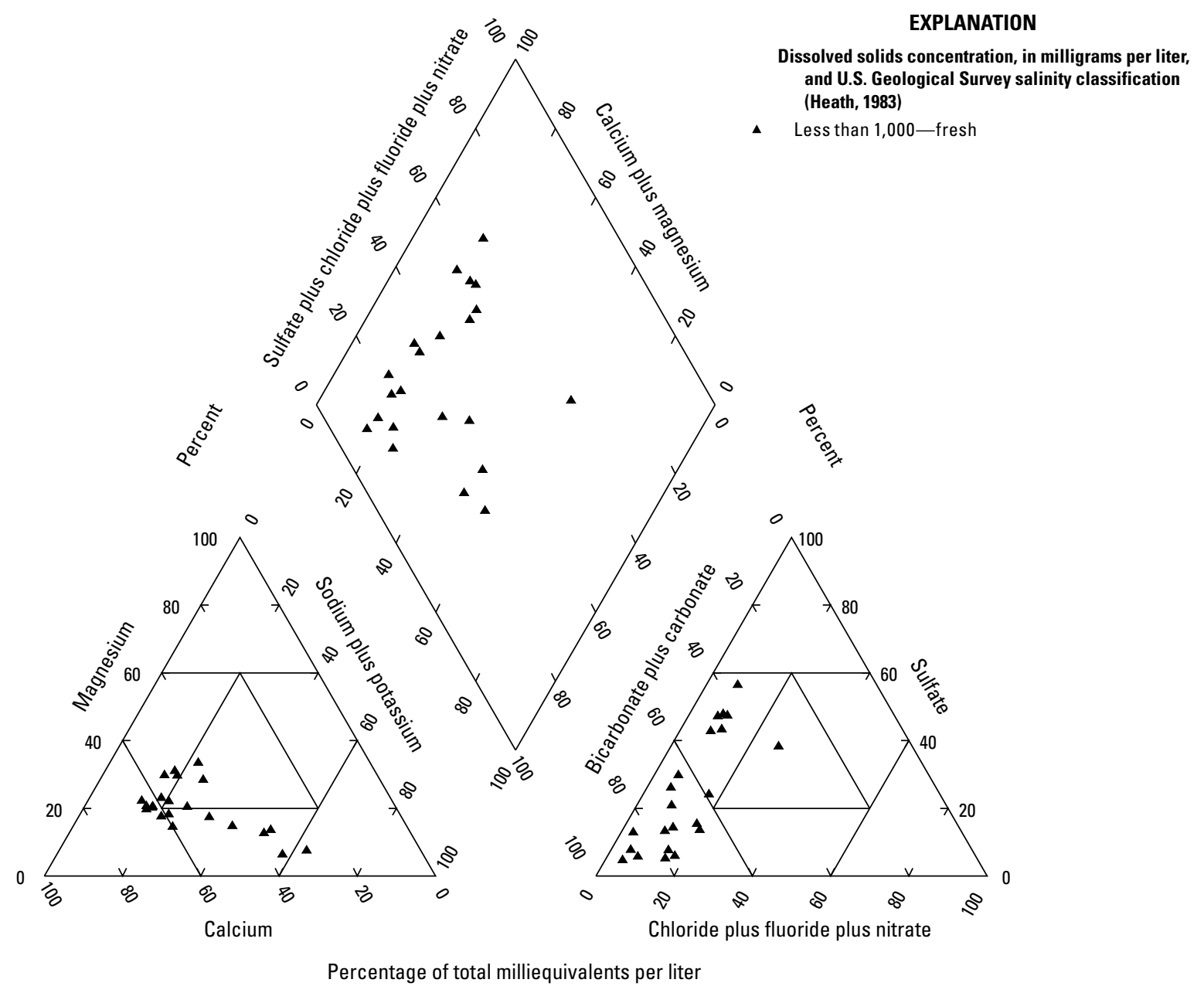

Figure 11. Trilinear diagram characterizing major-ion chemistry and dissolved solids concentrations for groundwater samples collected from wells completed in the Arikaree aquifer in Wyoming, November 2009 through September 2012. 
Samples from wells completed in the White River group (White River, Brule, and Chadron aquifers) were calcium bicarbonate, calcium-sodium bicarbonate, and sodium bicarbonate waters (fig. 12).

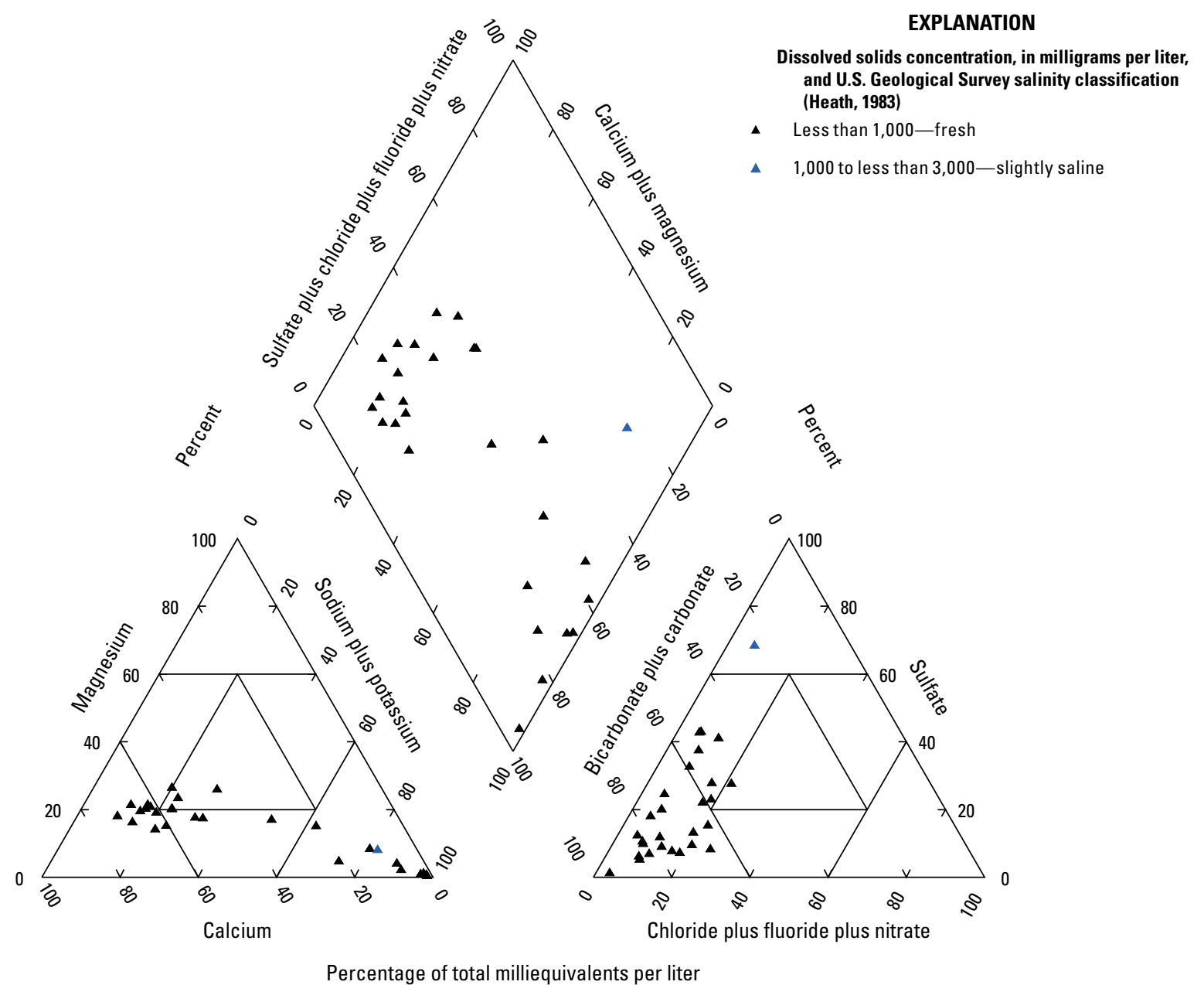

Figure 12. Trilinear diagram characterizing major-ion chemistry and dissolved solids concentrations for groundwater samples collected from wells completed in the White River Group (White River, Brule, and Chadron aquifers) in Wyoming, November 2009 through September 2012. 


\section{Groundwater-Quality Characteristics for the Wyoming Groundwater-Quality Monitoring Network}

Samples from wells completed in the Bridger and Farson Sandstone-Alkali Creek aquifers were calcium bicarbonate and sodium bicarbonate waters (fig. 13).

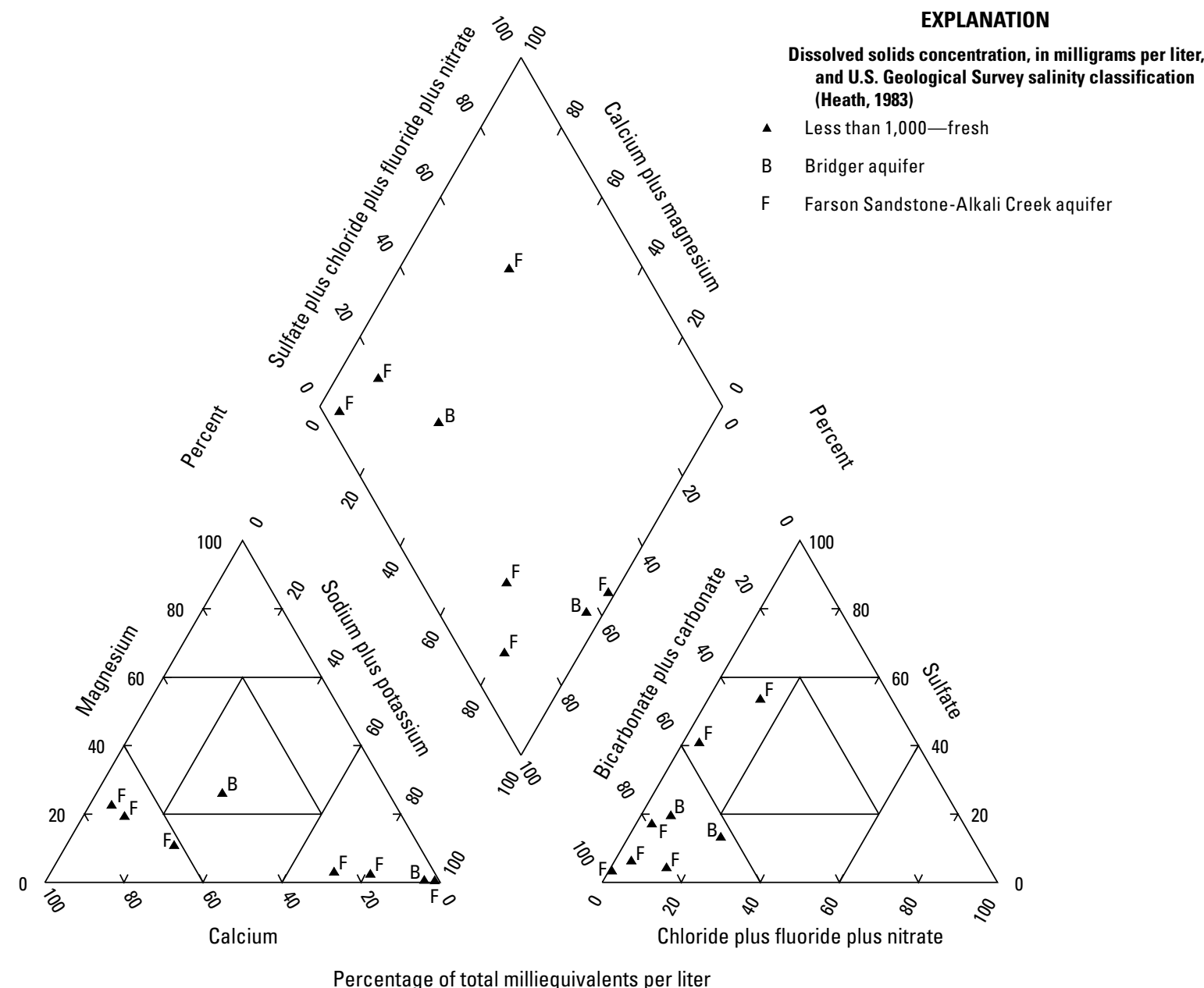

Figure 13. Trilinear diagram characterizing major-ion chemistry and dissolved solids concentrations for groundwater samples collected from wells completed in the Bridger and Farson Sandstone-Alkali Creek aquifers in Wyoming, November 2009 through September 2012. 
Samples from wells completed in the Wasatch aquifer were mixed cation bicarbonate waters (fig. 14). Chloride, sulfate, fluoride, and nitrate values were not determined for a sample from one well completed in the Wasatch aquifer so that sample is not included on figure 14 .

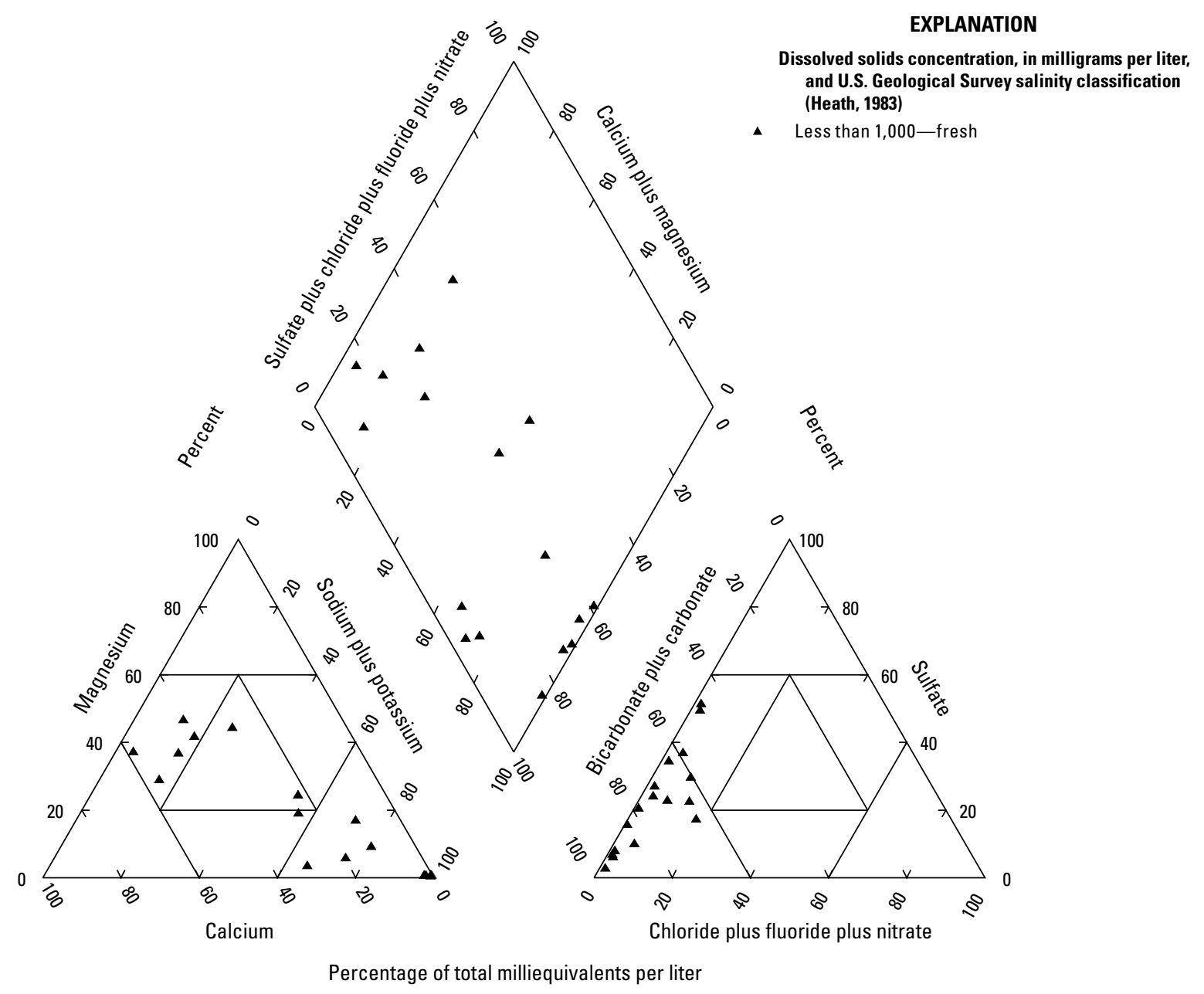

Figure 14. Trilinear diagram characterizing major-ion chemistry and dissolved solids concentrations for groundwater samples collected from wells completed in the Wasatch aquifer in Wyoming, November 2009 through September 2012. 
Samples from wells completed in Mesozoic hydrogeologic units (Lance, Sundance, and Nugget aquifers) were sodium waters (fig. 15). Samples from two wells completed in the Lance aquifer were sodium bicarbonate waters; samples from one well completed in the Lance aquifer and one well completed in the Nugget aquifer were sodium bicarbonate-sulfate waters; and a sample from one well completed in the Sundance aquifer was sodium sulfate water. The percentage of sulfate relative to bicarbonate increases with increasing DS concentrations for samples collected from these aquifers.

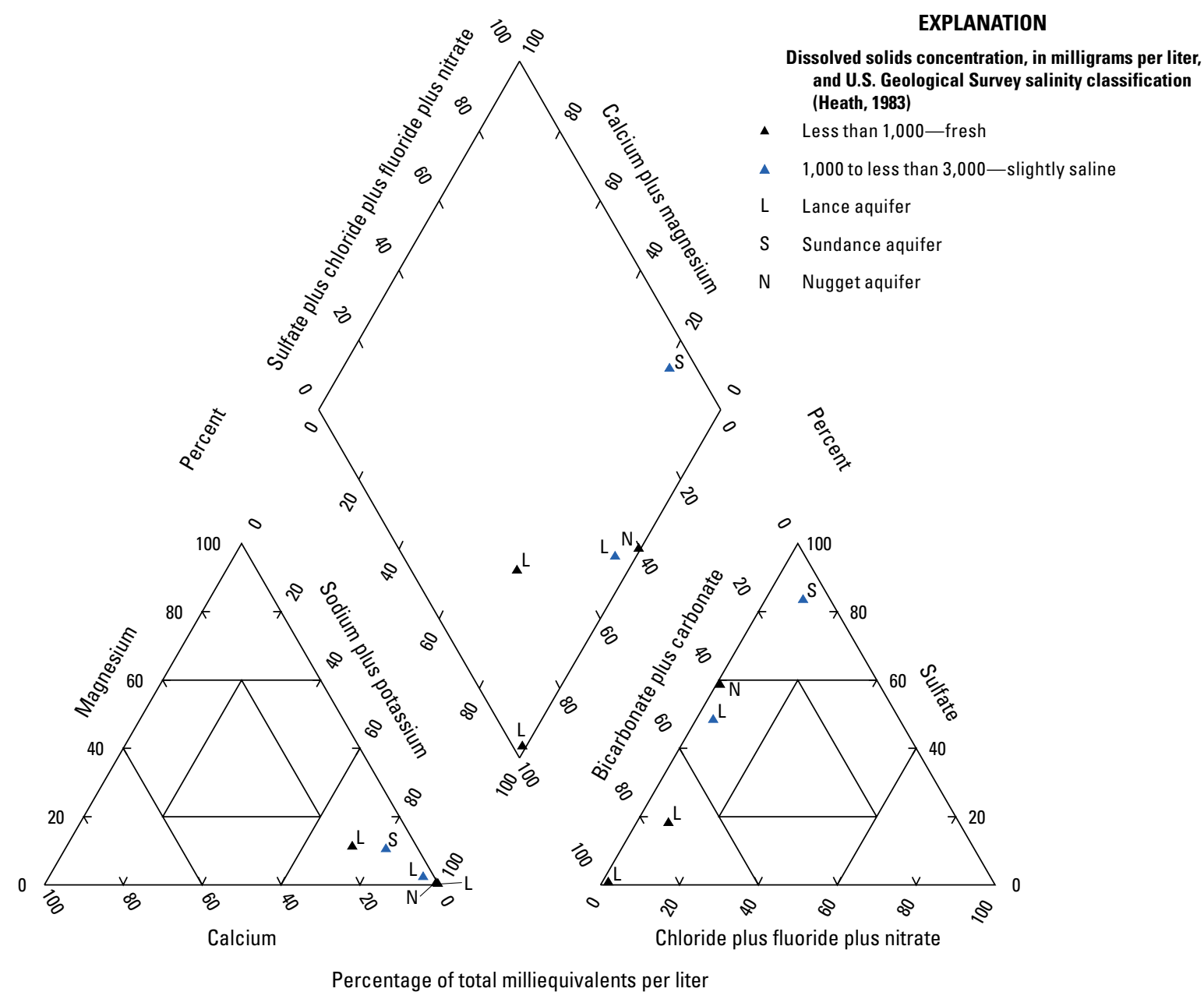

Figure 15. Trilinear diagram characterizing major-ion chemistry and dissolved solids concentrations for groundwater samples collected from wells completed in the Mesozoic hydrogeologic units (Lance, Sundance, and Nugget aquifers) in Wyoming, November 2009 through September 2012. 
Samples from wells completed in the Paleozoic hydrogeologic units (Casper and Hartville aquifers) were predominantly calcium bicarbonate waters but one sample from the Casper aquifer was mixed cation sulfate water (fig. 16).

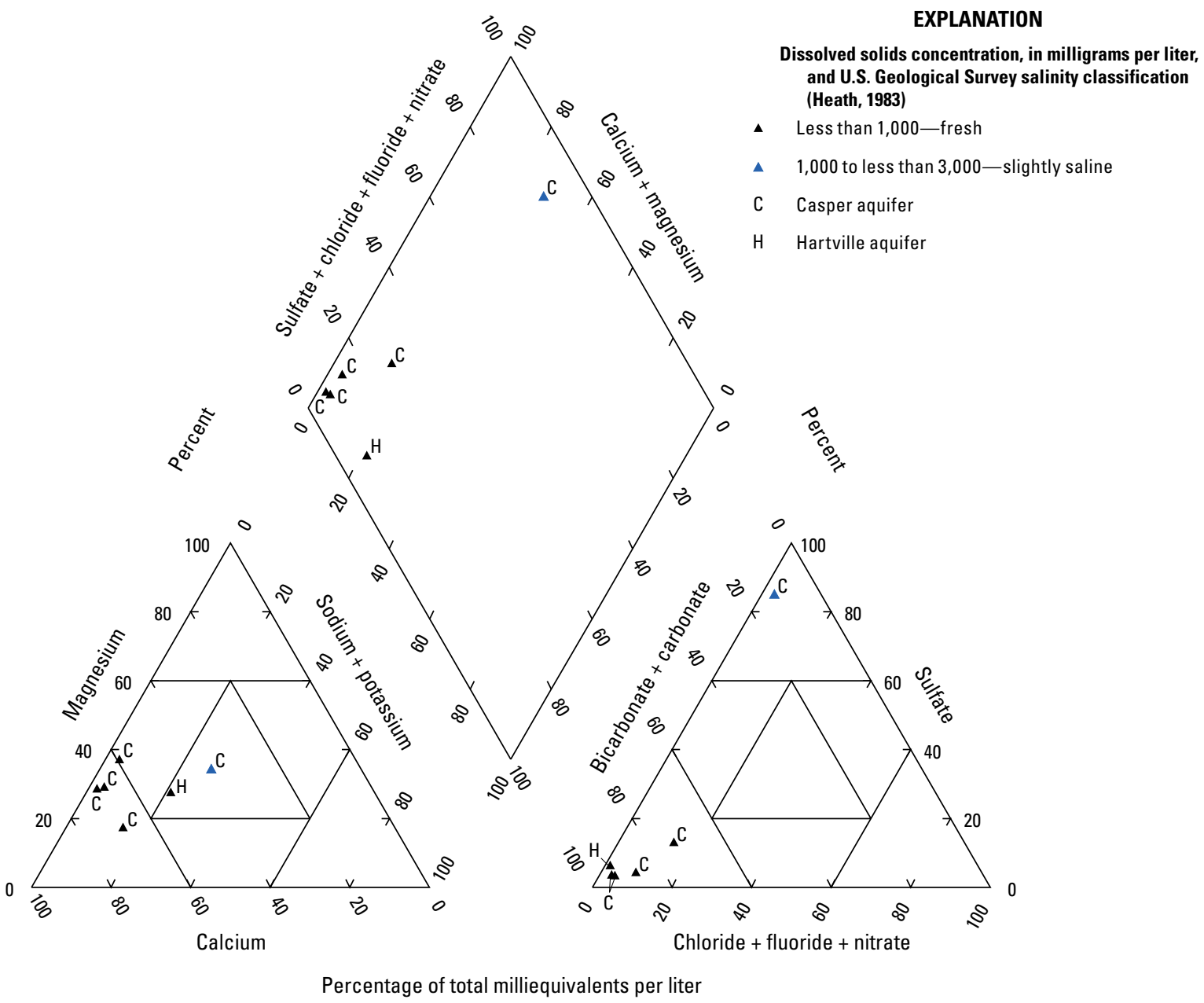

Figure 16. Trilinear diagram characterizing major-ion chemistry and dissolved solids concentrations for groundwater samples collected from wells completed in the Paleozoic hydrogeologic units (Casper and Hartville aquifers) in Wyoming, November 2009 through September 2012. 
Samples from wells completed in the Precambrian aquifer were calcium bicarbonate waters (fig. 17).

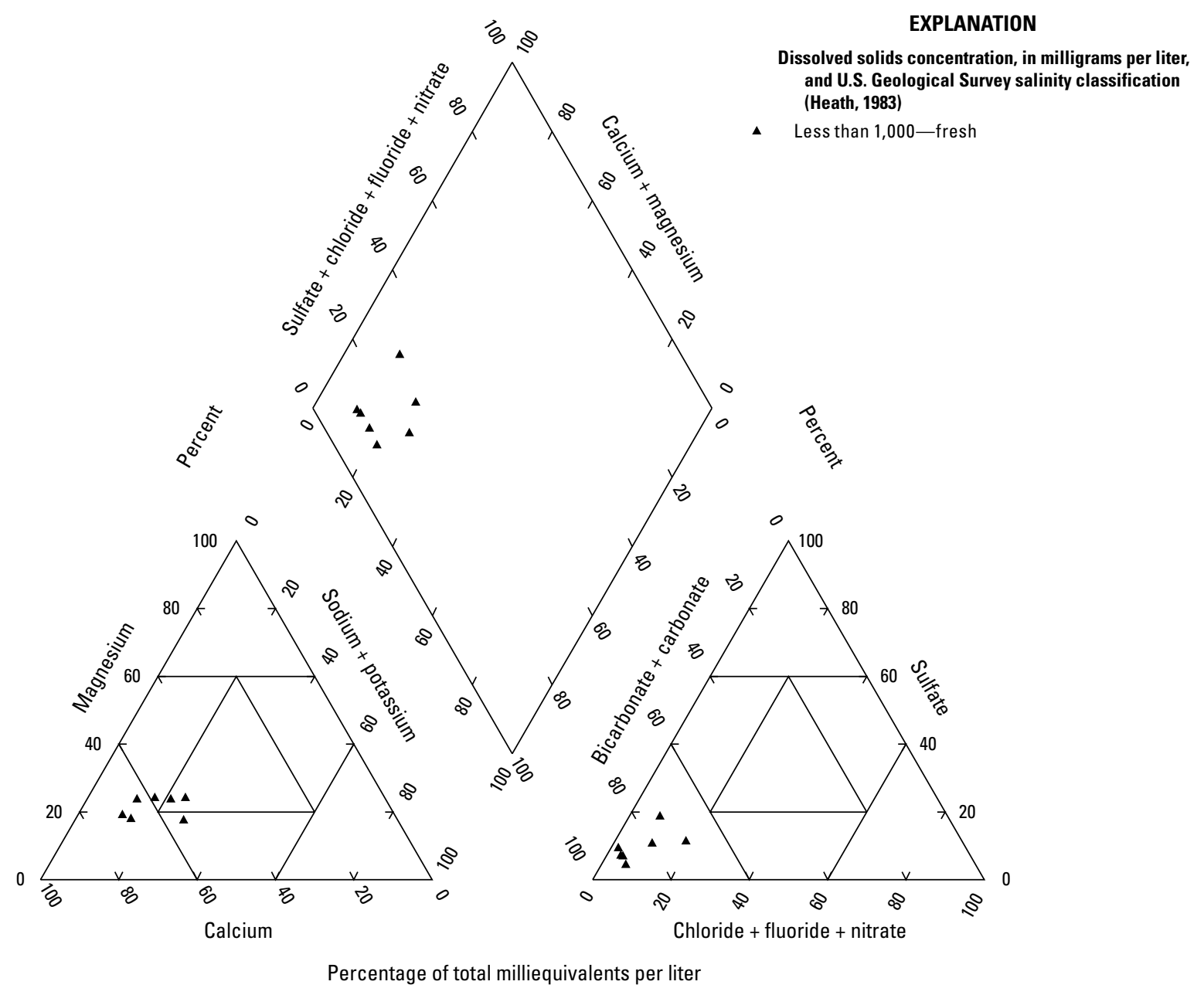

Figure 17. Trilinear diagram characterizing major-ion chemistry and dissolved solids concentrations for groundwater samples collected from wells completed in the Precambrian aquifer in Wyoming, November 2009 through September 2012. 


\section{Trace Elements}

Trace elements are a varied group of constituents, which includes metals and metalloids, that generally occur at small concentrations (less than $1 \mathrm{mg} / \mathrm{L}$ ) in natural groundwater (Hem, 1989). Total concentrations of trace elements in samples collected for the WGQMN were statistically summarized and compared to groundwater standards (table 5). Results from individual analyses, including results for dissolved trace elements, are presented for individual samples (table 1-4). It should be noted that some sampled wells were constructed of iron or steel, which can affect the concentrations of some trace elements (Lapham and others, 1995). Possible effects of well construction on trace element concentrations in groundwater samples were not assessed in this report.

Concentrations of total aluminum, total barium, total beryllium, and total cadmium were analyzed in 146 groundwater samples. Aluminum concentrations for 146 samples ranged from $<3.80$ to 7,330 micrograms per liter $(\mu \mathrm{g} / \mathrm{L})$. The median aluminum concentration (calculated using the log-probability regression procedure) for these samples was $0.504 \mu \mathrm{g} / \mathrm{L}$, which was less than the median aluminum concentration of $3.0 \mu \mathrm{g} / \mathrm{L}$ in groundwater samples collected across the United States during 1992-2003 for the USGS NAWQA Program (Ayotte and others, 2011). The EPA SMCL for aluminum (50-200 $\mu \mathrm{g} / \mathrm{L})$ was exceeded in 14 samples (fig. 18). The WDEQ Class Special (A) fish and aquatic life groundwater-quality standard for aluminum $(100 \mu \mathrm{g} / \mathrm{L})$ was exceeded in 14 samples. The WDEQ Class II agriculture groundwater-quality standard and WDEQ Class III livestock groundwater-quality standard for aluminum $(5,000 \mu \mathrm{g} / \mathrm{L})$ were exceeded in 1 sample. Barium concentrations for 146 samples ranged from $<4.00$ to $416 \mu \mathrm{g} / \mathrm{L}$. The median barium concentration (calculated using the log-probability regression procedure) was $63.0 \mu \mathrm{g} / \mathrm{L}$ for these samples, which was larger than the median barium concentration of $54 \mu \mathrm{g} / \mathrm{L}$ in groundwater samples collected across the United States during 1992-2003 for the USGS NAWQA Program (Ayotte and others, 2011). Beryllium was detected in 1 of 146 samples $(0.034 \mu \mathrm{g} / \mathrm{L})$ analyzed for the WGQMN. Beryllium concentrations generally are small in groundwater, as indicated by a median concentration of $<1.0 \mu \mathrm{g} / \mathrm{L}$ reported for groundwater samples collected across the United States during 1992-2003 for the USGS NAWQA Program (Ayotte and others, 2011). Cadmium concentrations for 146 samples ranged from $<0.016$ to $0.775 \mu \mathrm{g} / \mathrm{L}$. A median cadmium concentration could not be calculated for these samples using the log-probability regression procedure because too many values were censored. Cadmium concentrations generally are small in groundwater, as indicated by a median concentration of $<1.0 \mu \mathrm{g} / \mathrm{L}$ reported for groundwater samples collected across the United States during 1992-2003 for the USGS NAWQA Program (Ayotte and others, 2011).
Concentrations of total chromium, total cobalt, and total copper were analyzed in 146 groundwater samples. Chromium concentrations for 146 samples ranged from $<0.300$ to $16.5 \mu \mathrm{g} / \mathrm{L}$. The median chromium concentration for these samples (calculated using the log-probability regression procedure) was $0.162 \mu \mathrm{g} / \mathrm{L}$, which was less than the median chromium concentration of $1.2 \mu \mathrm{g} / \mathrm{L}$ in groundwater samples collected across the United States during 1992-2003 for the USGS NAWQA Program (Ayotte and others, 2011). Cobalt concentrations for 146 samples ranged from $<0.020$ to $2.64 \mu \mathrm{g} / \mathrm{L}$. The median cobalt concentration for these samples (calculated using log-probability regression procedure) was $0.018 \mu \mathrm{g} / \mathrm{L}$, which was less than median cobalt concentration of $0.17 \mu \mathrm{g} / \mathrm{L}$ in groundwater samples collected across the United States during 1992-2003 for the USGS NAWQA Program (Ayotte and others, 2011). Copper concentrations for 146 samples ranged from $<0.700$ to $535 \mu \mathrm{g} / \mathrm{L}$. The median copper concentration for these samples (calculated using the log-probability regression procedure) was $0.860 \mu \mathrm{g} / \mathrm{L}$, which was less than the median copper concentration of $1.0 \mu \mathrm{g} / \mathrm{L}$ in groundwater samples collected across the United States during 1992-2003 for the USGS NAWQA Program (Ayotte and others, 2011).

Total iron concentrations for 136 samples ranged from 33.3 to $11,200 \mu \mathrm{g} / \mathrm{L}$. The median iron concentration for these samples (calculated using the log-probability regression procedure) was $13.5 \mu \mathrm{g} / \mathrm{L}$, which was larger than the median iron concentration of $7.9 \mu \mathrm{g} / \mathrm{L}$ in groundwater samples collected across the United States during 1992-2003 for the USGS NAWQA Program (Ayotte and others, 2011). The EPA SMCL and WDEQ Class I domestic groundwater-quality standard for iron $(300 \mu \mathrm{g} / \mathrm{L})$ were exceeded in 13 samples. The WDEQ Class II agriculture groundwater-quality standard for iron $(5,000 \mu \mathrm{g} / \mathrm{L})$ was exceeded in 2 samples. The WDEQ Class Special (A) fish and aquatic life groundwater-quality standard for iron $(500 \mu \mathrm{g} / \mathrm{L})$ was exceeded in 10 samples (fig. 19).

Concentrations of total lead and total lithium were analyzed in groundwater samples. Lead concentrations for 146 samples ranged from E0.033 to $4.8 \mu \mathrm{g} / \mathrm{L}$. The median lead concentration for these samples (calculated using the log-probability regression procedure) was $0.042 \mu \mathrm{g} / \mathrm{L}$, which was less than the median lead concentration of $0.070 \mu \mathrm{g} / \mathrm{L}$ in groundwater samples collected across the United States during 1992-2003 for the USGS NAWQA Program (Ayotte and others, 2011). Lithium concentrations for 17 samples ranged from 4.29 to $602 \mu \mathrm{g} / \mathrm{L}$. The median lithium concentration for these samples was $30.1 \mu \mathrm{g} / \mathrm{L}$, which was larger than the median lithium concentration of $6.0 \mu \mathrm{g} / \mathrm{L}$ in groundwater samples collected across the United States during 1992-2003 for the USGS NAWQA Program (Ayotte and others, 2011). 


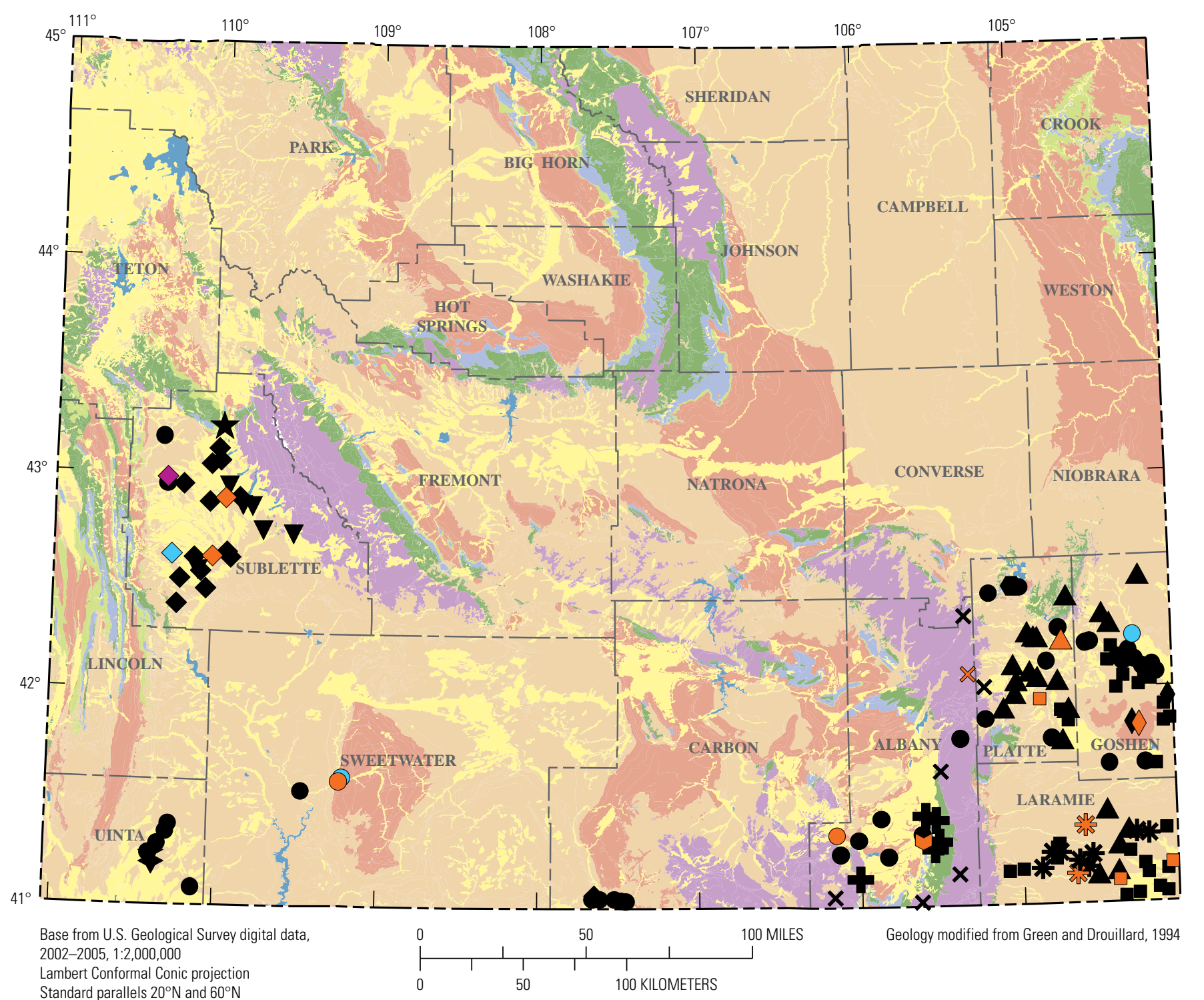

Standard parallels $20^{\circ} \mathrm{N}$ and $60^{\circ} \mathrm{N}$

Central meridian $107^{\prime} 30^{\circ} \mathrm{W}$

North American Datum of 1983

\section{EXPLANATION}

Lithostratigraphic unit

Quaternary

Tertiary

Cretaceous

Jurassic

Triassic

Paleozoic

Precambrian

Open water
Hydrogeologic unit in which well was completed-Symbol shape represents unit or aquifer

$\begin{array}{lll}\begin{array}{c}\text { Quaternary unconsolidated- } \\ \text { deposit aquifers }\end{array} & \checkmark \text { Lance aquifer } \\ \text { Bedrock aquifers } & \checkmark \text { Sundance aquifer } \\ \triangle \text { Arikaree aquifer } & \checkmark \text { Nugget aquifer } \\ \square \text { White River aquifer } & \square \text { Hartville aquifer } \\ \diamond \text { Bridger aquifer } & \bigotimes \text { Precambrian } \\ \text { aquifer }\end{array}$

$\diamond$ Wasatch aquifer

$\nabla$ Farson Sandstone-Alkali Creek aquifer
Total aluminum, in micrograms per liter-Symbol color represents concentration. Symbols are arranged by geologic age from youngest to oldest (left to right)

米 $\Delta \mathbf{a} \nabla>$ Less than detection limit $\bigcirc$

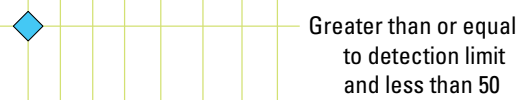

$O \sin ^{n} \triangle \square$

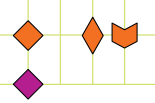

150 to less than 100

${ }^{2} 100$ to less than 5,000

35,000 to 7,330

'U.S. Environmental Protection Agency Secondary Maximum Contaminant Level (U.S. Environmental Protection Agency, 2012c).

${ }^{2}$ Wyoming Department of Environmental Quality (WDEO) Class

Special (A) fish and aquatic life groundwater standard (Wyoming Department of Environmental Quality, 2005).

${ }^{3}$ WDEO Class II agriculture groundwater standard (Wyoming Department of Environmental Quality, 2005).

Figure 18. Concentrations of total aluminum in groundwater from wells sampled for the Wyoming Groundwater-Quality Monitoring Network, November 2009 through September 2012. 


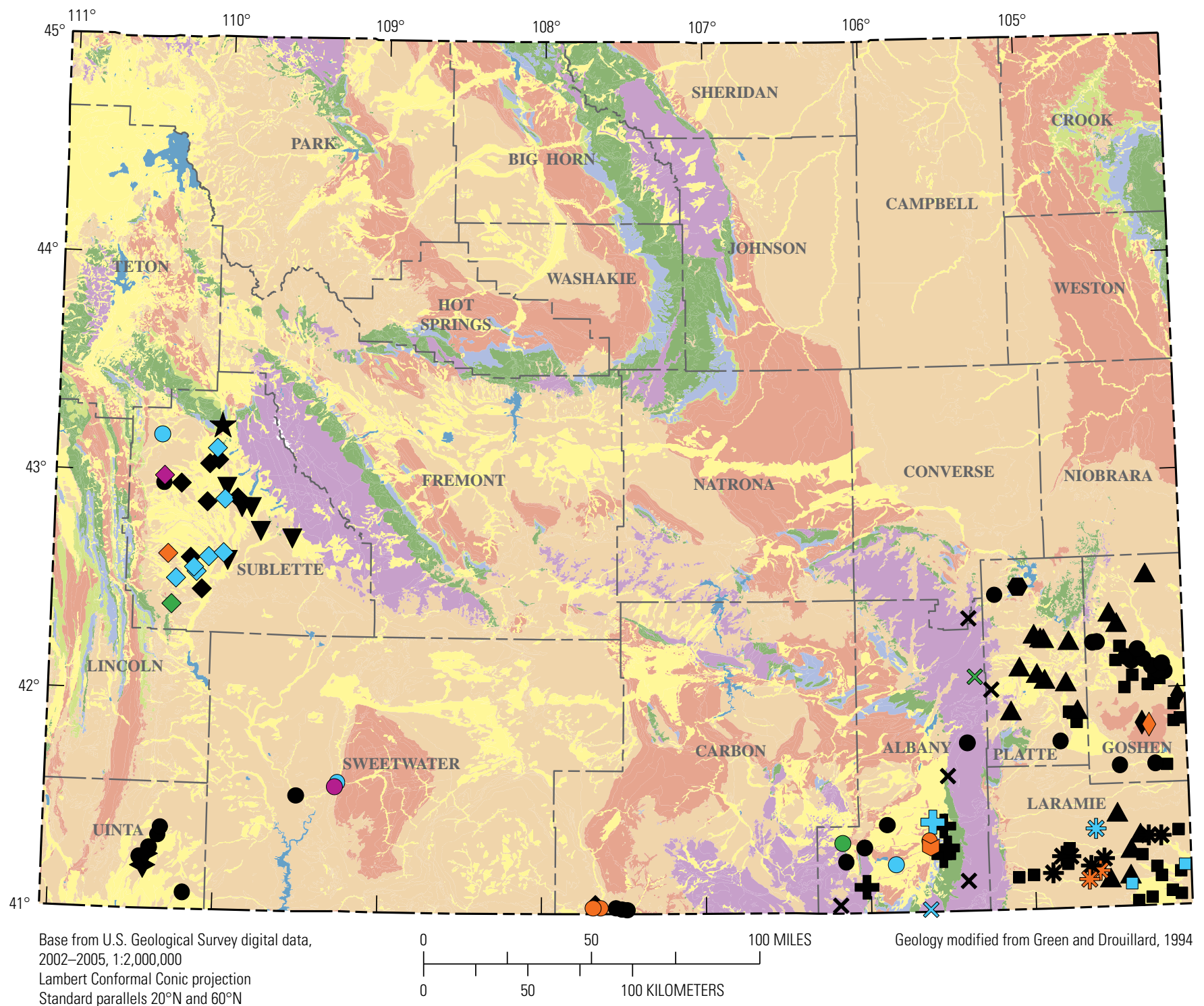

Ltandard palles $20 \mathrm{~N}^{2}$ and $60 \mathrm{~N}$

Central meridian $107^{\prime} 30^{\circ} \mathrm{W}$

North American Datum of 1983

\section{EXPLANATION}

Lithostratigraphic unit

Quaternary

Tertiary

Cretaceous

Jurassic

Triassic

Paleozoic

Precambrian

Open water

\section{Hydrogeologic unit in which well was completed-Symbol shape represents unit or aquifer}

$\bigcirc$ Quaternary unconsolidated deposit aquifers

\section{Bedrock aquifers}

Ogallala aquifer

$\triangle$ Arikaree aquifer

$\square \quad$ White River aquifer

$\diamond$ Bridger aquifer

$\diamond$ Wasatch aquifer

$\nabla$ Farson Sandstone-Alkali Creek aquifer

\section{$\diamond$ Lance aquifer \\ $\checkmark$ Sundance aquifer \\ $\hat{W}$ Nugget aquifer \\ ك Casper aquifer \\ $\square$ Hartville aquifer \\ \& Precambrian aquifer}

Total iron, in micrograms per liter-Symbol color represents concentration. Symbols are arranged by geologic age from youngest to oldest (left to right)

米 $\Delta \square>\nabla$ Less than detection limit

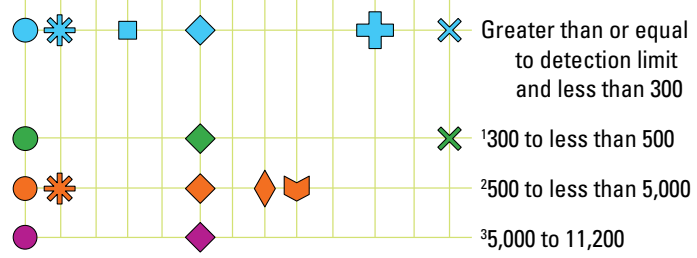

'U.S. Environmental Protection Agency Secondary Maximum Contaminant Level (U.S. Environmental Protection Agency, 2012c) and Wyoming Department of Environmental Quality (WDEQ) Class I domestic groundwater standard (Wyoming Department of Environmental Quality, 2005).

${ }^{2}$ WDEO Class Special (A) fish and aquatic life groundwater standard (Wyoming Department of Environmental Quality, 2005).

${ }^{3}$ WDEO Class II agriculture groundwater standard (Wyoming Department of Environmental Quality, 2005).

Figure 19. Concentrations of total iron in groundwater from wells sampled for the Wyoming Groundwater-Quality Monitoring Network, November 2009 through September 2012. 
Total manganese concentrations for 136 samples ranged from $<2.0$ to $2,770 \mu \mathrm{g} / \mathrm{L}$. The median manganese concentration for these samples (calculated using the log-probability regression procedure) was $0.643 \mu \mathrm{g} / \mathrm{L}$, which was less than the median manganese concentration of $7.0 \mu \mathrm{g} / \mathrm{L}$ in groundwater samples collected across the United States during 1992-2003 for the USGS NAWQA Program (Ayotte and others, 2011). The EPA SMCL and WDEQ Class I domestic groundwater-quality standard for manganese $(50 \mu \mathrm{g} / \mathrm{L})$ was exceeded in 14 samples (fig. 20). The WDEQ Class II agriculture groundwaterquality standard for manganese $(200 \mu \mathrm{g} / \mathrm{L})$ was exceeded in 7 samples. The WDEQ Class Special (A) fish and aquatic life groundwater-quality standard for manganese $(1,000 \mu \mathrm{g} / \mathrm{L})$ was exceeded in 3 samples.

Total molybdenum concentrations for 146 samples ranged from $<5.0$ to $341 \mu \mathrm{g} / \mathrm{L}$. The median molybdenum concentration for these samples (calculated using the log-probability regression procedure) was $4.22 \mu \mathrm{g} / \mathrm{L}$, which was larger than the median molybdenum concentration of $1.0 \mu \mathrm{g} / \mathrm{L}$ in groundwater samples collected across the United States during 1992-2003 for the USGS NAWQA Program (Ayotte and others, 2011). The EPA HAL for molybdenum $(40 \mu \mathrm{g} / \mathrm{L})$ was exceeded in 1 sample (fig. 21).

Groundwater samples were analyzed for total nickel, total silver, total strontium, and total thallium concentrations. Nickel concentrations for 146 samples ranged from $<0.19$ to $35.8 \mu \mathrm{g} / \mathrm{L}$. The median nickel concentration for these samples (calculated using the log-probability regression procedure) was $0.191 \mu \mathrm{g} / \mathrm{L}$, which was less than the median nickel concentration of $1.1 \mu \mathrm{g} / \mathrm{L}$ in groundwater samples collected across the United States during 1992-2003 for the USGS NAWQA Program (Ayotte and others, 2011). Silver concentrations for 146 samples ranged from $<0.015$ to E2.10 $\mu \mathrm{g} / \mathrm{L}$. A median silver concentration could not be calculated for these samples using the log-probability regression procedure because too many values were censored. Silver concentrations generally are small in groundwater, as indicated by a median concentration of $<1.0 \mu \mathrm{g} / \mathrm{L}$ reported for groundwater samples collected across the United States during 1992-2003 for the USGS NAWQA Program (Ayotte and others, 2011).

Strontium concentrations for 146 samples ranged from 19.8 to $12,900 \mu \mathrm{g} / \mathrm{L}$. The median strontium concentration for these samples was $435 \mu \mathrm{g} / \mathrm{L}$, which was larger than the median strontium concentration of $270 \mu \mathrm{g} / \mathrm{L}$ in groundwater samples collected across the United States during 1992-2003 for the USGS NAWQA Program (Ayotte and others, 2011). Thallium concentrations for 146 samples ranged from $<0.06$ to E1.60 $\mu \mathrm{g} / \mathrm{L}$. The median thallium concentration for these samples (calculated using the log-probability regression procedure) was $0.126 \mu \mathrm{g} / \mathrm{L}$, which is the same magnitude as the median thallium concentration of $<1.0 \mu \mathrm{g} / \mathrm{L}$ in groundwater samples collected across the United States during 1992-2003 for the USGS NAWQA Program (Ayotte and others, 2011).

Groundwater samples were analyzed for total vanadium and total zinc concentrations. Vanadium concentrations for 146 samples ranged from $<10$ to $84.7 \mu \mathrm{g} / \mathrm{L}$. The median vanadium concentration for these samples (calculated using the logprobability regression procedure) was $4.94 \mu \mathrm{g} / \mathrm{L}$, which was larger than the median vanadium concentration of $1.4 \mu \mathrm{g} / \mathrm{L}$ in groundwater samples collected across the United States during 1992-2003 for the USGS NAWQA Program (Ayotte and others, 2011). Zinc concentrations for 146 samples ranged from $<2.0$ to $178 \mu \mathrm{g} / \mathrm{L}$. The median zinc concentration for these samples (calculated using the log-probability regression procedure) was $3.03 \mu \mathrm{g} / \mathrm{L}$, which was less than the median zinc concentration of $4.8 \mu \mathrm{g} / \mathrm{L}$ in groundwater samples collected across the United States during 1992-2003 for the USGS NAWQA Program (Ayotte and others, 2011).

Metalloids of total antimony, total arsenic, total boron, and total selenium concentrations were analyzed in 146 samples collected for the WGQMN. Antimony concentrations for 146 samples ranged from $<0.18$ to $1.3 \mu \mathrm{g} / \mathrm{L}$. A median antimony concentration could not be calculated for these samples using the log-probability regression procedure because too many values were censored. Median antimony concentrations generally are small in groundwater, as indicated by a median concentration of $<1.0 \mu \mathrm{g} / \mathrm{L}$ in groundwater samples collected across the United States during 1992-2003 for the USGS NAWQA Program (Ayotte and others, 2011). Arsenic concentrations for 146 samples ranged from $<4.0$ to $32.7 \mu \mathrm{g} / \mathrm{L}$. The median arsenic concentration for these samples (calculated using the log-probability regression procedure) was $1.94 \mu \mathrm{g} / \mathrm{L}$, which was larger than the median arsenic concentration of $0.79 \mu \mathrm{g} / \mathrm{L}$ in groundwater samples collected across the United States during 1992-2003 for the USGS NAWQA Program (Ayotte and others, 2011). The EPA MCL for arsenic (10 $\mu \mathrm{g} / \mathrm{L})$ was exceeded in 7 samples (fig. 22). Boron concentrations for 146 samples ranged from 32.4 to $6,610 \mu \mathrm{g} / \mathrm{L}$. The median boron concentration for these samples (calculated using the log-probability regression procedure) was $81.5 \mu \mathrm{g} / \mathrm{L}$, which was larger than the median boron concentration of $35 \mu \mathrm{g} / \mathrm{L}$ in groundwater samples collected across the United States during 1992-2003 for the USGS NAWQA Program (Ayotte and others, 2011). The EPA HAL for boron $(6,000 \mu \mathrm{g} / \mathrm{L})$ was exceeded in 1 sample (fig. 23). The WDEQ Class I domestic and WDEQ Class II agriculture groundwater-quality standards for boron (750 $\mu \mathrm{g} / \mathrm{L}$ ) were exceeded in 5 samples. The WDEQ Class III livestock groundwater-quality standard for boron $(5,000 \mu \mathrm{g} / \mathrm{L})$ was exceeded in 1 sample. Selenium concentrations for 146 samples ranged from $<0.10$ to E207 $\mu \mathrm{g} / \mathrm{L}$. The median selenium concentration for these samples (calculated using the log-probability regression procedure) was $0.909 \mu \mathrm{g} / \mathrm{L}$, which was larger than the median selenium concentration of $0.34 \mu \mathrm{g} / \mathrm{L}$ in groundwater samples collected across the United States during 1992-2003 for the USGS NAWQA Program (Ayotte and others, 2011). The WDEQ Class II agriculture groundwater-quality standard for selenium $(20 \mu \mathrm{g} / \mathrm{L})$ was exceeded in 5 samples (fig. 24). The EPA MCL, WDEQ Class I domestic groundwater-quality standard, WDEQ Class III livestock groundwater-quality standard, and WDEQ Class Special (A) fish and aquatic life groundwater-quality standard for selenium (50 $\mu \mathrm{g} / \mathrm{L})$ were exceeded in 3 samples. 


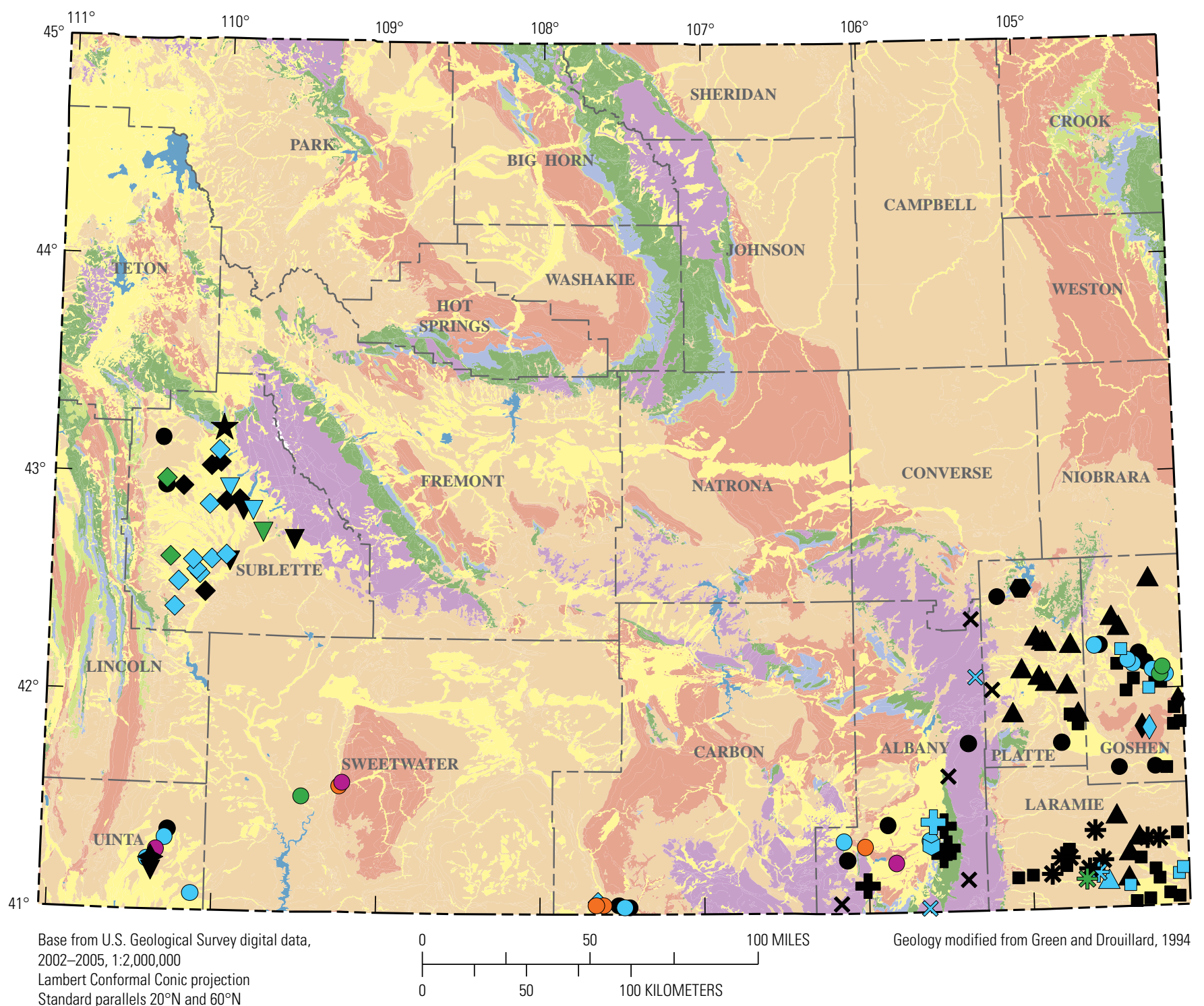

Standard parallels $20^{\circ} \mathrm{N}$ and $60 \mathrm{~N}$

Central meridian $107^{\prime} 30^{\circ} \mathrm{W}$

North American Datum of 1983

\section{EXPLANATION}

Lithostratigraphic unit

Hydrogeologic unit in which well was completed-Symbol shape represents unit or aquifer

Quaternary

Tertiary

Cretaceous

Quaternary unconsolidateddeposit aquifers

\section{Bedrock aquifers}

Jurassic

Triassic

Paleozoic

Precambrian

Open water

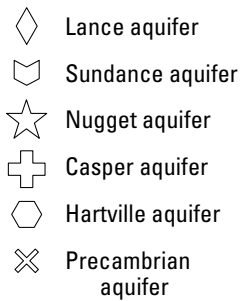

aquifer

\section{Nh Ogallala aquifer}

$\triangle$ Arikaree aquifer

$\square \quad$ White River aquifer

$\curvearrowright$ Bridger aquifer

$\diamond$ Wasatch aquifer

$\nabla$ Farson Sandstone-Alkali Creek aquifer
Total manganese, in micrograms per liter-Symbol color represents concentration. Symbols are arranged by geologic age from youngest to oldest (left to right)

兴

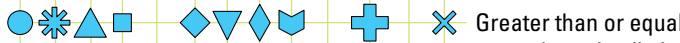

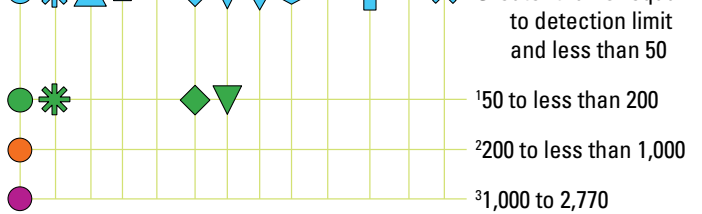

'U.S. Environmental Protection Agency Secondary Maximum Contaminant Level (U.S. Environmental Protection Agency, 2012c) and Wyoming Department of Environmental Quality (WDEQ) Class I domestic groundwater standard (Wyoming Department of Environmental Quality, 2005).

${ }^{2}$ WDEO Class II agriculture groundwater standard (Wyoming Department of Environmental Quality, 2005).

${ }^{3}$ WDEO Class Special (A) fish and aquatic life groundwater standard

(Wyoming Department of Environmental Quality, 2005).

Figure 20. Concentrations of total manganese in groundwater from wells sampled for the Wyoming Groundwater-Quality Monitoring Network, November 2009 through September 2012. 


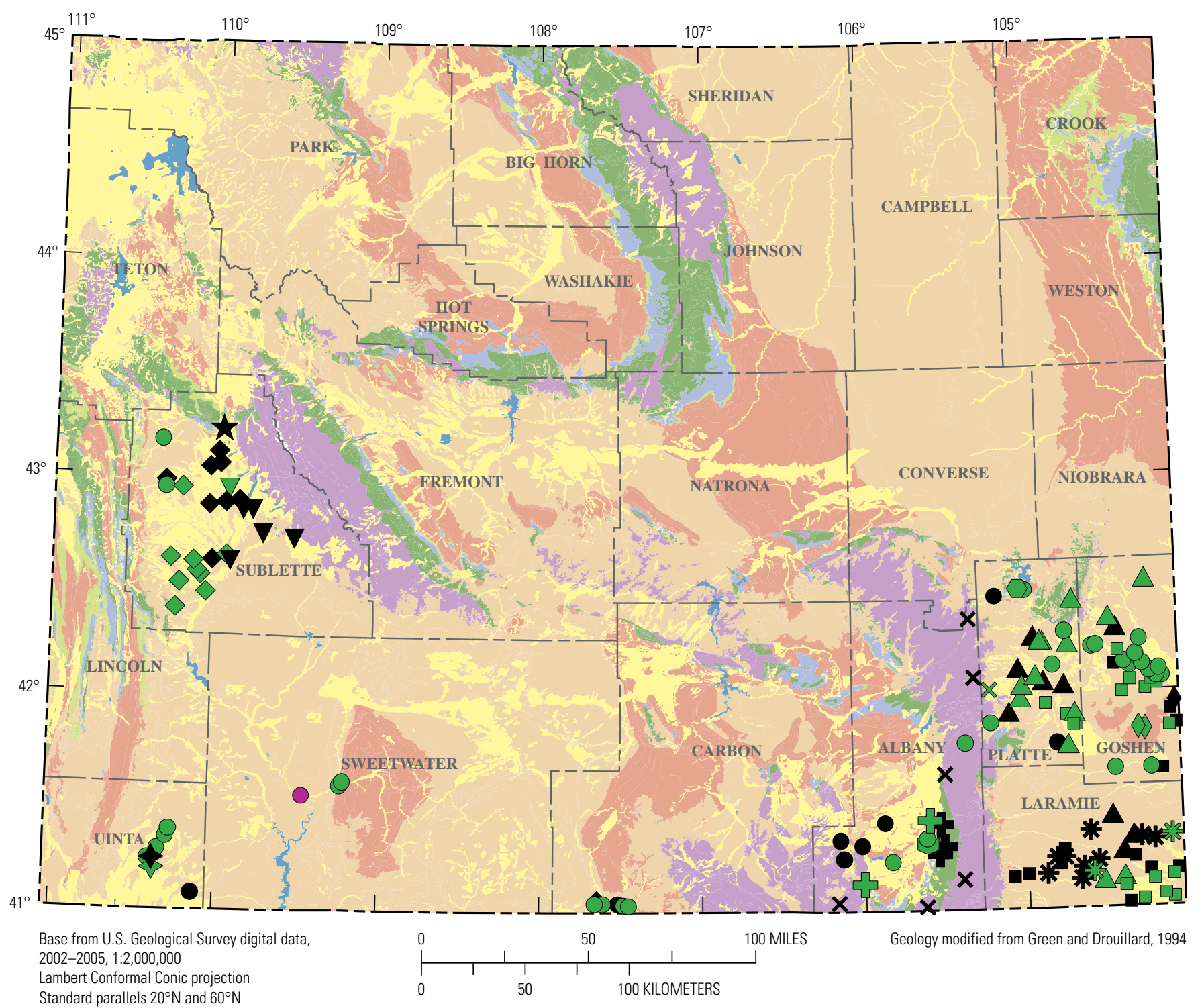

Standard parallels $20^{\circ} \mathrm{N}$ and $60^{\circ} \mathrm{N}$

Central meridian $107^{\prime} 30^{\circ} \mathrm{W}$

North American Datum of 1983

\section{EXPLANATION}

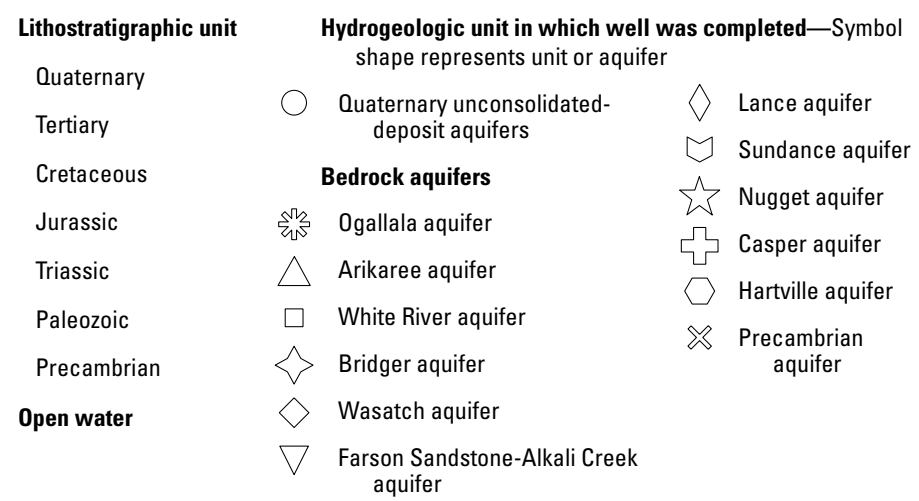

Total molybdenum, in micrograms per liter-Symbol color represents concentration. Symbols are arranged by geologic age from youngest to oldest (left to right)

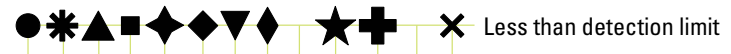

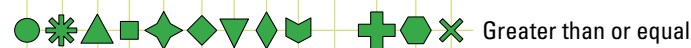
to detection limit and less than 40

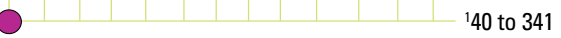

'U.S. Environmental Protection Agency Lifetime Health Advisory Level (U.S. Environmental Protection Agency, 2012c).

Figure 21. Concentrations of total molybdenum in groundwater from wells sampled for the Wyoming Groundwater-Quality Monitoring Network, November 2009 through September 2012. 


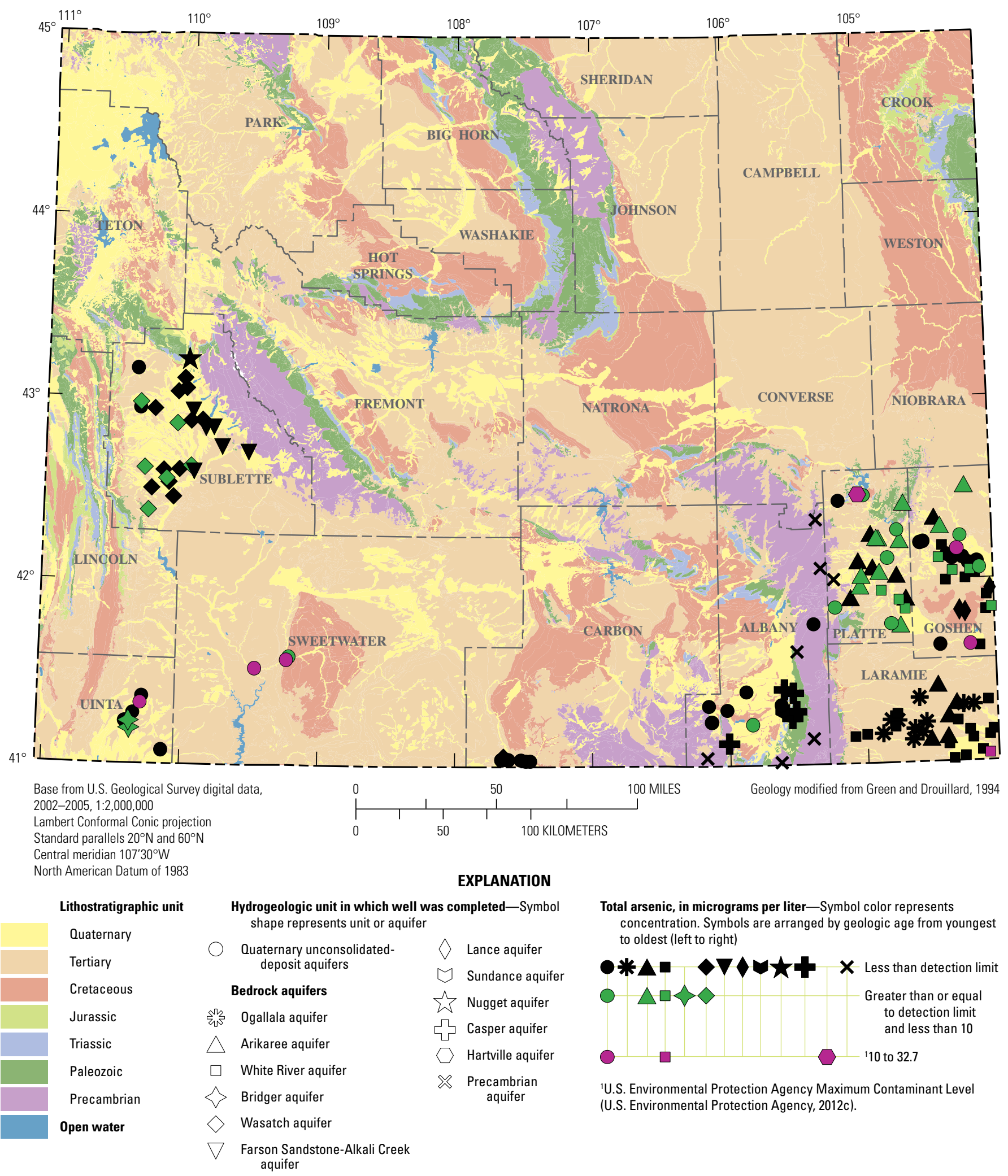

Figure 22. Concentrations of total arsenic in groundwater from wells sampled for the Wyoming Groundwater-Quality Monitoring Network, November 2009 through September 2012. 


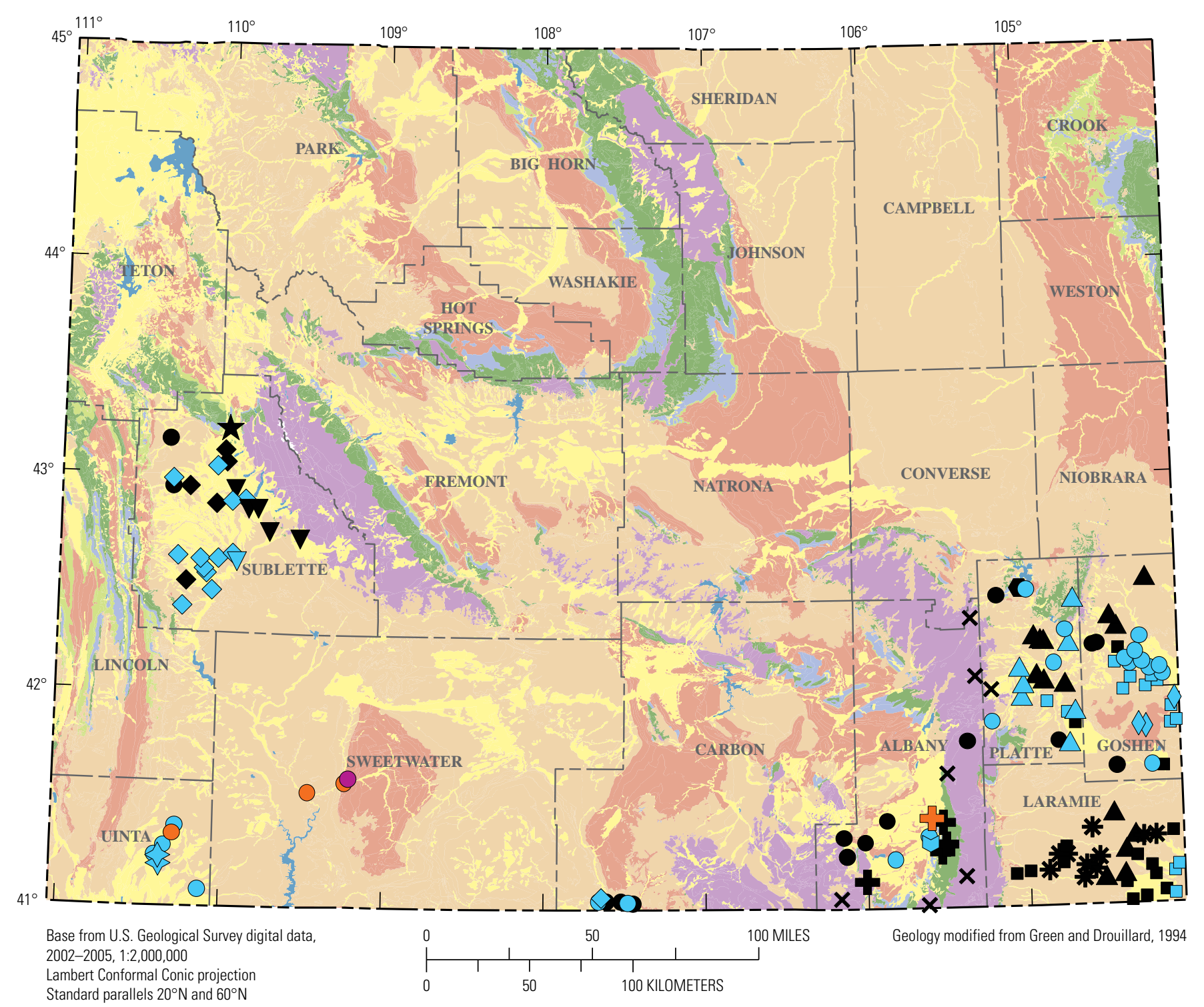

Standard parallels $20^{\circ} \mathrm{N}$ and $60^{\circ} \mathrm{N}$

Central meridian $107^{\prime} 30^{\circ} \mathrm{W}$

North American Datum of 1983

\section{EXPLANATION}

Lithostratigraphic unit

Quaternary

Tertiary

Cretaceous

Jurassic

Triassic

Paleozoic

Precambrian

Open water
Hydrogeologic unit in which well was completed-Symbol shape represents unit or aquifer

Quaternary unconsolidateddeposit aquifers

\section{Bedrock aquifers}

Ogallala aquifer

$\triangle$ Arikaree aquifer

$\square \quad$ White River aquifer

$\Leftrightarrow$ Bridger aquifer

$\diamond$ Wasatch aquifer

$\nabla$ Farson Sandstone-Alkali Creek aquifer

द Casper aquifer

$\checkmark$ Hartville aquifer

\& Precambrian aquifer
Total boron, in micrograms per liter-Symbol color represents concentration. Symbols are arranged by geologic age from youngest to oldest (left to right)

米 口 $\triangle \Delta \diamond \diamond \nabla \diamond \square$

Greater than or equal to detection limit and less than 750

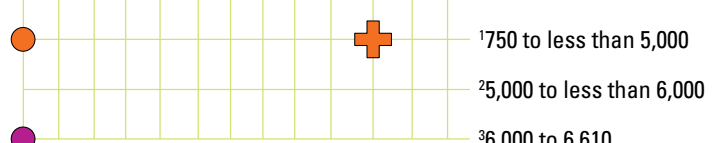

'Wyoming Department of Environmental Quality (WDEQ) Class I domestic and Class II agriculture groundwater standards (Wyoming Department of Environmental Quality, 2005).

${ }^{2}$ WDEO Class III livestock groundwater standard (Wyoming Department of Environmental Quality, 2005).

${ }^{3}$ U.S. Environmental Protection Agency Draft Health Advisory Level (U.S. Environmental Protection Agency, 2012c).

Figure 23. Concentrations of total boron in groundwater from wells sampled for the Wyoming Groundwater-Quality Monitoring Network, November 2009 through September 2012. 


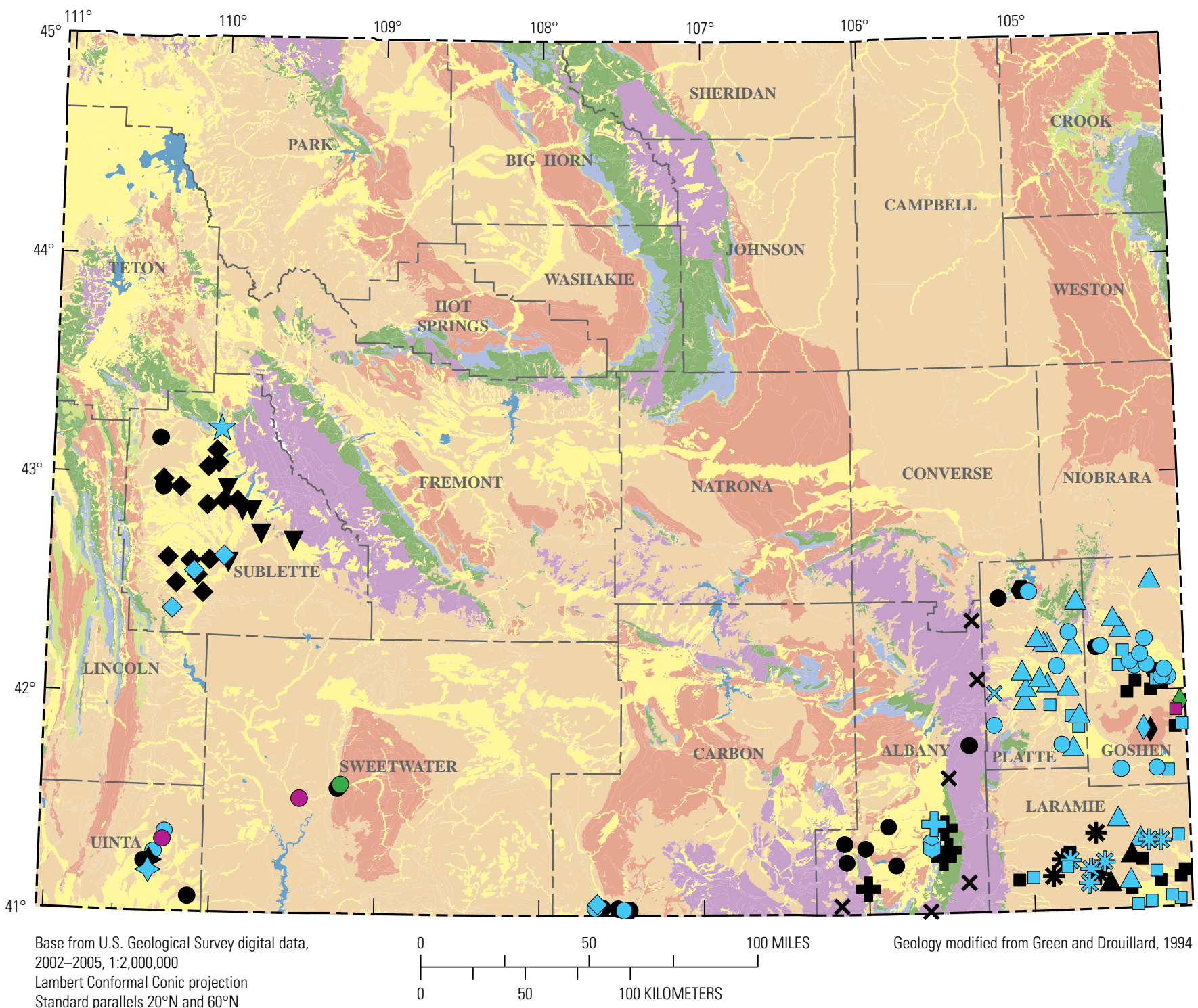

Standard parallels $20^{\circ} \mathrm{N}$ and $60^{\circ} \mathrm{N}$

Central meridian $107^{\prime} 30^{\circ} \mathrm{W}$

North American Datum of 1983

\section{EXPLANATION}

Lithostratigraphic unit

Quaternary

Tertiary

Cretaceous

Jurassic

Triassic

Paleozoic

Precambrian

Open water

$\begin{gathered}\text { Hydrogeologic unit in which well was completed-Symbol } \\ \text { shape represents unit or aquifer }\end{gathered}$
$\begin{gathered}\text { Quaternary unconsolidated- } \\ \text { deposit aquifers }\end{gathered}$
Bedrock aquifers

Hydrogeologic unit in which well was completed-Symbol

Total selenium, in micrograms per liter-Symbol color represents concentration. Symbols are arranged by geologic age from youngest to oldest (right)

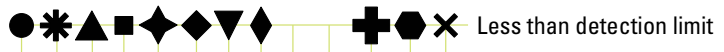

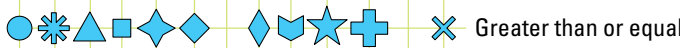
to detection limit
and less than 20

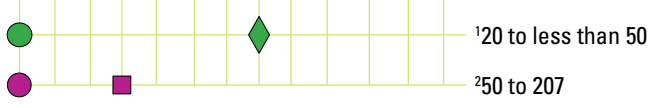

'Wyoming Department of Environmental Quality (WDEQ) Class II agriculture groundwater standard (Wyoming Department of Environmental Quality, 2005).

${ }^{2}$ U.S. Environmental Protection Agency Maximum Contaminant Level (U.S. Environmental Protection Agency, 2012c) and WDEO Class I domestic, Class III livestock, and Class Special (A) fish and aquatic life groundwater standards (Wyoming Department of Environmental Quality, 2005).

Figure 24. Concentrations of total selenium in groundwater from wells sampled for the Wyoming Groundwater-Quality Monitoring Network, November 2009 through September 2012. 


\section{Nutrients and Dissolved Organic Carbon}

Nutrients are species of nitrogen and phosphorus that occur naturally in groundwater in low concentrations, but high concentrations are usually associated with human activities (Bartos and others, 2004). Major sources of nutrients include fertilizers, runoff from feedlots and manure piles, leaking septic tanks, and sewage (Eddy-Miller and Blain, 2011). Concentrations of dissolved ammonia, dissolved nitrite, dissolved nitrate, dissolved orthophosphate, and dissolved organic carbon from the water-quality data collected for the WGQMN were statistically summarized (table 5). Individual analyses for these constituents, as well as results for additional nutrient constituents that were analyzed in some samples, also are presented (table 1-5). Concentrations of nutrients in groundwater samples collected for the WGQMN are compared to national background concentrations measured in groundwater samples collected during 1992-2004 for the USGS NAWQA Program in this section of the report.

Dissolved ammonia concentrations for 140 samples ranged from $<0.010$ to $0.405 \mathrm{mg} / \mathrm{L}$ as nitrogen. The median ammonia concentration for these samples (calculated using the log-probability regression procedure) was $0.005 \mathrm{mg} / \mathrm{L}$, which was less than the median ammonia concentration of $0.10 \mathrm{mg} / \mathrm{L}$ in groundwater samples collected across the United States during 1992-2004 for the USGS NAWQA Program (Dubrovsky and others, 2010).

Dissolved nitrite concentrations for 140 samples ranged from $<0.001$ to $1.20 \mathrm{mg} / \mathrm{L}$. A median nitrite concentration could not be calculated for these samples using the logprobability regression procedure because too many values were censored. An estimated national background concentration of nitrite was not calculated in groundwater samples collected across the United States during 19922004 for the USGS NAWQA Program (Dubrovsky and others, 2010). The EPA MCL and WDEQ Class I domestic groundwater-quality standard for nitrite $(1.0 \mathrm{mg} / \mathrm{L})$ were exceeded in 1 sample (fig. 25).

Dissolved nitrate concentrations for 140 samples ranged from $<0.005$ to $63.5 \mathrm{mg} / \mathrm{L}$. The median nitrate concentration for these samples (calculated using the log-probability regression procedure) was $1.35 \mathrm{mg} / \mathrm{L}$ in groundwater samples, which was larger than the median nitrate concentration of $1.0 \mathrm{mg} / \mathrm{L}$ in groundwater samples collected across the United States during 1992-2004 for the USGS NAWQA Program (Dubrovsky and others, 2010). Concentrations of nitrate in groundwater greater than $1 \mathrm{mg} / \mathrm{L}$ (Nolan and Hitt, 2003) have been attributed to human activities. Nitrate concentrations in about one-half of the samples (74 of 140) exceeded $1 \mathrm{mg} / \mathrm{L}$. The EPA MCL and WDEQ Class I domestic groundwaterquality standard for nitrate $(10 \mathrm{mg} / \mathrm{L})$ were exceeded in 4 samples (fig. 26). Infants that drink water containing nitrate in excess of the EPA MCL could become ill or die (U.S. Environmental Protection Agency, 2013a).

Dissolved orthophosphate concentrations for 140 samples ranged from $<0.005$ to $1.50 \mathrm{mg} / \mathrm{L}$. The median orthophosphate concentration for these samples (calculated using the logprobability regression procedure) was $0.045 \mathrm{mg} / \mathrm{L}$, which was larger than the median ammonia concentration of $0.030 \mathrm{mg} / \mathrm{L}$ in groundwater samples collected across the United States during 1992-2004 for the USGS NAWQA Program (Dubrovsky and others, 2010).

The DOC concentrations for 146 samples ranged from $<0.15$ to $67.4 \mathrm{mg} / \mathrm{L}$, with a median concentration for these samples of $1.43 \mathrm{mg} / \mathrm{L}$. An estimated national background concentration of DOC was not calculated in groundwater samples collected across the United States during 1992-2004 for the USGS NAWQA Program (Dubrovsky and others, 2010). 


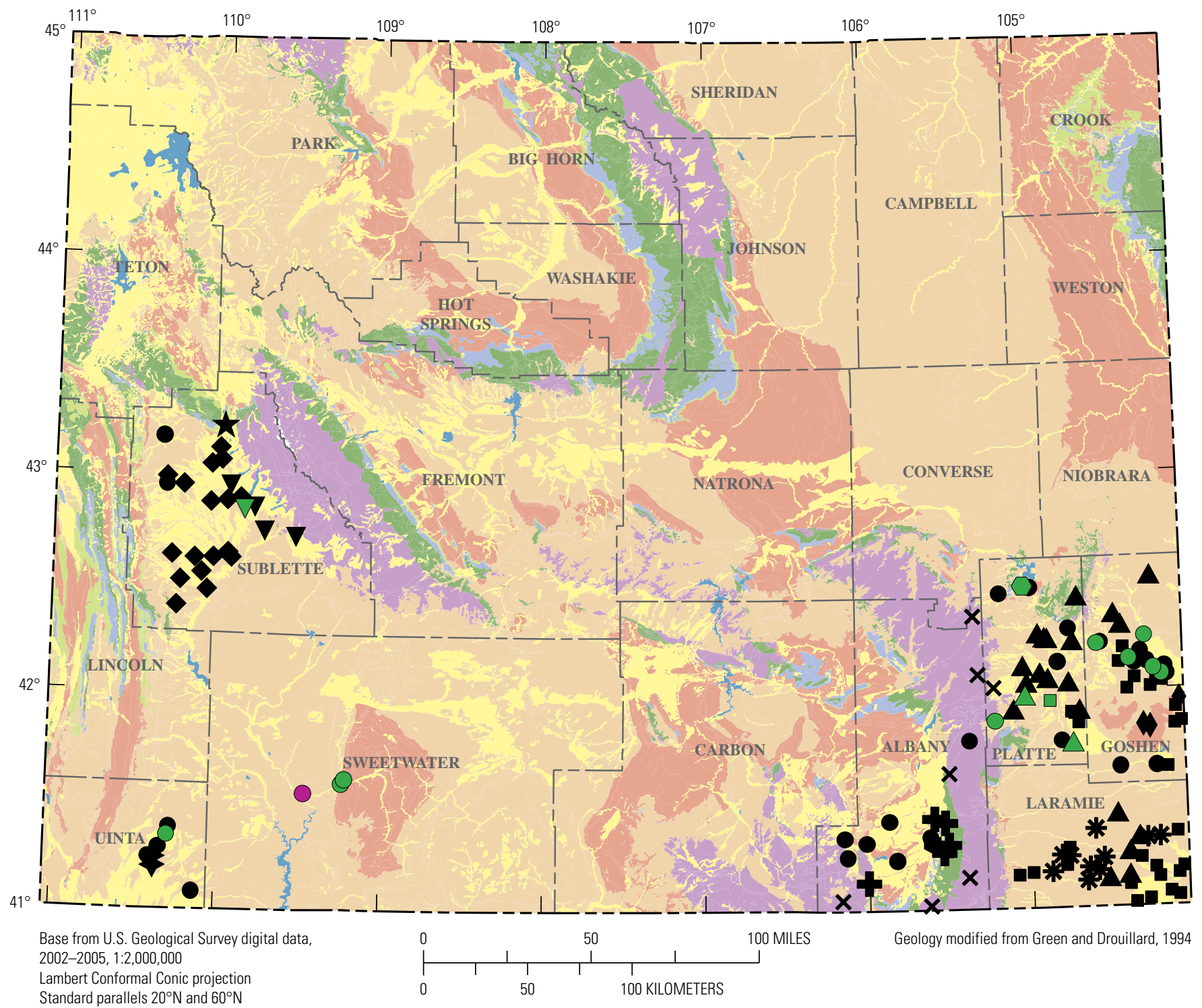

Standard parallels $20^{\circ} \mathrm{N}$ and $60^{\circ} \mathrm{N}$

Central meridian $107^{\prime} 30^{\circ} \mathrm{W}$

North American Datum of 1983

\section{EXPLANATION}

Lithostratigraphic unit Hydrogeologic unit in which well was completed-Symbol shape represents unit or aquifer

Quaternary

Tertiary

Cretaceous

$\bigcirc$ Quaternary unconsolidateddeposit aquifers

\section{Bedrock aquifers}

Jurassic

Triassic

Ogallala aquifer

Paleozoic

$\triangle$ Arikaree aquifer

Precambrian

$\square \quad$ White River aquifer

Open water $\diamond$ Bridger aquifer

$\diamond$ Wasatch aquifer

$\nabla \quad \begin{gathered}\text { Farson Sandstone-Alkali Creek } \\ \text { aquifer }\end{gathered}$
Dissolved nitrite, as nitrogen, in milligrams per liter-Symbol color represents concentration. Symbols are arranged by geologic age from youngest to oldest (right)

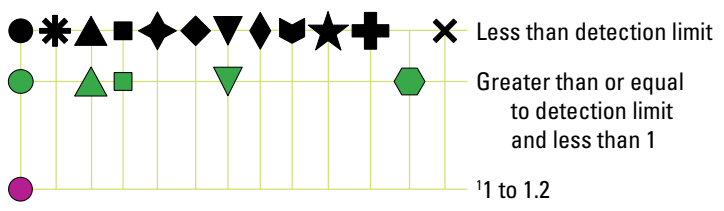

'U.S. Environmental Protection Agency Maximum Contaminant Level (U.S. Environmental Protection Agency, 2012c) and Wyoming Department of Environmental Quality Class I Domestic groundwater standard (Wyoming Department of Environmental Quality, 2005).

Figure 25. Concentrations of dissolved nitrite in groundwater from wells sampled for the Wyoming Groundwater-Quality Monitoring Network, November 2009 through September 2012. 


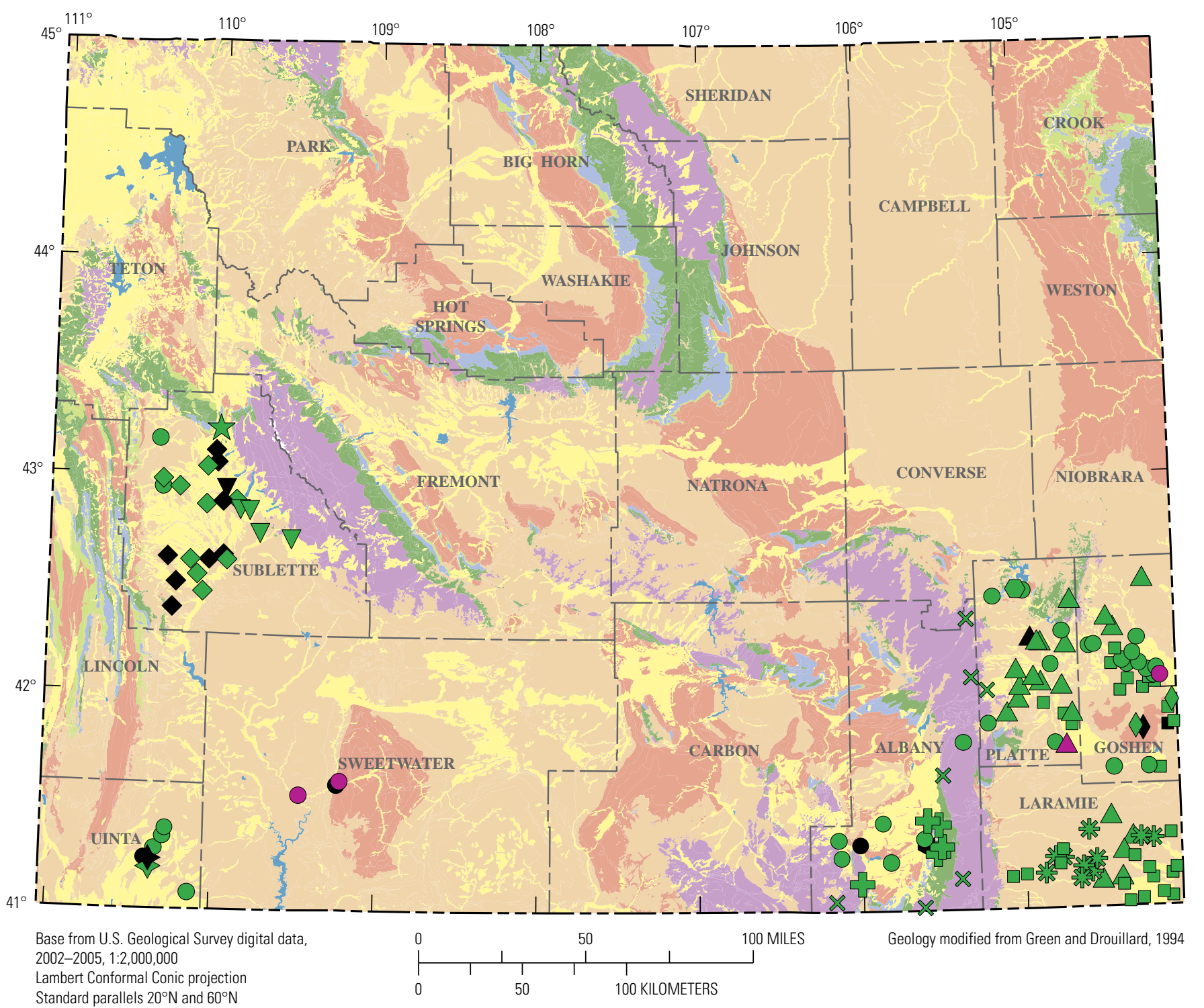

Central meridian $107^{\prime} 30^{\circ} \mathrm{W}$

North American Datum of 1983

\section{EXPLANATION}

Lithostratigraphic unit

Quaternary

Tertiary

Cretaceous

Jurassic

Triassic

Paleozoic

Precambrian

Open water

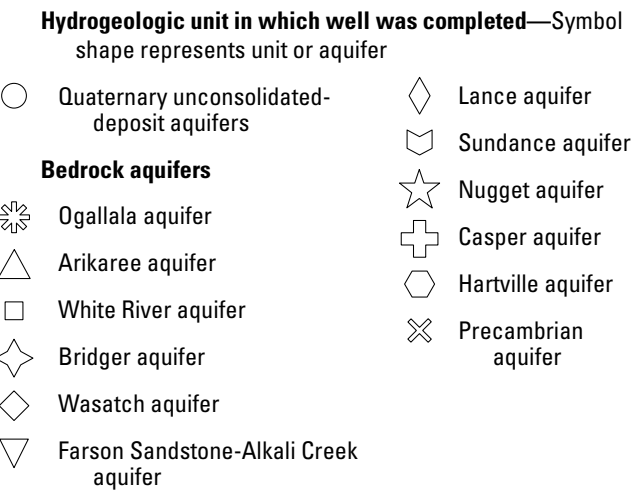

Dissolved nitrate, as nitrogen, in milligrams per liter-Symbol color represents concentration. Symbols are arranged by geologic age from youngest to oldest (left to right)

Less than detection limit

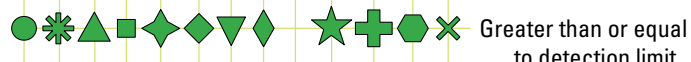
to detection limit 10 to 63.5

'U.S. Environmental Protection Agency Maximum Contaminant Level (U.S. Environmental Protection Agency, 2012c) and Wyoming Department of Environmental Quality Class I domestic groundwater standard (Wyoming Department of Environmental Quality, 2005).

Figure 26. Concentrations of dissolved nitrate in groundwater from wells sampled for the Wyoming Groundwater-Quality Monitoring Network, November 2009 through September 2012. 


\section{Radionuclides}

A statistical summary of radionuclides from the waterquality samples collected for the WGQMN is reported in table 5. Results from individual analyses are presented in table 1-6. A nuclide is a general term applicable to all atomic forms of an element. Nuclides are characterized by the number of protons and neutrons in the nucleus, as well as by the amount of energy contained within the atom. A radionuclide is an atom with an unstable nucleus that emits energy in the form of rays or high-speed particles to become more stable (U.S. Environmental Protection Agency, 2013b). The radioactive decay process releases ionizing radiation, which is composed of alpha particles, beta particles, or gamma rays.

Radionuclides have unique specific reporting requirements related to each sample analyzed. Radionuclides are reported in relation to a sample-specific critical level (ssLc) plus or minus $( \pm$ ) a 1-sigma combined standard uncertainty (csu). The ssLc is the smallest measured concentration that is statistically different from the instrument background or analytical blank for a single sample, whereas the csu is the square root of a sum of variances and can be considered the standard deviation of a single radiological value (McCurdy and others, 2008). Values less than the ssLc are reported as nondetections and are denoted with an " $\mathrm{R}$ " before the value (tables 5 and 1-6).

Radioactivity describes a group of processes by which matter and energy are released from the nucleus of atoms as an alpha particle, a beta particle, or a gamma ray (McCurdy and others, 2008). Alpha particles do not penetrate the skin and are hazardous to internal organs only when inhaled or ingested (U.S. Environmental Protection Agency, 1999a). Beta particles can penetrate the skin, and emissions from strong sources can redden or even burn the skin; however, exposure through inhalation or ingestion is the greatest concern (U.S. Environmental Protection Agency, 2012a). The greatest risk to human health in general comes from a lifetime of exposure to radionuclides (U.S. Environmental Protection Agency, 1999a); health hazards from short-term exposure generally are negligible. The EPA drinking water MCLs for exposure to radioactivity represent about a 1 in 10,000 risk of developing a fatal cancer over a lifetime of 70 years when consuming 2 liters (about 0.5 gallon) of water per day (U.S. Environmental Protection Agency, 2000).

Gross alpha radioactivity for 12 samples ranged from $1.05 \pm 0.71$ to $136 \pm 22$ picocuries per liter ( $\mathrm{pCi} / \mathrm{L}$ ), with a median activity of $4.35 \mathrm{pCi} / \mathrm{L}$. The EPA MCL for gross alpha radioactivity $(15 \mathrm{pCi} / \mathrm{L})$ was exceeded in 2 samples. Gross beta radioactivity for 12 samples ranged from R0.604 \pm 0.55 to $74.6 \pm 9.0 \mathrm{pCi} / \mathrm{L}$, with a median activity of $3.90 \mathrm{pCi} / \mathrm{L}$.

The source of radon in groundwater is naturally occurring uranium in rock and sediments. Radon occurs as a gas that can be dissolved in water and ingested, but inhalation is the primary method of exposure (U.S. Environmental Protection Agency, 2013b). Radon gas dissolved in water can be released indoors when one showers or washes, but the main source of radon emission to indoor air is the decay of uranium in soils and rocks underlying buildings (U.S. Environmental Protection Agency, 2013b). Radon is the second leading cause of lung cancer in the United States (Cothern and Smith, 1987). Although an MCL for radon has not been set by EPA for public drinking-water supplies, an MCL of 4,000 pCi/L has been proposed by EPA for radon in water from public water-supply systems if statewide multimedia mitigation programs are established to address radon in indoor air (U.S. Environmental Protection Agency, 1999b). An alternative MCL of $300 \mathrm{pCi} / \mathrm{L}$ for radon has been proposed by EPA for systems that choose not to develop multimedia mitigation programs (U.S. Environmental Protection Agency, 1999b). Radon concentrations for 14 samples ranged from R8.9 \pm 8.3 to $3,620 \pm 200 \mathrm{pCi} / \mathrm{L}$. The median radon concentration for these samples was $670 \mathrm{pCi} / \mathrm{L}$, which is larger than the median radon concentration of $430 \mathrm{pCi} / \mathrm{L}$ in groundwater samples collected across the United States during 1992-2003 for the USGS NAWQA Program (Ayotte and others, 2011). The EPA alternative MCL for radon (300 pCi/L) was exceeded in 12 samples (fig. 27).

Uranium is sometimes present in the rocks and minerals composing an aquifer and can leach into the groundwater. Naturally occurring uranium is found as three isotopes (uranium-238, uranium-235, and uranium-234). Groundwater samples were analyzed for total uranium. Total uranium concentrations for 146 samples ranged from $<0.10$ to $209 \mu \mathrm{g} / \mathrm{L}$. The median uranium concentration (calculated using the log-probability regression procedure) for these samples was $7.25 \mu \mathrm{g} / \mathrm{L}$, which is larger than the median uranium concentration of $0.52 \mu \mathrm{g} / \mathrm{L}$ in groundwater samples collected across the United States during 1992-2003 for the USGS NAWQA Program (Ayotte and others, 2011). The EPA MCL and WDEQ Class Special (A) fish and aquatic life groundwater-quality standard for uranium (30 $\mu \mathrm{g} / \mathrm{L})$ were exceeded in 16 samples (fig. 28). 


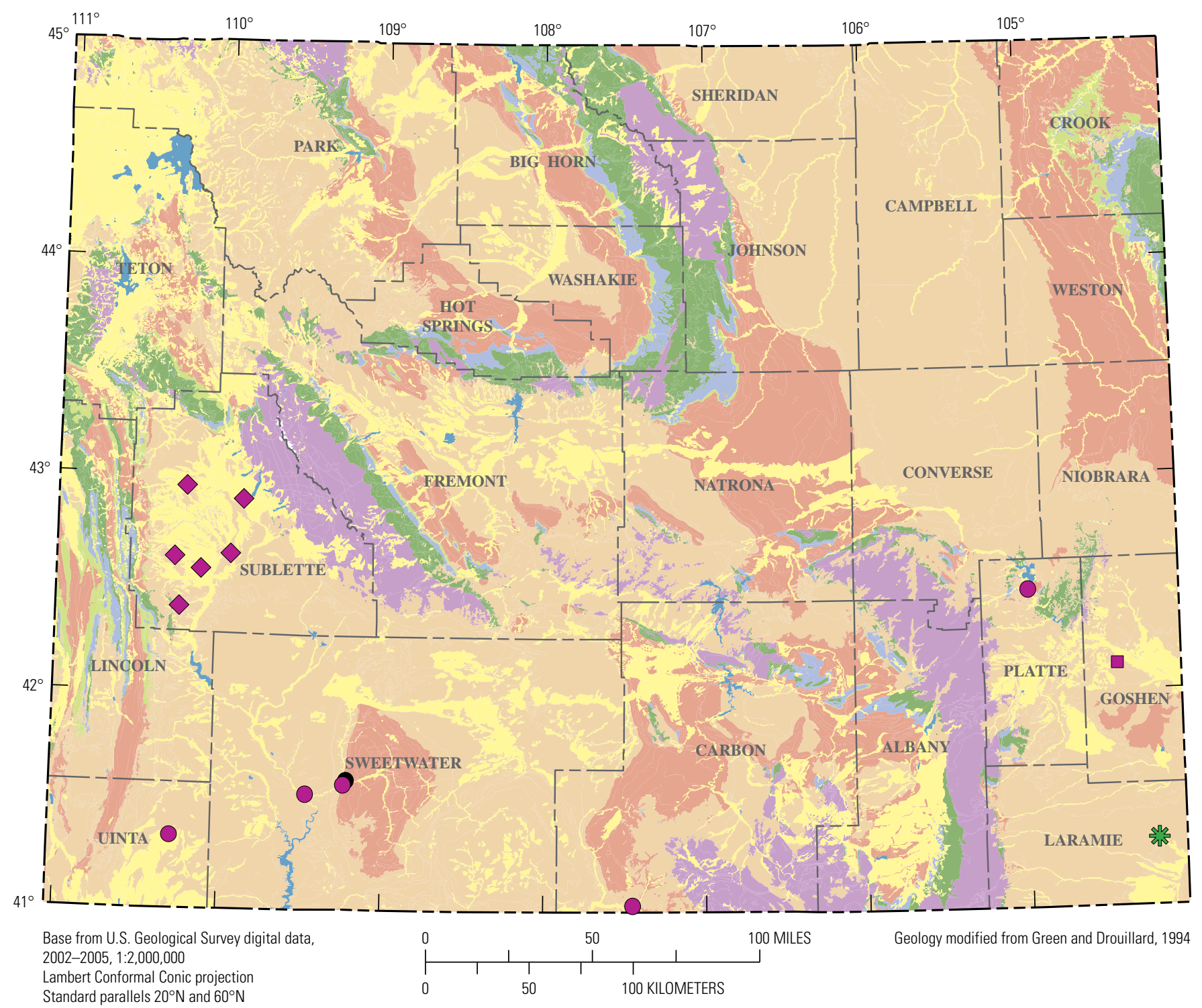

Standard parallels $20^{\circ} \mathrm{N}$ and $60^{\circ} \mathrm{N}$

Central meridian $107^{\prime} 30^{\circ} \mathrm{W}$

North American Datum of 1983

EXPLANATION

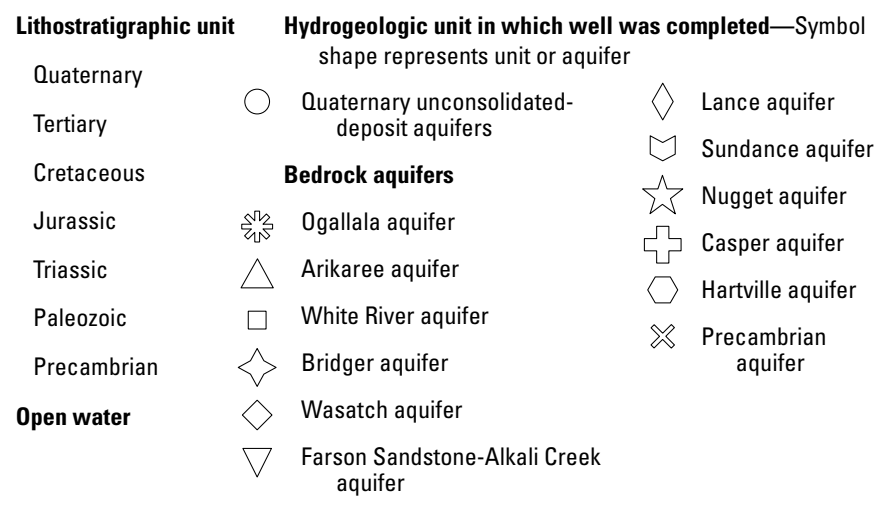

Radon, in picocuries per liter-Symbol color represents activity. Symbols are arranged by geologic age from youngest to oldest (left to right)

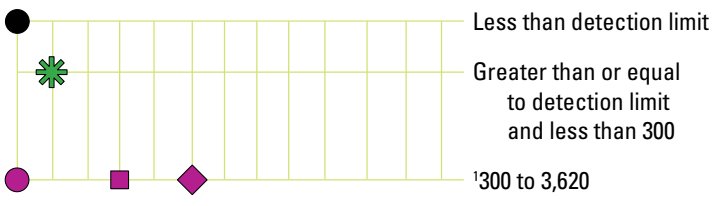

'U.S. Environmental Protection Agency Proposed Maximum Contaminant Level (U.S. Environmental Protection Agency, 2012c).

Figure 27. Concentrations of radon in groundwater from wells sampled for the Wyoming Groundwater-Quality Monitoring Network, November 2009 through September 2012. 


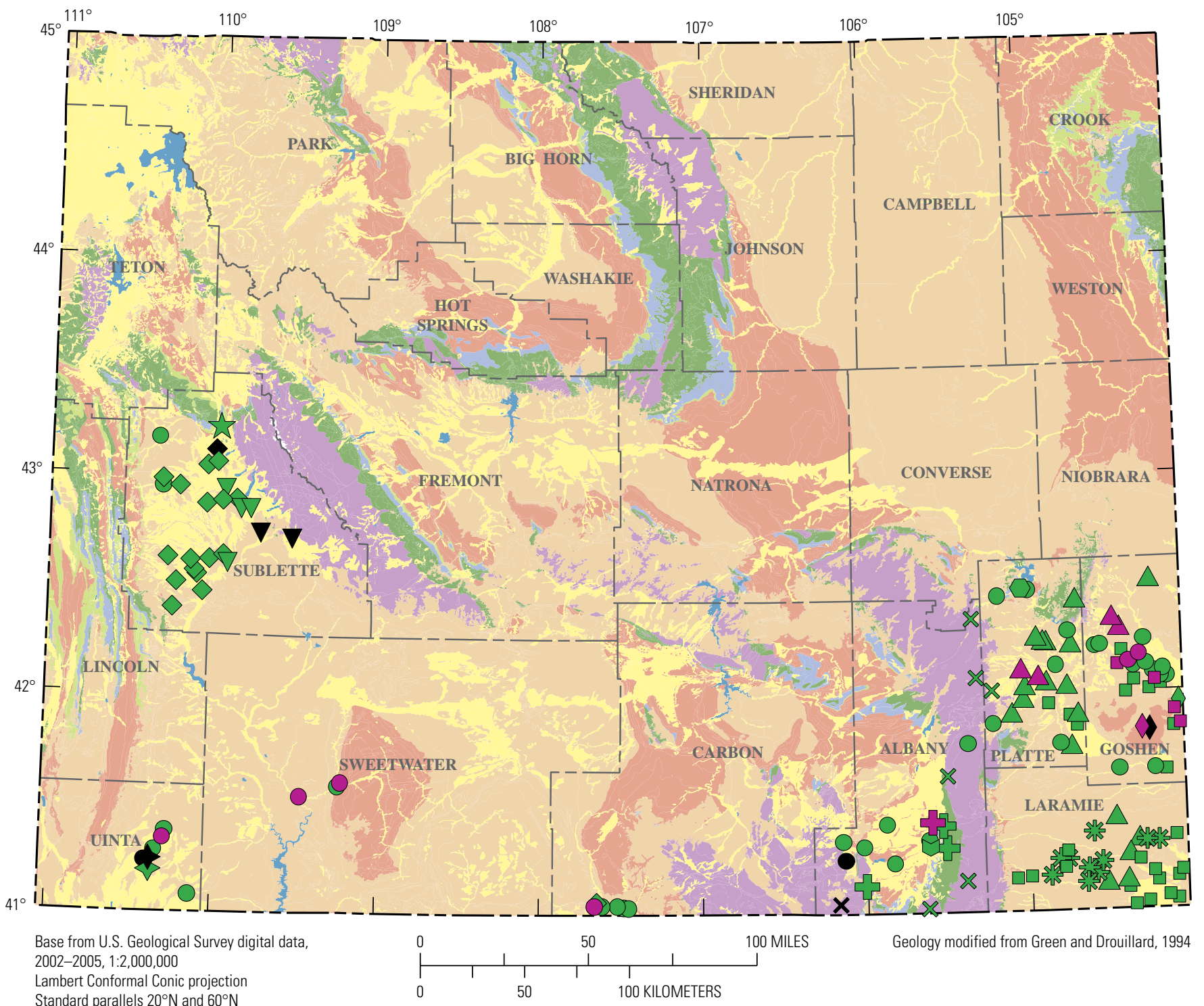

parallels $20^{\circ} \mathrm{N}$ and $60^{\circ} \mathrm{N}$

Central meridian $107^{\prime} 30^{\circ} \mathrm{W}$

North American Datum of 1983

\section{EXPLANATION}

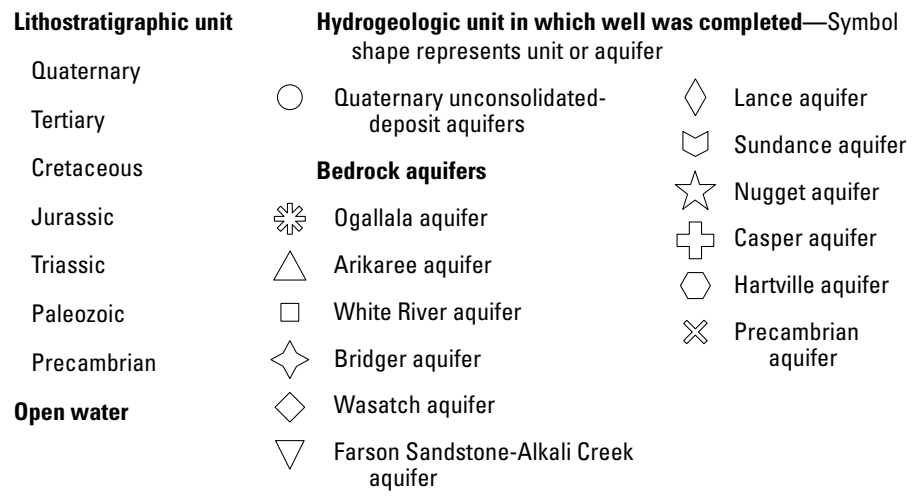

Total uranium, in micrograms per liter-Symbol color represents concentration. Symbols are arranged by geologic age from youngest to oldest (left to right)

- $\quad$ Less than detection limit

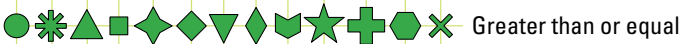
to detection limit and less than 30

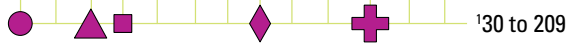

'U.S. Environmental Protection Agency Maximum Contaminant Level (U.S. Environmental Protection Agency, 2012c) and Wyoming Department of Environmental Quality Class Special (A) fish and aquatic life groundwater standard (Wyoming Department of Environmental Quality, 2005).

Figure 28. Concentrations of total uranium in groundwater from wells sampled for the Wyoming Groundwater-Quality Monitoring Network, November 2009 through September 2012. 


\section{Environmental Isotopes}

Environmental isotopes were analyzed as part of the WGWMN to provide some information about the relative age or flow path of groundwaters. Stable isotopes of hydrogen and oxygen were analyzed in all 146 samples, and tritium was analyzed in 18 selected samples.

The composition of stable isotopes of hydrogen and oxygen are reported using delta $(\delta)$ notation, which compares the ratio between heavy and light isotopes of a sample to that of a reference standard. Delta values are expressed as a difference, in parts per thousand or per mil, from values of a reference standard. In this report, stable isotopes of hydrogen $\left(\delta^{2} \mathrm{H}\right.$ or deuterium/protium isotopic ratio) and oxygen $\left[\left(\delta^{18} \mathrm{O}\right)\right.$ or oxygen-18/oxygen-16 $\left({ }^{18} \mathrm{O} /{ }^{16} \mathrm{O}\right.$ isotopic ratio)] are reported in per mil relative to Vienna Standard Mean Ocean Water (Clark and Fritz, 1997). The value for $\delta$ is calculated using the following equation (Clark and Fritz, 1997):

$$
\delta(\text { in per mil })=\left[\left(R_{\mathrm{x}} / R_{\mathrm{s}}\right)-1\right] \times 1,000
$$

where

$$
\begin{aligned}
& R_{\mathrm{x}} \quad \begin{array}{l}
\text { is the ratio of the heavy-to-light isotope of the } \\
\text { sample, and }
\end{array} \\
& R_{\mathrm{s}} \quad \begin{array}{l}
\text { is the ratio of the heavy-to-light isotope of the } \\
\text { applicable reference standard. }
\end{array}
\end{aligned}
$$

The isotopic composition of water changes in response to evaporation of the water and precipitation, as well as in response to climatic differences and differences in altitude. This change in isotopic ratios can be used as a tool for characterizing the water pathway through the hydrologic cycle (Clark and Fritz, 1997). The Global Meteoric Water Line (GMWL) is a global average of the isotopic relation between $\delta^{18} \mathrm{O}$ and $\delta^{2} \mathrm{H}$ in worldwide fresh surface water, whereas a Local Meteoric Water Line (LMWL) of a slightly different slope and intercept is developed for a specific region for the purpose of comparison. For regional or local investigations, it is helpful to compare surface water and groundwater data with a LMWL, if available (Clark and Fritz, 1997), because changes that occur in the hydrologic cycle are useful for determining sources of groundwater recharge and for evaluating surface water and groundwater interaction (Benjamin and others, 2004). Comparing groundwater isotopic signatures with the LMWL can indicate whether samples primarily follow a distribution reflecting variations in the isotopic composition of precipitation or whether secondary processes such as evaporation or mixing have shifted groundwater sample values off of the LMWL (Coplen and others, 1991). Less negative (enriched) values reflect higher temperatures, coastal environments, lower altitude, lower latitude, warmer recharge source water, or warmer precipitation; more negative (depleted) values reflect lower temperatures, continental environments, higher altitude, higher latitude, cooler recharge source water, or cooler precipitation (Clark and Fritz, 1997). The North Platte LMWL was developed for the North Platte, Nebraska, area in the semiarid north-central part of the Great Plains using data collected from 1989 through 1994 (Harvey and Welker, 2000). The Pawnee LMWL was developed for the Pawnee Grasslands of northeastern Colorado in the semiarid north-central part of the Great Plains using data collected from 1994 through 1998 (Harvey, 2005).

Stable isotopes of hydrogen $\left(\delta^{2} \mathrm{H}\right.$ or deuterium/protium isotopic ratio) values for 146 samples ranged from -158 to -84.6 per mil, with a median of -115 per mil (tables 5 and $1-6)$. Stable isotopes of oxygen $\left[\left(\delta^{18} \mathrm{O}\right)\right.$ or oxygen-18/ oxygen-16 $\left({ }^{18} \mathrm{O} /{ }^{16} \mathrm{O}\right.$ isotopic ratio)] values for 146 samples ranged from -20.3 to -8.50 per mil, with a median of -14.9 per mil.

Stable isotopes of hydrogen and oxygen measured in water samples collected from wells completed in hydrogeologic units that are part of the High Plains aquifer system (table 2) are plotted on figure 29, and compared to the GMWL (Craig, 1961) and two LMWLs (North Platte, Nebraska, Harvey and Welker, 2000; Pawnee National Grassland, Colorado, Harvey 2005; locations not shown in report). Paired $\delta^{18} \mathrm{O}$ and $\delta^{2} \mathrm{H}$ values show a linear trend that generally plots slightly below the GMWL and LMWLs, indicating that recharge to the wells was derived from precipitation and that the water has undergone some fractionation, possibly because of evaporation (Clark and Fritz, 1997). Stable isotopes of hydrogen and oxygen measured in water samples collected from wells completed in hydrogeologic units other than the High Plains aquifer system are plotted on figure 30, and are shown in relation only to the GMWL (Clark and Fritz, 1997) because no LMWLs have been developed in nearby areas with similar climatic conditions. Similarly, these results plot slightly below the GMWL and indicate that recharge to the wells was derived from precipitation and that the water has undergone some fractionation, possibly because of evaporation (Clark and Fritz, 1997).

Tritium (or hydrogen-3) occurs naturally and from human activities, and can be used to qualitatively estimate the apparent age of groundwater. Tritium can incorporate into the water molecule and therefore follow the pathway of water through its flow and mixing processes. This makes tritium a valuable tracer in hydrologic studies (Michel, 1989; Clark and Fritz, 1997). Atmospheric testing of thermonuclear bombs beginning in the early 1950s raised levels of tritium in the atmosphere by several orders of magnitude (Michel, 1989). Before atmospheric testing of thermonuclear devices, the natural level of tritium in precipitation probably did not exceed about $26 \mathrm{pCi} / \mathrm{L}$ (Plummer and others, 1993). If precipitation with tritium measured at an activity of $26 \mathrm{pCi} / \mathrm{L}$ or less recharged groundwater before 1952, those waters would have tritium present at an activity about $1 \mathrm{pCi} / \mathrm{L}$ in 2009-12 (years wells were sampled for this study) because of radioactive decay. Therefore, measurement of tritium at an activity level greater than about $1 \mathrm{pCi} / \mathrm{L}$ would indicate that at least some fraction of the sampled groundwater was recharged after the early 1950s. 


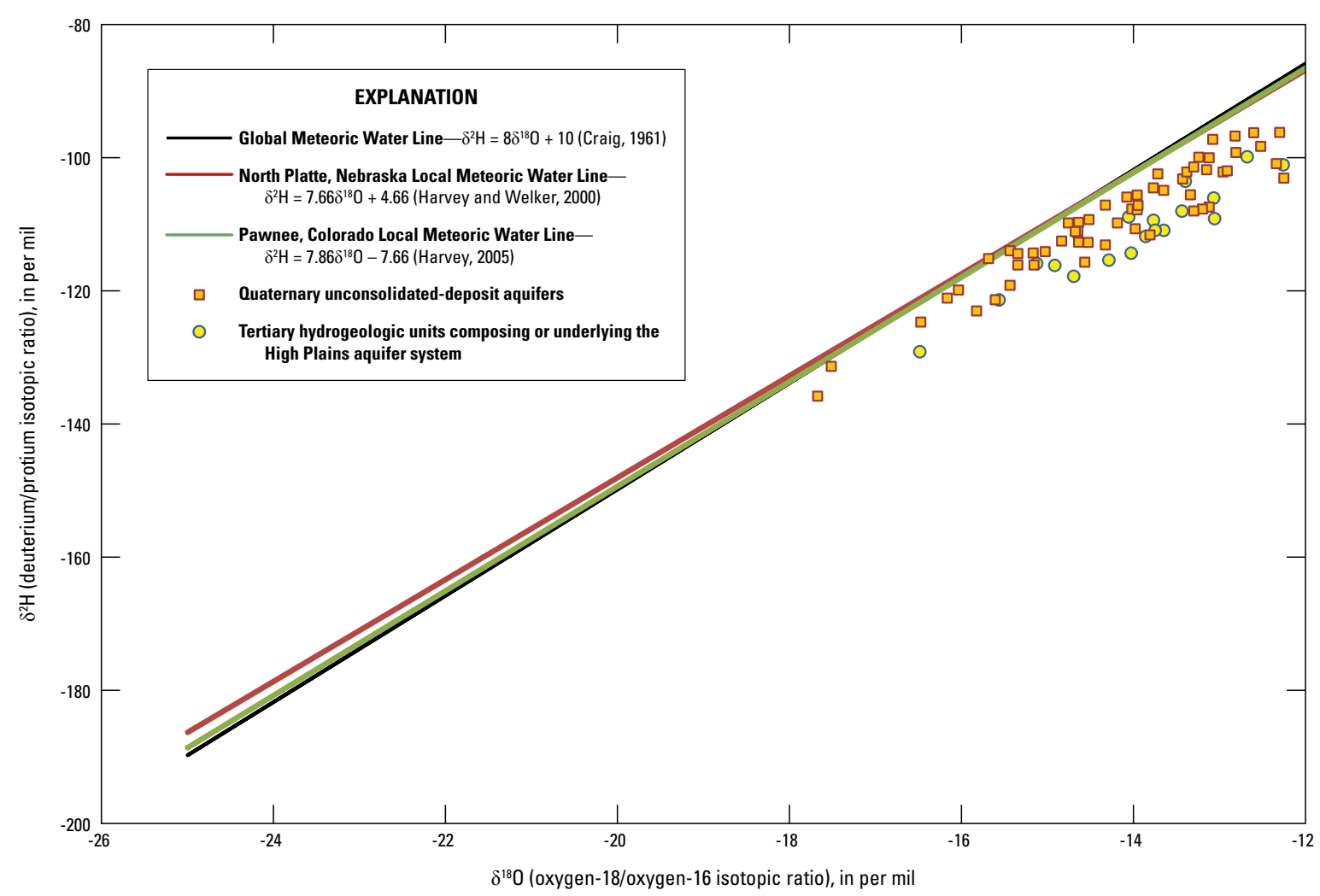

Figure 29. Relation between oxygen and hydrogen isotopic ratios in groundwater from wells completed in the High Plains aquifer system sampled for the Wyoming Groundwater-Quality Monitoring Network, November 2009 through September 2012.

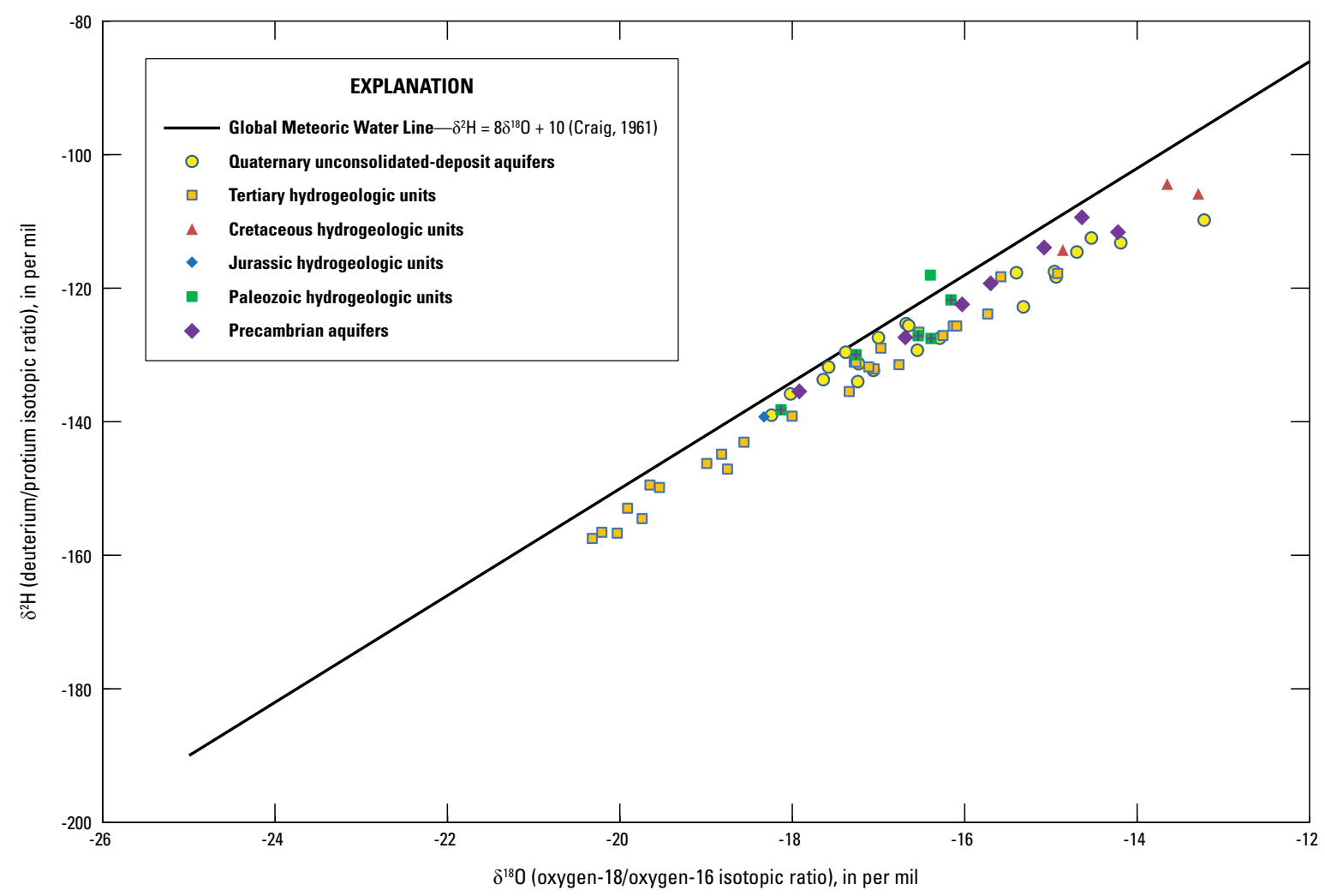

Figure 30. Relation between oxygen and hydrogen isotopic ratios in groundwater from wells not completed in the High Plains aquifer system sampled for the Wyoming Groundwater-Quality Monitoring Network, November 2009 through September 2012. 
Two tritium samples were collected from each priority area at wells in locations likely to contain younger waters. Tritium activities for 18 samples ranged from R0.08 \pm 0.38 to $39.2 \pm 1.3 \mathrm{pCi} / \mathrm{L}$ (table $1-6$ ), with a median activity of $22.8 \mathrm{pCi} / \mathrm{L}$. Tritium was measured at activities greater than $1 \mathrm{pCi} / \mathrm{L}$ in all seven samples collected from Quaternary unconsolidated-deposit aquifers and in the one sample collected from the Nugget aquifer (table 1-6). In the Wasatch zone of the Wasatch-Fort Union aquifer, tritium was detected in all eight groundwater samples, and activities greater than $1 \mathrm{pCi} / \mathrm{L}$ were measured in five samples. Tritium was measured at activities greater than $1 \mathrm{pCi} / \mathrm{L}$ in the two samples collected from the Farson Sandstone-Alkali Creek aquifer.

\section{Organic Compounds}

Samples for organic compounds were collected and analyzed for the WGQMN. Organic compounds analyzed for included VOCs, GRO, DRO, dissolved hydrocarbon gases, and wastewater compounds.

\section{Volatile Organic Compounds}

Volatile organic compounds (VOCs) generally are manmade chemicals present in many commonly used products such as plastics, paints, refrigerants, petroleum products, lubricants, solvents, fumigants, pesticides, personal hygiene products, and disinfection byproducts (Zogorski and others, 2006). Many VOCs are highly soluble, mobile, and persistent in groundwater (Bartos and others, 2004). A statistical summary of VOCs from groundwater-quality samples collected for the WGQMN is reported in table 5. Results from individual analyses are presented in table 1-7. Few VOCs were detected and no measured concentrations exceeded any national or State of Wyoming standards. Concentrations of VOCs in groundwater sampled collected for the WGQMN are compared to median concentrations measured in groundwater samples collected during 1985-2001 for the USGS NAWQA Program.

Benzene, toluene, ethylbenzene, and xylene compounds are VOCs that typically are present in petroleum products such as diesel fuel and gasoline, but also occur in some natural gas reservoirs. Benzene was detected in 1 of 145 samples collected for the WGQMN at an estimated concentration of $0.018 \mu \mathrm{g} / \mathrm{L}$. The median benzene concentration was $<0.20 \mu \mathrm{g} / \mathrm{L}$ in groundwater samples collected from aquifers across the United States during 1985-2001 for the USGS NAWQA Program (Zogorski and others, 2006). Toluene concentrations for 146 samples ranged from $<0.02$ to $9.8 \mu \mathrm{g} / \mathrm{L}$. The median toluene concentration was $<0.20 \mu \mathrm{g} / \mathrm{L}$ in groundwater samples collected from aquifers across the United States during 19852001 for the USGS NAWQA Program (Zogorski and others, 2006). Ethylbenzene was detected in 1 of 146 sample collected for the WGQMN at an estimated concentration of $0.32 \mu \mathrm{g} / \mathrm{L}$.
The median ethylbenzene concentration was $<0.20 \mu \mathrm{g} / \mathrm{L}$ in groundwater samples collected from aquifers across the United States during 1985-2001 for the USGS NAWQA Program (Zogorski and others, 2006). The combined isomers for meta- and para-xylene were detected in 1 of 146 samples collected for the WGQMN at an estimated concentration of $0.02 \mu \mathrm{g} / \mathrm{L}$. The median meta- and para-xylene concentration was $<0.060 \mu \mathrm{g} / \mathrm{L}$ in groundwater samples collected from aquifers across the United States during 1985-2001 for the USGS NAWQA Program (Zogorski and others, 2006).

\section{Gasoline Range and Diesel Range Organics}

Gasoline range organics (GRO) are petroleum products in the C6 to C10 (6 to 10 carbon atoms) range, including gasoline and naphthalene. Gasoline range organics were detected in nine of 116 samples (fig. 31; tables 5 and 1-7). The GRO concentrations ranged from $<4.0$ to $27 \mu \mathrm{g} / \mathrm{L}$ with a median (calculated using the log-probability regression procedure) of $4.47 \mu \mathrm{g} / \mathrm{L}$.

Diesel range organics (DRO) are petroleum products in the C10 to C28 (10 to 28 carbon atoms) range, including diesel fuel, jet fuel, mineral spirits, and kerosene. Diesel range organics were detected in 45 of 116 samples (fig. 32; tables 5 and 1-7). The DRO concentrations ranged from $<0.020$ to $0.140 \mathrm{mg} / \mathrm{L}$ with a median (calculated using the logprobability regression procedure) of $0.016 \mathrm{mg} / \mathrm{L}$.

\section{Dissolved Hydrocarbon Gases}

Dissolved hydrocarbon gases (methane, ethene, and ethane) are frequently used to detect biodegradation processes in contaminated aquifers (Kampbell and Vandegrift, 1998). Methane may be formed by the thermal alteration of organic material (thermogenic) or by microbial degradation of organic matter (biogenic) (Whiticar, 1999). Thermogenic methane generally is produced at greater depths and its presence in water wells can result from gas migration from other formations or from oil and gas extraction activities, whereas biogenic methane generally forms at shallower depths and can occur naturally in anoxic conditions (Thomas and McMahon, 2013). No analysis was completed to determine the origin (thermogenic or biogenic) of methane detected in samples from the WGQMN. Methane concentrations for 116 samples ranged from $<0.22$ to $220 \mu \mathrm{g} / \mathrm{L}$ (fig. 33; tables 5 and 1-7). The median methane concentration (calculated using the logprobability regression procedure) was $0.018 \mu \mathrm{g} / \mathrm{L}$. Methane was detected in 26 of 116 samples, and the maximum methane concentration of $220 \mu \mathrm{g} / \mathrm{L}$ was measured in a sample collected from a 100-ft deep well completed in the Lance aquifer with a DO value indicative of anoxic conditions $(0.07 \mathrm{mg} / \mathrm{L})$. Ethene was detected in a single sample at an estimated concentration of $1.60 \mu \mathrm{g} / \mathrm{L}$. Ethane was detected in a different sample at an estimated concentration of $1.70 \mu \mathrm{g} / \mathrm{L}$. 


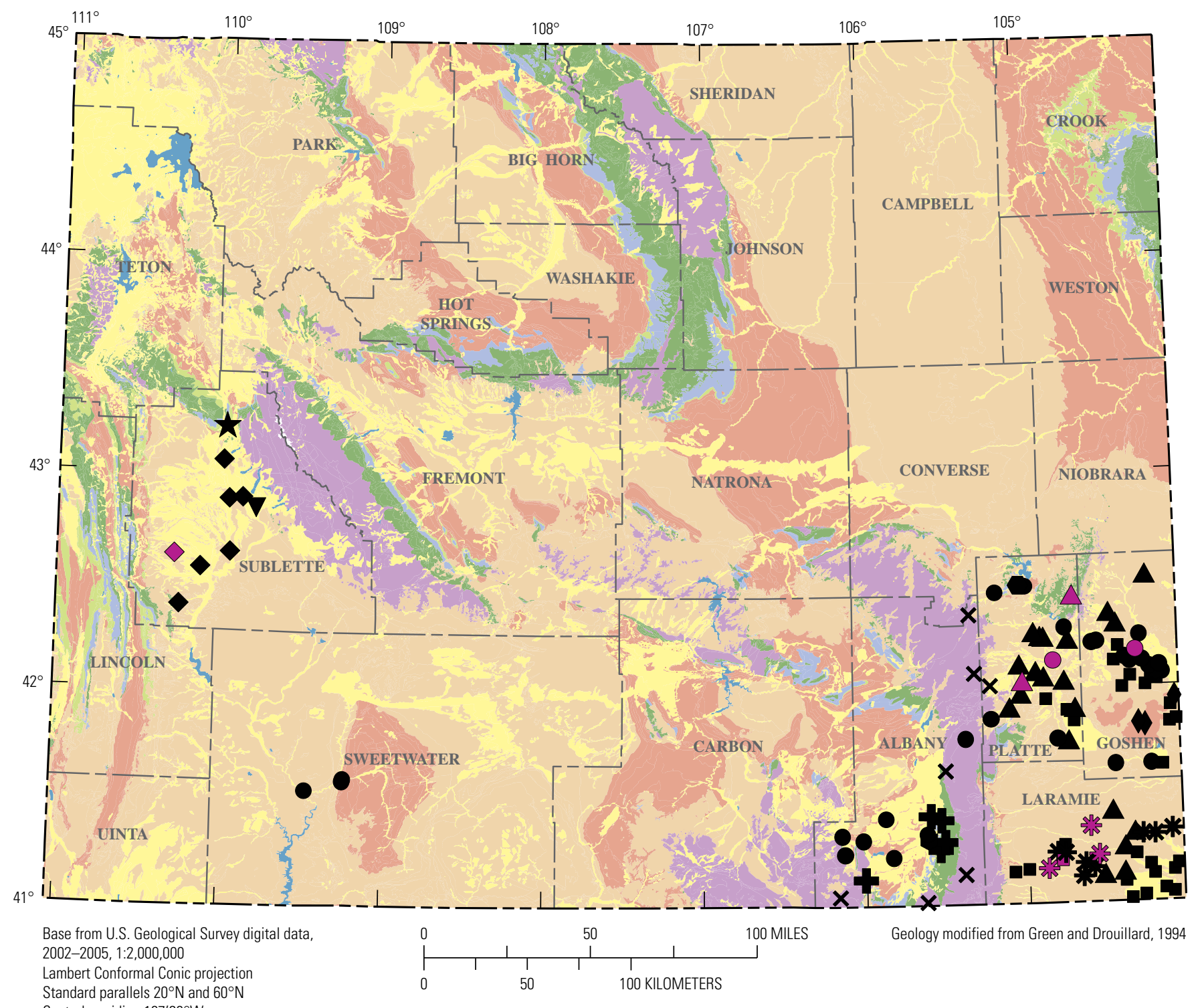

Central meridian $107^{\prime} 30^{\circ} \mathrm{W}$

North American Datum of 1983

\section{EXPLANATION}

Lithostratigraphic unit

Hydrogeologic unit in which well was completed—Symbol shape represents unit or aquifer

Quaternary

Tertiary

Cretaceous

Quaternary unconsolidated-

$\checkmark$ Lance aquifer deposit aquifers

$\checkmark$ Sundance aquifer

Bedrock aquifers

Jurassic

Ogallala aquifer

Nugget aquifer

گ Casper aquifer

Triassic

$\triangle$ Arikaree aquifer

Paleozoic

White River aquifer

Precambrian

$>$ Bridger aquifer

$\checkmark$ Hartville aquifer

$\aleph$ Precambrian

Open water

$\diamond$ Wasatch aquifer

$\nabla$ Farson Sandstone-Alkali Creek aquifer

Gasoline range organics-Symbol color represents concentrations less than or greater than or equal to detection limit. Symbols are arranged by geologic age from youngest to oldest (left to right)

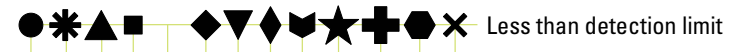

$O v^{n} \Delta \square$

Greater than or equal to detection limit

Figure 31. Concentrations of gasoline range organics in groundwater from wells sampled for the Wyoming Groundwater-Quality Monitoring Network, November 2009 through September 2012. 


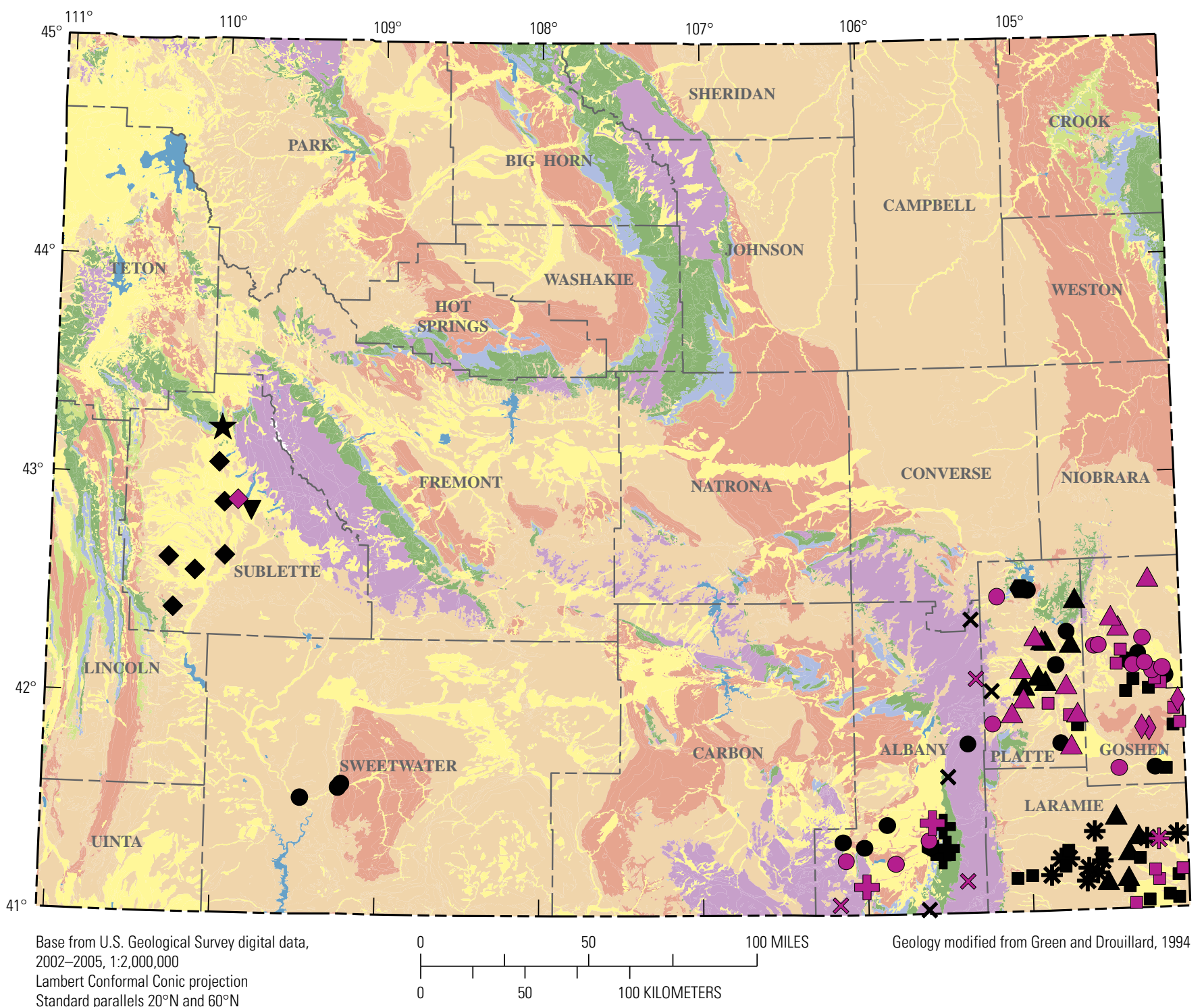

Standard parallels $20^{\circ} \mathrm{N}$ and $60^{\circ} \mathrm{N}$

Central meridian $107^{\prime} 30^{\circ} \mathrm{W}$

North American Datum of 1983

\section{EXPLANATION}

Lithostratigraphic unit

Quaternary

Tertiary

Cretaceous

Jurassic

Triassic

Paleozoic

Precambrian

Open water
Hydrogeologic unit in which well was completed-Symbol shape represents unit or aquifer

Quaternary unconsolidated
deposit aquifers

Bedrock aquifers

Sh Ogallala aquifer

$\triangle$ Arikaree aquifer

$\square \quad$ White River aquifer

$\curvearrowright$ Bridger aquifer

$\diamond$ Wasatch aquifer

$\nabla$ Farson Sandstone-Alkali Creek
Diesel range organics - Symbol color represents concentrations less than or greater than or equal to detection limit. Symbols are arranged by geologic age from youngest to oldest (left to right)

米A口 P Y Less than detection limit

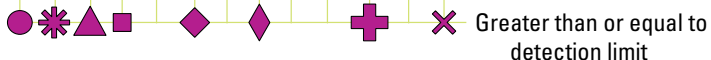

Figure 32. Concentrations of diesel range organics in groundwater from wells sampled for the Wyoming Groundwater-Quality Monitoring Network, November 2009 through September 2012. 


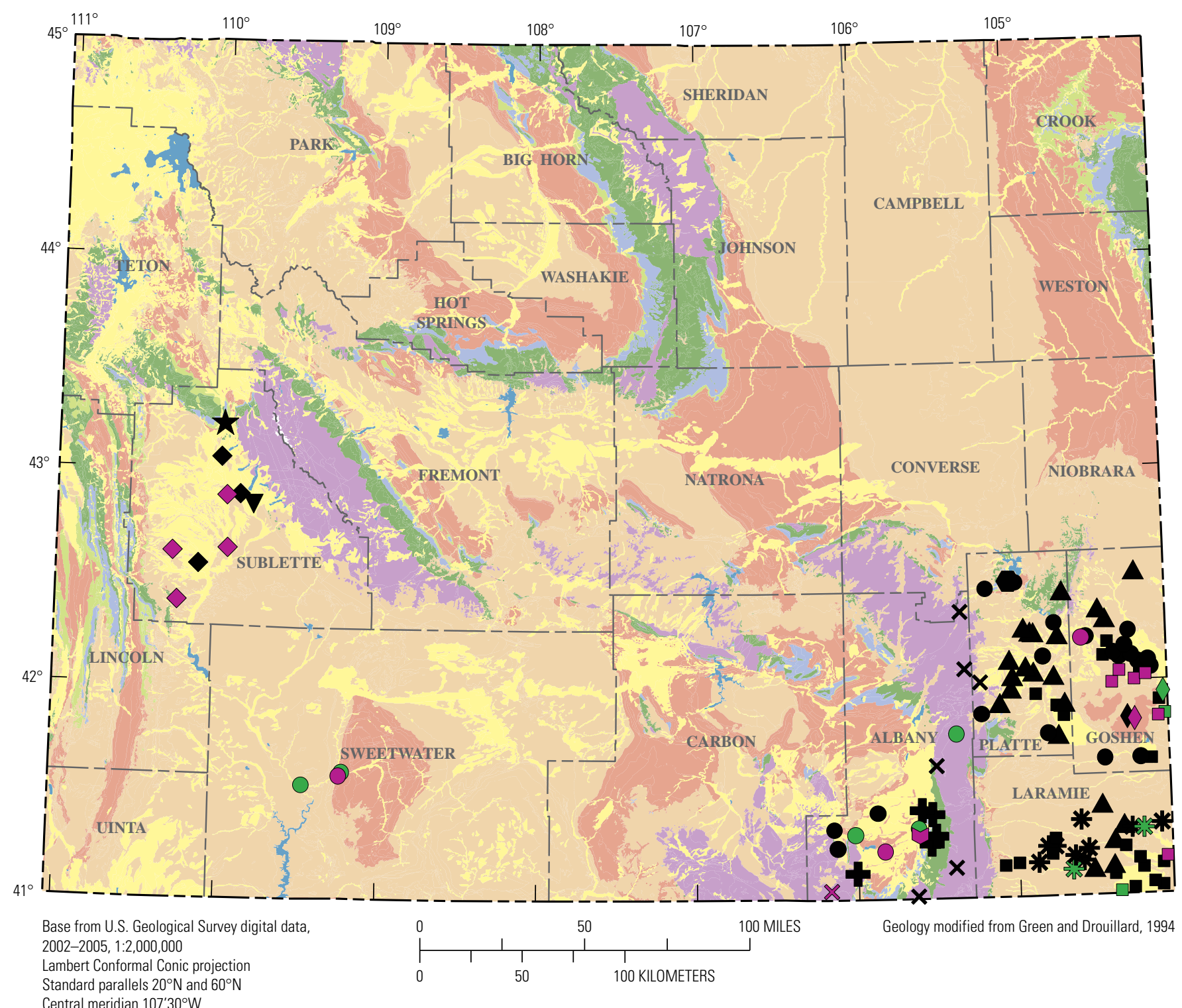

Standard parallels $20^{\circ} \mathrm{N}$ and $60^{\circ} \mathrm{N}$

Central meridian $107^{\prime} 30^{\circ} \mathrm{W}$

North American Datum of 1983

EXPLANATION

Lithostratigraphic unit

Quaternary

Tertiary

Cretaceous

Jurassic

Triassic

Paleozoic

Precambrian

Open water
Hydrogeologic unit in which well was completed-Symbol shape represents unit or aquifer

Quaternary unconsolidateddeposit aquifers

Bedrock aquifers

ins Ogallala aquifer

$\triangle$ Arikaree aquifer

$\square \quad$ White River aquifer

$\diamond$ Bridger aquifer

$\diamond$ Wasatch aquifer

$\nabla$ Farson Sandstone-Alkali Creek aquifer

$\checkmark$ Sundance aquife

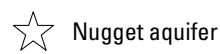

$\square$ Hartville aquifer

$\aleph \begin{gathered}\text { Precambrian } \\ \text { aquifer }\end{gathered}$
Methane, in micrograms per liter-Symbol color represents concentration. Symbols are arranged by geologic age from youngest to oldest (left to right)

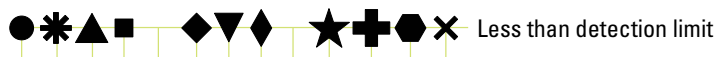

گCasper aquifer

\section{O紫 $\square$} Greater than or equal to detection limit and less than 1

\ 1 to 220

Figure 33. Concentrations of methane in groundwater from wells sampled for the Wyoming Groundwater-Quality Monitoring Network, November 2009 through September 2012. 


\section{Wastewater Compounds}

Analytical methods using representative compounds from various chemical classes are used to monitor contaminants in wastewater discharges. Wastewater compounds are indicative of wastewater or of waters that possess endocrine-disrupting potential or toxicity. These compounds include the alkylphenol ethoxylate nonionic surfactants and their degradates, food additives, fragrances, antioxidants, flame retardants, plasticizers, industrial solvents, disinfectants, fecal sterols, polycyclicaromatic hydrocarbons, and high-use domestic pesticides (Zaugg and others, 2007).

A statistical summary of selected wastewater compounds detected in water-quality samples collected for the WGQMN is reported in table 5. Results of all wastewater compounds from individual analyses are presented in table $1-8$. Few wastewater compounds were detected, and no measured concentrations exceeded any national or State of Wyoming standards; however, standards have not been determined for many of these compounds. The compound $N, N$-diethylmeta-toluamide (DEET) is a common active ingredient in insect repellents (U.S. Environmental Protection Agency, 2012b). The DEET concentrations for 43 samples ranged from $<0.06$ to an estimated value of $0.12 \mu \mathrm{g} / \mathrm{L}$ with a median (calculated using the log-probability regression procedure) of $0.018 \mu \mathrm{g} / \mathrm{L}$. Benzophenone is used in sunscreen (U.S. Environmental Protection Agency, 2006). Benzophenone concentrations for 43 samples ranged from $<0.08$ to an estimated concentration of $0.03 \mu \mathrm{g} / \mathrm{L}$ with a median (calculated using the log-probability regression procedure) of $0.017 \mu \mathrm{g} / \mathrm{L}$. Phenanthrene is used to make dyes, explosives, and drugs (U.S. Environmental Protection Agency, 2010). Phenanthrene concentrations for 43 samples ranged from $<0.016$ to an estimated concentration of $0.030 \mu \mathrm{g} / \mathrm{L}$ with a median (calculated using log-probability regression procedure) of $0.008 \mu \mathrm{g} / \mathrm{L}$. These compounds may have been detected during sampling because of consumer products used by field personnel.

\section{Coliform Bacteria}

Groundwater samples were tested for the presence of coliform bacteria, which are naturally present in the environment and indicate the presence of other, potentially harmful, bacteria. Escherichia coli (E. coli) only occur in the fecal waste of warm-blooded animals, including humans. Microbes in this waste can cause health problems, including diarrhea, cramps, nausea, and headaches, and are of special concern for infants, young children, and people with compromised immune systems (U.S. Environmental Protection Agency, 2013c). A statistical summary of coliform bacteria detected in water-quality samples collected for the WGQMN is reported in table 5. Results from individual analyses are presented in table 1-9. Results are reported as estimated (E) and qualified (k) when counts were outside the ideal range determined for methods.

Total coliform bacteria ranged from $<1$ to an estimated 111 colonies per $100 \mathrm{~mL}$ (colonies/100 mL), with a median (calculated using the log-probability regression procedure) of $<1$ colonies/100 mL. The EPA MCLG for total coliforms (zero colonies $/ 100 \mathrm{~mL}$ ) was exceeded in 60 of 141 samples (fig. 34). Concentrations of $E$. coli bacteria ranged from $<1$ to an estimated 3 colonies $/ 100 \mathrm{~mL}$. A median E. coli value could not be calculated for these samples using the log-probability regression procedure because too many values were censored. The EPA MCLG for E. coli (zero colonies/100 mL) was exceeded in 2 of 141 samples (fig. 35). Proper well construction, including surface seals and grouting, helps reduce the potential for transport of bacteria along the casing from the land surface to the groundwater. Observations made at the time of sampling indicated that the casings of most of the wells sampled appeared to be in good condition at the surface; however, no downhole observations were made. Most of the wells also were located away from potential bacteria sources such as manure piles and septic systems. 


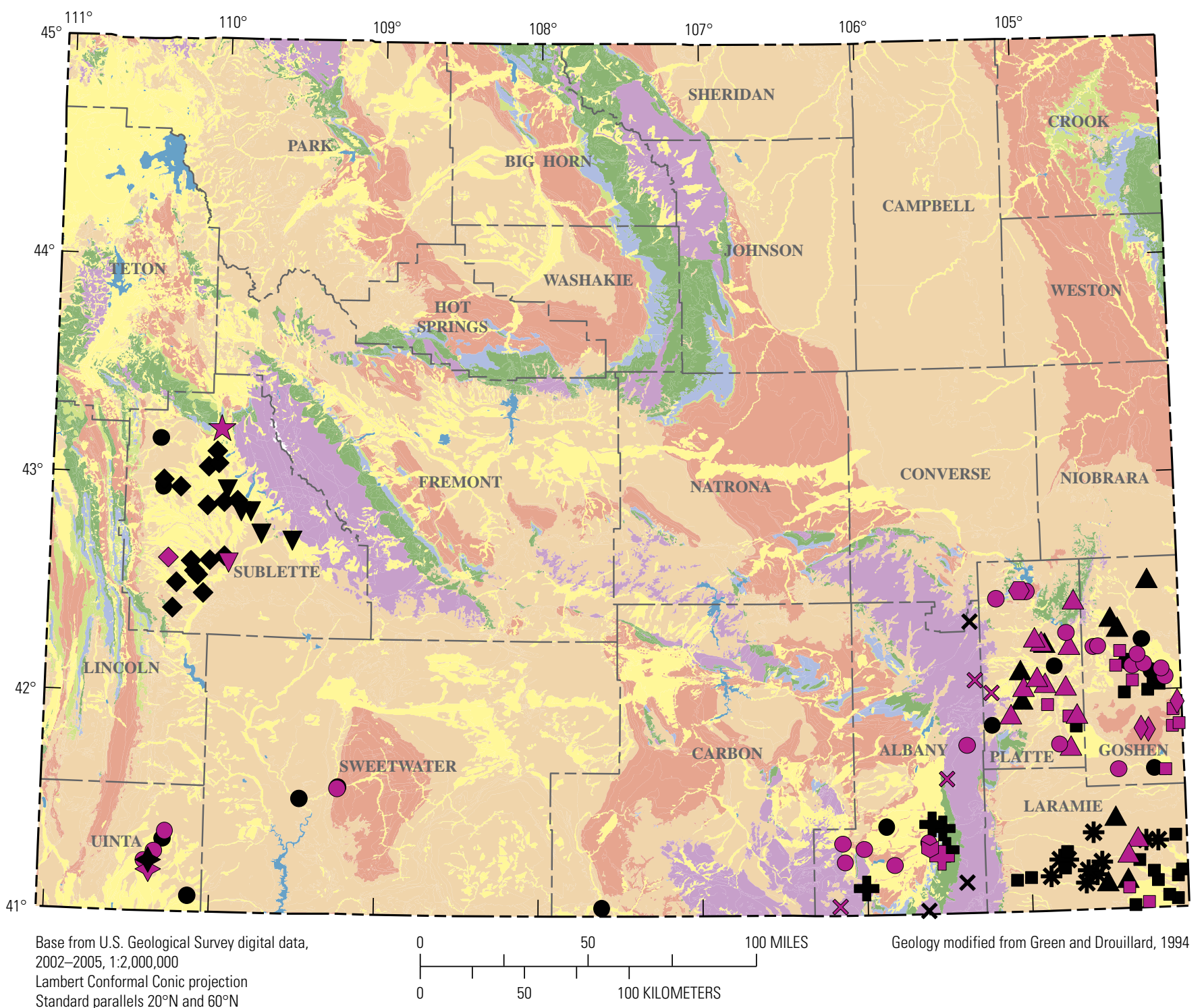

Standard parallels $20^{\circ} \mathrm{N}$ and $60^{\circ} \mathrm{N}$

Central meridian $107^{\prime} 30^{\circ} \mathrm{W}$

North American Datum of 1983

\section{EXPLANATION}

Lithostratigraphic unit

Quaternary

Tertiary

Cretaceous

Jurassic

Triassic

Paleozoic

Precambrian

Open water
Hydrogeologic unit in which well was completed-Symbol shape represents unit or aquifer

Quaternary unconsolidateddeposit aquifers

Bedrock aquifers

Ogallala aquifer

$\triangle$ Arikaree aquifer

$\square \quad$ White River aquifer

$\lesssim$ Bridger aquifer

$\diamond$ Wasatch aquifer

$\nabla$ Farson Sandstone-Alkali Creek aquife
Total coliforms, in colonies per $\mathbf{1 0 0}$ milliliters-Symbol color represents colony count. Symbols are arranged by geologic age from youngest to oldest (left to right)

\section{$\boldsymbol{O} * \boldsymbol{\Delta} \boldsymbol{\nabla} \boldsymbol{\nabla} \quad \boldsymbol{\nabla}$ Less than 1}

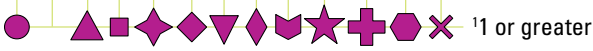

'U.S. Environmental Protection Agency Maximum Contaminant Level Goal (U.S. Environmental Protection Agency, 2012c).

Figure 34. Presence of total coliforms in groundwater from wells sampled for the Wyoming Groundwater-Quality Monitoring Network, November 2009 through September 2012. 


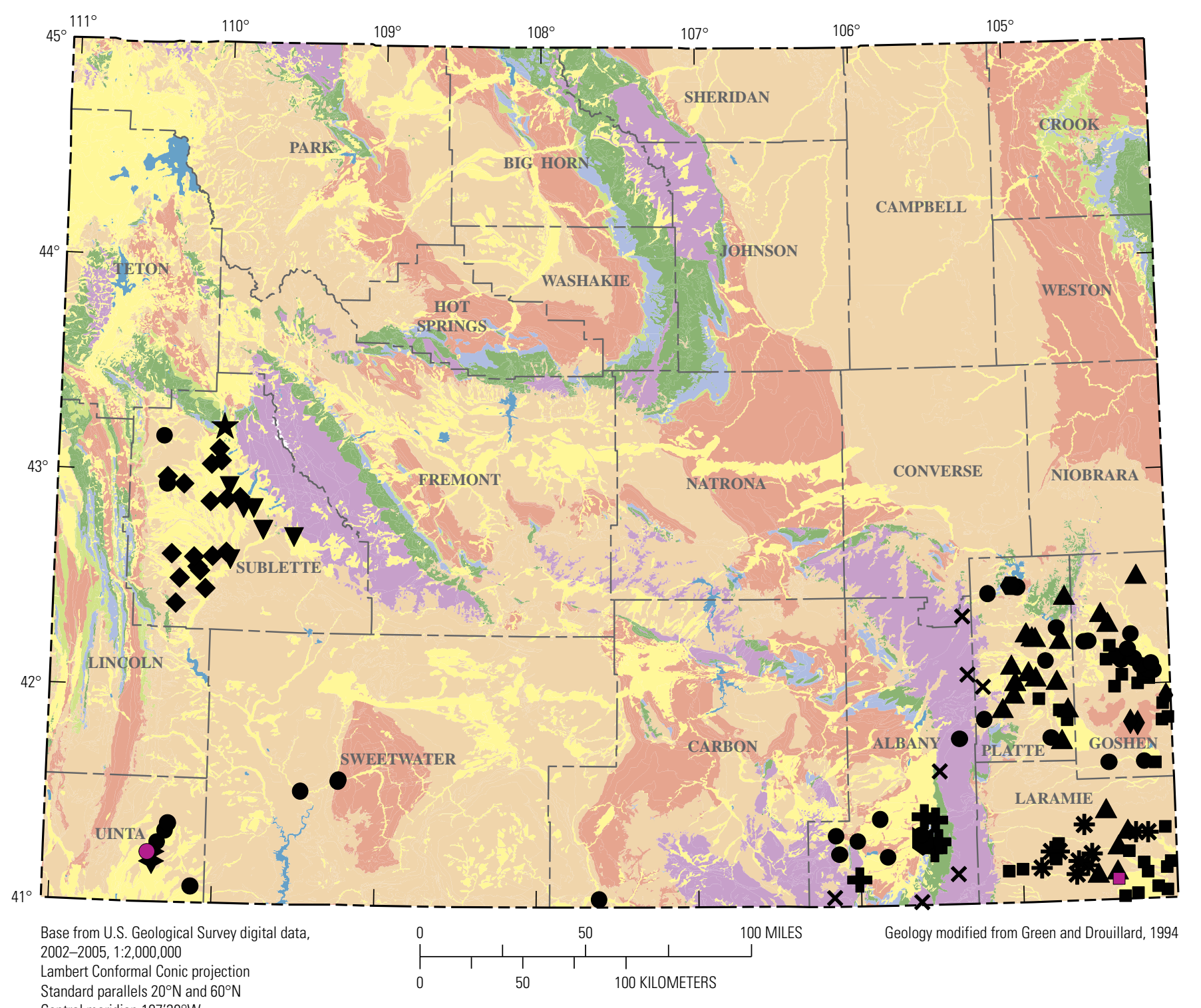

Standard parallels $20^{\circ} \mathrm{N}$ and $60^{\circ} \mathrm{N}$

Central meridian $107^{\prime} 30^{\circ} \mathrm{W}$

North American Datum of 1983

\section{EXPLANATION}

Lithostratigraphic unit

\section{Quaternary}

Tertiary

Cretaceous

Jurassic

Triassic

Paleozoic

Precambrian

Open water
Hydrogeologic unit in which well was completed-Symbol shape represents unit or aquifer

Quaternary unconsolidateddeposit aquifers

Bedrock aquifers

Ogallala aquifer

$\triangle$ Arikaree aquifer

$\square \quad$ White River aquifer

$\diamond$ Bridger aquifer

$\triangle$ Wasatch aquifer

$\nabla$ Farson Sandstone-Alkali Creek aquifer
Escherichia coli, in colonies per $\mathbf{1 0 0}$ milliliters-Symbol color represents colony count. Symbols are arranged by geologic age from youngest to oldest (left to right)

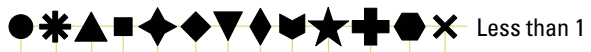

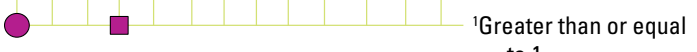

to 1

'U.S. Environmental Protection Agency Maximum Contaminant Level Goal (U.S. Environmental Protection Agency, 2012c).

Figure 35. Presence of Escherichia coli in groundwater from wells sampled for the Wyoming Groundwater-Quality Monitoring Network, November 2009 through September 2012. 


\section{Summary}

Groundwater samples were collected and analyzed from 146 wells during November 2009 through September 2012 for the Wyoming Groundwater-Quality Monitoring Network. Shallow wells (defined as less than or equal to 500 feet deep) selected for sampling were completed in Quaternary unconsolidated-deposit aquifers and shallow bedrock aquifers.

Most groundwater samples were analyzed for physical characteristics, major ions, trace elements, nutrients and dissolved organic carbon, uranium, stable isotopes of hydrogen and oxygen, volatile organic compounds, and coliform bacteria. Selected samples also were analyzed for radionuclides (gross alpha radioactivity, gross beta radioactivity, radon, and tritium), gasoline range organics, diesel range organics, dissolved hydrocarbon gases (methane, ethene, and ethane), and wastewater compounds.

Water-quality results were compared to national drinking water standards established or proposed by the U.S. Environmental Protection Agency (EPA). Constituents and physical characteristics that exceeded EPA Maximum Contaminant Levels were arsenic (7 of 146 samples), selenium (3 of 146 samples), nitrite (1 of 140 samples), nitrate (4 of 140 samples), gross alpha activity (2 of 12 samples), and uranium (16 of 146 samples). Total coliforms (60 of 141 samples) and Escherichia coli (2 of 141 samples) exceeded EPA Maximum Contaminant Level Goals. Measurements of $\mathrm{pH}$ (18 of 146 samples) and turbidity (12 of 146 samples), and concentrations of chloride (3 of 140 samples), sulfate (16 of 140 samples), fluoride (5 of 140 samples), dissolved solids (49 of 146 samples), aluminum (14 of 146 samples), iron (13 of 136 samples), and manganese (14 of 136 samples) exceeded EPA Secondary Maximum Contaminant Levels. Radon (12 of 14 samples) exceeded the alternative Maximum Contaminant Level proposed by the EPA. Molybdenum (1 of 146 samples) and boron (1 of 146 samples) exceeded the EPA Health Advisory Level.

Water-quality results also were compared to Wyoming Department of Environmental Quality (WDEQ) groundwater standards. Constituents and physical characteristics that exceeded WDEQ Class I domestic groundwater standards were $\mathrm{pH}$ (18 of 146 samples), chloride (3 of 140 samples), sulfate (16 of 140 samples), dissolved solids (49 of 146 samples), iron (13 of 136 samples), manganese (14 of 136 samples), boron (5 of 146 samples), selenium (3 of 146 samples), nitrite ( 1 of 140 samples), and nitrate (4 of 140 samples). Measurements of $\mathrm{pH}$ (4 of 146 samples) and concentrations of chloride (5 of 140 samples), sulfate (19 of 140 samples), dissolved solids (6 of 146 samples), aluminum (1 of 146 samples), iron (1 of 146 samples), manganese (7 of 136 samples), boron (5 of 146 samples), and selenium (5 of 146 samples) exceeded WDEQ Class II agriculture groundwater standards. Measurements of $\mathrm{pH}$ (18 of 146 samples) and concentrations of sulfate (3 of 140 samples), dissolved solids (4 of 146 samples), aluminum (1 of 146 samples), boron (1 of 146 samples), and selenium (3 of 146 samples) exceeded WDEQ Class III livestock groundwater standards. Measurements of $\mathrm{pH}$ (10 of 146 samples), dissolved solids (49 of 146 samples), aluminum (14 of 146 samples), iron (10 of 146 samples), manganese (3 of 136 samples), and selenium (3 of 146 samples) exceeded WDEQ Class special (A) fish and aquatic life groundwater standards. Dissolved solids (2 of 146 samples) exceeded WDEQ Class IV industry groundwater standard.

The stable isotopic composition of water was used to identify potential sources of recharge to wells. Stable isotopes of hydrogen and oxygen measured in water samples collected from wells completed in the High Plains aquifer system were plotted in relation to the Global Meteoric Water Line and two Local Meteoric Water Lines developed in nearby areas with similar climatic conditions. Stable isotopes of hydrogen and oxygen measured in water samples collected from wells completed in hydrogeologic units other than the High Plains aquifer system were shown in relation only to the Global Meteoric Water Line because no Local Meteoric Water Lines have been developed in nearby areas with similar climatic conditions. Recharge to all of the wells was derived from precipitation and the water has undergone some fractionation, possibly because of evaporation.

Volatile organic compounds, gasoline range organics, diesel range organics, and dissolved hydrocarbon gas samples were collected and analyzed. Few volatile organic compounds were detected and no measured concentrations exceeded national or State of Wyoming standards. Gasoline range organics (9 of 116 samples), diesel range organics (45 of 116 samples), and methane (26 of 116 samples) were detected most frequently.

Few wastewater compounds were detected and no measured concentrations exceeded national or State of Wyoming standards. Compounds detected most frequently were $N, N$-diethyl-meta-toluamide (17 of 43 samples), benzophenone (13 of 43 samples), and phenanthrene (18 of 43 samples).

Bacteria samples were collected, processed, incubated, and enumerated in the field or the U.S. Geological Survey Wyoming Water Science Center. Total coliforms were detected in 60 of 141 samples. Escherichia coli were detected in 2 of 141 samples.

\section{References Cited}

American Public Health Association, 2005, Standard methods for the examination of water and wastewater (21st ed.): Washington, D.C., American Public Health Association, American Water Works Association, and Water Environment Federation, 1368 p.

American Society for Testing and Materials, 1996, Annual book of ASTM standards, section 11, water and environmental technology: v. 11.02, D5072-92, p. 674-676. 
Ayotte, J.D., Gronberg, J.M., and Apodaca, L.E., 2011, Trace elements and radon in groundwater across the United States, 1992-2003: U.S. Geological Survey Scientific Investigations Report 2011-5059, 115 p. [Also available at http://pubs.usgs. gov/sir/2011/5059.]

Bartos, T.T., and Hallberg, L.L., 2010, Green River Basin groundwater and hydrogeologic units, Chapter 5, in Clarey, K.E., Bartos, T.T., Copeland, David, Hallberg, L.L., Clark, M.L., and Thompson, Melissa, Available groundwater determination technical memorandum, Green River Basin water plan II, Groundwater study level 1 (2007-2009): Laramie, Wyo., prepared by the Wyoming State Geological Survey for the Wyoming Water Development Commission, p. 5-1-5-93.

Bartos, T.T., and Hallberg, L.L., 2011, Generalized potentiometric surface, estimated depth to water, and estimated saturated thickness of the High Plains aquifer system, March-June 2009, Laramie County, Wyoming: U.S. Geological Survey Scientific Investigations Map 3180, 1 sheet, scale 1:125,000. [Also available at http://pubs.usgs. gov/sim/3180/.]

Bartos, T.T., Eddy-Miller, C.A., Norris, J.R., Gamper, M.E., and Hallberg, L.L., 2004, Water-quality characteristics of Quaternary unconsolidated-deposit aquifers and Lower Tertiary aquifers of the Bighorn Basin, Wyoming and Montana, 1999-2001: U.S. Geological Survey Scientific Investigations Report 2004-5252, 164 p. [Also available at http://pubs.usgs.gov/sir/2004/5252/.]

Bedessem, M.E., Casey, B., Frederick, K., and Nibbelink, N., 2003, Phase I-Aquifer prioritization, Final report: Prepared for the Wyoming Department of Environmental Quality by the University of Wyoming Department of Civil and Architectural Engineering, Laramie, Wyo., variously paged.

Benjamin, Lyn, Knobel, L.L., Hall, L.F., Cecil, L.D., and Green, J.R., 2004, Development of a local meteoric water line for southeastern Idaho, western Wyoming, and southcentral Montana: U.S. Geological Survey Scientific Investigations Report 2004-5126, 17 p., accessed May 15, 2014, at http://pubs.usgs.gov/sir/2004/5126/.

Boughton, G.K., 2011, Wyoming groundwater-quality monitoring network: U.S. Geological Survey Fact Sheet 2011-3041, 4 p. [Also available at http://pubs.usgs.gov/ fs/2011/3041/.]

Brenton, R.W., and Arnett, T.L., 1993, Methods of analysis by the U.S. Geological Survey National Water Quality Laboratory-Determination of dissolved organic carbon by UV-promoted persulfate oxidation and infrared spectrometry: U.S. Geological Survey Open-File Report 92-480, 12 p., accessed May 15, 2014, at http://pubs.er.usgs.gov/ publication/ofr92480.
Childress, C.J., Oblinger, Foreman, W.T., Connor, B.F., and Maloney, T.J., 1999, New reporting procedures based on long-term method detection levels and some considerations for interpretations of water-quality data provided by the U.S. Geological Survey National Water Quality Laboratory: U.S. Geological Survey Open-File Report 99-193, 20 p., accessed May 15, 2014, at http://water.usgs.gov/owq/ OFR_99-193/index.html.

Clark, I.D., and Fritz, Peter, 1997, Environmental isotopes in hydrogeology: New York, Lewis Publishers, 328 p.

Connor, B.F., Rose, D.L., Noriega, M.C., Murtagh, L.K., and Abney, S.R., 1998, Methods of analysis by the U.S. Geological Survey National Water Quality LaboratoryDetermination of 86 volatile organic compounds in water by gas chromatography/mass spectrometry, including detections less than reporting limits: U.S. Geological Survey Open-File Report 97-829, 78 p., accessed May 15, 2014, at http://nwql.usgs.gov/Public/pubs/OFR97-829/ OFR97-829.html.

Coplen, T.B., Wildman, J.D., and Chen, J., 1991, Improvements in the gaseous hydrogen-water equilibrium technique for hydrogen isotope ratio analysis: Analytical Chemistry, v. 63, no. 9, p. 910-912. [Also available at http://dx.doi.org/10.1021/ac00009a014.]

Cothern, C.R., and Smith, J.E., eds., 1987, Environmental radon: New York, Plenum Publishing Corp., 378 p.

Craig, Harmon, 1961, Isotopic variations in meteoric waters: Science, v. 133, p. 1702-1703. [Also available at http://dx.doi.org/10.1126/science.133.3465.1702.]

Cunningham, W.L., and Schalk, C.W., comps., 2011, Groundwater technical procedures of the U.S. Geological Survey: U.S. Geological Survey Techniques and Methods, book 1, chap. A1, 151 p., accessed May 15, 2014, at http://pubs.usgs.gov/tm/1a1/.

Dubrovsky, N.M., Burow, K.R., Clark, G.M., Gronberg, J.M., Hamilton, P.A., Hitt, K.J., Mueller, D.K., Munn, M.D., Nolan, B.T., Puckett, L.J., Rupert, M.G., Short, T.M., Spahr, N.E., Sprague, L.A., and Wilbur, W.G., 2010, The quality of the Nation's waters-Nutrients in the Nation's streams and groundwater, 1992-2004: U.S. Geological Survey Circular 1350, 174 p. [Also available at http://pubs.usgs. gov/circ/1350/.]

Dupré, D.H, Scott, J.C., Clark, M.L., Canova, M.G, and Stoker, Y.E., 2013, User's manual for the National Water Information System of the U.S. Geological Survey: WaterQuality System, version 5.0-U.S. Geological Survey OpenFile Report 2013-1054, 730 p. [Also available at http:// pubs.er.usgs.gov/publication/ofr20131054.] 
Eddy-Miller, C.A., and Blain, Liberty, 2011, Groundwater quality of southeastern Wyoming: U.S. Geological Survey Fact Sheet 2011-3106, 4 p. [Also available at http://pubs. usgs.gov/fs/2011/3106/.]

Epstein, S., and Mayeda, T., 1953, Variation in $\mathrm{O}^{18}$ content of water from natural sources: Geochemica et Cosmochimica Acta, v. 4, p. 213-223. [Also available at http://dx.doi. org/10.1016/0016-7037(53)90051-9.]

Faires, L.M., 1993, Methods of analysis by U.S. Geological Survey National Water Quality Laboratory-Determination of metals in water by inductively coupled plasma-mass spectrometry: U.S. Geological Survey Open-File Report 92-634, 28 p., accessed May 15, 2014, at http://pubs. er.usgs.gov/publication/ofr92634.

Fishman, M.J., ed., 1993, Methods of analysis by the U.S. Geological Survey National Water Quality LaboratoryDetermination of inorganic and organic constituents in water and fluvial sediments: U.S. Geological Survey OpenFile Report 93-125, 217 p.

Fishman, M.J., and Friedman, L.C., 1989, Methods for determination of inorganic substances in water and fluvial sediments: U.S. Geological Survey Techniques of WaterResources Investigations, book 5, chap. A1, 545 p., accessed May 15, 2014, at http://pubs.usgs.gov/twri/ twri5-a1/.

Garbarino, J.R., 1999, Methods of analysis by the U.S. Geological Survey National Water Quality LaboratoryDetermination of dissolved arsenic, boron, lithium, selenium, strontium, thallium, and vanadium using inductively coupled plasma-mass spectrometry: U.S. Geological Survey Open-File Report 99-93, 31 p., accessed May 15, 2014, at http://nwql.usgs.gov/Public/pubs/OFR99093/OFR99-093.html.

Glover, K.C., Naftz, D.L., and Martin, L.J., 1998, Geohydrology of Tertiary rocks in the Upper Colorado River Basin in Colorado, Utah, and Wyoming, excluding the San Juan Basin: U.S. Geological Survey Water-Resources Investigations Report 96-4105, 103 p. [Also available at http://pubs.er.usgs.gov/publication/wri964105.]

Green, G.N., and Drouillard, P.H., 1994, The digital map of Wyoming in Arc/Info format: U.S. Geological Survey Open-File Report 94-0425, accessed June 28, 2013, at http://www.wsgs.uwyo.edu/Data/GIS/bedrock-metadata. aspx.

Harvey, F.E., 2005, Stable hydrogen and oxygen isotope composition of precipitation in northeastern Colorado: Journal of the American Water Resources Association, v. 42, no. 2, p. 447-459. [Also available at $h t t p: / / d x . d o i$. org/10.1111/j.1752-1688.2005.tb03748.x.]
Harvey, F.E., and Welker, J.M., 2000, Stable isotopic composition of precipitation in the semi-arid north-central portion of the US Great Plains: Journal of Hydrology, v. 238, p. 90-109.[(Also available at $h t t p: / / d x . d o i$. org/10.1016/S0022-1694(00)00316-4.]

Heath, R.C., 1983, Basic ground-water hydrology: U.S. Geological Survey Water-Supply Paper 2220, 84 p. [Also available at http://pubs.er.usgs.gov/publication/wsp2220.]

Hem, J.D., 1989, Study and interpretation of the chemical characteristics of natural water, (3d ed.) U.S. Geological Survey Water-Supply Paper 2254, 263 p. [Also available at http://pubs.usgs.gov/wsp/wsp2254/.]

Jones, S.R., and Garbarino, J.R., 1999, Methods of analysis by the U.S. Geological Survey National Water Quality Laboratory-Determination of arsenic and selenium in water and sediment by graphite furnace-atomic absorption spectrometry: U.S. Geological Survey Open-File Report 98-639, 39 p. [Also available at http://pubs.er.usgs.gov/ publication/ofr98639.]

Jurgens, B.C., McMahon, P.B., Chapelle, F.H., and Eberts, S.M., 2009, An Excel ${ }^{\circledR}$ workbook for identifying redox processes in ground water: U.S. Geological Survey OpenFile Report 2009-1004, 8 p. [Also available at $h t t p: / / p u b s$. usgs.gov/of/2009/1004/.]

Kampbell, D.H., and Vandegrift, S.A., 1998, Analysis of dissolved methane, ethane, and ethylene in ground water by a standard gas chromatographic technique: Journal of Chromatographic Science, v. 36, p. 253-256. [Also available at http://dx.doi.org/10.1093/chromsci/36.5.253.]

Kenny, J.F., Barber, N.L, Hutson, S.S., Linsey, K.S., Lovelace, J.K., and Maupin, M.A., 2009, Estimated use of water in the United States in 2005: U.S. Geological Survey Circular 1344, 52 p. [Also available at http://pubs.usgs.gov/ circ/1344/.]

Lapham, W.W., Wilde, F.D., and Koterba, M.T., 1995, Groundwater data-collection protocols and procedures for the National Water-Quality Assessment ProgramSelection, installation, and documentation of wells, and collection of related data: U.S. Geological Survey OpenFile Report 95-398, 69 p. [Also available at $h t t p: / / p u b s$. er.usgs.gov/publication/ofr95398.]

Libra, R.D., Collentine, Michael, and Feathers, K.R., 1981, Occurrence and characteristics of ground water in the Denver-Julesburg Basin, Wyoming: Laramie, Wyo., University of Wyoming Water Resources Research Institute, v. VIIA-B, variously paged. 
Love, J.D., Christiansen, A.C., and Ver Ploeg, A.J., comps., 1993, Stratigraphic chart showing the Phanerozoic nomenclature for the state of Wyoming: Geological Survey of Wyoming Map Series 41.

Lundy, D.A., 1978, Hydrology and geochemistry of the Casper aquifer in the vicinity of Laramie, Albany County, Wyoming: Laramie, University of Wyoming unpublished M.S. thesis, $76 \mathrm{p}$.

Martin, L.J., 1996, Geohydrology of Tertiary rocks in the Green River structural basin in Wyoming, Utah, and Colorado: U.S. Geological Survey Water-Resources Investigations Report 92-4164, 43 p. [Also available at http://pubs.er.usgs.gov/publication/wri924164.]

McCurdy, D.E., Garbarino, J.R., and Mullin, A.H., 2008, Interpreting and reporting radiological water-quality data: U.S. Geological Survey Techniques and Methods book 5, chap. B6. 33 p., accessed May 15, 2014, at http://pubs.usgs. $\mathrm{gov} / \mathrm{tm} / 05 \mathrm{~b} 06 /$.

McLain, Betty, 1993, Methods of analysis by the U.S. Geological Survey National Water Quality LaboratoryDetermination of chromium in water by graphite furnace atomic absorption spectrophotometry: U.S. Geological Survey Open-File Report 93-449, 16 p.

Michel, R.L., 1989, Tritium deposition in the continental United States, 1953-83: U.S. Geological Survey WaterResources Investigations Report 89-4072, 51 p. [Also available at http://pubs.er.usgs.gov/publication/wri894072.]

Mueller, D.K., Martin, J.D., and Lopes, T.J., 1997, Qualitycontrol design for surface-water sampling in the National Water-Quality Assessment Program: U.S. Geological Survey Open-File Report 97-223, 17 p. [Also available at http://pubs.usgs.gov/of/1997/223/pdf/ofr97-223.pdf.]

Nolan, B.T., and Hitt, K.J., 2003, Nutrients in shallow ground waters beneath relatively undeveloped areas in the conterminous United States: U.S. Geological Survey WaterResources Investigations Report 02-4289, 17 p. [Also available at $h t t p: / / p u b s . u s g s . g o v / w r i / w r i 024289 /$.

Ostlund, H.G., and Dorsey, H.G., 1975, Rapid electrolytic enrichment of hydrogen gas proportional counting of tritium, High Tatras, Czechoslovakia, October 1975, Proceedings: International Conference on Low Radioactivity Measurement and Applications, 6 p.

Piper, A.M., 1944, A graphic procedure in the geochemical interpretation of water analyses: American Geophysical Union Transactions, v. 25, p. 914-923.

Plummer, L.N., Michel, R.L., Thurman, E.M., and Glynn, P.D., 1993, Environmental tracers for age-dating young ground water, in Alley, W.M., ed., Regional ground-water quality: New York, Van Nostrand Reinhold, p. 181-198.
Rubin, E.S., and Davidson, C.I., 2001, Introduction to engineering and environment: McGraw Hill Higher Education, New York, 720 p.

Thomas, J.C., and McMahon, P.B., 2013, Overview of groundwater quality in the Piceance Basin, western Colorado, 1946-2009: U.S. Geological Survey Scientific Investigations Report 2012-5198, 204 p. [Also available at http://pubs.usgs.gov/sir/2012/5198/.]

Timme, P.J., 1995, National Water Quality Laboratory 1995 Services Catalog: U.S. Geological Survey Open-File Report 95-352, p. 92, accessed May 15, 2014, at http://pubs. er.usgs.gov/publication/ofr 95352.

U.S. Environmental Protection Agency, 1980, Prescribed procedures for measurement of radioactivity in drinking water: U.S. Environmental Protection Agency, Environmental Monitoring and Support Laboratory, Office of Research and Development, EPA 600-4-80-032, August 1980, $133 \mathrm{p}$.

U.S. Environmental Protection Agency, 1989, Data evaluation, chap. 5 of Risk assessment guidance for SuperfundVolume I, Human health evaluation manual (Part A): Washington, D.C., Office of Emergency and Remedial Response, U.S. Environmental Protection Agency Report EPA/540/1-89/002, 30 p., accessed November 18, 2013, at $h t t p: / / w w w . e p a . g o v / o s w e r / r i s k a s s e s s m e n t / r a g s a / p d f / c h 5$. $p d f$.

U.S. Environmental Protection Agency, 1999a, Federal Guidance Report No. 13 - Cancer risk coefficients for environmental exposure to radionuclides: Washington, D.C., EPA 402-R-99-001, 335 p.

U.S. Environmental Protection Agency, 1999b, 40 CFR Parts 141 and 142, National Primary Drinking Water Regulations, radon-222, proposed rule: Washington, D.C., Federal Register, v. 64, no. 211, p. 59245-59378.

U.S. Environmental Protection Agency, 2000, National primary drinking water regulations; radionuclides; final rule: Federal Register, v. 65, no. 65, p. 76708-76753. [Also available at $h t t p: / / w w w . g p o . g o v / f d s y s / p k g / F R-2000-$ 12-07/pdf/00-30421.pdf.]

U.S. Environmental Protection Agency, 2004a, National water quality inventory: 2004 Report to Congress: EPA841-R-08-001, variously paged.

U.S. Environmental Protection Agency, 2004b, Sample preparation and calculations for dissolved gas analysis in water samples using a GC headspace equilibration technique, 14 p., accessed May 28, 2013, at http://www.epa. gov/region1/info/testmethods/pdfs/RSKsop175v2.pdf. 
U.S. Environmental Protection Agency, 2006, SunscreenThe burning facts: Washington D.C., EPA 430-F-06-013, 6 p., accessed December 18, 2012, at http://www2.epa.gov/ sites/production/files/documents/sunscreen.pdf.

U.S. Environmental Protection Agency, 2010, National priority chemicals trends report (2005-2007), section 4, Trends analyses for specific priority chemicals (20052007) - Phenanthrene: Washington, D.C., EPA 530-R-10011, 2 p., accessed December 18, 2012, at http://www.epa. gov/wastes/hazard/wastemin/minimize/trend10/sec4/part10. $p d f$.

U.S. Environmental Protection Agency, 2012a, Beta particles, 6 p., accessed December 18, 2012, at http://www.epa.gov/ rpdweb00/understand/beta.html.

U.S. Environmental Protection Agency, 2012b, PesticidesTopical and chemical fact sheets-The insect repellent DEET, 3 p., accessed December 18, 2012, at http://www. epa.gov/pesticides/factsheets/chemicals/deet.htm.

U.S. Environmental Protection Agency, 2012c, 2012 Edition of the drinking water standards and health advisories, $20 \mathrm{p}$., accessed May 19, 2014, at http://waterepa.gov/action/ advisories/drinking/upload/dwstandards2012.pdf.

U.S. Environmental Protection Agency, 2013a, Basic information about nitrate in drinking water. 2 p., accessed March 18, 2013, at http://water.epa.gov/drink/contaminants/ basicinformation/nitrate.cfm.

U.S. Environmental Protection Agency, 2013b, Basic information about the radionuclides in drinking water, $3 \mathrm{p}$., accessed March 12, 2013, at http://water.epa.gov/drink/ contaminants/basicinformation/radionuclides.cfm.

U.S. Environmental Protection Agency, 2013c, Basic information about pathogens and indicators in drinking water, 5 p., accessed March 18, 2013, at http://water.epa. gov/drink/contaminants/basicinformation/pathogens.cfm.

U.S. Geological Survey, variously dated, National field manual for the collection of water-quality data: U.S. Geological Survey Techniques of Water-Resources Investigations, book 9, chaps. A1-A9, available at http://pubs.water.usgs. gov/twri9A.
U.S. Geological Survey, 2014, U.S. Geological Survey National Water Information System, water-quality data for Wyoming-Web interface: accessed May 12, 2014, athttp://waterdata.usgs.gov/wy/nwis/qw.

Watermolen, J., 1999, 1:2,000,000-scale Hydrologic Units of the United States, U.S. Geological Survey Unnumbered Series undefined, available at http://pubs.er.usgs.gov/ publication/70046628.

Whiticar, M.J., 1999, Carbon and hydrogen isotope systematics of bacterial formation and oxidation of methane: Chemical Geology, v. 161, p. 291-314. [(Also available at $h t t p: / / d x$.doi.org/10.1016/S00092541(99)00092-3.]

Wyoming Department of Environmental Quality, 2005, Quality standards for groundwaters of Wyoming: Wyoming Department of Environmental Quality, chap. VIII, 21 p.

Wyoming Department of Environmental Quality, 2012, Wyoming nonpoint source management plan, 2012: accessed December 17, 2012, at http://deq.state.wy.us/wqd/ watershed/nps/NPS.htm.

Zaugg, S.D., Smith, S.G., Schroeder, M.P., Barber, L.B., and Burkhardt, M.R., 2007, Methods of analysis by the U.S. Geological Survey National Water Quality LaboratoryDetermination of wastewater compounds by polystyrenedivinylbenzene solid-phase extraction and capillarycolumn gas chromatography/mass spectrometry: U.S. Geological Survey Water-Resources Investigations Report 01-4186, 37 p. [Also available at http://pubs.usgs.gov/wri/ wri014186/.]

Zogorski, J.S., Carter, J.M., Ivahnenko, T., Lapham, W.W., Moran, M.J., Rowe, B.L., Squillace, P.J., and Toccalino, P.L., 2006, The quality of our Nation's waters-Volatile organic compounds in the Nation's ground water and drinking-water supply wells: U.S. Geological Survey Circular 1292, 101 p. [Also available at http://pubs.usgs. gov/circ/circ1292/.] 
Table 3. Well construction and ancillary data for wells sampled for the Wyoming Groundwater-Quality Monitoring Network, November 2009 through September 2012.

[NAVD 88, North American Vertical Datum of 1988; P, water-level measurement that was recorded on water rights permit; PVC, polyvinyl chloride; S, steel; --, data not available; I, iron; G, galvanized]

\begin{tabular}{|c|c|c|c|c|c|c|c|c|c|}
\hline $\begin{array}{l}\text { Hydrogeologic } \\
\text { unit }\end{array}$ & County & $\begin{array}{l}\text { U.S. Geological } \\
\text { Survey site } \\
\text { identification } \\
\text { number }\end{array}$ & $\begin{array}{c}\text { Field } \\
\text { identi- } \\
\text { fication } \\
\text { number }\end{array}$ & $\begin{array}{c}\text { Wyoming } \\
\text { State } \\
\text { Engineer's } \\
\text { Office well } \\
\text { permit } \\
\text { number }\end{array}$ & $\begin{array}{c}\text { Water } \\
\text { right } \\
\text { priority } \\
\text { date } \\
\text { (month/ } \\
\text { day/year) }\end{array}$ & $\begin{array}{c}\text { Well } \\
\text { construc- } \\
\text { tion date }\end{array}$ & $\begin{array}{c}\text { Date of } \\
\text { sampling } \\
\text { (month/ } \\
\text { day/year) }\end{array}$ & $\begin{array}{l}\text { Land- } \\
\text { surface } \\
\text { elevation } \\
\text { (feet } \\
\text { above } \\
\text { NAVD 88) }\end{array}$ & $\begin{array}{c}\text { Depth } \\
\text { of well } \\
\text { (feet } \\
\text { below } \\
\text { land } \\
\text { surface) }\end{array}$ \\
\hline $\begin{array}{l}\text { Quaternary unconsolidated- } \\
\text { deposit aquifers }\end{array}$ & Albany & 411309105494201 & ALB1 & P136903W & 7/31/2001 & $9 / 8 / 2001$ & $8 / 13 / 2012$ & 7,244 & 12 \\
\hline $\begin{array}{l}\text { Quaternary unconsolidated- } \\
\text { deposit aquifers }\end{array}$ & Albany & 411408106074101 & ALB19 & P192958W & $5 / 24 / 2010$ & $10 / 21 / 2010$ & 9/26/2012 & 7,906 & 50 \\
\hline $\begin{array}{l}\text { Quaternary unconsolidated- } \\
\text { deposit aquifers }\end{array}$ & Albany & 411749106005401 & ALB15 & P191207W & 8/5/2009 & $1 / 26 / 2010$ & 9/24/2012 & 7,568 & 67 \\
\hline $\begin{array}{l}\text { Quaternary unconsolidated- } \\
\text { deposit aquifers }\end{array}$ & Albany & 411916106084601 & ALB5 & P107025W & 8/12/1997 & 6/5/1998 & $8 / 15 / 2012$ & 8,352 & 194 \\
\hline $\begin{array}{l}\text { Quaternary unconsolidated- } \\
\text { deposit aquifers }\end{array}$ & Albany & 411922105371701 & ALB16 & P106412W & 6/27/1997 & 1996 & $9 / 25 / 2012$ & 7,165 & 20 \\
\hline $\begin{array}{l}\text { Quaternary unconsolidated- } \\
\text { deposit aquifers }\end{array}$ & Albany & 412350105522901 & ALB3 & P129254W & $9 / 20 / 2000$ & $7 / 7 / 2001$ & 8/14/2012 & 7,215 & 25 \\
\hline $\begin{array}{l}\text { Quaternary unconsolidated- } \\
\text { deposit aquifers }\end{array}$ & Albany & 414551105222701 & ALB13 & P73127W & 8/13/1986 & 10/11/1986 & 9/24/2012 & 6,093 & 30 \\
\hline $\begin{array}{l}\text { Quaternary unconsolidated- } \\
\text { deposit aquifers }\end{array}$ & Carbon & 410124107285501 & CAR2 & P16710P & $11 / 15 / 1955$ & 11/15/1955 & $6 / 29 / 2010$ & 6,425 & 40 \\
\hline $\begin{array}{l}\text { Quaternary unconsolidated- } \\
\text { deposit aquifers }\end{array}$ & Carbon & 410135107265701 & C7 & P126078W & $6 / 8 / 2000$ & 1975 & $7 / 1 / 2010$ & 6,480 & 52.54 \\
\hline $\begin{array}{l}\text { Quaternary unconsolidated- } \\
\text { deposit aquifers }\end{array}$ & Carbon & 410202107310501 & CAR4 & P19673P & $12 / 31 / 1900$ & 1900 & $6 / 30 / 2010$ & 6,390 & 25 \\
\hline $\begin{array}{l}\text { Quaternary unconsolidated- } \\
\text { deposit aquifers }\end{array}$ & Carbon & 410207107363701 & CAR1 & P143346W & $3 / 25 / 2002$ & $11 / 17 / 2004$ & $6 / 28 / 2010$ & 6,282 & 38.91 \\
\hline $\begin{array}{l}\text { Quaternary unconsolidated- } \\
\text { deposit aquifers }\end{array}$ & Carbon & 410208107392801 & C8 & P103657W & 9/5/1996 & -- & $6 / 29 / 2010$ & 6,245 & 11 \\
\hline $\begin{array}{l}\text { Quaternary unconsolidated- } \\
\text { deposit aquifers }\end{array}$ & Goshen & 413814104270301 & GOS3 & P10214P & $12 / 31 / 1965$ & -- & 7/13/2011 & 4,904 & 40 \\
\hline $\begin{array}{l}\text { Quaternary unconsolidated- } \\
\text { deposit aquifers }\end{array}$ & Goshen & 413816104135201 & GOS22 & P21973P & 3/21/1930 & 1930 & $10 / 17 / 2011$ & 4,596 & 40 \\
\hline $\begin{array}{l}\text { Quaternary unconsolidated- } \\
\text { deposit aquifers }\end{array}$ & Goshen & 420327104090001 & W54 & None & -- & -- & $10 / 3 / 2011$ & 4,085 & 29.77 \\
\hline $\begin{array}{l}\text { Quaternary unconsolidated- } \\
\text { deposit aquifers }\end{array}$ & Goshen & 420330104111001 & GOS17 & P69070W & $12 / 4 / 1984$ & 6/19/1985 & $10 / 3 / 2011$ & 4,096 & 128 \\
\hline $\begin{array}{l}\text { Quaternary unconsolidated- } \\
\text { deposit aquifers }\end{array}$ & Goshen & 420500104135101 & GOS16 & P60952W & 5/3/1982 & 7/15/1982 & 9/7/2011 & 4,126 & 80 \\
\hline $\begin{array}{l}\text { Quaternary unconsolidated- } \\
\text { deposit aquifers }\end{array}$ & Goshen & 420531104100201 & W21 & P96323W & 7/25/1994 & 8/5/1994 & $10 / 5 / 2011$ & 4,175 & 23 \\
\hline $\begin{array}{l}\text { Quaternary unconsolidated- } \\
\text { deposit aquifers }\end{array}$ & Goshen & 420636104205601 & GOS6 & P24462P & 6/12/1956 & 6/12/1956 & $7 / 26 / 2011$ & 4,144 & 100 \\
\hline $\begin{array}{l}\text { Quaternary unconsolidated- } \\
\text { deposit aquifers }\end{array}$ & Goshen & 420700104162801 & GOS12 & P114025W & 2/11/1999 & $2 / 1 / 2001$ & 8/24/2011 & 4,232 & 118 \\
\hline $\begin{array}{l}\text { Quaternary unconsolidated- } \\
\text { deposit aquifers }\end{array}$ & Goshen & 420747104225401 & GOS19 & P122018W & $1 / 19 / 2000$ & $10 / 1 / 2001$ & $10 / 4 / 2011$ & 4,160 & 35 \\
\hline $\begin{array}{l}\text { Quaternary unconsolidated- } \\
\text { deposit aquifers }\end{array}$ & Goshen & 420941104184501 & W19 & None & -- & -- & 10/18/2011 & 4,205 & 36 \\
\hline
\end{tabular}




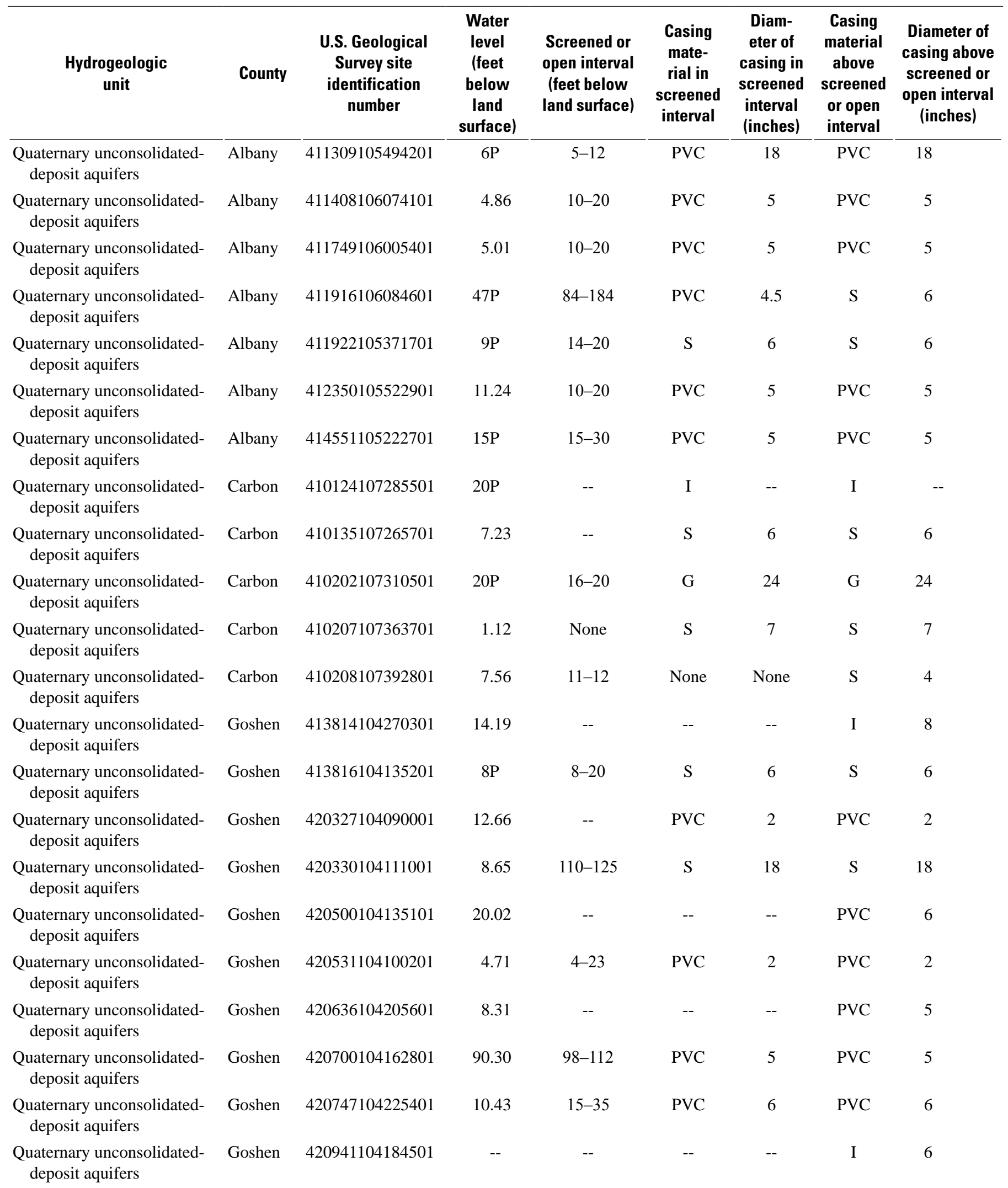


Table 3. Well construction and ancillary data for wells sampled for the Wyoming Groundwater-Quality Monitoring Network, November 2009 through September 2012. - Continued

[NAVD 88, North American Vertical Datum of 1988; P, water-level measurement that was recorded on water rights permit; PVC, polyvinyl chloride; S, steel; --, data not available; I, iron; G, galvanized]

\begin{tabular}{|c|c|c|c|c|c|c|c|c|c|}
\hline $\begin{array}{l}\text { Hydrogeologic } \\
\text { unit }\end{array}$ & County & $\begin{array}{l}\text { U.S. Geological } \\
\text { Survey site } \\
\text { identification } \\
\text { number }\end{array}$ & $\begin{array}{c}\text { Field } \\
\text { identi- } \\
\text { fication } \\
\text { number }\end{array}$ & $\begin{array}{c}\text { Wyoming } \\
\text { State } \\
\text { Engineer's } \\
\text { Office well } \\
\text { permit } \\
\text { number }\end{array}$ & $\begin{array}{c}\text { Water } \\
\text { right } \\
\text { priority } \\
\text { date } \\
\text { (month/ } \\
\text { day/year) }\end{array}$ & $\begin{array}{c}\text { Well } \\
\text { construc- } \\
\text { tion date }\end{array}$ & $\begin{array}{c}\text { Date of } \\
\text { sampling } \\
\text { (month/ } \\
\text { day/year) }\end{array}$ & $\begin{array}{c}\text { Land- } \\
\text { surface } \\
\text { elevation } \\
\text { (feet } \\
\text { above } \\
\text { NAVD 88) }\end{array}$ & $\begin{array}{c}\text { Depth } \\
\text { of well } \\
\text { (feet } \\
\text { below } \\
\text { land } \\
\text { surface) }\end{array}$ \\
\hline $\begin{array}{l}\text { Quaternary unconsolidated- } \\
\text { deposit aquifers }\end{array}$ & Goshen & 421203104345801 & GOS18 & P12053P & $10 / 10 / 1968$ & $10 / 12 / 1968$ & $10 / 17 / 2011$ & 4,259 & 33 \\
\hline $\begin{array}{l}\text { Quaternary unconsolidated- } \\
\text { deposit aquifers }\end{array}$ & Goshen & 421219104331901 & W6 & P6445W & 7/30/1970 & $11 / 19 / 1960$ & 8/23/2011 & 4,260 & 60 \\
\hline $\begin{array}{l}\text { Quaternary unconsolidated- } \\
\text { deposit aquifers }\end{array}$ & Goshen & 421353104170701 & GOS30 & P140391W & $10 / 30 / 2001$ & $11 / 19 / 2002$ & $5 / 21 / 2012$ & 4,274 & 26 \\
\hline $\begin{array}{l}\text { Quaternary unconsolidated- } \\
\text { deposit aquifers }\end{array}$ & Platte & 414530104481201 & PLA12 & None & 1/31/1949 & 1949 & 6/27/2012 & 5,268 & 50 \\
\hline $\begin{array}{l}\text { Quaternary unconsolidated- } \\
\text { deposit aquifers }\end{array}$ & Platte & 415111105125701 & PLA4 & P55147W & $1 / 15 / 1981$ & 1981 & 5/23/2012 & 5,320 & 50 \\
\hline $\begin{array}{l}\text { Quaternary unconsolidated- } \\
\text { deposit aquifers }\end{array}$ & Platte & 420709104491901 & T13 & P24065W & 4/3/1973 & 1959 & 6/5/2012 & 4,428 & 88 \\
\hline $\begin{array}{l}\text { Quaternary unconsolidated- } \\
\text { deposit aquifers }\end{array}$ & Platte & 421616104450001 & PLA5 & P34859W & 9/22/1976 & 1958 & 6/4/2012 & 4,342 & 50 \\
\hline $\begin{array}{l}\text { Quaternary unconsolidated- } \\
\text { deposit aquifers }\end{array}$ & Platte & 422611105103001 & PLA10 & P4772P & $12 / 31 / 1938$ & 8/10/1994 & 6/26/2012 & 4,947 & 30 \\
\hline $\begin{array}{l}\text { Quaternary unconsolidated- } \\
\text { deposit aquifers }\end{array}$ & Platte & 422749104591701 & $\mathrm{~T} 8$ & P81043W & 10/17/1989 & 10/28/1989 & 6/6/2012 & 4,553 & 40 \\
\hline $\begin{array}{l}\text { Quaternary unconsolidated- } \\
\text { deposit aquifers }\end{array}$ & Sublette & 425623110203101 & SUB5 & P76204W & $1 / 18 / 1988$ & 6/28/1988 & $9 / 1 / 2010$ & 7,665 & 21 \\
\hline $\begin{array}{l}\text { Quaternary unconsolidated- } \\
\text { deposit aquifers }\end{array}$ & Sublette & 430935110221001 & SUB4 & P143327W & 3/22/2002 & $2 / 28 / 2002$ & $9 / 1 / 2010$ & 6,820 & 37.95 \\
\hline $\begin{array}{l}\text { Quaternary unconsolidated- } \\
\text { deposit aquifers }\end{array}$ & $\begin{array}{l}\text { Sweet- } \\
\text { water }\end{array}$ & 413134109274301 & E6 & None & 9/18/1989 & 1989 & $12 / 17 / 2009$ & 6,080 & 14.7 \\
\hline $\begin{array}{l}\text { Quaternary unconsolidated- } \\
\text { deposit aquifers }\end{array}$ & $\begin{array}{l}\text { Sweet- } \\
\text { water }\end{array}$ & 413428109135201 & E8 & P80844W & 9/18/1989 & 10/23/1989 & $12 / 17 / 2009$ & 6,240 & 20 \\
\hline $\begin{array}{l}\text { Quaternary unconsolidated- } \\
\text { deposit aquifers }\end{array}$ & $\begin{array}{l}\text { Sweet- } \\
\text { water }\end{array}$ & 413454109133501 & E3 & P80842W & 9/18/1989 & $10 / 24 / 1989$ & $12 / 14 / 2009$ & 6,260 & 20 \\
\hline $\begin{array}{l}\text { Quaternary unconsolidated- } \\
\text { deposit aquifers }\end{array}$ & Uinta & 410411110074101 & U3 & P95874W & 6/17/1994 & 2/3/1995 & $8 / 2 / 2010$ & 7,400 & 45 \\
\hline $\begin{array}{l}\text { Quaternary unconsolidated- } \\
\text { deposit aquifers }\end{array}$ & Uinta & 411332110235301 & U8 & P36344W & 2/23/1977 & 6/10/1952 & 8/3/2010 & 7,060 & 50 \\
\hline $\begin{array}{l}\text { Quaternary unconsolidated- } \\
\text { deposit aquifers }\end{array}$ & Uinta & 411614110202801 & U9 & P124145W & $3 / 16 / 2000$ & $6 / 12 / 2000$ & 8/3/2010 & 6,810 & 12.95 \\
\hline $\begin{array}{l}\text { Quaternary unconsolidated- } \\
\text { deposit aquifers }\end{array}$ & Uinta & 411937110172801 & U10 & P124140W & $3 / 16 / 2000$ & $5 / 5 / 2000$ & 8/5/2010 & 6,700 & 11.26 \\
\hline $\begin{array}{l}\text { Quaternary unconsolidated- } \\
\text { deposit aquifers }\end{array}$ & Uinta & 412147110164101 & UIN2 & P30545W & 7/28/1975 & 1975 & $8 / 4 / 2010$ & 6,498 & 12.67 \\
\hline $\begin{array}{l}\text { Ogallala aquifer (High } \\
\text { Plains aquifer system) }\end{array}$ & Laramie & 410735104401201 & R10 & P19445P & 6/21/1925 & 1925 & $11 / 3 / 2010$ & 5,835 & 125 \\
\hline $\begin{array}{l}\text { Ogallala aquifer (High } \\
\text { Plains aquifer system) }\end{array}$ & Laramie & 410927104530001 & LAR5 & P66149W & $12 / 21 / 1983$ & $4 / 13 / 1984$ & $5 / 2 / 2011$ & 6,170 & 170 \\
\hline $\begin{array}{l}\text { Ogallala aquifer (High } \\
\text { Plains aquifer system) }\end{array}$ & Laramie & 410942104360601 & LAR8 & P72225W & 4/16/1986 & 9/1/1988 & 5/3/2011 & 5,872 & 460 \\
\hline
\end{tabular}




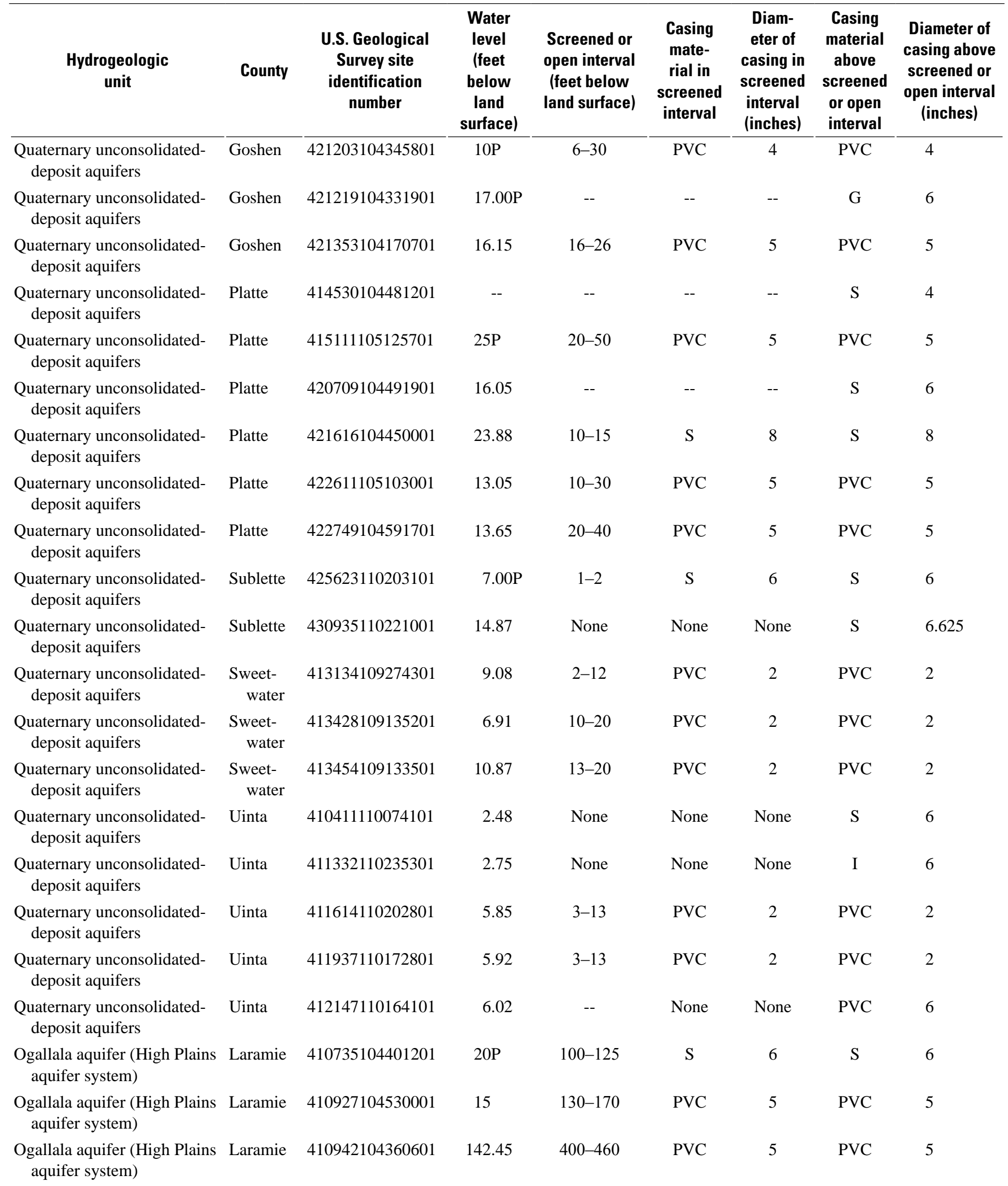


Table 3. Well construction and ancillary data for wells sampled for the Wyoming Groundwater-Quality Monitoring Network, November 2009 through September 2012. - Continued

[NAVD 88, North American Vertical Datum of 1988; P, water-level measurement that was recorded on water rights permit; PVC, polyvinyl chloride; S, steel; --, data not available; I, iron; G, galvanized]

\begin{tabular}{|c|c|c|c|c|c|c|c|c|c|}
\hline $\begin{array}{c}\text { Hydrogeologic } \\
\text { unit }\end{array}$ & County & $\begin{array}{l}\text { U.S. Geological } \\
\text { Survey site } \\
\text { identification } \\
\text { number }\end{array}$ & $\begin{array}{c}\text { Field } \\
\text { identi- } \\
\text { fication } \\
\text { number }\end{array}$ & $\begin{array}{c}\text { Wyoming } \\
\text { State } \\
\text { Engineer's } \\
\text { Office well } \\
\text { permit } \\
\text { number }\end{array}$ & $\begin{array}{l}\text { Water } \\
\text { right } \\
\text { priority } \\
\text { date } \\
\text { (month/ } \\
\text { day/year) }\end{array}$ & $\begin{array}{l}\text { Well } \\
\text { construc- } \\
\text { tion date }\end{array}$ & $\begin{array}{c}\text { Date of } \\
\text { sampling } \\
\text { (month/ } \\
\text { day/year) }\end{array}$ & $\begin{array}{l}\text { Land- } \\
\text { surface } \\
\text { elevation } \\
\text { (feet } \\
\text { above } \\
\text { NAVD 88) }\end{array}$ & $\begin{array}{c}\text { Depth } \\
\text { of well } \\
\text { (feet } \\
\text { below } \\
\text { land } \\
\text { surface) }\end{array}$ \\
\hline $\begin{array}{l}\text { Ogallala aquifer (High } \\
\text { Plains aquifer system) }\end{array}$ & Laramie & 411115104392401 & LAR7 & P94741W & 3/22/1994 & $5 / 29 / 1994$ & 5/3/2011 & 5,964 & 400 \\
\hline $\begin{array}{l}\text { Ogallala aquifer (High } \\
\text { Plains aquifer system) }\end{array}$ & Laramie & 411303104342001 & LAR4 & P123906W & $3 / 10 / 2000$ & 7/19/2000 & $12 / 1 / 2010$ & 5,792 & 360 \\
\hline $\begin{array}{l}\text { Ogallala aquifer (High } \\
\text { Plains aquifer system) }\end{array}$ & Laramie & 411355104464201 & LAR2 & P90686W & 1/26/1993 & $11 / 22 / 1993$ & $11 / 29 / 2010$ & 6,142 & 500 \\
\hline $\begin{array}{l}\text { Ogallala aquifer (High } \\
\text { Plains aquifer system) }\end{array}$ & Laramie & 411356104493001 & LAR14 & P142767W & 2/19/2002 & 7/1/2002 & 5/18/2011 & 6,215 & 480 \\
\hline $\begin{array}{l}\text { Ogallala aquifer (High } \\
\text { Plains aquifer system) }\end{array}$ & Laramie & 411836104133101 & LAR1 & P75812W & $11 / 3 / 1987$ & 1975 & $11 / 2 / 2010$ & 5,329 & 150 \\
\hline $\begin{array}{l}\text { Ogallala aquifer (High } \\
\text { Plains aquifer system) }\end{array}$ & Laramie & 411900104180001 & LAR20 & P18424P & 9/30/1952 & 1952 & 6/13/2011 & 5,488 & 170 \\
\hline $\begin{array}{l}\text { Ogallala aquifer (High } \\
\text { Plains aquifer system) }\end{array}$ & Laramie & 412117104365601 & LAR3 & P11293P & 6/30/1911 & 1911 & $11 / 30 / 2010$ & 5,904 & 125 \\
\hline $\begin{array}{l}\text { Arikaree aquifer (High } \\
\text { Plains aquifer system) }\end{array}$ & Goshen & 421733104260301 & GOS10 & P161354W & $8 / 12 / 2004$ & 7/5/2005 & $8 / 22 / 2011$ & 4,765 & 420 \\
\hline $\begin{array}{l}\text { Arikaree aquifer (High } \\
\text { Plains aquifer system) }\end{array}$ & Goshen & 422026104283801 & GOS21 & P94265W & 1/18/1994 & 4/5/1994 & $10 / 5 / 2011$ & 4,851 & 400 \\
\hline $\begin{array}{l}\text { Arikaree aquifer (High } \\
\text { Plains aquifer system) }\end{array}$ & Goshen & 423042104143801 & GOS9 & P18601P & 7/31/1963 & 1963 & $8 / 22 / 2011$ & 4,834 & 200 \\
\hline $\begin{array}{l}\text { Arikaree aquifer (High } \\
\text { Plains aquifer system) }\end{array}$ & Laramie & 410740104321801 & LAR10 & P141809W & $1 / 11 / 2002$ & $5 / 14 / 2002$ & 5/16/2011 & 5,767 & 260 \\
\hline $\begin{array}{l}\text { Arikaree aquifer (High } \\
\text { Plains aquifer system) }\end{array}$ & Laramie & 410829104250301 & LAR13 & P98664W & 4/3/1995 & 9/1/1995 & 5/17/2011 & 5,591 & 205 \\
\hline $\begin{array}{l}\text { Arikaree aquifer (High } \\
\text { Plains aquifer system) }\end{array}$ & Laramie & 411522104243401 & LAR18 & P1894W & 8/5/1966 & 8/10/1967 & 6/1/2011 & 5,610 & 260 \\
\hline $\begin{array}{l}\text { Arikaree aquifer (High } \\
\text { Plains aquifer system) }\end{array}$ & Laramie & 411930104210101 & LAR23 & P33612W & 6/10/1976 & 8/2/1976 & $6 / 14 / 2011$ & 5,588 & 250 \\
\hline $\begin{array}{l}\text { Arikaree aquifer (High } \\
\text { Plains aquifer system) }\end{array}$ & Laramie & 412534104285001 & LAR9 & P5756P & $12 / 10 / 1941$ & $12 / 10 / 1941$ & $5 / 4 / 2011$ & 5,753 & 380 \\
\hline $\begin{array}{l}\text { Arikaree aquifer (High } \\
\text { Plains aquifer system) }\end{array}$ & Platte & 414516104442601 & PLA2 & P60579W & 9/28/1981 & 7/3/1982 & $5 / 22 / 2012$ & 5,453 & 165 \\
\hline $\begin{array}{l}\text { Arikaree aquifer (High } \\
\text { Plains aquifer system) }\end{array}$ & Platte & 415406104415401 & PLA21 & P186982W & $6 / 2 / 2008$ & -- & 8/1/2012 & 5,196 & 230 \\
\hline $\begin{array}{l}\text { Arikaree aquifer (High } \\
\text { Plains aquifer system) }\end{array}$ & Platte & 415425105060801 & PLA23 & P28940W & $1 / 29 / 1975$ & 6/1/1975 & 9/12/2012 & 5,185 & 410 \\
\hline $\begin{array}{l}\text { Arikaree aquifer (High } \\
\text { Plains aquifer system) }\end{array}$ & Platte & 415819105014901 & PLA3 & P119430W & 10/6/1999 & 11/13/1999 & $5 / 23 / 2012$ & 5,028 & 50 \\
\hline $\begin{array}{l}\text { Arikaree aquifer (High } \\
\text { Plains aquifer system) }\end{array}$ & Platte & 420149104454301 & PLA11 & P11524P & $12 / 31 / 1915$ & $12 / 31 / 1915$ & 6/27/2012 & 5,065 & 280 \\
\hline $\begin{array}{l}\text { Arikaree aquifer (High } \\
\text { Plains aquifer system) }\end{array}$ & Platte & 420151105011401 & PLA7 & P30460W & 7/21/1975 & 9/24/1976 & 6/5/2012 & 4,850 & 100 \\
\hline $\begin{array}{l}\text { Arikaree aquifer (High } \\
\text { Plains aquifer system) }\end{array}$ & Platte & 420252104532401 & PLA16 & P142359W & 2/4/2002 & 2002 & 7/11/2012 & 4,565 & 230 \\
\hline
\end{tabular}




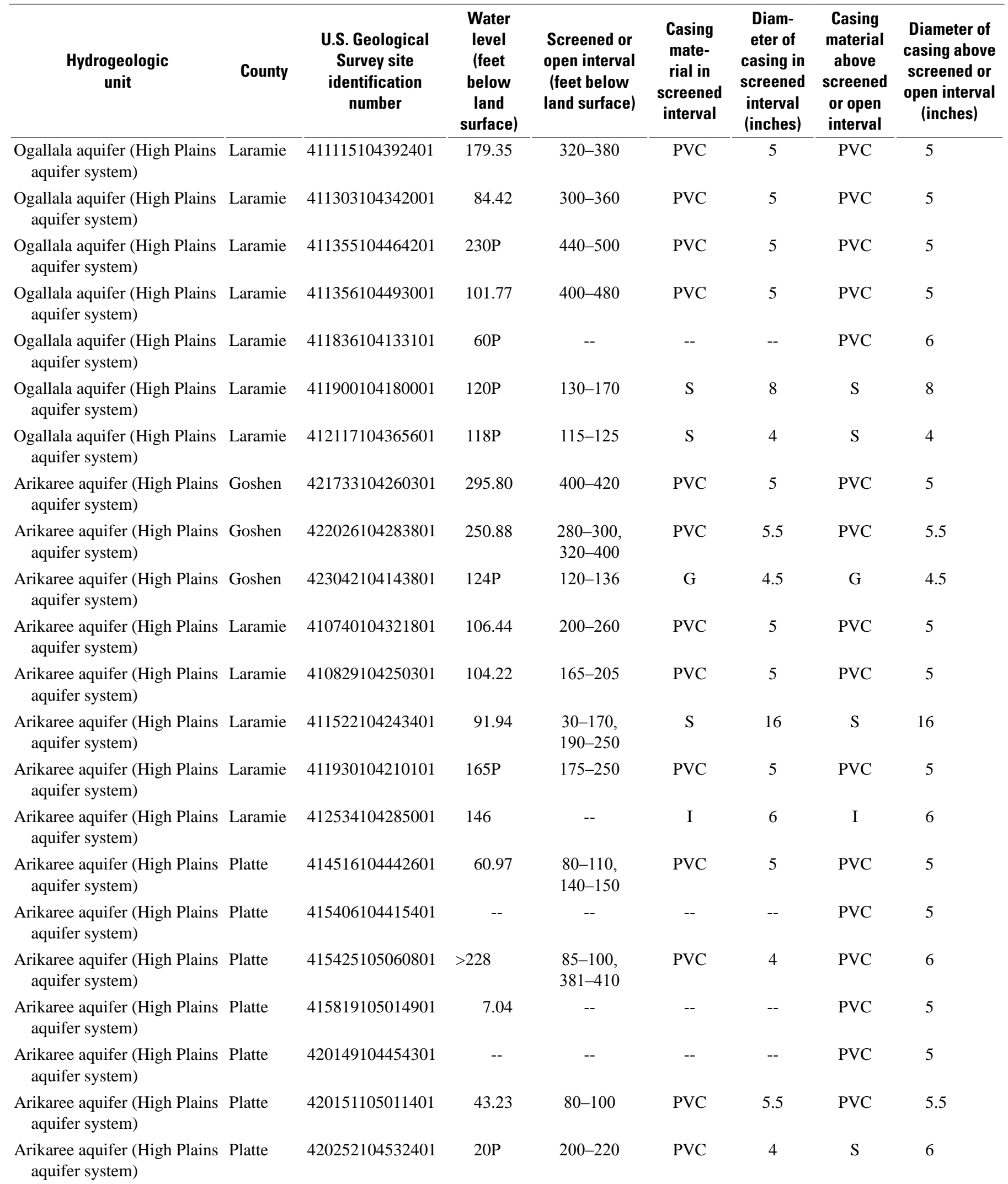


Table 3. Well construction and ancillary data for wells sampled for the Wyoming Groundwater-Quality Monitoring Network, November 2009 through September 2012.-Continued

[NAVD 88, North American Vertical Datum of 1988; P, water-level measurement that was recorded on water rights permit; PVC, polyvinyl chloride; S, steel; --, data not available; I, iron; G, galvanized]

\begin{tabular}{|c|c|c|c|c|c|c|c|c|c|}
\hline $\begin{array}{l}\text { Hydrogeologic } \\
\text { unit }\end{array}$ & County & $\begin{array}{l}\text { U.S. Geological } \\
\text { Survey site } \\
\text { identification } \\
\text { number }\end{array}$ & $\begin{array}{c}\text { Field } \\
\text { identi- } \\
\text { fication } \\
\text { number }\end{array}$ & $\begin{array}{c}\text { Wyoming } \\
\text { State } \\
\text { Engineer's } \\
\text { Office well } \\
\text { permit } \\
\text { number }\end{array}$ & $\begin{array}{c}\text { Water } \\
\text { right } \\
\text { priority } \\
\text { date } \\
\text { (month/ } \\
\text { day/year) }\end{array}$ & $\begin{array}{c}\text { Well } \\
\text { construc- } \\
\text { tion date }\end{array}$ & $\begin{array}{c}\text { Date of } \\
\text { sampling } \\
\text { (month/ } \\
\text { day/year) }\end{array}$ & $\begin{array}{c}\text { Land- } \\
\text { surface } \\
\text { elevation } \\
\text { (feet } \\
\text { above } \\
\text { NAVD 88) }\end{array}$ & $\begin{array}{c}\text { Depth } \\
\text { of well } \\
\text { (feet } \\
\text { below } \\
\text { land } \\
\text { surface) }\end{array}$ \\
\hline $\begin{array}{l}\text { Arikaree aquifer (High } \\
\text { Plains aquifer system) }\end{array}$ & Platte & 420425104560901 & PLA15 & P78609W & $12 / 6 / 1988$ & $5 / 18 / 2004$ & $7 / 11 / 2012$ & 4,707 & 260 \\
\hline $\begin{array}{l}\text { Arikaree aquifer (High } \\
\text { Plains aquifer system) }\end{array}$ & Platte & 420626105022801 & PLA22 & P47312W & $4 / 12 / 1979$ & 7/26/1979 & $8 / 27 / 2012$ & 4,626 & 157 \\
\hline $\begin{array}{l}\text { Arikaree aquifer (High } \\
\text { Plains aquifer system) }\end{array}$ & Platte & 421308104435901 & PLA17 & P191574W & $9 / 16 / 2009$ & $12 / 27 / 2010$ & 7/30/2012 & 4,419 & 250 \\
\hline $\begin{array}{l}\text { Arikaree aquifer (High } \\
\text { Plains aquifer system) }\end{array}$ & Platte & 421354104531701 & PLA19 & P132590W & $2 / 14 / 2001$ & $1 / 20 / 2002$ & 7/31/2012 & 4,791 & 400 \\
\hline $\begin{array}{l}\text { Arikaree aquifer (High } \\
\text { Plains aquifer system) }\end{array}$ & Platte & 421409104542701 & PLA20 & P47204W & 3/28/1979 & -- & 7/31/2012 & 4,902 & 350 \\
\hline $\begin{array}{l}\text { Arikaree aquifer (High } \\
\text { Plains aquifer system) }\end{array}$ & Platte & 421519104565101 & PLA14 & P3928P & 7/31/1962 & 1962 & 7/10/2012 & 4,805 & 260 \\
\hline $\begin{array}{l}\text { Arikaree aquifer (High } \\
\text { Plains aquifer system) }\end{array}$ & Platte & 422526104415801 & PLA6 & P127936W & $8 / 16 / 2000$ & $8 / 30 / 2000$ & 6/4/2012 & 5,179 & 200 \\
\hline $\begin{array}{l}\text { Brule aquifer (High Plains } \\
\text { aquifer system) }\end{array}$ & Goshen & 413756104095601 & GOS25 & P7461P & 10/31/1951 & 1951 & 10/19/2011 & 4,586 & 100 \\
\hline $\begin{array}{l}\text { Brule aquifer (High Plains } \\
\text { aquifer system) }\end{array}$ & Goshen & 420702104270201 & GOS8 & None & -- & -- & $7 / 27 / 2011$ & 4,319 & 120 \\
\hline $\begin{array}{l}\text { Brule aquifer (High Plains } \\
\text { aquifer system) }\end{array}$ & Laramie & 410108104223501 & $\mathrm{R} 4$ & None & -- & -- & $11 / 3 / 2010$ & 5,372 & 80 \\
\hline $\begin{array}{l}\text { Brule aquifer (High Plains } \\
\text { aquifer system) }\end{array}$ & Laramie & 410223104065901 & LAR27 & P22514P & 2/6/1973 & 10/17/2007 & 7/13/2011 & 5,194 & 114.22 \\
\hline $\begin{array}{l}\text { Brule aquifer (High Plains } \\
\text { aquifer system) }\end{array}$ & Laramie & 410324104101201 & LAR21 & P152035W & $6 / 23 / 2003$ & 10/18/2002 & 6/13/2011 & 5,235 & 330 \\
\hline $\begin{array}{l}\text { Brule aquifer (High Plains } \\
\text { aquifer system) }\end{array}$ & Laramie & 410837104065001 & LAR25 & P113537W & 1/19/1999 & 6/29/1999 & $7 / 12 / 2011$ & 5,116 & 260 \\
\hline $\begin{array}{l}\text { Brule aquifer (High Plains } \\
\text { aquifer system) }\end{array}$ & Laramie & 411012104152001 & LAR24 & P36288W & $2 / 25 / 1977$ & $5 / 23 / 1977$ & 6/15/2011 & 5,290 & 100 \\
\hline $\begin{array}{l}\text { Brule aquifer (High Plains } \\
\text { aquifer system) }\end{array}$ & Laramie & 411019104051301 & R7 & P63473W & 2/15/1983 & 1983 & $11 / 1 / 2010$ & 5,062 & 243 \\
\hline $\begin{array}{l}\text { Brule aquifer (High Plains } \\
\text { aquifer system) }\end{array}$ & Laramie & 411953104070301 & LAR22 & P8208P & $1 / 1 / 1908$ & $1 / 1 / 1908$ & $6 / 14 / 2011$ & 5,324 & 220 \\
\hline $\begin{array}{l}\text { Brule aquifer (High Plains } \\
\text { aquifer system) }\end{array}$ & Platte & 415030104421201 & PLA9 & P115348W & 4/23/1999 & $9 / 22 / 2004$ & $6 / 25 / 2012$ & 5,244 & 140 \\
\hline $\begin{array}{l}\text { Brule aquifer (High Plains } \\
\text { aquifer system) }\end{array}$ & Platte & 415325104445501 & PLA18 & P11576W & 12/31/1920 & 1920 & 8/27/2012 & 5,201 & 184.8 \\
\hline $\begin{array}{l}\text { Chadron aquifer (High } \\
\text { Plains aquifer system) }\end{array}$ & Goshen & 414948104065101 & GOS4 & P169582W & $8 / 23 / 2005$ & $10 / 7 / 2005$ & $7 / 25 / 2011$ & 4,202 & 138 \\
\hline $\begin{array}{l}\text { Chadron aquifer (High } \\
\text { Plains aquifer system) }\end{array}$ & Goshen & 415028104042701 & GOS20 & P28200P & 10/23/1974 & 1931 & $10 / 4 / 2011$ & 4,184 & 85 \\
\hline $\begin{array}{l}\text { Chadron aquifer (High } \\
\text { Plains aquifer system) }\end{array}$ & Goshen & 415425104062501 & GOS14 & P17542P & 12/31/1927 & 1927 & 9/6/2011 & 4,206 & 180 \\
\hline
\end{tabular}




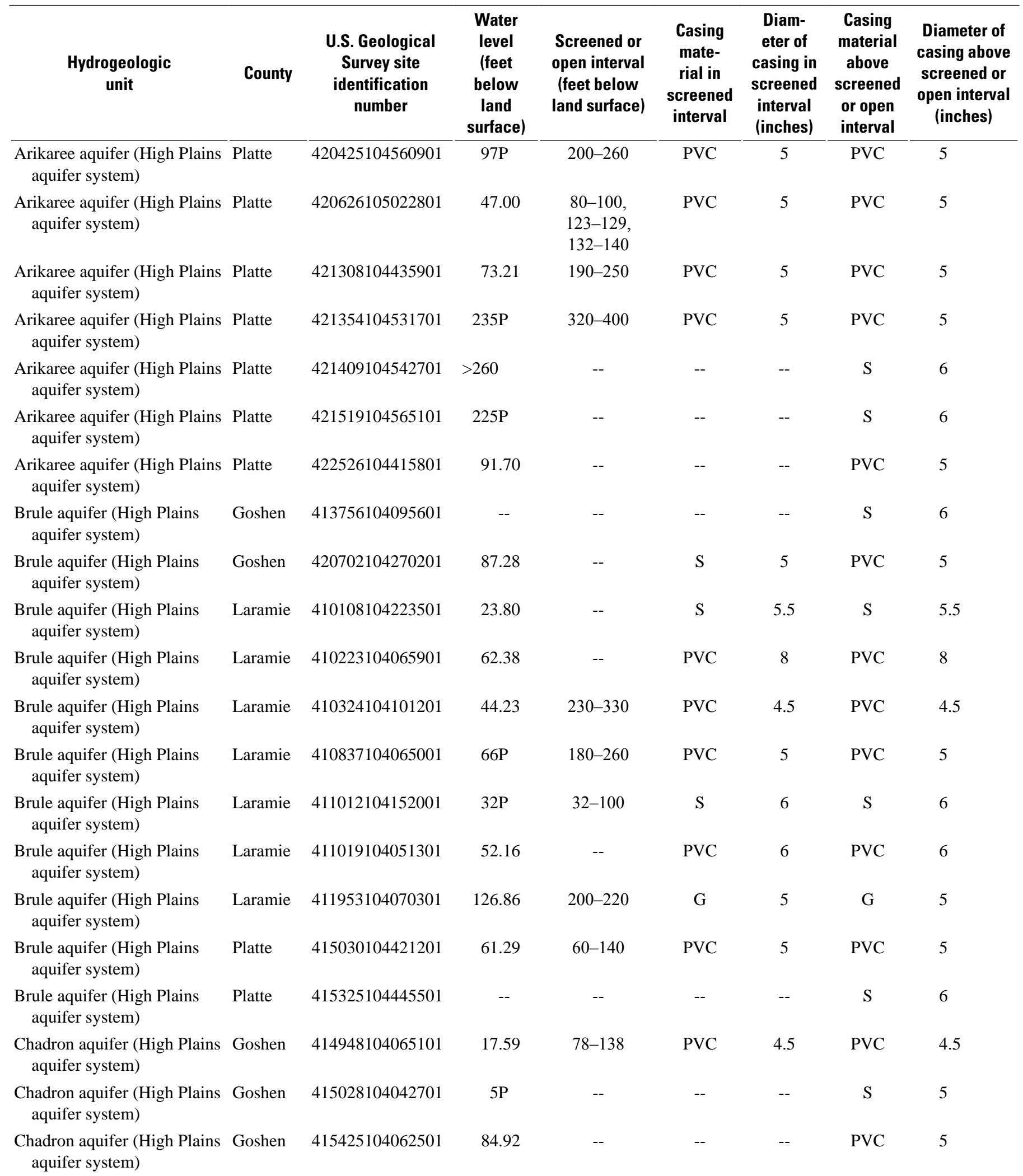


Table 3. Well construction and ancillary data for wells sampled for the Wyoming Groundwater-Quality Monitoring Network, November 2009 through September 2012. - Continued

[NAVD 88, North American Vertical Datum of 1988; P, water-level measurement that was recorded on water rights permit; PVC, polyvinyl chloride; S, steel; --, data not available; I, iron; G, galvanized]

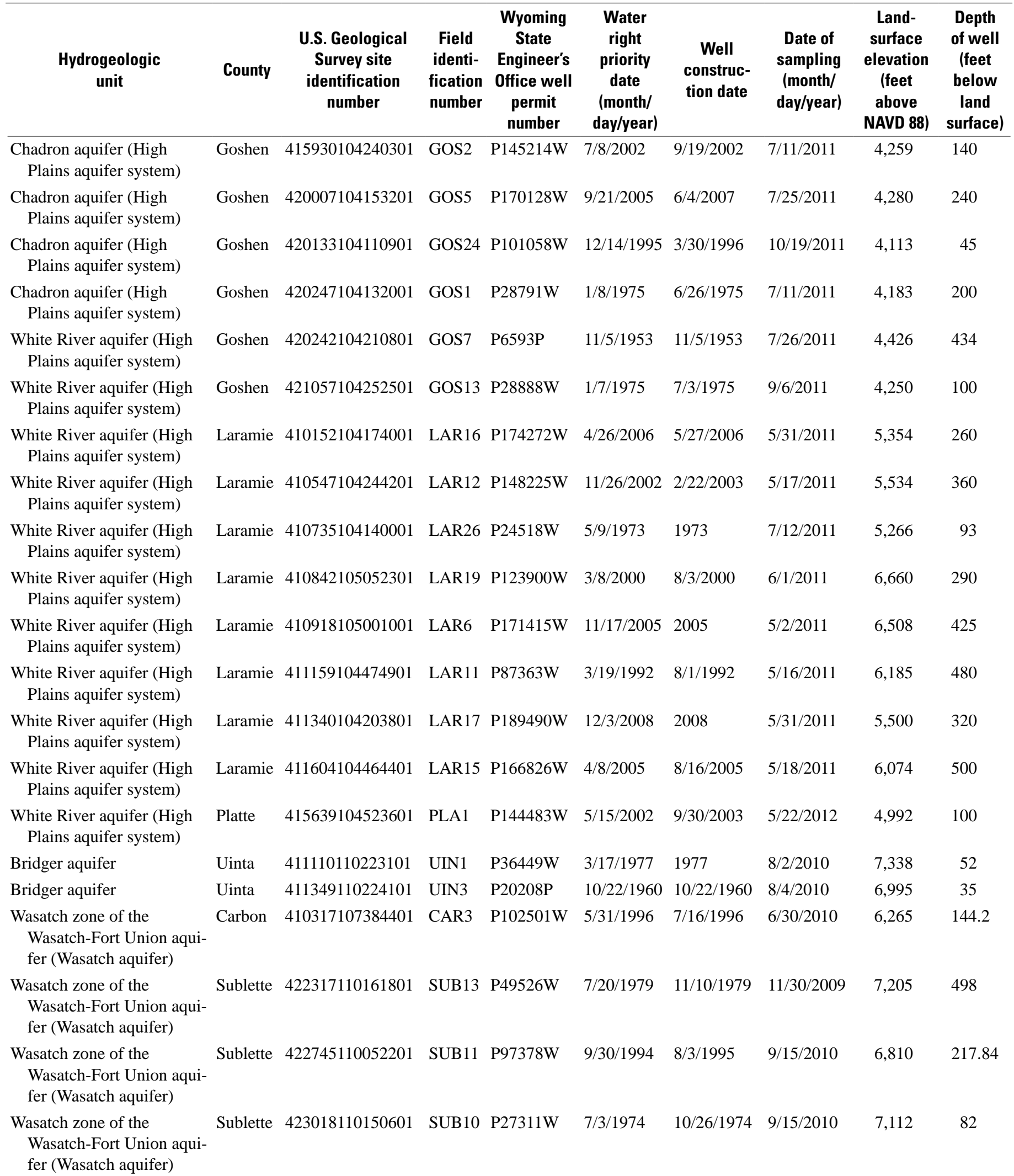




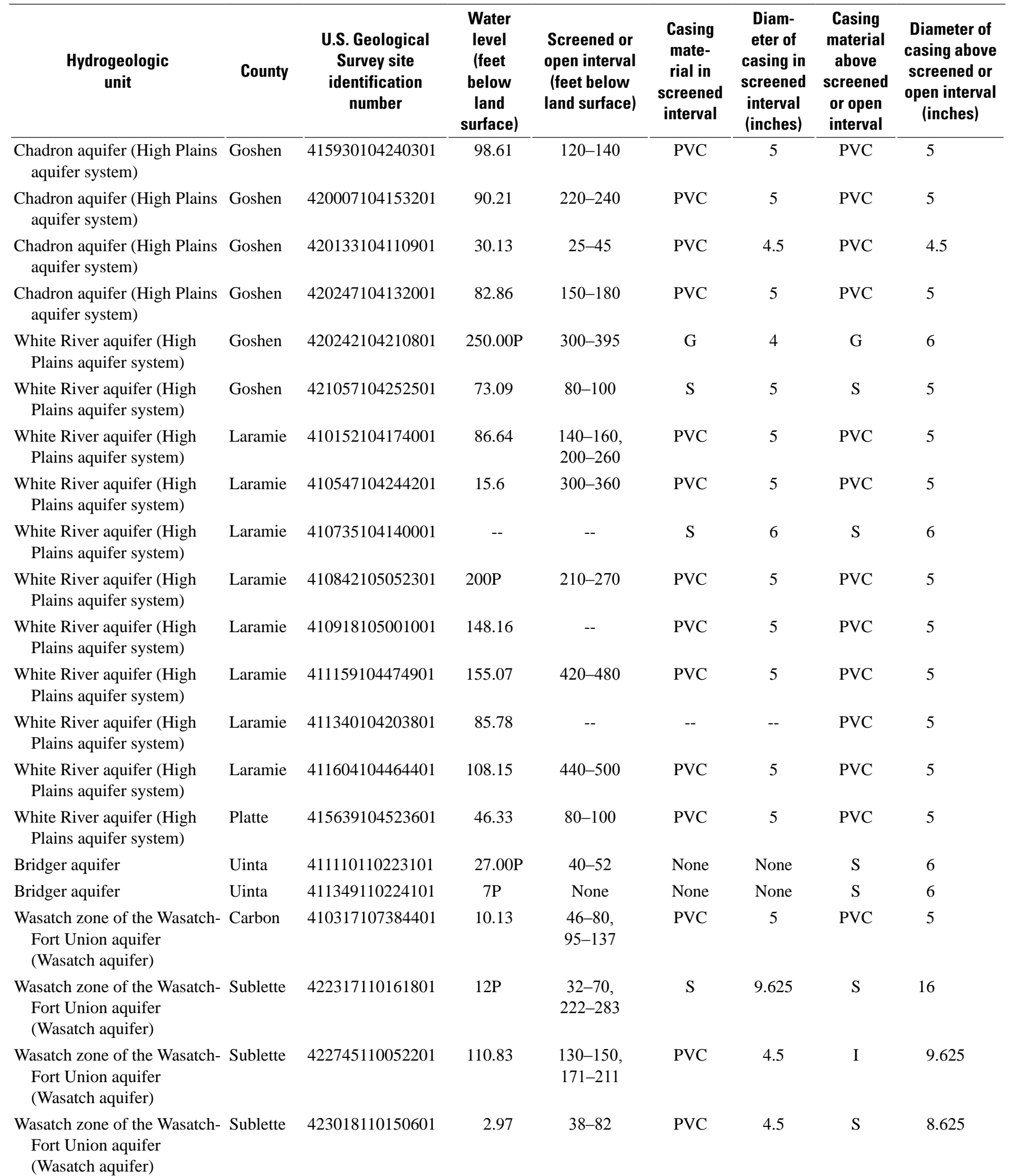


Table 3. Well construction and ancillary data for wells sampled for the Wyoming Groundwater-Quality Monitoring Network, November 2009 through September 2012.-Continued

[NAVD 88, North American Vertical Datum of 1988; P, water-level measurement that was recorded on water rights permit; PVC, polyvinyl chloride; S, steel; --, data not available; I, iron; G, galvanized]

\begin{tabular}{|c|c|c|c|c|c|c|c|c|c|}
\hline $\begin{array}{c}\text { Hydrogeologic } \\
\text { unit }\end{array}$ & County & $\begin{array}{l}\text { U.S. Geological } \\
\text { Survey site } \\
\text { identification } \\
\text { number }\end{array}$ & $\begin{array}{l}\text { Field } \\
\text { identi- } \\
\text { fication } \\
\text { number }\end{array}$ & $\begin{array}{c}\text { Wyoming } \\
\text { State } \\
\text { Engineer's } \\
\text { Office well } \\
\text { permit } \\
\text { number }\end{array}$ & $\begin{array}{c}\text { Water } \\
\text { right } \\
\text { priority } \\
\text { date } \\
\text { (month/ } \\
\text { day/year) }\end{array}$ & $\begin{array}{l}\text { Well } \\
\text { construc- } \\
\text { tion date }\end{array}$ & $\begin{array}{c}\text { Date of } \\
\text { sampling } \\
\text { (month/ } \\
\text { day/year) }\end{array}$ & $\begin{array}{c}\text { Land- } \\
\text { surface } \\
\text { elevation } \\
\text { (feet } \\
\text { above } \\
\text { NAVD 88) }\end{array}$ & $\begin{array}{c}\text { Depth } \\
\text { of well } \\
\text { (feet } \\
\text { below } \\
\text { land } \\
\text { surface) }\end{array}$ \\
\hline $\begin{array}{l}\text { Wasatch zone of the } \\
\text { Wasatch-Fort Union aqui- } \\
\text { fer (Wasatch aquifer) }\end{array}$ & Sublette & 423229110072401 & SUB6 & P116643W & $6 / 21 / 1999$ & 1999 & 9/13/2010 & 6,825 & 237 \\
\hline $\begin{array}{l}\text { Wasatch zone of the } \\
\text { Wasatch-Fort Union aqui- } \\
\text { fer (Wasatch aquifer) }\end{array}$ & Sublette & 423338110083201 & $\mathrm{~S} 10$ & P20189P & $12 / 31 / 1958$ & 1958 & $12 / 2 / 2009$ & 6,890 & 80 \\
\hline $\begin{array}{l}\text { Wasatch zone of the } \\
\text { Wasatch-Fort Union aqui- } \\
\text { fer (Wasatch aquifer) }\end{array}$ & Sublette & 423617110100501 & SUB9 & P150309W & 4/8/2003 & $5 / 20 / 1979$ & $9 / 14 / 2010$ & 7,030 & 155 \\
\hline $\begin{array}{l}\text { Wasatch zone of the } \\
\text { Wasatch-Fort Union aqui- } \\
\text { fer (Wasatch aquifer) }\end{array}$ & Sublette & 423638110030101 & SUB7 & P154136W & $9 / 24 / 2003$ & $6 / 1 / 2004$ & $9 / 13 / 2010$ & 6,870 & 420 \\
\hline $\begin{array}{l}\text { Wasatch zone of the } \\
\text { Wasatch-Fort Union aqui- } \\
\text { fer (Wasatch aquifer) }\end{array}$ & Sublette & 423703110182401 & SUB15 & P114187W & 10/21/1998 & $11 / 4 / 1999$ & $12 / 1 / 2009$ & 7,400 & 297 \\
\hline $\begin{array}{l}\text { Wasatch zone of the } \\
\text { Wasatch-Fort Union aqui- } \\
\text { fer (Wasatch aquifer) }\end{array}$ & Sublette & 423756109574001 & SUB16 & P85576W & 7/11/1991 & 7/28/1991 & $12 / 2 / 2009$ & 6,900 & 81 \\
\hline $\begin{array}{l}\text { Wasatch zone of the } \\
\text { Wasatch-Fort Union aqui- } \\
\text { fer (Wasatch aquifer) }\end{array}$ & Sublette & 425147110041801 & S7 & P84279W & $1 / 14 / 1991$ & 3/20/1991 & $8 / 18 / 2010$ & 7,195 & 105 \\
\hline $\begin{array}{l}\text { Wasatch zone of the } \\
\text { Wasatch-Fort Union aqui- } \\
\text { fer (Wasatch aquifer) }\end{array}$ & Sublette & 425256109581201 & SUB20 & P147900W & $11 / 4 / 2002$ & 3/20/2003 & 9/21/2011 & 7,252 & 223 \\
\hline $\begin{array}{l}\text { Wasatch zone of the } \\
\text { Wasatch-Fort Union aqui- } \\
\text { fer (Wasatch aquifer) }\end{array}$ & Sublette & 425308109530901 & SUB21 & P159955W & $6 / 25 / 2004$ & $10 / 12 / 2004$ & 9/22/2011 & 7,293 & 300 \\
\hline $\begin{array}{l}\text { Wasatch zone of the } \\
\text { Wasatch-Fort Union aqui- } \\
\text { fer (Wasatch aquifer) }\end{array}$ & Sublette & 425633110142401 & S3 & P110147W & 5/18/1998 & 7/7/1998 & $8 / 19 / 2010$ & 7,435 & 95 \\
\hline $\begin{array}{l}\text { Wasatch zone of the } \\
\text { Wasatch-Fort Union aqui- } \\
\text { fer (Wasatch aquifer) }\end{array}$ & Sublette & 425830110204401 & SUB1 & P190372W & $5 / 19 / 2009$ & 2009 & $8 / 30 / 2010$ & 8,060 & 130 \\
\hline $\begin{array}{l}\text { Wasatch zone of the } \\
\text { Wasatch-Fort Union aqui- } \\
\text { fer (Wasatch aquifer) }\end{array}$ & Sublette & 430107110041301 & SUB3 & P38812W & $5 / 24 / 1977$ & 8/19/1978 & $8 / 31 / 2010$ & 7,537 & 200 \\
\hline $\begin{array}{l}\text { Wasatch zone of the } \\
\text { Wasatch-Fort Union aqui- } \\
\text { fer (Wasatch aquifer) }\end{array}$ & Sublette & 430322110003301 & SUB17 & P70933W & 8/19/1985 & 10/17/1986 & 9/20/2011 & 7,624 & 180 \\
\hline $\begin{array}{l}\text { Wasatch zone of the } \\
\text { Wasatch-Fort Union aqui- } \\
\text { fer (Wasatch aquifer) }\end{array}$ & Sublette & 430633110011301 & SUB2 & P146491W & $8 / 12 / 2002$ & $10 / 30 / 2002$ & $8 / 31 / 2010$ & 7,820 & 160 \\
\hline $\begin{array}{l}\text { Farson Sandstone-Alkali } \\
\text { Creek aquifer (Alkali } \\
\text { Creek Tongue of the } \\
\text { Wasatch Formation) }\end{array}$ & Sublette & 423540109554801 & SUB8 & P28680W & $12 / 4 / 1974$ & 9/3/1973 & $9 / 14 / 2010$ & 6,962 & 172 \\
\hline
\end{tabular}




\begin{tabular}{|c|c|c|c|c|c|c|c|c|}
\hline $\begin{array}{c}\text { Hydrogeologic } \\
\text { unit }\end{array}$ & County & $\begin{array}{l}\text { U.S. Geological } \\
\text { Survey site } \\
\text { identification } \\
\text { number }\end{array}$ & $\begin{array}{c}\text { Water } \\
\text { level } \\
\text { (feet } \\
\text { below } \\
\text { land } \\
\text { surface) }\end{array}$ & $\begin{array}{l}\text { Screened or } \\
\text { open interval } \\
\text { (feet below } \\
\text { land surface) }\end{array}$ & $\begin{array}{l}\text { Casing } \\
\text { mate- } \\
\text { rial in } \\
\text { screened } \\
\text { interval }\end{array}$ & $\begin{array}{l}\text { Diam- } \\
\text { eter of } \\
\text { casing in } \\
\text { screened } \\
\text { interval } \\
\text { (inches) }\end{array}$ & $\begin{array}{l}\text { Casing } \\
\text { material } \\
\text { above } \\
\text { screened } \\
\text { or open } \\
\text { interval }\end{array}$ & $\begin{array}{l}\text { Diameter of } \\
\text { casing above } \\
\text { screened or } \\
\text { open interval } \\
\text { (inches) }\end{array}$ \\
\hline $\begin{array}{l}\text { Wasatch zone of the Wasatch- } \\
\text { Fort Union aquifer } \\
\text { (Wasatch aquifer) }\end{array}$ & Sublette & 423229110072401 & $20 \mathrm{P}$ & -- & $\mathrm{S}$ & 14 & $\mathrm{~S}$ & 14 \\
\hline $\begin{array}{l}\text { Wasatch zone of the Wasatch- } \\
\text { Fort Union aquifer } \\
\text { (Wasatch aquifer) }\end{array}$ & Sublette & 423338110083201 & 6.77 & -- & -- & -- & I & 6 \\
\hline $\begin{array}{l}\text { Wasatch zone of the Wasatch- } \\
\text { Fort Union aquifer } \\
\text { (Wasatch aquifer) }\end{array}$ & Sublette & 423617110100501 & $55 \mathrm{P}$ & $128-155$ & $\mathrm{~S}$ & 5.5 & $\mathrm{~S}$ & 8.625 \\
\hline $\begin{array}{l}\text { Wasatch zone of the Wasatch- } \\
\text { Fort Union aquifer } \\
\text { (Wasatch aquifer) }\end{array}$ & Sublette & 423703110182401 & $50 \mathrm{P}$ & $210-270$ & PVC & 6 & PVC & 6 \\
\hline $\begin{array}{l}\text { Wasatch zone of the Wasatch- } \\
\text { Fort Union aquifer } \\
\text { (Wasatch aquifer) }\end{array}$ & Sublette & 423756109574001 & 18.25 & $60-80$ & PVC & 4.5 & $\mathrm{~S}$ & 6 \\
\hline $\begin{array}{l}\text { Wasatch zone of the Wasatch- } \\
\text { Fort Union aquifer } \\
\text { (Wasatch aquifer) }\end{array}$ & Sublette & 425147110041801 & $12.5 \mathrm{P}$ & $65-105$ & PVC & 6.625 & $\mathrm{~S}$ & 8.625 \\
\hline $\begin{array}{l}\text { Wasatch zone of the Wasatch- } \\
\text { Fort Union aquifer } \\
\text { (Wasatch aquifer) }\end{array}$ & Sublette & 425256109581201 & $65 \mathrm{P}$ & $23-223$ & PVC & 4.5 & $\mathrm{~S}$ & 6 \\
\hline $\begin{array}{l}\text { Wasatch zone of the Wasatch- } \\
\text { Fort Union aquifer } \\
\text { (Wasatch aquifer) }\end{array}$ & Sublette & 425830110204401 & -- & -- & -- & -- & $\mathrm{S}$ & 6 \\
\hline $\begin{array}{l}\text { Wasatch zone of the Wasatch- } \\
\text { Fort Union aquifer } \\
\text { (Wasatch aquifer) }\end{array}$ & Sublette & 430107110041301 & $65 \mathrm{P}$ & $160-200$ & PVC & 4.625 & PVC & 4.625 \\
\hline $\begin{array}{l}\text { Wasatch zone of the Wasatch- } \\
\text { Fort Union aquifer } \\
\text { (Wasatch aquifer) }\end{array}$ & Sublette & 430322110003301 & 40.93 & $\begin{array}{c}125-140 \\
155-170\end{array}$ & PVC & 6.625 & $\mathrm{~S}$ & 8.625 \\
\hline $\begin{array}{l}\text { Wasatch zone of the Wasatch- } \\
\text { Fort Union aquifer } \\
\text { (Wasatch aquifer) }\end{array}$ & Sublette & 430633110011301 & 43.68 & $120-160$ & PVC & 4.5 & $\mathrm{~S}$ & 6 \\
\hline $\begin{array}{l}\text { Farson Sandstone-Alkali } \\
\text { Creek aquifer (Al- } \\
\text { kali Creek Tongue of the } \\
\text { Wasatch Formation) }\end{array}$ & Sublette & 423540109554801 & $75 \mathrm{P}$ & -- & -- & -- & $\mathrm{S}$ & 6.625 \\
\hline
\end{tabular}


Table 3. Well construction and ancillary data for wells sampled for the Wyoming Groundwater-Quality Monitoring Network, November 2009 through September 2012.-Continued

[NAVD 88, North American Vertical Datum of 1988; P, water-level measurement that was recorded on water rights permit; PVC, polyvinyl chloride; S, steel; --, data not available; I, iron; G, galvanized]

\begin{tabular}{|c|c|c|c|c|c|c|c|c|c|}
\hline $\begin{array}{c}\text { Hydrogeologic } \\
\text { unit }\end{array}$ & County & $\begin{array}{l}\text { U.S. Geological } \\
\text { Survey site } \\
\text { identification } \\
\text { number }\end{array}$ & $\begin{array}{l}\text { Field } \\
\text { identi- } \\
\text { fication } \\
\text { number }\end{array}$ & $\begin{array}{c}\text { Wyoming } \\
\text { State } \\
\text { Engineer's } \\
\text { Office well } \\
\text { permit } \\
\text { number }\end{array}$ & $\begin{array}{c}\text { Water } \\
\text { right } \\
\text { priority } \\
\text { date } \\
\text { (month/ } \\
\text { day/year) }\end{array}$ & $\begin{array}{l}\text { Well } \\
\text { construc- } \\
\text { tion date }\end{array}$ & $\begin{array}{l}\text { Date of } \\
\text { sampling } \\
\text { (month/ } \\
\text { day/year) }\end{array}$ & $\begin{array}{c}\text { Land- } \\
\text { surface } \\
\text { elevation } \\
\text { (feet } \\
\text { above } \\
\text { NAVD 88) }\end{array}$ & $\begin{array}{c}\text { Depth } \\
\text { of well } \\
\text { (feet } \\
\text { below } \\
\text { land } \\
\text { surface) }\end{array}$ \\
\hline $\begin{array}{l}\text { Farson Sandstone-Alkali } \\
\text { Creek aquifer (Farson } \\
\text { Sandstone Member of the } \\
\text { Green River Formation) }\end{array}$ & Sublette & 424301109322501 & S5 & P6442P & $12 / 31 / 1949$ & 1949 & $8 / 17 / 2010$ & 7,190 & 75 \\
\hline $\begin{array}{l}\text { Farson Sandstone-Alkali } \\
\text { Creek aquifer (Farson } \\
\text { Sandstone Member of the } \\
\text { Green River Formation) }\end{array}$ & Sublette & 424442109440501 & S9 & P114520W & 3/11/1999 & 6/20/1999 & $8 / 16 / 2010$ & 6,970 & 65 \\
\hline $\begin{array}{l}\text { Farson Sandstone-Alkali } \\
\text { Creek aquifer (Farson } \\
\text { Sandstone Member of the } \\
\text { Green River Formation) }\end{array}$ & Sublette & 425101109481201 & SUB18 & P35241W & 8/9/1976 & 8/26/1976 & 9/20/2011 & 7,241 & 89 \\
\hline $\begin{array}{l}\text { Farson Sandstone-Alkali } \\
\text { Creek aquifer (Farson } \\
\text { Sandstone Member of the } \\
\text { Green River Formation) }\end{array}$ & Sublette & 425606109570801 & S6 & P6799P & 7/31/1947 & 1947 & $8 / 18 / 2010$ & 7,310 & 56 \\
\hline Lance aquifer & Goshen & 414907104155401 & W12 & P20984P & 3/21/1955 & 1955 & $8 / 24 / 2011$ & 4,320 & 100 \\
\hline Lance aquifer & Goshen & 414940104183001 & GOS11 & P16536P & 12/31/1929 & 1929 & 8/23/2011 & 4,363 & 100 \\
\hline Casper aquifer & Albany & 412439105360801 & ALB8 & P24708W & 10/17/1973 & 12/27/1973 & 8/28/2012 & 7,154 & 150 \\
\hline $\begin{array}{l}\text { Casper aquifer (Fountain } \\
\text { Formation) }\end{array}$ & Albany & 410715106002701 & ALB9 & P123410W & $2 / 15 / 2000$ & 3/16/2001 & 8/29/2012 & 7,456 & 90 \\
\hline Hartville aquifer & Platte & 422816105015701 & PLA13 & P316G & $12 / 8 / 1954$ & 7/2/1953 & 7/9/2012 & 4,626 & 435 \\
\hline Precambrian aquifer & Albany & 410039105374401 & ALB4 & P145304W & $6 / 18 / 2002$ & $10 / 18 / 2002$ & 8/14/2012 & 8,712 & 300 \\
\hline Precambrian aquifer & Albany & 410217106100001 & ALB12 & P195888W & 6/6/2011 & 7/7/2011 & 9/11/2012 & 9,145 & 120 \\
\hline Precambrian aquifer & Albany & 410821105234201 & ALB10 & P195528W & $4 / 18 / 2011$ & $6 / 23 / 2011$ & 9/10/2012 & 8,285 & 80 \\
\hline Precambrian aquifer & Albany & 413705105301801 & ALB2 & P185395W & 2/29/2008 & $9 / 22 / 2008$ & 8/13/2012 & 7,736 & 140 \\
\hline Precambrian aquifer & Albany & 420405105190901 & ALB18 & P151915W & 6/10/2003 & -- & 9/26/2012 & 6,183 & 19.8 \\
\hline Precambrian aquifer & Albany & 422014105203801 & ALB6 & P92306W & 7/16/1993 & $5 / 15 / 1994$ & 9/10/2012 & 6,356 & 100 \\
\hline Precambrian aquifer & Platte & 420025105132301 & PLA8 & P155333W & $12 / 4 / 2003$ & $7 / 29 / 2004$ & $6 / 25 / 2012$ & 4,955 & 225 \\
\hline
\end{tabular}




\begin{tabular}{|c|c|c|c|c|c|c|c|c|}
\hline $\begin{array}{l}\text { Hydrogeologic } \\
\text { unit }\end{array}$ & County & $\begin{array}{l}\text { U.S. Geological } \\
\text { Survey site } \\
\text { identification } \\
\text { number }\end{array}$ & $\begin{array}{c}\text { Water } \\
\text { level } \\
\text { (feet } \\
\text { below } \\
\text { land } \\
\text { surface) }\end{array}$ & $\begin{array}{l}\text { Screened or } \\
\text { open interval } \\
\text { (feet below } \\
\text { land surface) }\end{array}$ & $\begin{array}{l}\text { Casing } \\
\text { mate- } \\
\text { rial in } \\
\text { screened } \\
\text { interval }\end{array}$ & $\begin{array}{l}\text { Diam- } \\
\text { eter of } \\
\text { casing in } \\
\text { screened } \\
\text { interval } \\
\text { (inches) }\end{array}$ & $\begin{array}{l}\text { Casing } \\
\text { material } \\
\text { above } \\
\text { screened } \\
\text { or open } \\
\text { interval }\end{array}$ & $\begin{array}{l}\text { Diameter of } \\
\text { casing above } \\
\text { screened or } \\
\text { open interval } \\
\text { (inches) }\end{array}$ \\
\hline $\begin{array}{l}\text { Farson Sandstone-Alkali } \\
\text { Creek aquifer (Farson } \\
\text { Sandstone Member of the } \\
\text { Green River Formation) }\end{array}$ & Sublette & 424301109322501 & $14 \mathrm{P}$ & -- & -- & -- & $\mathrm{S}$ & 6 \\
\hline $\begin{array}{l}\text { Farson Sandstone-Alkali } \\
\text { Creek aquifer (Farson } \\
\text { Sandstone Member of the } \\
\text { Green River Formation) }\end{array}$ & Sublette & 424442109440501 & 8.75 & $45-65$ & PVC & 4.5 & $\mathrm{~S}$ & 6 \\
\hline $\begin{array}{l}\text { Farson Sandstone-Alkali } \\
\text { Creek aquifer (Farson } \\
\text { Sandstone Member of the } \\
\text { Green River Formation) }\end{array}$ & Sublette & 425101109481201 & 38.45 & $70-88$ & $\mathrm{~S}$ & 5.5 & $\mathrm{~S}$ & 6.625 \\
\hline $\begin{array}{l}\text { Farson Sandstone-Alkali } \\
\text { Creek aquifer (Farson } \\
\text { Sandstone Member of the } \\
\text { Green River Formation) }\end{array}$ & Sublette & 425606109570801 & $12.00 \mathrm{P}$ & -- & -- & -- & G & 6 \\
\hline Lance aquifer & Goshen & 414907104155401 & $30 \mathrm{P}$ & $40-100$ & $\mathrm{~S}$ & 6 & $\mathrm{~S}$ & 6 \\
\hline Lance aquifer & Goshen & 414940104183001 & 26.73 & -- & -- & -- & I & 6 \\
\hline Casper aquifer & Albany & 412439105360801 & 40.49 & $\begin{array}{l}110-120 \\
140-150\end{array}$ & PVC & 5 & $\mathrm{~S}$ & 6.625 \\
\hline $\begin{array}{l}\text { Casper aquifer (Fountain } \\
\text { Formation) }\end{array}$ & Albany & 410715106002701 & $47 \mathrm{P}$ & $50-90$ & PVC & 4 & PVC & 4 \\
\hline Hartville aquifer & Platte & 422816105015701 & $-6 \mathrm{P}$ & -- & -- & -- & $\mathrm{S}$ & 9 \\
\hline Precambrian aquifer & Albany & 410039105374401 & 16.22 & $240-300$ & PVC & 4.5 & PVC & 4.5 \\
\hline Precambrian aquifer & Albany & 410217106100001 & 5.98 & $\begin{array}{c}60-80 \\
100-120\end{array}$ & PVC & 4 & PVC & 4 \\
\hline Precambrian aquifer & Albany & 410821105234201 & 51.13 & $45-80$ & PVC & 4 & PVC & 4 \\
\hline Precambrian aquifer & Albany & 413705105301801 & 23.14 & $120-140$ & PVC & 4 & PVC & 4 \\
\hline Precambrian aquifer & Albany & 420405105190901 & 5.42 & -- & -- & -- & PVC & 5 \\
\hline Precambrian aquifer & Albany & 422014105203801 & 44.12 & $80-100$ & PVC & 4.5 & PVC & 4.5 \\
\hline Precambrian aquifer & Platte & 420025105132301 & 20.43 & $40-225$ & None & None & PVC & 6 \\
\hline
\end{tabular}


Table 4. Wyoming Groundwater-Quality Monitoring Network constituent list, analytical laboratory, analysis method, and method reference.

[USGS, U.S. Geological Survey; NWQL, U.S. Geological Survey National Water Quality Laboratory; EPA, U.S. Environmental Protection Agency Region VIII Laboratory; AA, atomic absorption; ICP, inductively-coupled plasma; MS, mass spectrometry; GFAA, graphic furnace atomic absorption; UV, ultraviolet; GC, gas chromatography; GC/MS, gas chromatography/mass spectrometry]

\begin{tabular}{|c|c|c|c|c|}
\hline $\begin{array}{l}\text { Constituent or } \\
\text { constituent group }\end{array}$ & $\begin{array}{l}\text { USGS laboratory } \\
\text { schedule (LS), USGS } \\
\text { laboratory code (LC), or } \\
\text { TestAmerica contract } \\
\text { item number (CIN) }\end{array}$ & $\begin{array}{l}\text { Laboratory or } \\
\text { personnel } \\
\text { conducting } \\
\text { analysis }\end{array}$ & Analysis method & Method reference \\
\hline \multicolumn{5}{|c|}{ Standard constituents } \\
\hline Alkalinity (dissolved) & LC2109 & $\begin{array}{l}\text { Wyoming Water Science } \\
\text { Center/NWQL }\end{array}$ & Fixed endpoint method & Fishman and Friedman (1989). \\
\hline Major ions (dissolved) & LS 1 & EPA/NWQL & $\begin{array}{l}\text { AA spectrometry, colorimetry, ion-exchange } \\
\text { chromatography, ICP atomic emission } \\
\text { spectrometry, and MS }\end{array}$ & $\begin{array}{l}\text { American Public Health Association (2005); Fishman } \\
\text { and Friedman (1989); Fishman (1993). }\end{array}$ \\
\hline Major ions (total) & LS 2294 & EPA/NWQL & $\begin{array}{l}\text { AA spectrometry, colorimetry, ion-exchange } \\
\text { chromatography, ICP atomic emission } \\
\text { spectrometry, and MS }\end{array}$ & $\begin{array}{l}\text { American Public Health Association (2005); Fishman } \\
\text { and Friedman (1989); Fishman (1993). }\end{array}$ \\
\hline $\begin{array}{l}\text { Dissolved solids (dis- } \\
\text { solved) }\end{array}$ & LC 27 & NWQL & $\begin{array}{l}\text { Solids, residue on evaporation at } 180 \text { degrees } \\
\text { Celsius, dissolved, gravimetric (total dis- } \\
\text { solved solids) }\end{array}$ & $\begin{array}{l}\text { American Public Health Association (2005); Fishman } \\
\text { and Friedman (1989). }\end{array}$ \\
\hline $\begin{array}{l}\text { Trace elements (dis- } \\
\text { solved) }\end{array}$ & LS2710 & EPA/NWQL & ICP MS and GFAA & $\begin{array}{l}\text { American Public Health Association (2005); Fish- } \\
\text { man and Friedman (1989); Faires (1993); McLain } \\
\text { (1993); American Public Health Association } \\
\text { (2005); Garbarino (1999); Jones and Garbarino } \\
\text { (1999). }\end{array}$ \\
\hline Trace elements (total) & LS 2296 & EPA/NWQL & ICP MS and GFAA & $\begin{array}{l}\text { American Public Health Association (2005); Fish- } \\
\text { man and Friedman (1989); Faires (1993); McLain } \\
\text { (1993); American Public Health Association } \\
\text { (2005); Garbarino (1999); Jones and Garbarino } \\
\text { (1999). }\end{array}$ \\
\hline Nutrients (dissolved) & LS 2752 & EPA/NWQL & Colorimetry & $\begin{array}{l}\text { American Public Health Association (2005); Fishman } \\
\text { (1993). }\end{array}$ \\
\hline Nutrients (total) & LS 2295 & EPA / NWQL & Colorimetry & $\begin{array}{l}\text { American Public Health Association (2005); Fishman } \\
\text { (1993). }\end{array}$ \\
\hline $\begin{array}{l}\text { Dissolved organic carbon } \\
\quad \text { (dissolved) }\end{array}$ & LC 2612 & NWQL & $\begin{array}{l}\text { UV-light promoted persulfate oxidation and } \\
\text { infrared spectrometry }\end{array}$ & Brenton and Arnett (1993). \\
\hline $\begin{array}{l}\text { Stable-isotope ratios of } \\
\text { hydrogen }\left(\delta^{2} \mathrm{H}\right) \text { and } \\
\text { oxygen }\left(\delta^{18} \mathrm{O}\right) \text { (total) }\end{array}$ & LS1142 & $\begin{array}{l}\text { Reston Stable Isotope } \\
\text { Laboratory }\end{array}$ & $\begin{array}{l}\text { Hydrogen equilibrium and carbon dioxide } \\
\text { equilibrium }\end{array}$ & $\begin{array}{l}\text { Coplen and others (1991); Epstein and Mayeda } \\
\text { (1953). }\end{array}$ \\
\hline $\begin{array}{l}\text { Volatile organic com- } \\
\text { pounds (total) }\end{array}$ & LS2020 & EPA/NWQL & Purge and trap-capillary-column GC/MS & Connor and others (1998). \\
\hline
\end{tabular}


Table 4. Wyoming Groundwater-Quality Monitoring Network constituent list, analytical laboratory, analysis method, and method reference.-Continued

[USGS, U.S. Geological Survey; NWQL, U.S. Geological Survey National Water Quality Laboratory; EPA, U.S. Environmental Protection Agency Region VIII Laboratory; AA, atomic absorption; ICP, inductively-coupled plasma; MS, mass spectrometry; GFAA, graphic furnace atomic absorption; UV, ultraviolet; GC, gas chromatography; GC/MS, gas chromatography/mass spectrometry]

\begin{tabular}{|c|c|c|c|c|}
\hline $\begin{array}{c}\text { Constituent or } \\
\text { constituent group }\end{array}$ & $\begin{array}{l}\text { USGS laboratory } \\
\text { schedule (LS), USGS } \\
\text { laboratory code (LC), or } \\
\text { TestAmerica contract } \\
\text { item number (CIN) }\end{array}$ & $\begin{array}{l}\text { Laboratory or } \\
\text { personnel } \\
\text { conducting } \\
\text { analysis }\end{array}$ & Analysis method & Method reference \\
\hline $\begin{array}{l}\text { Total coliform and Esch- } \\
\text { erichia coli bacteria } \\
\text { (total) }\end{array}$ & & $\begin{array}{l}\text { Wyoming Water Science } \\
\text { Center }\end{array}$ & m-Coliblue24C membrane filtration & U.S. Geological Survey (variously dated). \\
\hline \multicolumn{5}{|c|}{ Supplemental constituents } \\
\hline $\begin{array}{l}\text { Gross-alpha and gross- } \\
\text { beta radioactivity } \\
\text { (dissolved) }\end{array}$ & LS 1679 & Eberline Services & Evaporation & U.S. Environmental Protection Agency (1980). ${ }^{1}$ \\
\hline Radon-222 (total) & LC 1369 & NWQL & Liquid scintillation & American Society for Testing and Materials (1996). \\
\hline Tritium (total) & LC 1565 & $\begin{array}{l}\text { USGS Isotope Tracers } \\
\text { Project Laboratory }\end{array}$ & Electrolytic enrichment & Ostlund and Dorsey (1975). \\
\hline $\begin{array}{l}\text { Gasoline Range Organics } \\
\text { (total) }\end{array}$ & CIN 50134 & $\begin{array}{l}\text { EPA/TestAmerica } \\
\text { Laboratory }\end{array}$ & GC headspace equilibration technique & U.S Environmental Protection Agency (2004b). \\
\hline $\begin{array}{l}\text { Diesel Range Organics } \\
\text { (total) }\end{array}$ & CIN 50130 & $\begin{array}{l}\text { EPA/TestAmerica } \\
\text { Laboratory }\end{array}$ & GC headspace equilibration technique & U.S Environmental Protection Agency (2004b). \\
\hline $\begin{array}{l}\text { Dissolved hydrocarbon } \\
\text { gases (total) }\end{array}$ & CIN 50131 & $\begin{array}{l}\text { EPA/TestAmerica } \\
\text { Laboratory }\end{array}$ & GC headspace equilibration technique & U.S Environmental Protection Agency (2004b). \\
\hline $\begin{array}{l}\text { Wastewater compounds } \\
\text { (dissolved) }\end{array}$ & LS1433 & NWQL & $\begin{array}{l}\text { Polystyrene-divinylbenzene solid-phase } \\
\text { extraction and capillary-column GC/MS }\end{array}$ & Zaugg and others (2007). \\
\hline
\end{tabular}

${ }^{1}$ Gross-alpha activities were based on a thorium-230 curve and gross-beta activities were based on a cesium-137 curve. 
Table 5. Statistical summaries of groundwater-quality characteristics and constituents related to U.S. Environmental Protection Agency and Wyoming Department of Environmental Quality standards for samples from wells in the Wyoming Groundwater-Quality Monitoring Network, November 2009 through September 2012.

[USGS, U.S. Geological Survey; NWIS, National Water Information System; five-digit number in the USGS NWIS parameter code column is used to uniquely identify a specific constituent or property; MRL, minimum reporting level; ${ }^{\circ} \mathrm{C}$, degrees Celsius; --, not applicable; SMCL, Secondary Maximum Contaminant Level; $\mu \mathrm{S} / \mathrm{cm}$, microsiemens per centimeter at $25{ }^{\circ} \mathrm{C}$; mg/L, milligrams per liter; CaCO calcium carbonate; $\mathrm{CO}_{3}$, carbonate; <, less than; $\mathrm{HCO}_{3}$, bicarbonate; NTRU, nephelometric turbidity ratio units; MCL, Maximum Contaminant Level; AL, action level; HAL, health advisory level; E, estimated concentration; C, carbon; pCi/L, picocuries per liter; \pm , plus or minus; csu, 1-sigma combined standard uncertainty; R, values less than the sample-specific critical level are reported as nondetections; mRem/yr, millirems per year; PMCL, proposed Maximum Contaminant Level; AMCL, proposed alternate maximum contaminant Level; $\mu \mathrm{g} / \mathrm{L}$, micrograms per liter; MCLG, Maximum Contaminant Level Goal]

\begin{tabular}{|c|c|c|c|c|c|c|c|c|c|c|c|c|c|c|c|}
\hline \multirow[b]{2}{*}{ Constituent } & \multirow[b]{2}{*}{$\begin{array}{c}\text { Number } \\
\text { of detec- } \\
\text { tions/ } \\
\text { number } \\
\text { of } \\
\text { samples }\end{array}$} & \multirow[b]{2}{*}{$\begin{array}{c}\text { USGS } \\
\text { NWIS } \\
\text { param- } \\
\text { eter } \\
\text { code }\end{array}$} & \multirow[b]{2}{*}{$\begin{array}{l}\text { Highest } \\
\text { MRL }\end{array}$} & \multirow[b]{2}{*}{$\begin{array}{l}\text { Lowest } \\
\text { MRL }\end{array}$} & \multirow[b]{2}{*}{$\begin{array}{l}\text { Mini- } \\
\text { mum }\end{array}$} & \multirow[b]{2}{*}{$\begin{array}{l}\text { 25th } \\
\text { percen- } \\
\text { tile }\end{array}$} & \multirow[b]{2}{*}{ Median } & \multirow[b]{2}{*}{$\begin{array}{l}\text { 75th } \\
\text { percen- } \\
\text { tile }\end{array}$} & \multirow[b]{2}{*}{ Maximum } & \multirow{2}{*}{$\begin{array}{l}\text { U.S. Environ- } \\
\text { mental Protec- } \\
\text { tion Agency } \\
\text { drinking water } \\
\text { standards or } \\
\text { health advi- } \\
\text { sories (U.S. } \\
\text { Environmental } \\
\text { Protection } \\
\text { Agency, 2013a) }\end{array}$} & \multicolumn{5}{|c|}{$\begin{array}{l}\text { State of Wyoming groundwater-quality standards } \\
\text { (Wyoming Department of Environmental Quality, } \\
\text { 2005) }\end{array}$} \\
\hline & & & & & & & & & & & $\begin{array}{l}\text { Class I } \\
\text { domestic }\end{array}$ & $\begin{array}{l}\text { Class II } \\
\text { agricul- } \\
\text { ture }\end{array}$ & $\begin{array}{l}\text { Class III } \\
\text { livestock }\end{array}$ & $\begin{array}{l}\text { Class IV } \\
\text { industry }\end{array}$ & $\begin{array}{l}\text { Class } \\
\text { special } \\
\text { (A) fish } \\
\text { and } \\
\text { aquatic } \\
\text { life }\end{array}$ \\
\hline \multicolumn{16}{|c|}{ Physical characteristics measured onsite } \\
\hline Water temperature $\left({ }^{\circ} \mathrm{C}\right)$ & $146 / 146$ & 00010 & -- & -- & 5.5 & 9.98 & 12.2 & 13.8 & 18.4 & -- & -- & -- & -- & -- & -- \\
\hline $\begin{array}{l}\mathrm{pH}, \text { field (standard } \\
\text { units }\end{array}$ & $146 / 146$ & 00400 & -- & -- & 6.2 & 7.2 & 7.4 & 7.7 & 9.6 & $6.5-8.5$ (SMCL) & $6.5-8.5$ & $4.5-9.0$ & $6.5-8.5$ & -- & $6.5-9.0$ \\
\hline $\begin{array}{l}\text { Specific conductance } \\
\quad(\mu \mathrm{S} / \mathrm{cm})\end{array}$ & $146 / 146$ & 00095 & -- & -- & 53.7 & 368 & 497 & 844 & 17,300 & -- & -- & -- & -- & -- & -- \\
\hline $\begin{array}{l}\text { Dissolved oxygen } \\
\text { (mg/L) }\end{array}$ & $146 / 146$ & 00300 & -- & -- & 0.05 & 0.22 & 3.41 & 7.53 & 10.3 & -- & -- & -- & -- & -- & -- \\
\hline $\begin{array}{l}\text { Oxidation reduction } \\
\text { potential (relative } \\
\text { to the standard } \\
\text { hydrogen electrode, } \\
\text { millivolts) }\end{array}$ & $146 / 146$ & 63002 & -- & -- & -269 & 44.9 & 104 & 162 & 374 & -- & -- & -- & -- & -- & -- \\
\hline $\begin{array}{l}\text { Alkalinity, field }(\mathrm{mg} / \mathrm{L} \\
\left.\text { as } \mathrm{CaCO}_{3}\right)\end{array}$ & $146 / 146$ & 39086 & -- & -- & 14.3 & 137 & 180 & 254 & 1,090 & -- & -- & -- & -- & -- & -- \\
\hline $\begin{array}{l}\text { Carbonate }(\mathrm{mg} / \mathrm{L} \text { as } \\
\left.\mathrm{CO}_{3}\right)\end{array}$ & $146 / 146$ & 00452 & -- & -- & $<0.1$ & 0.30 & 0.40 & 0.625 & 34.8 & -- & -- & -- & -- & -- & -- \\
\hline $\begin{array}{l}\text { Bicarbonate }(\mathrm{mg} / \mathrm{L} \text { as } \\
\left.\mathrm{HCO}_{3}\right)\end{array}$ & $146 / 146$ & 00453 & -- & -- & 17.3 & 166 & 214 & 305 & 1,310 & -- & -- & -- & -- & -- & -- \\
\hline Turbidity (NTRU) & $146 / 146$ & 63676 & -- & -- & 0.11 & 0.30 & 0.60 & 1.60 & 346 & 5.0 (SMCL) & -- & -- & -- & -- & -- \\
\hline \multicolumn{16}{|c|}{ Major ions and related water-quality characteristics, in milligrams per liter (dissolved, sample filtered through 0.45-micrometer filter) } \\
\hline Calcium & $146 / 146$ & 00915 & 0.100 & 0.044 & 0.86 & 29.7 & 48.6 & 73.5 & 533 & & -- & -- & -- & -- & -- \\
\hline Magnesium & $145 / 146$ & 00925 & 0.100 & 0.016 & $<0.10$ & ${ }^{1} 5.06$ & ${ }^{1} 11.2$ & ${ }^{1} 21.2$ & 1,200 & -- & -- & -- & -- & -- & -- \\
\hline Sodium & $146 / 146$ & 00930 & 0.500 & 0.10 & 1.66 & 13.8 & 39.3 & 89.2 & 3,270 & -- & -- & -- & -- & -- & -- \\
\hline
\end{tabular}


Table 5. Statistical summaries of groundwater-quality characteristics and constituents related to U.S. Environmental Protection Agency and Wyoming Department of Environmental Quality standards for samples from wells in the Wyoming Groundwater-Quality Monitoring Network, November 2009 through September 2012.-Continued

[USGS, U.S. Geological Survey; NWIS, National Water Information System; five-digit number in the USGS NWIS parameter code column is used to uniquely identify a specific constituent or property; MRL, minimum reporting level; ${ }^{\circ} \mathrm{C}$, degrees Celsius; --, not applicable; SMCL, Secondary Maximum Contaminant Level; $\mu \mathrm{S} / \mathrm{cm}$, microsiemens per centimeter at $25{ }^{\circ} \mathrm{C}$; mg/L, milligrams per liter; CaCO ${ }_{3}$, calcium carbonate; $\mathrm{CO}_{3}$, carbonate; <, less than; $\mathrm{HCO}_{3}$, bicarbonate; NTRU, nephelometric turbidity ratio units; MCL, Maximum Contaminant Level; AL, action level; $\mathrm{HAL}$, health advisory level; E, estimated concentration; $\mathrm{C}$, carbon; $\mathrm{pCi} / \mathrm{L}$, picocuries per liter; \pm , plus or minus; csu, 1-sigma combined standard uncertainty; R, values less than the sample-specific critical level are reported as nondetections; $\mathrm{mRem} / \mathrm{yr}$, millirems per year; PMCL, proposed Maximum Contaminant Level; AMCL, proposed alternate maximum contaminant Level; $\mu \mathrm{g} / \mathrm{L}$, micrograms per liter; MCLG, Maximum Contaminant Level Goal]

\begin{tabular}{|c|c|c|c|c|c|c|c|c|c|c|c|c|c|c|c|}
\hline \multirow[b]{2}{*}{ Constituent } & \multirow{2}{*}{$\begin{array}{c}\text { Number } \\
\text { of detec- } \\
\text { tions/ } \\
\text { number } \\
\text { of } \\
\text { samples }\end{array}$} & \multirow[b]{2}{*}{$\begin{array}{l}\text { USGS } \\
\text { NWIS } \\
\text { param- } \\
\text { eter } \\
\text { code }\end{array}$} & \multirow[b]{2}{*}{$\begin{array}{l}\text { Highest } \\
\text { MRL }\end{array}$} & \multirow[b]{2}{*}{$\begin{array}{l}\text { Lowest } \\
\text { MRL }\end{array}$} & \multirow[b]{2}{*}{$\begin{array}{l}\text { Mini- } \\
\text { mum }\end{array}$} & \multirow[b]{2}{*}{$\begin{array}{l}\text { 25th } \\
\text { percen- } \\
\text { tile }\end{array}$} & \multirow[b]{2}{*}{ Median } & \multirow[b]{2}{*}{$\begin{array}{l}\text { 75th } \\
\text { percen- } \\
\text { tile }\end{array}$} & \multirow[b]{2}{*}{ Maximum } & \multirow{2}{*}{$\begin{array}{l}\text { U.S. Environ- } \\
\text { mental Protec- } \\
\text { tion Agency } \\
\text { drinking water } \\
\text { standards or } \\
\text { health advi- } \\
\text { sories (U.S. } \\
\text { Environmental } \\
\text { Protection } \\
\text { Agency, 2013a) }\end{array}$} & \multicolumn{5}{|c|}{$\begin{array}{l}\text { State of Wyoming groundwater-quality standards } \\
\text { (Wyoming Department of Environmental Quality, } \\
\text { 2005) }\end{array}$} \\
\hline & & & & & & & & & & & $\begin{array}{c}\text { Class I } \\
\text { domestic }\end{array}$ & $\begin{array}{l}\text { Class II } \\
\text { agricul- } \\
\text { ture }\end{array}$ & $\begin{array}{l}\text { Class III } \\
\text { livestock }\end{array}$ & $\begin{array}{l}\text { Class IV } \\
\text { industry }\end{array}$ & $\begin{array}{l}\text { Class } \\
\text { special } \\
\text { (A) fish } \\
\text { and } \\
\text { aquatic } \\
\text { life }\end{array}$ \\
\hline Potassium & $127 / 146$ & 00935 & 1.00 & 0.064 & $<1.00$ & ${ }^{1} 1.69$ & 14.49 & ${ }^{1} 6.24$ & 53.5 & -- & -- & -- & -- & -- & -- \\
\hline Chloride & $136 / 140$ & 00940 & 0.5 & 0.12 & $<0.5$ & 2.9 & 8.60 & 19.8 & 1,960 & 250 (SMCL) & 250 & 100 & 2,000 & -- & -- \\
\hline Sulfate & $140 / 140$ & 00945 & 0.50 & 0.18 & 2.30 & 12.7 & 37.3 & 155 & 8,790 & 250 (SMCL) & 250 & 200 & 3,000 & -- & -- \\
\hline Fluoride & $121 / 140$ & 00950 & 1 & 0.08 & 0.13 & ${ }^{1} 0.3$ & ${ }^{1} 0.50$ & ${ }^{1} 0.7$ & 3.87 & $\begin{array}{l}4.0 \text { (MCL); } 2.0 \\
\quad \text { (SMCL) }\end{array}$ & 4 & -- & -- & -- & -- \\
\hline Silica & $146 / 146$ & 00955 & 4.0 & 0.2 & 4.63 & 9.96 & 20.9 & 48.0 & 69.8 & -- & -- & -- & -- & -- & -- \\
\hline Dissolved solids & $146 / 146$ & 70300 & 20 & 10 & 40.8 & 242 & 340 & 584 & 17,600 & 500 (SMCL) & 500 & 2,000 & 5,000 & 10,000 & $\begin{array}{l}2500 \\
{ }^{3} 1,000 \\
{ }^{4} 2,000\end{array}$ \\
\hline \multicolumn{16}{|c|}{ Trace elements, in micrograms per liter (total) } \\
\hline Aluminum & $17 / 146$ & 01105 & 100 & 3.80 & $<3.80$ & ${ }^{1} 0.043$ & ${ }^{1} 0.504$ & 15.76 & 7,330 & 50-200 (SMCL) & -- & 5,000 & 5,000 & -- & 100 \\
\hline Barium & $142 / 146$ & 01007 & 4.00 & 0.60 & $<4.00$ & 32.0 & 63.0 & 97.2 & 416 & $2,000(\mathrm{MCL})$ & 2,000 & -- & -- & -- & 5,000 \\
\hline Beryllium & $1 / 146$ & 01012 & 1.00 & 0.02 & $<0.020$ & -- & -- & -- & 0.034 & 4 (MCL) & -- & 100 & -- & -- & $11-1,300$ \\
\hline Cadmium & $6 / 146$ & 01027 & 0.200 & 0.016 & $<0.016$ & -- & -- & -- & 0.775 & 5 (MCL) & 5 & 10 & 50 & -- & $0.4-15$ \\
\hline Chromium & $13 / 146$ & 01034 & 0.420 & 0.300 & $<0.300$ & ${ }^{1} 0.053$ & ${ }^{1} 0.162$ & ${ }^{1} 0.543$ & 16.5 & 100 (MCL) & 100 & 100 & 50 & -- & 50 \\
\hline Cobalt & $11 / 146$ & 01037 & 2.00 & 0.02 & $<0.020$ & ${ }^{1} 0.004$ & ${ }^{1} 0.018$ & ${ }^{10} 0.078$ & 2.64 & -- & -- & 50 & 1,000 & -- & -- \\
\hline Copper & $33 / 146$ & 01042 & 5.00 & 0.700 & $<0.700$ & ${ }^{1} 0.215$ & ${ }^{1} 0.860$ & ${ }^{1} 3.29$ & 535 & $\begin{array}{l}\text { 1,300 (AL); } \\
\text { 1,000 (SMCL) }\end{array}$ & 1,000 & 200 & 500 & -- & $10-40$ \\
\hline Iron & 28/136 & 01045 & 100 & 9.2 & 33.3 & 12.47 & ${ }^{1} 13.5$ & 173.6 & 11,200 & 300 (SMCL) & 300 & 5,000 & -- & -- & 500 \\
\hline Lead & $15 / 146$ & 01051 & 1.0 & 0.04 & E0.033 & ${ }^{1} 0.013$ & ${ }^{1} 0.042$ & ${ }^{1} 0.145$ & 4.8 & 300 (SMCL) & 15 & 5,000 & 100 & -- & $4-150$ \\
\hline Lithium & $17 / 17$ & 01132 & 0.30 & 0.30 & 4.29 & 22.2 & 30.1 & 42.8 & 602 & -- & -- & 2,500 & -- & -- & -- \\
\hline Manganese & 49/136 & 01055 & 2.0 & 0.50 & $<2.0$ & ${ }^{1} 0.055$ & ${ }^{1} 0.643$ & 18.52 & 2,770 & 50 (SMCL) & 50 & 200 & -- & -- & 1,000 \\
\hline
\end{tabular}


Table 5. Statistical summaries of groundwater-quality characteristics and constituents related to U.S. Environmental Protection Agency and Wyoming Department of Environmental Quality standards for samples from wells in the Wyoming Groundwater-Quality Monitoring Network, November 2009 through September 2012.-Continued

[USGS, U.S. Geological Survey; NWIS, National Water Information System; five-digit number in the USGS NWIS parameter code column is used to uniquely identify a specific constituent or property; MRL, minimum reporting level; ${ }^{\circ} \mathrm{C}$, degrees Celsius; --, not applicable; SMCL, Secondary Maximum Contaminant Level; $\mu \mathrm{S} / \mathrm{cm}$, microsiemens per centimeter at $25{ }^{\circ} \mathrm{C}$; mg/L, milligrams per liter; CaCO

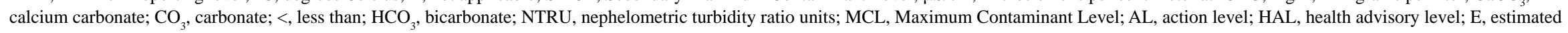
concentration; $\mathrm{C}$, carbon; $\mathrm{pCi} / \mathrm{L}$, picocuries per liter; \pm , plus or minus; csu, 1-sigma combined standard uncertainty; R, values less than the sample-specific critical level are reported as nondetections; mRem/yr, millirems per year; PMCL, proposed Maximum Contaminant Level; AMCL, proposed alternate maximum contaminant Level; $\mu \mathrm{g} / \mathrm{L}$, micrograms per liter; MCLG, Maximum Contaminant Level Goal]

\begin{tabular}{|c|c|c|c|c|c|c|c|c|c|c|c|c|c|c|c|}
\hline \multirow[b]{2}{*}{ Constituent } & \multirow[b]{2}{*}{$\begin{array}{c}\text { Number } \\
\text { of detec- } \\
\text { tions/ } \\
\text { number } \\
\text { of } \\
\text { samples }\end{array}$} & \multirow[b]{2}{*}{$\begin{array}{c}\text { USGS } \\
\text { NWIS } \\
\text { param- } \\
\text { eter } \\
\text { code }\end{array}$} & \multirow[b]{2}{*}{$\begin{array}{c}\text { Highest } \\
\text { MRL }\end{array}$} & \multirow[b]{2}{*}{$\begin{array}{c}\text { Lowest } \\
\text { MRL }\end{array}$} & \multirow[b]{2}{*}{$\begin{array}{l}\text { Mini- } \\
\text { mum }\end{array}$} & \multirow[b]{2}{*}{$\begin{array}{l}\text { 25th } \\
\text { percen- } \\
\text { tile }\end{array}$} & \multirow[b]{2}{*}{ Median } & \multirow[b]{2}{*}{$\begin{array}{l}\text { 75th } \\
\text { percen- } \\
\text { tile }\end{array}$} & \multirow[b]{2}{*}{ Maximum } & \multirow{2}{*}{$\begin{array}{l}\text { U.S. Environ- } \\
\text { mental Protec- } \\
\text { tion Agency } \\
\text { drinking water } \\
\text { standards or } \\
\text { health advi- } \\
\text { sories (U.S. } \\
\text { Environmental } \\
\text { Protection } \\
\text { Agency, 2013a) }\end{array}$} & \multicolumn{5}{|c|}{$\begin{array}{l}\text { State of Wyoming groundwater-quality standards } \\
\text { (Wyoming Department of Environmental Quality, } \\
\text { 2005) }\end{array}$} \\
\hline & & & & & & & & & & & $\begin{array}{c}\text { Class I } \\
\text { domestic }\end{array}$ & $\begin{array}{l}\text { Class II } \\
\text { agricul- } \\
\text { ture }\end{array}$ & $\begin{array}{l}\text { Class III } \\
\text { livestock }\end{array}$ & $\begin{array}{l}\text { Class IV } \\
\text { industry }\end{array}$ & $\begin{array}{l}\text { Class } \\
\text { special } \\
\text { (A) fish } \\
\text { and } \\
\text { aquatic } \\
\text { life }\end{array}$ \\
\hline Molybdenum & $82 / 146$ & 01062 & 5.0 & 0.1 & $<5.0$ & ${ }^{1} 2.31$ & ${ }^{1} 4.22$ & 17.52 & 341 & 40 (HAL) & -- & -- & -- & -- & -- \\
\hline Nickel & $15 / 146$ & 01067 & 4.0 & 0.19 & $<0.19$ & ${ }^{1} 0.047$ & ${ }^{1} 0.191$ & ${ }^{1} 0.656$ & 35.8 & 100 (HAL) & -- & 200 & -- & -- & $50-400$ \\
\hline Silver & $6 / 146$ & 01077 & 0.5 & 0.015 & $<0.015$ & -- & -- & -- & E2.10 & $\begin{array}{l}100 \text { (HAL/ } \\
\text { SMCL) }\end{array}$ & 100 & -- & -- & -- & $0.1-0.25$ \\
\hline Strontium & $146 / 146$ & 01082 & 2.0 & 0.6 & 19.8 & 246 & 435 & 685 & 12,900 & 4,000 (HAL) & -- & -- & -- & -- & -- \\
\hline Thallium & $21 / 146$ & 01059 & 0.3 & 0.06 & $<0.06$ & ${ }^{1} 0.067$ & ${ }^{1} 0.126$ & ${ }^{1} 0.240$ & E1.60 & 2 (MCL) & -- & -- & -- & -- & -- \\
\hline Vanadium & $50 / 146$ & 01087 & 10 & 1.6 & $<10$ & 12.34 & 14.94 & ${ }^{1} 10.98$ & 84.7 & -- & -- & 100 & 100 & -- & -- \\
\hline Zinc & $12 / 146$ & 01092 & 50 & 2 & $<2.0$ & ${ }^{1} 1.16$ & ${ }^{13} .03$ & 17.29 & 178 & $\begin{array}{l}\text { 2,000 (HAL); } \\
\text { 5,000 (SMCL) }\end{array}$ & 5,000 & 2,000 & 25,000 & -- & $50-600$ \\
\hline Antimony & $3 / 146$ & 01097 & 1.0 & 0.18 & $<0.18$ & -- & -- & -- & 1.3 & 6 (MCL, HAL) & -- & -- & -- & -- & -- \\
\hline Arsenic & $41 / 146$ & 01002 & 4.0 & 0.18 & $<4.0$ & ${ }^{1} 0.994$ & ${ }^{1} 1.94$ & ${ }^{1} 3.87$ & 32.7 & 10 (MCL) & 50 & 100 & 200 & -- & 50 \\
\hline Boron & $67 / 146$ & 01022 & 100 & 4.8 & 32.4 & ${ }^{1} 40.3$ & ${ }^{1} 81.5$ & ${ }^{1} 154$ & 6,610 & 6,000 (HAL) & 750 & 750 & 5,000 & -- & -- \\
\hline Selenium & $78 / 146$ & 01147 & 1.0 & 0.10 & $<0.10$ & ${ }^{1} 0.214$ & ${ }^{1} 0.909$ & ${ }^{1} 2.50$ & E207 & 50 (MCL, HAL) & 50 & 20 & 50 & -- & 50 \\
\hline \multicolumn{16}{|c|}{ Nutrients and dissolved organic carbon, in milligrams per liter (dissolved, sample filtered through 0.45-micrometer filter) } \\
\hline Ammonia, as nitrogen & $13 / 140$ & 00608 & 0.050 & 0.010 & $<0.010$ & ${ }^{1} 0.002$ & ${ }^{1} 0.005$ & ${ }^{1} 0.019$ & 0.405 & -- & 5,000 & -- & -- & -- & 200 \\
\hline Nitrite, as nitrogen & $15 / 140$ & 00613 & 0.02 & 0.001 & $<0.001$ & -- & -- & -- & 1.20 & 1.0 (MCL) & 1.0 & -- & 10 & -- & -- \\
\hline Nitrate, as nitrogen & $127 / 140$ & 00618 & 0.04 & 0.005 & $<0.005$ & ${ }^{1} 0.080$ & ${ }^{1} 1.35$ & 13.53 & 63.5 & 10 (MCL) & 10 & -- & -- & -- & -- \\
\hline $\begin{array}{l}\text { Orthophosphate, as } \\
\text { phosphorus }\end{array}$ & $114 / 140$ & 00671 & 0.01 & 0.005 & $<0.005$ & ${ }^{1} 0.014$ & ${ }^{1} 0.045$ & ${ }^{1} 0.134$ & 1.50 & -- & -- & -- & -- & -- & -- \\
\hline $\begin{array}{c}\text { Dissolved organic car- } \\
\text { bon (in mg/L as C) }\end{array}$ & $143 / 146$ & 00681 & 0.23 & 0.15 & $<0.15$ & 0.635 & 1.43 & 2.24 & 67.4 & -- & -- & -- & -- & -- & -- \\
\hline
\end{tabular}


Table 5. Statistical summaries of groundwater-quality characteristics and constituents related to U.S. Environmental Protection Agency and Wyoming Department of Environmental Quality standards for samples from wells in the Wyoming Groundwater-Quality Monitoring Network, November 2009 through September 2012.-Continued

[USGS, U.S. Geological Survey; NWIS, National Water Information System; five-digit number in the USGS NWIS parameter code column is used to uniquely identify a specific constituent or property; MRL, minimum reporting level; ${ }^{\circ} \mathrm{C}$, degrees Celsius; --, not applicable; SMCL, Secondary Maximum Contaminant Level; $\mu \mathrm{S} / \mathrm{cm}$, microsiemens per centimeter at $25{ }^{\circ} \mathrm{C}$; mg/L, milligrams per liter; CaCO ${ }_{3}$, calcium carbonate; $\mathrm{CO}_{3}$, carbonate; <, less than; $\mathrm{HCO}_{3}$, bicarbonate; NTRU, nephelometric turbidity ratio units; MCL, Maximum Contaminant Level; AL, action level; $\mathrm{HAL}$, health advisory level; E, estimated concentration; $\mathrm{C}$, carbon; $\mathrm{pCi} / \mathrm{L}$, picocuries per liter; \pm , plus or minus; csu, 1-sigma combined standard uncertainty; $\mathrm{R}$, values less than the sample-specific critical level are reported as nondetections; $\mathrm{mRem} / \mathrm{y}$, millirems per year; PMCL, proposed Maximum Contaminant Level; AMCL, proposed alternate maximum contaminant Level; $\mu \mathrm{g} / \mathrm{L}$, micrograms per liter; MCLG, Maximum Contaminant Level Goal]

\begin{tabular}{|c|c|c|c|c|c|c|c|c|c|c|c|c|c|c|c|}
\hline \multirow[b]{2}{*}{ Constituent } & \multirow[b]{2}{*}{$\begin{array}{c}\text { Number } \\
\text { of detec- } \\
\text { tions/ } \\
\text { number } \\
\text { of } \\
\text { samples }\end{array}$} & \multirow[b]{2}{*}{$\begin{array}{l}\text { USGS } \\
\text { NWIS } \\
\text { param- } \\
\text { eter } \\
\text { code }\end{array}$} & \multirow[b]{2}{*}{$\begin{array}{l}\text { Highest } \\
\text { MRL }\end{array}$} & \multirow[b]{2}{*}{$\begin{array}{l}\text { Lowest } \\
\text { MRL }\end{array}$} & \multirow[b]{2}{*}{$\begin{array}{l}\text { Mini- } \\
\text { mum }\end{array}$} & \multirow[b]{2}{*}{$\begin{array}{l}\text { 25th } \\
\text { percen- } \\
\text { tile }\end{array}$} & \multirow[b]{2}{*}{ Median } & \multirow[b]{2}{*}{$\begin{array}{l}\text { 75th } \\
\text { percen- } \\
\text { tile }\end{array}$} & \multirow[b]{2}{*}{ Maximum } & \multirow{2}{*}{$\begin{array}{l}\text { U.S. Environ- } \\
\text { mental Protec- } \\
\text { tion Agency } \\
\text { drinking water } \\
\text { standards or } \\
\text { health advi- } \\
\text { sories (U.S. } \\
\text { Environmental } \\
\text { Protection } \\
\text { Agency, 2013a) }\end{array}$} & \multicolumn{5}{|c|}{$\begin{array}{l}\text { State of Wyoming groundwater-quality standards } \\
\text { (Wyoming Department of Environmental Quality, } \\
\text { 2005) }\end{array}$} \\
\hline & & & & & & & & & & & $\begin{array}{l}\text { Class I } \\
\text { domestic }\end{array}$ & $\begin{array}{l}\text { Class II } \\
\text { agricul- } \\
\text { ture }\end{array}$ & $\begin{array}{l}\text { Class III } \\
\text { livestock }\end{array}$ & $\begin{array}{l}\text { Class IV } \\
\text { industry }\end{array}$ & $\begin{array}{l}\text { Class } \\
\text { special } \\
\text { (A) fish } \\
\text { and } \\
\text { aquatic } \\
\text { life }\end{array}$ \\
\hline \multicolumn{16}{|c|}{ Radionuclides, in picocuries per liter (total unless otherwise noted) } \\
\hline $\begin{array}{l}\text { Gross alpha radioac- } \\
\text { tivity (dissolved) } \\
(\mathrm{pCi} / \mathrm{L} \pm \mathrm{csu})\end{array}$ & $10 / 12$ & 04126 & -- & -- & $\begin{array}{c}1.05 \pm \\
0.71\end{array}$ & 1.52 & 4.35 & 6.48 & $136 \pm 22$ & 515 (MCL) & ${ }^{6} 15$ & ${ }^{6} 15$ & ${ }^{6} 15$ & -- & ${ }^{6} 15$ \\
\hline $\begin{array}{l}\text { Gross beta radioactiv- } \\
\text { ity (dissolved) }\end{array}$ & $11 / 12$ & 3515 & -- & -- & $\begin{array}{l}\mathrm{R} 0.604 \\
\pm 0.55\end{array}$ & 1.35 & 3.90 & 23.7 & $74.6 \pm 9.0$ & $\begin{array}{l}4 \mathrm{mRem} / \mathrm{yr} \\
(\mathrm{MCL})\end{array}$ & -- & -- & -- & -- & -- \\
\hline Radon (pCi/L \pm csu) & $13 / 14$ & 82303 & -- & -- & $\begin{array}{c}\mathrm{R} 8.9 \pm \\
8.3\end{array}$ & 536 & 670 & 845 & $\begin{array}{c}3,620 \pm \\
200\end{array}$ & $\begin{array}{l}300 \text { (PMCL); } \\
\quad 4,000 \\
\quad(\text { AMCL) }\end{array}$ & -- & -- & -- & -- & -- \\
\hline Uranium, total $(\mu \mathrm{g} / \mathrm{L})$ & $138 / 146$ & 28011 & 0.2 & 0.028 & $<0.10$ & ${ }^{1} 1.66$ & ${ }^{17.25}$ & ${ }^{1} 18.0$ & 209 & 30 g/L (MCL) & 15 & 15 & 15 & -- & $\begin{array}{c}30-1,400 \\
\mu \mathrm{g} / \mathrm{L}\end{array}$ \\
\hline \multicolumn{16}{|c|}{ Environmental isotopes (hydrogen and oxygen, in per mil relative to Vienna Standard Mean Ocean Water and tritium, in picocuries per liter) (total) } \\
\hline $\begin{array}{l}\text { Deuterium/protium } \\
\text { isotopic ratio }\end{array}$ & 146/146 & 82082 & -- & -- & -158 & -128 & -115 & -107 & -84.6 & -- & -- & -- & -- & -- & -- \\
\hline $\begin{array}{l}\text { Oxygen-18/oxygen-16 } \\
\text { isotopic ratio }\end{array}$ & $146 / 146$ & 82085 & -- & -- & -20.3 & -16.7 & -14.9 & -13.6 & -8.50 & -- & -- & -- & -- & -- & -- \\
\hline Tritium (pCi/L \pm csu) & $17 / 18$ & 07000 & -- & -- & $\begin{array}{c}\mathrm{R} 0.08 \pm \\
0.38\end{array}$ & 3.64 & 22.8 & 27.0 & $39.2 \pm 1.3$ & -- & -- & -- & -- & -- & -- \\
\hline
\end{tabular}

\begin{tabular}{|c|c|c|c|c|c|c|c|c|c|c|c|c|c|c|c|}
\hline \multicolumn{16}{|c|}{ Organic compounds, in micrograms per liter Volatile organic compounds, gasoline range and diesel range organics, and dissolved hydrocarbon gases(total) } \\
\hline Benzene & $1 / 145$ & 34030 & 0.50 & 0.026 & $<0.026$ & -- & -- & -- & E0.018 & 5.0 (MCL) & -- & -- & -- & -- & -- \\
\hline Toluene & $4 / 146$ & 34010 & 0.50 & 0.02 & $<0.02$ & -- & -- & -- & 9.8 & 1,000 (MCL) & -- & -- & -- & -- & -- \\
\hline Ethylbenzene & $1 / 146$ & 34371 & 0.25 & 0.036 & $<0.036$ & -- & -- & -- & E0.32 & 700 (MCL) & -- & -- & -- & -- & -- \\
\hline$m$ - and $p$-Xylene & $1 / 146$ & 85795 & 1.0 & 0.08 & $<0.08$ & -- & -- & -- & E0.02 & $\begin{array}{l}\text { 10,000 (MCL for } \\
\text { total xylenes) }\end{array}$ & -- & -- & -- & -- & -- \\
\hline
\end{tabular}


Table 5. Statistical summaries of groundwater-quality characteristics and constituents related to U.S. Environmental Protection Agency and Wyoming Department of Environmental Quality standards for samples from wells in the Wyoming Groundwater-Quality Monitoring Network, November 2009 through September 2012.-Continued

[USGS, U.S. Geological Survey; NWIS, National Water Information System; five-digit number in the USGS NWIS parameter code column is used to uniquely identify a specific constituent or property; MRL, minimum reporting level; ${ }^{\circ} \mathrm{C}$, degrees Celsius; --, not applicable; SMCL, Secondary Maximum Contaminant Level; $\mu \mathrm{S} / \mathrm{cm}$, microsiemens per centimeter at $25{ }^{\circ} \mathrm{C}$; mg/L, milligrams per liter; CaCO calcium carbonate; $\mathrm{CO}_{3}$, carbonate; <, less than; $\mathrm{HCO}_{3}$, bicarbonate; NTRU, nephelometric turbidity ratio units; MCL, Maximum Contaminant Level; AL, action level; $\mathrm{HAL}$, health advisory level; E, estimated concentration; C, carbon; pCi/L, picocuries per liter; \pm , plus or minus; csu, 1-sigma combined standard uncertainty; R, values less than the sample-specific critical level are reported as nondetections; mRem/yr, millirems per year; PMCL, proposed Maximum Contaminant Level; AMCL, proposed alternate maximum contaminant Level; $\mu \mathrm{g} / \mathrm{L}$, micrograms per liter; MCLG, Maximum Contaminant Level Goal]

\begin{tabular}{|c|c|c|c|c|c|c|c|c|c|c|c|c|c|c|c|}
\hline \multirow[b]{2}{*}{ Constituent } & \multirow[b]{2}{*}{$\begin{array}{c}\text { Number } \\
\text { of detec- } \\
\text { tions/ } \\
\text { number } \\
\text { of } \\
\text { samples }\end{array}$} & \multirow[b]{2}{*}{$\begin{array}{c}\text { USGS } \\
\text { NWIS } \\
\text { param- } \\
\text { eter } \\
\text { code }\end{array}$} & \multirow[b]{2}{*}{$\begin{array}{c}\text { Highest } \\
\text { MRL }\end{array}$} & \multirow[b]{2}{*}{$\begin{array}{l}\text { Lowest } \\
\text { MRL }\end{array}$} & \multirow[b]{2}{*}{$\begin{array}{l}\text { Mini- } \\
\text { mum }\end{array}$} & \multirow[b]{2}{*}{$\begin{array}{l}\text { 25th } \\
\text { percen- } \\
\text { tile }\end{array}$} & \multirow[b]{2}{*}{ Median } & \multirow[b]{2}{*}{$\begin{array}{l}\text { 75th } \\
\text { percen- } \\
\text { tile }\end{array}$} & \multirow[b]{2}{*}{ Maximum } & \multirow{2}{*}{$\begin{array}{l}\text { U.S. Environ- } \\
\text { mental Protec- } \\
\text { tion Agency } \\
\text { drinking water } \\
\text { standards or } \\
\text { health advi- } \\
\text { sories (U.S. } \\
\text { Environmental } \\
\text { Protection } \\
\text { Agency, 2013a) }\end{array}$} & \multicolumn{5}{|c|}{$\begin{array}{l}\text { State of Wyoming groundwater-quality standards } \\
\text { (Wyoming Department of Environmental Quality, } \\
\text { 2005) }\end{array}$} \\
\hline & & & & & & & & & & & $\begin{array}{l}\text { Class I } \\
\text { domestic }\end{array}$ & $\begin{array}{l}\text { Class II } \\
\text { agricul- } \\
\text { ture }\end{array}$ & $\begin{array}{l}\text { Class III } \\
\text { livestock }\end{array}$ & $\begin{array}{l}\text { Class IV } \\
\text { industry }\end{array}$ & $\begin{array}{l}\text { Class } \\
\text { special } \\
\text { (A) fish } \\
\text { and } \\
\text { aquatic } \\
\text { life }\end{array}$ \\
\hline o-Xylene & $0 / 146$ & 77135 & 0.50 & 0.032 & -- & -- & -- & -- & -- & $\begin{array}{l}\text { 10,000 (MCL for } \\
\text { total xylenes) }\end{array}$ & -- & -- & -- & -- & -- \\
\hline $\begin{array}{l}\text { Gasoline range organ- } \\
\text { ics }\end{array}$ & 9/116 & 49892 & 20 & 4.0 & $<4.0$ & ${ }^{12.62}$ & ${ }^{1} 4.47$ & ${ }^{17.46}$ & 27 & -- & -- & -- & -- & -- & -- \\
\hline $\begin{array}{l}\text { Diesel range organics } \\
(\mathrm{mg} / \mathrm{L})\end{array}$ & $45 / 116$ & 63746 & 0.25 & 0.020 & $<0.020$ & ${ }^{1} 0.011$ & ${ }^{1} 0.016$ & ${ }^{1} 0.026$ & ${ }^{7} 0.140$ & -- & -- & -- & -- & -- & -- \\
\hline Methane & $26 / 116$ & 76994 & 0.22 & 0.22 & $<0.22$ & ${ }^{1} 0.002$ & ${ }^{1} 0.018$ & ${ }^{1} 0.197$ & 220 & -- & -- & -- & -- & -- & -- \\
\hline Ethene & $1 / 116$ & 82044 & 5.0 & 0.40 & $<0.40$ & -- & -- & -- & E1.60 & -- & -- & -- & -- & -- & -- \\
\hline Ethane & $1 / 116$ & 82045 & 5.0 & 0.24 & $<0.24$ & -- & -- & -- & E1.70 & -- & -- & -- & -- & -- & -- \\
\hline \multicolumn{16}{|c|}{ Wastewater compounds, in micrograms per liter (dissolved, sample filtered through a 0.70-micrometer filter) } \\
\hline $\begin{array}{l}N, N \text {-diethyl-meta-tolu- } \\
\text { amide (DEET) }\end{array}$ & $17 / 43$ & 62082 & 0.06 & 0.06 & $<0.06$ & ${ }^{1} 0.010$ & ${ }^{1} 0.018$ & ${ }^{1} 0.030$ & E0.12 & -- & -- & -- & -- & -- & -- \\
\hline Benzophenone & $13 / 43$ & 62067 & 0.08 & 0.08 & $<0.08$ & ${ }^{1} 0.014$ & ${ }^{1} 0.017$ & ${ }^{1} 0.023$ & 0.03 & -- & -- & -- & -- & -- & -- \\
\hline Phenanthrene & $18 / 43$ & 34462 & 0.016 & 0.016 & $<0.016$ & ${ }^{1} 0.005$ & ${ }^{1} 0.008$ & ${ }^{1} 0.012$ & ${ }^{7} \mathrm{E} 0.030$ & -- & -- & -- & -- & -- & -- \\
\hline \multicolumn{16}{|c|}{ Coliform bacteria, in colonies per 100 milliliters (total) } \\
\hline Total coliform & $60 / 141$ & 90900 & 1 & 1 & $<1$ & $<1$ & ${ }^{1<1}$ & 13 & E111 & 0 (MCLG) & -- & -- & -- & -- & -- \\
\hline Escherichia coli & $2 / 141$ & 90901 & 1 & 1 & $<1$ & -- & -- & -- & E3 & 0 (MCLG) & -- & -- & -- & -- & -- \\
\hline
\end{tabular}

${ }^{1}$ Value is estimated by using a log-probability regression to predict the values of data below the detection limit.

${ }^{2}$ Egg hatching.

${ }^{3}$ Fish rearing.

${ }^{4}$ Fish and aquatic life.

${ }^{5}$ Not including radon or uranium.

${ }^{6}$ Including radium-226 but excluding radon and uranium.

${ }^{7}$ Quantified concentration in the environmental sample is less than five times the maximum concentration in a blank sample. 
Table 6. Dissolved-solids concentrations in waters from hydrogeologic units compared to U.S. Geological Survey salinity classification (Heath, 1983) for samples from wells sampled for the Wyoming Groundwater-Quality Monitoring Network, November 2009 through September 2012.

\begin{tabular}{|c|c|c|c|c|c|}
\hline \multirow[b]{2}{*}{ Number of samples } & \multicolumn{5}{|c|}{$\begin{array}{l}\text { Dissolved-solids range, in milligrams per liter; and } \\
\text { U.S. Geological Survey salinity classification }\end{array}$} \\
\hline & $\begin{array}{l}\text { Less than } \\
\text { 1,000; fresh }\end{array}$ & $\begin{array}{l}1,000 \text { to less } \\
\text { than 3,000; } \\
\text { slightly saline }\end{array}$ & $\begin{array}{c}3,000 \text { to less } \\
\text { than 10,000; } \\
\text { moderately saline }\end{array}$ & $\begin{array}{l}10,000 \text { to less } \\
\text { than } 35,000 ; \\
\text { very saline }\end{array}$ & $\begin{array}{c}\text { More than } \\
\text { 35,000; } \\
\text { briny }\end{array}$ \\
\hline Quaternary unconsolidated-deposit aquifers & 36 & 1 & 2 & 2 & 0 \\
\hline Ogallala aquifer & 10 & 0 & 0 & 0 & 0 \\
\hline Arikaree aquifer & 22 & 0 & 0 & 0 & 0 \\
\hline $\begin{array}{l}\text { White River Group (White River, Brule and Chadron } \\
\text { aquifers) }\end{array}$ & 28 & 1 & 0 & 0 & 0 \\
\hline Bridger aquifer & 2 & 0 & 0 & 0 & 0 \\
\hline $\begin{array}{l}\text { Wasatch zone of the Wasatch-Fort Union aquifer } \\
\text { (Wasatch aquifer) }\end{array}$ & 17 & 1 & 0 & 0 & 0 \\
\hline Farson Sandstone-Alkali Creek aquifer & 6 & 0 & 0 & 0 & 0 \\
\hline Lance aquifer & 2 & 1 & 0 & 0 & 0 \\
\hline Sundance aquifer & 0 & 1 & 0 & 0 & 0 \\
\hline Nugget aquifer & 1 & 0 & 0 & 0 & 0 \\
\hline Casper aquifer & 4 & 1 & 0 & 0 & 0 \\
\hline Hartville aquifer & 1 & 0 & 0 & 0 & 0 \\
\hline Precambrian aquifer & 7 & 0 & 0 & 0 & 0 \\
\hline
\end{tabular}



Appendix 


\section{Appendix}

Table 1-1. Quality-control data for groundwater samples collected for the Wyoming Groundwater-Quality Monitoring Network, November 2009 through September 2012.

Table 1-2. Analyses for physical characteristics measured in groundwater samples collected for the Wyoming Groundwater-Quality Monitoring Network, November 2009 through September 2012.

Table 1-3. Analyses for major ions measured in groundwater samples collected for the Wyoming Groundwater-Quality Monitoring Network, November 2009 through September 2012.

Table 1-4. Analyses for trace elements measured in groundwater samples collected for the Wyoming Groundwater-Quality Monitoring Network, November 2009 through September 2012.

Table 1-5. Analyses for nutrients and dissolved organic carbon measured in groundwater samples collected for the Wyoming Groundwater-Quality Monitoring Network, November 2009 through September 2012.

Table 1-6. Analyses for radionuclides and environmental isotopes measured in groundwater samples collected for the Wyoming Groundwater-Quality Monitoring Network, November 2009 through September 2012.

Table 1-7. Analyses for organic compounds (volatile organic compounds, gasoline range and diesel range organics, and dissolved hydrocarbon gases) measured in groundwater samples collected for the Wyoming Groundwater-Quality Monitoring Network, November 2009 through September 2012.

Table 1-8. Analyses for organic compounds (wastewater compounds) measured in groundwater samples collected for the Wyoming Groundwater-Quality Monitoring Network, November 2009 through September 2012.

Table 1-9. Analyses for bacteria measured in groundwater samples collected for the Wyoming Groundwater-Quality Monitoring Network, November 2009 through September 2012. 
Publishing support provided by Rolla and Lafayette Publishing Service Centers

Director, Wyoming-Montana Water Science Center U.S. Geological Survey 3162 Bozeman Ave Helena, MT 59601 (406) 457-5900 http://wy-mt.water.usgs.gov/ 

